FRANK JACOB (ED.)

\title{
ENGELS @ 200
}

Reading Friedrich Engels in the 21st Century

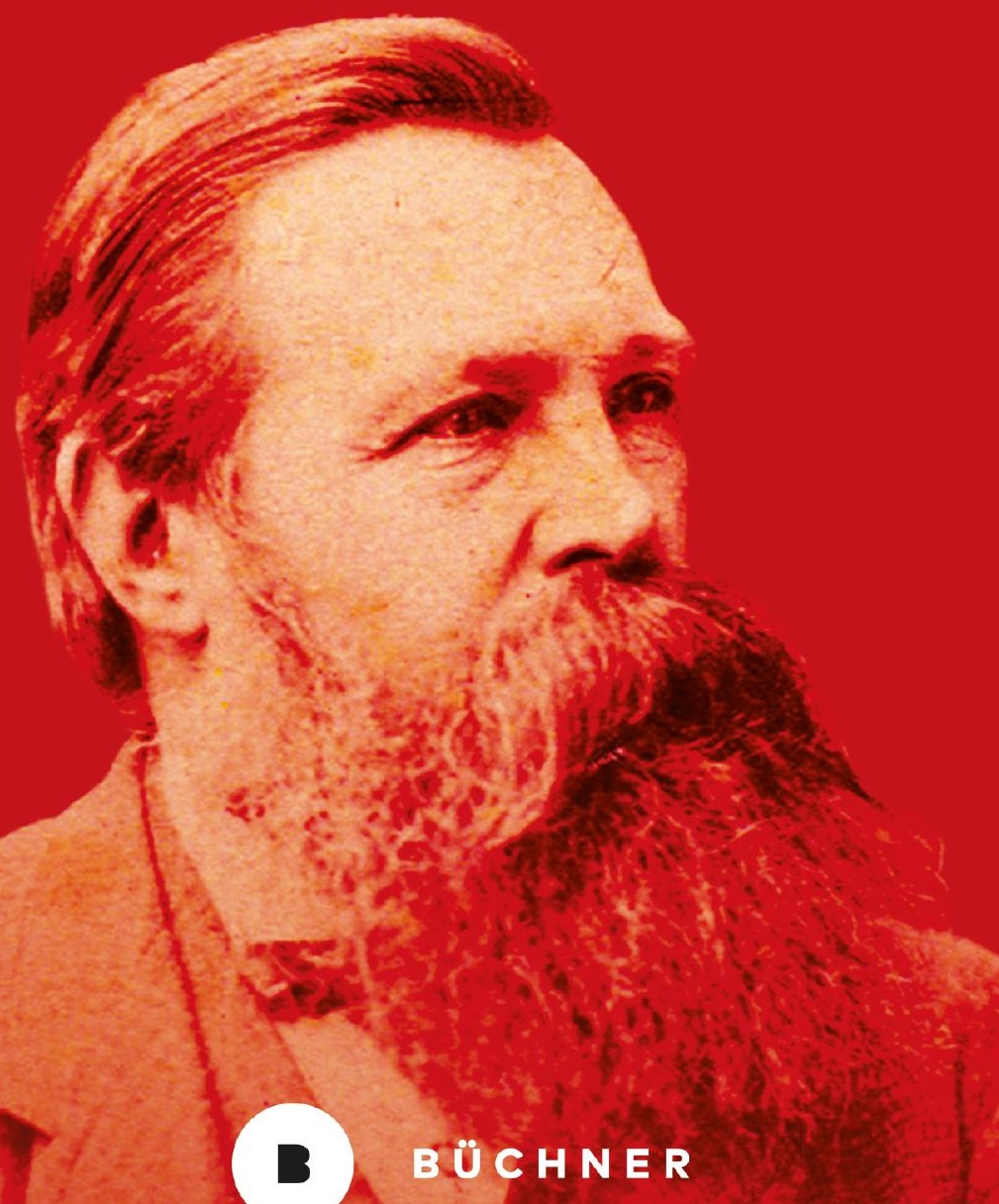


Engels@200 



\section{Frank Jacob (Ed.) \\ Engels @ 200}

\section{Reading Friedrich Engels in the 2Ist Century}


Frank Jacob (Ed.)

Engels@200

Reading Friedrich Engels in the 2Ist Century

ISBN (Print) 978-3-96317-225-0

ISBN (ePDF) 978-3-96317-762-0

DOI I0.I463I/978-3-96317-762-0

Erschienen 2020 bei: Büchner-Verlag eG, Marburg

Satz: SatzHerstellung Verlagsdienstleistungen Heike Amthor, Fernwald

Umschlaggestaltung: DeinSatz Marburg | If

Bildnachweis Umschlag: Porträt Friedrich Engels, I879;

Wikimedia Commons: https://commons.wikimedia.org/wiki/

File:Friedrich_Engels_portrait.jpg (bearbeitet)

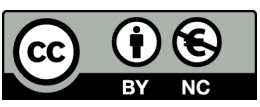

Dieses Werk erscheint unter der Creative-Commons-Lizenz

CC BY-NC 4.o: https://creativecommons.org/licenses/by-nc/4.o/.

Die Bedingungen der Creative-Commons-Lizenz gelten nur für

Originalmaterial. Die Wiederverwendung von Material aus anderen Quellen (gekennzeichnet mit Quellenangabe) wie z. B. Schaubilder,

Abbildungen, Fotos und Textauszüge erfordert ggf. weitere

Nutzungsgenehmigungen durch den jeweiligen Rechteinhaber.

Printausgabe:

Druck und Bindung: Schaltungsdienst Lange oHG, Berlin

Die verwendeten Druckmaterialien sind zertifiziert als FSC-Mix.

Printed in Germany

Bibliografische Informationen der Deutschen Nationalbibliothek Die Deutsche Nationalbibliothek verzeichnet diese Publikation in der

Deutschen Nationalbibliografie, detaillierte bibliografische Angaben sind im Internet über http://dnb.de abrufbar.

www.buechner-verlag.de 


\section{Contents}

Engels @ 200: An Introduction

Frank Jacob ............................. 7

Notes on Dialectics and History in Friedrich Engels

Vitor Bartoletti Sartori ......................... 25

Friedrich Engels and Revolution Theory:

The Legacy of a Revolutionary Life

Frank Jacob

The Gens, Military Conquest, and the Formation of the Manchu State: Understanding the Pre-State Manchu Society from an Engelsian Perspective (1550-1651)

Jia Feng.................................

The Contribution of Engels to the Critique of Political Economy

Renildo Souza ................................ 127

The Psychology of Friedrich Engels:

From Materialistic Theories of Manual Labor

to Criticism of Empiricism and Ideology

David Pavón-Cuéllar ............................. 157 
Engels and Evolutionist Ethnology

Maria Rosário de Carvalho . . . . . . . . . . . . . . . . . . . . . 173

Friedrich Engels's Philosophy of Nature.

An Interpretation of the Concept

of the Dialectics of Nature

Gotffried Schweiger

The Relationship between Art and Politics:

On the Letter of Friedrich Engels

to Margaret Harkness

Henrique Wellen . .

Friedrich Engels: From the ,Woman Question،

to Social Reproduction Theory

Vincent Streichbahn ........................... 235

In the Shadow of Karl Marx: Perception and Reception of Friedrich Engels in the Digital Age

Riccardo Altieri ........................... 271

Post-Truth Coronavirus Outbreak:

Engels's Perspective

Nuruddin Al Akbar . . . . . . . . . . . . . . . . . . . . . . . . . 289

Engels as Course Reading in the 21st Century History Classroom

Alexander Maxwell

Contributors ............................ 353 


\title{
Engels @ 200: An Introduction
}

\author{
Frank Jacob
}

I would always say "Engels and Marx." The big rabbit was ... Engels. ${ }^{1}$

Paul Frölich (I884-1953), ${ }^{2}$ a founding member of the German Communist Party, recognized the importance of Friedrich Engels in this quote, which he sent as a remark related to a manuscript ${ }^{3}$ by the Ukrainian Marxist Roman Rosdolsky (I898-1967). ${ }^{4}$ In contrast to Frölich's view, however, Engels continued to be seen as the second fiddle ${ }^{5}$ and is often neglected with regard to his role and influence on the course of the history in general and Marxism in particular. Engels, as German historian Jürgen Herres put it, was a "republi-

I Letter by Paul Frölich to Roman Rosdolsky, Kew Gardens, New York, October 26, 1948, International Institute of Social History, Amsterdam, Rosdolsky Papers 6, Correspondence with Paul and Rosi Frölich I948 to I950, 3. I would like to thank Riccardo Altieri for pointing me towards this source.

2 Riccardo Altieri, "Paul Frölich, American Exile, and Communist Discourse about the Russian Revolution, "American Communist History I7, no. 2 (2018): S. 220-23I.

3 The manuscript was eventually not published before both, Frölich and Rosdolsky, were already dead. Roman Rosdolsky, Zur Entstehungsgeschichte des Marxschen Kapital (Frankfurt am Main/Vienna, 1968).

4 Janusz Radziejowski, »Roman Rosdolsky: Man, Activist and Scholar, "Science \& Society 42, no. 2 (1978): 198-210.

5 Georges Labica, "Friedrich Engels-Wissenschaftler und Revolutionär, in Zwischen Utopie und Kritik: Friedrich Engels—ein "Klassiker" nach roo Jahren, eds. Theodor Bergmann, Mario Keßler, Joost Kircz and Gert Schäfer (Hamburg: VSA, I996), I8. Engels called himself a "second violine" in a letter to Johann Philipp Becker, October 15, I884, in: Marx-Engels-Werke (Berlin: Dietz, 1956-, henceforth $M E W)$, 36: 218. 
can communist and a European social critic. $«^{6}$ Thomas Kuczynski in addition called him a "young genius of social science. $\|^{7}$ A quarter century after his death, an article in Der Wahre Jacob claimed Engels to be the "creator of eternal intellectual works" and, at the same time, a "pioneer of German and international socialism. " $^{8}$ Engels indeed was an intellectual giant, whose personality was so colorful and multifaceted that it is not easy to describe it accurately. ${ }^{9}$ Regardless of this fact, the number of biographies and works about Engels never became legion, as it did in the case of his friend Karl Marx (I8I8-I883). . ${ }^{\text {Io }}$ At the same time, however, Engels's work was much more diverse than the writings of Marx. ${ }^{\text {II }}$ He was, to name just one example here, not only a philosopher and a social scientist, but also a military historian, one who realized the importance of the techno-

6 Jürgen Herres, „Friedrich Engels: Republikanischer Kommunist und europäischer Gesellschaftskritiker, " in Friedrich Engels: Ein Gespenst geht um in Europa-Begleitband zur Engelsausstellung 2020, ed. Lars Bluma (Wuppertal: Historisches Zentrum Wuppertal, 2020), I6-29.

7 Thomas Kuczynski, "Die zweite Violine, in "Die Natur ist die Probe auf die Dialektik«: Friedrich Engels kennenlernen, eds. Elmar Altvater et al. (Hamburg: VSA Verlag, 2020), 27.

8 A. Conrady, "Friedrich Engels, "Beilage zum Wahren Jacob, No. 887, July 30, I920: 10027 .

9 Theodor Bergmann, Mario Keßler, Joost Kircz and Gert Schäfer, "Einleitung," in Zwischen Utopie und Kritik: Friedrich Engels—ein "Klassiker" nach roo Jahren, eds. Theodor Bergmann, Mario Keßler, Joost Kircz and Gert Schäfer (Hamburg: VSA, 1996), 9; Michael Krätke, "Friedrich Engels, der erste Marxist, « in Friedrich Engels oder: Wie ein "Cotton-Lord" den Marxismus erfand, ed. Michael Krätke (Berlin: Dietz, 2020), 58.

Io Some important biographies are Gustav Mayer, Friedrich Engels: Eine Biographie, 2 vols. (Berlin: Springer, 1920-1933); Hans Peter Bleuel, Friedrich Engels: Bürger und Revolutionär (Bern/Munich: Scherz, 198I); Tristram Hunt, Friedrich Engels: Der Mann, der den Marxismus erfand, transl. by Klaus-Dieter Schmidt, third edition (Berlin: List, 2020).

II Bergmann, et al. "Einleitung, " II; Conrady, „Friedrich Engels, « IOO27-IOO28; Marcel van der Linden, "Friedrich Engels's Herkunft und Lebensleistung: Eine biografische Skizze," in "Die Natur ist die Probe auf die Dialektik«: Friedrich Engels kennenlernen, eds. Elmar Altvater et al. (Hamburg: VSA Verlag, 2020), I9. 
logical development and identified the industrial-military context. ${ }^{12}$ Engels was consequently called a "pioneer of the revolutionary-socialist military theory ${ }^{13}$ as well, and one of his writings, "Po and Rhine« (I859), ${ }^{\text {I4 }}$ was initially considered to have been written by a member of the Prussian General Staff. is What already becomes clear from this short introduction here is that there is more to Engels than just his friendship with Marx that makes him an important intellectual of the igth century. Since he intellectually represented "a materialism of conditions and complex mediation, which determined the problems of scientific research for him, $\varkappa^{16}$ is it not surprising that Engels got interested in other scientific fields during his life as well? While diving into all kinds of knowledge, he developed what Epifanio San Juan, Jr. called a "genius that was organized strategically." Engels's intelligence "aimed for practice " and therefore influenced all his research. ${ }^{17}$ It was, at the same time, very much influenced by his personal life, which is essential to understanding how the young Engels turned into a radical communist.

The German historian Gustav Mayer (I87I-1948), in his "groundbreaking work $\aleph^{18}$ on Engels's life, emphasized that no biography of any other important leaders of the political workers movement initially pointed so little to such a historical course. ${ }^{19}$ Born on 28 November 1820 in Barmen, nowadays part of Wuppertal, Engels was the eldest son of a cotton manufacturer by the same name and grew up in "a family of culture" in which "nothing pointed to his later

I2 Bergmann, et al. »Einleitung, « II.

I3 van der Linden, "Friedrich Engels's Herkunft, « I7.

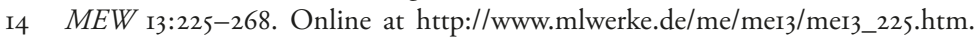
Accessed August 20, 2020.

I5 Kuczynski, »Die zweite Violine, «30.

I6 Epifanio San Juan, Jr., "Was wir aus Engels’s revolutionärer Ästhetik lernen können, " in Zwischen Utopie und Kritik: Friedrich Engels—ein "Klassiker" nach 100 Jahren, eds. Theodor Bergmann, Mario Keßler, Joost Kircz and Gert Schäfer (Hamburg: VSA, 1996), 69.

I7 Ibid., 70.

I8 Hunt, Friedrich Engels, I3.

I9 Mayer, Friedrich Engels, 4. 
revolutionary interest. $\aleph^{20}$ His early years were determined by »industry, trade, bourgeois duties, and loyalty to the family, ${ }^{21}$ and while Engels did not face any sorrows and was surrounded by »loving parents [and] indulgent grandparents, ${ }^{22}$ the boy would eventually suffer from "the pressure of religious, political, and social conventions. ${ }^{23} \mathrm{In}$ 1837, Engels had to leave school, as his father wanted him to become part of the family business, especially since the latter had decided to expand and invest in a joint venture with the Ermen brothers factory in Manchester. ${ }^{24}$ Following this decision, the young Engels's life changed, and from then onwards, he had to subordinate his own interests to the family business. ${ }^{25}$

After a year in the Barmen factory and a first trip to England with his father in the summer of I838, Engels was sent to Bremen, where he was supposed to continue his business education in a company where he oversaw exports and was responsible for international correspondence. Regardless of the fact that he had to work in a field he very much disliked, Engels, in contrast to Marx, was never melancholic or discouraged. ${ }^{26} \mathrm{He}$ was rather a radical romantic damned to a life in a trading post. ${ }^{27}$ After his time in Bremen, Engels served as a volunteer in the Prussian Guard Artillery Brigade in Berlin. ${ }^{28}$ While officially serving in the military, the young intellectual used his time in the metropolis to intensify his studies and visited lectures at the univer-

\footnotetext{
20 Hunt, Friedrich Engels, I9.

2 I Ibid., 22.

22 Ibid., I9.

23 Narihiko Ito, "Realismus und Utopismus, « in Zwischen Utopie und Kritik: Friedrich Engels - ein "Klassiker" nach Ioo Jahren, eds. Theodor Bergmann, Mario Keßler, Joost Kircz and Gert Schäfer (Hamburg: VSA, 1996), 23. On Engels's early years in Wuppertal see Reiner Rhefus, Friedrich Engels im Wuppertal: Auf den Spuren des Denkers, Machers und Revolutionärs im "deutschen Manchester" (Hamburg: VSA, 2020).

24 Hunt, Friedrich Engels, 38; van der Linden, „Friedrich Engels’s Herkunft, 8.

25 Krätke, »Friedrich Engels, « I5.

26 Ibid., I9.

27 Hunt, Friedrich Engels, 47.

28 Ibid., 64; van der Linden, „Friedrich Engels’s Herkunft, « IO.
} 
sity, where he got particularly interested in philosophy, especially the works of Georg Wilhelm Friedrich Hegel (1770-1831). ${ }^{29}$ The latter, although he had already been dead for a decade, would always remain an wauthority of the history of science ${ }^{30}$ for Engels, who considered philosophy to be the root of German communism.

The young intellectual was consequently further radicalized in Berlin. In 1842, when he visited the editorial staff of the Rheinische Zeitung in Cologne, he met Marx for the first time. However, the beginning of their more intense cooperation had not yet developed. ${ }^{3 \mathrm{I}}$ Instead, Engels spent time in England again-between November I842 and August I844-where, working as an assistant for the management at Ermen \& Engels, he began to understand the rules of modern capitalism. In his writings, which resemble those of an »elegant novelist, ${ }^{32}$ especially since Engels wrote much more lightly and clearly than Marx ${ }^{33}$ he criticized capitalism and its consequences for the working class early on. Already in I839, Engels had anonymously published some "Letters from Wuppertal «34 in which he had criticized pietism, Calvinism, and authentically described the bad condition of the workers in his home region. ${ }^{35}$ His time in England and his relationship with Mary Burns (I82I-I863), a factory worker, however, further radicalized Engels, and when he returned, he was dedicated to changing the fate of the working class. ${ }^{36}$ In 1845 he published his first major work, The Condition of the Working Class in England, ${ }^{37}$ in

29 Hunt, Friedrich Engels, 66; Ito, "Realismus und Utopismus, « 23.

30 Krätke, »Friedrich Engels, « 38 .

3I van der Linden, "Friedrich Engels's Herkunft, « II.

32 Hunt, Friedrich Engels, 50.

33 Kuczynski, "Die zweite Violine, « 32.

34 Telegraph für Deutschland, nos. 49, 50, 51, 52, 57 and 59 in March and April 1839. Online at https://www.marxists.org/archive/marx/works/I839/o3/telegraph.htm. Accessed Augsut 20, 2020.

35 Hunt, Friedrich Engels, 54; van der Linden, "Friedrich Engels’s Herkunft, " 9 .

36 Bergmann, et al. »Einleitung, « IO; van der Linden, »Friedrich Engels’s Herkunft, « I2.

37 For a more detailed discussion of the work see Regina Roth, ")Die Lage der arbeitenden Klasse in England von Engels im Spiegel ihrer Zeit (I845-I892), " in 
which he not only prophetically announced a near revolution ${ }^{38}$ but also provided an early study of empirical social research. The study is still considered today to be a "pioneer work «" ${ }^{39}$ in this field and "classic of urban sociology. « ${ }^{40}$

In August 1844, after his time in England, he met Marx again for ten days in Paris, where both intensively discussed their views and laid the foundation for their following and intensive cooperation. ${ }^{4 \mathrm{I}}$ In Marx, Engels had finally found somebody who understood him and did not have a problem with him being a "private scholar," having previously been criticized by academics and confronted with their classist views. ${ }^{42}$ Both intellectuals would be further influenced by historical events. While Engels had predicted a revolution in the early 1840 s that would happen in accordance with a theoretical model in relation to the French Revolution of $1789,{ }^{43}$ the reality would be a disappointment and demand some reflections about revolutionary processes as such. ${ }^{44}$ Engels had been actively involved in the revolution, first as a journalist and then as a barricade fighter, but he

Friedrich Engels: Ein Gespenst geht um in Europa-Begleitband zur Engelsausstellung 2020, ed. Lars Bluma (Wuppertal: Historisches Zentrum Wuppertal, 2020), 84-99.

38 Krätke, "Friedrich Engels, « 30 .

39 van der Linden, "Friedrich Engels's Herkunft, « I6.

40 Krätke, »Friedrich Engels, « 32.

4I van der Linden, „Friedrich Engels's Herkunft, « I3.

42 Krätke, »Friedrich Engels, « I9 and 23. That classism is still a problem in academia is discussed in some recent publications: Riccardo Altieri and Bernd Hüttner, eds. Klassismus und Wissenschaft. Erfahrungsberichte und Bewältigungsstrategien (Marburg: BdWi-Verlag, 2020) and Julia Reuter, Markus Gamper, Christina Möller and Frerk Blome, eds. Vom Arbeiterkind zur Professur: Sozialer Aufstieg in der Wissenschaft. Autobiographische Notizen und soziobiographische Analysen (Bielefeld: Transcript Verlag, 2020).

43 Ito, "Realismus und Utopismus, « 25.

44 For Engels's evaluation of the Revolution of I848, see Friedrich Engels, "Das Jahr I848 war das Jahr der Enttäuschung, I7.III.[I849], " IISH, Karl Marx/Friedrich Engels Papers, ARCHoo86o, H_8. 
could not change its historical course and had to witness its failure. ${ }^{45}$ The experience would, however, influence the further work of Marx and Engels, who tried to scientifically prepare another revolution in the future while their politics were determined by a »revolutionary reservation " (Revolutionsvorbehalt). ${ }^{46}$ Both consequently conceptualized the process of a revolution of the igth century in their work, and they made it clear that it would be important to have access to the full power of a purposeful party and an enlightened mass of the people to really secure the success of a future revolution. ${ }^{47}$ Engels, who considered history to be a process without any final or absolute truth, emphasized the role of crises in awakening the revolutionary potential of a particular time..$^{8}$ Engels's and Marx's reflections about revolutions, nevertheless, were consequently products of their own experiences of the 1840 and must be considered as such when taken into consideration today. ${ }^{49}$

What is important to understand is that Engels already realized in the 1840 os that a revolution was like an inevitable natural event, forced into being by pressure from suppressed people who demanded change. It could therefore not be made or planned by a small minority-as such revolutions would fail like the revolutions of $1848 / 49$ - but was the expression of a popular demand by the masses..$^{50}$ The failure of the revolution also meant an end for Engels's dream to leave the business world and to help with creating a new, better world..$^{\text {sI }}$ Due to his

45 Kuczynski, „Die zweite Violine, « 28; van der Linden, „Friedrich Engels’s Herkunft, «I6.

46 Georg Fülberth, Friedrich Engels (Cologne: PapyRossa, 2018), 68.

47 Ibid., 69.

48 Hunt, Friedrich Engels, 73; Krätke, »Friedrich Engels, « 28.

49 Marjan Britovšek, "Die slawischen Nationalbewegungen und die Perspektiven der Revolution, « in Zwischen Utopie und Kritik: Friedrich Engels—ein "Klassiker" nach Ioo Jahren, eds. Theodor Bergmann, Mario Keßler, Joost Kircz and Gert Schäfer (Hamburg: VSA, I996), I40.

50 Conrady, »Friedrich Engels, « IOO28.

5I Kuczynski, "Die zweite Violine, «28; Detlef Vonde, Aufden Barrikaden: Friedrich Engels und die "gescheiterte Revolution" von I848/49 (Wuppertal: Köndgen, 2019), 7-8. 
active role, he was forced into exile, "expatriated by the bourgeois revolution. ${ }^{5^{2}}$ In the following years, Engels tried to better understand what had happened in 1848 and therefore studied historical cases as well. His work on The Peasant War in Germany (1850) 53 was "a small but nice attempt to interpret the central European peasant rebellions of the I6th century in a materialist way. ${ }^{54}$ Regardless of these approaches and the wish to understand revolutions much better, Engels, like Marx as well, was not in favor of so-called revolutionaries by profession. ${ }^{5}$ In their works, the two men rather addressed questions of their times, which is why German political scientist Georg Fülberth correctly called them "operative intellectuals. ${ }^{56}$ Regardless of his many works, while in exile, Engels also had to work for the company of his father, which he could not leave before 1869 due to financial necessities; consequently, until then, he had to live a double life as a businessman and an intellectual.57 However, between 1870 and 1895 , he could focus on the latter. ${ }^{58}$ Regardless of his personal condition, Engels worked relentlessly to develop a socialist science, although he remained a passionate utopian at the same time. ${ }^{9}$ He remained a believer in revolution as the only way to achieve the final liberation of mankind, and in 1892 assumed that the socialist party would be in

52 Ibid., 8.

53 Friedrich Engels, "The Peasant War in Germany" (I850). Accessed August 20, 2020. https://www.marxists.org/archive/marx/works/1850/peasant-war-germany/ index.htm.

54 van der Linden, „Friedrich Engels’s Herkunft, « I8.

55 Krätke, »Friedrich Engels, " 59.

56 Fülberth, Friedrich Engels, I2.

57 Paul Lafargue, "Persönliche Erinnerungen, " in Friedrich Engels oder: Wie ein "Cotton-Lord" den Marxismus erfand, ed. Michael Krätke (Berlin: Dietz, 2020), I85; van der Linden, "Friedrich Engels's Herkunft, « I8. Engels had saved sufficient money for his later life, and when he died his fortune still counted for more than 30,000 Pounds (approximately more than 4 million Euro today).

58 Georg Fülberth, „Endlich angekommen: Friedrich Engels's Londoner Jahre 1870-1895," in Friedrich Engels: Ein Gespenst geht um in Europa-Begleitband zur Engelsausstellung 2020, ed. Lars Bluma (Wuppertal: Historisches Zentrum Wuppertal, 2020), 182-195.

59 Ito, "Realismus und Utopismus, « 32. 
power in the next decade. ${ }^{60}$ At the same time, however, he declared a year later that this was not the final goal for German socialism, as one would rather have to consider the socialists to be revolutionaries who were not intending to dictate the future of human society but wanted to achieve freedom for the masses so that they could decide this for themselves. ${ }^{61}$

The impact of the political ideas of Friedrich Engels is, at the same time, important to understand the development of his friend Karl Marx, ${ }^{62}$ as it was their friendship ${ }^{63}$ and intellectual cooperation that would be responsible for a new interpretation of human history and progress alike. The lives and works of the two friends eventually became so interwoven that it is quite challenging to separate them. ${ }^{64}$ However, Engels not only supported Marx intellectually, he also supported the latter and his family financially, and in I85I even accepted fatherhood for the child Marx had had with Helene Demuth, the family's maid, and thereby saved Marx's marriage. ${ }^{65}$ With regard to their intellectual cooperation, ${ }^{66}$ Engels played an equally important role, as both only seemed to accept each other as critics of their own

60 Friedrich Engels, "Interview mit dem Korrespondenten der Zeitung L'Éclair am I. April I892," in Friedrich Engels oder: Wie ein "Cotton-Lord" den Marxismus erfand, ed. Michael Krätke (Berlin: Dietz, 2020), 58.

6I Friedrich Engels, "Interview mit dem Korrespondenten der Zeitung Le Figaro am 8. Mai 1893, "in Friedrich Engels oder: Wie ein "Cotton-Lord" den Marxismus erfand, ed. Michael Krätke (Berlin: Dietz, 2020), I64.

62 Eike Kopf, "Marx ohne Engels—das wäre kaum eine halbe Sache geworden," in "Die Natur ist die Probe auf die Dialektik«: Friedrich Engels kennenlernen, eds. Elmar Altvater et al. (Hamburg: VSA Verlag, 2020), 69-89.

63 On the friendship of the two men see Jürgen Herres, Marx und Engels: Porträt einer intellektuellen Freundschaft (Stuttgart: Reclam, 2018).

64 Lafargue, "Persönliche Erinnerungen, « I87.

65 Kuczynski, „Die zweite Violine, "29; van der Linden, „Friedrich Engels's Herkunft, «I7.

66 Georg Fülberth, „Wie zwei ein Compagniegeschäft betrieben: Friedrich Engels’s Beitrag zum Werk von Karl Marx, « in "Die Natur ist die Probe auf die Dialektik«: Friedrich Engels kennenlernen, eds. Elmar Altvater et al. (Hamburg: VSA Verlag, 2020), 54-68. 
works, ${ }^{67}$ and as German political scientist Michael Krätke emphasized, "Both were arrogant, each in his own way, but together they could be obnoxious. ${ }^{68}{ }^{8}$ Regardless of Engels's intellectual capacity and expertise in many different fields ${ }^{69}$ which often even surpassed Marx, the former would never achieve similar authority. ${ }^{70}$ In the early I850s, Engels wrote all of their works on military issues and foreign affairs, including the English articles Marx would publish under his own name in the New York Daily Tribune. ${ }^{71}$

It is safe to say, to quote Michael Krätke once more, "that there would not have been Marxism without Engels, $«{ }^{72}$ as the latter was the first who sought, especially after his friend's death, to make Marx's writings known to a wider public. It was probably the humbleness of Engels - who always would refer to himself as the second fiddle, a talent, and to Marx as a genius - that made the rise of Marx and his legacy possible. The two men might have appeared like an »inseparable duo, ${ }^{73}$ yet Engels, often intentionally, tended to stand in the shadow of his friend. ${ }^{74}$ Regardless of his humbleness, Engels was important for Marx in many ways. He, according to Krätke, was a "guide, stimulator, a source of ideas, a thought leader and a critic «7 ${ }^{75}$ alike and pretty heavily influenced the latter's economic works. ${ }^{76}$ It was also Engels who actually repeatedly insisted that Marx publish his works while providing his friend with the necessary time and financial security to do so. ${ }^{77}$ Engels would help Marx, according to the latter's own statement, at any time

67 Lafargue, "Persönliche Erinnerungen, « I89.

68 Krätke, »Friedrich Engels, « I3.

69 Lafargue, "Persönliche Erinnerungen, « I9I.

70 Ibid., I87-188.

7I Krätke, »Friedrich Engels, « 9 .

72 Ibid., Io.

73 Ibid., II.

74 Ibid., I2.

75 Ibid., 25 .

76 Conrady, "Friedrich Engels, " I0027; Herres, Marx und Engels, 46; Krätke, »Friedrich Engels, « 29.

77 Conrady, »Friedrich Engels, « I0027; Fülberth, Friedrich Engels, 69. 
and in any condition..$^{78}$ This support was essential for Marx's works and, therefore, one cannot omit the Engelsian influence when talking about these important writings of the igth century. In addition, in the years after Marx's death, Engels worked relentlessly for the Marxian legacy and, after I883, he became the spiritual head of international socialism. ${ }^{79}$ He edited volumes 2 and 3 of Capital, an undertaking for which he was criticized because some people argued that he had not only changed but falsified parts of the work. ${ }^{80}$ Engels had attempted to make the work more appealing to the masses, although he could not complete it either, and Capital remained "an incomplete masterpiece. ${ }^{\text {8I }}$ He might have therefore been the "first Marxist, " although he did not consider it to be an orthodoxy but rather a work in progress that needed to be reframed according to the historical and existent circumstances. ${ }^{82}$

Marxism was not a doctrine for Marx and Engels, but rather

I. a historical-materialist analysis of economy and class relations,

2. a political theory based on this analysis, and

3. a political practice that demands the end of a capitalist society. ${ }^{83}$

It is hard to understand this by a divided analysis of the works of Marx and Engels, which must rather be seen as a compendium in which the single works relate to each other. This, however, should also not deny some kind of intellectual individualism, especially since too often the two men were pressed into an almost religious duality. ${ }^{84}$ There were also attempts to divide them, even to antagonize them. Marx was considered the universal thinker, and Engels the one responsible for

$78 \quad M E W 28: 596$.

79 Labica, »Friedrich Engels, « I7-I9.

80 Krätke, "Friedrich Engels, " 39-4I; van der Linden, „Friedrich Engels’s Herkunft, «23-24.

8I Krätke, "Friedrich Engels, « 43.

82 Bergmann, et al. „Einleitung, « I2; Fülberth, Friedrich Engels, 8; Krätke, »Friedrich Engels, « 54-56.

83 Fülberth, Friedrich Engels, 9.

84 Bergmann, et al. »Einleitung, « 9; Krätke, »Friedrich Engels, « I3. 
the flattening of his friend's ideas that could then be corrupted by totalitarian systems, e. g. Stalinism. ${ }^{85}$

In contrast to such arguments, it is important to understand Engels as an intellectual who tried to practically apply his thoughts to change society ${ }^{86} \mathrm{His}$ experiences in English factories, his participation in the Revolution of 1848 , and his almost endless hunger for knowledge helped to forge his and Marx's intellectual work. He must therefore be considered an equal to Marx, and nothing less. The negative or anti-Engelsian attitude does not take into account that Engels, despite being in steady contact with the SPD leadership since the r88os, i. e. August Bebel (1840-1913) or Eduard Bernstein (1850-1932), never gave up his belief in a better future, which could only be achieved by a revolution of the masses ${ }^{87}$ It is this belief, next to his many works that seem to have never lost their actuality, that makes Engels important for the 2ist century as well.

While Marx is-also academically-en vogue again since criticisms of global hyper-capitalism have gained ground, ${ }^{88}$ especially during the COVID-19 crisis, which due to its impact threatens the further existence of capitalism as such, Engels has still not received the necessary attention. Those in circles on the left, especially those who call themselves Marxists today, still tend to make him responsible for the failures of regimes that used supposedly Marxist doctrines to legitimize their rule ${ }^{89}$ and use Engelsism as a derogative term..$^{\circ \circ}$ Nevertheless, the 20oth birthday of Engels stimulated some interest,

85 Bergmann, et al. "Einleitung, « Io.

86 Hunt, Friedrich Engels, I6.

87 Fülberth, Friedrich Engels, 72. For Engels's relation with and impact on German Social Democracy also see Detlef Lehnert and Christina Morina, eds. Friedrich Engels und die Sozialdemokratie: Werke und Wirkungen eines Europäers (Berlin: Metropol, 2020).

88 Especially the 20oth birthday of Marx in 2018 stimulated some public and academic interest again. For one of the recent surveys on problems and thoughts related to his legacy see Martin Endreß and Christian Jansen, eds. Karl Marx im 2I. Jahrhundert: Bilanz und Perspektiven (Frakfurt am Main: Campus, 2020).

89 Hunt, Friedrich Engels, 8; Labica, "Friedrich Engels, « 20.

90 Krätke, »Friedrich Engels, « 58. 
especially in Wuppertal, where many events commemorated his legacy. ${ }^{\text {II }}$ Regardless of such events, it is more than timely to bring Engels back into the spotlight and to re-read his writings, especially since they offer so many insights into a variety of problems our society still struggles with and will have to deal with in the 2Ist century. It is time to draw him out of Marx's shadow ${ }^{92}$ and to emphasize his actuality, e.g. with regard to questions of housing, ${ }^{93}$ family theory, ${ }^{94}$ or gender-related discussions..$^{95}$ As was already argued 25 years after his death, Engels "must not be a simple name for the current generation, « but must become a »role model and teacher ${ }^{96}$ instead. Engels never feared to learn something new or to be critical with regard to his own views either. ${ }^{97}$ We should be as critical and try to learn from Engels's experiences in the 19th century for our own benefit in the 2Ist century. There is much to learn, and, if applied, the knowledge Engels provides us with might be decisive for formulating our own revolutionary dream that can become a reality if the global masses share it.

9I Rainer Lucas, Reinhard Pfriem and Hans-Dieter Westhoff, „Einleitung der Herausgeber, "in Arbeiten am Widerspruch: Friedrich Engels zum 200. Geburtstag, eds. Rainer Lucas, Reinhard Pfriem and Hans-Dieter Westhoff (Marburg: Metropolis-Verlag, 2020), I3.

92 Ibid., I4.

93 Burghard Flieger, "Engels’s Stellungnahme zur Wohnungsfrage: Anstöße für zukunftsfähige wohnungsbaugenossenschaftliche Konzepte?" in Arbeiten am Widerspruch: Friedrich Engels zum 200. Geburtstag, eds. Rainer Lucas, Reinhard Pfriem and Hans-Dieter Westhoff (Marburg: Metropolis-Verlag, 2020), 335. An essential text by Engels related to this question is Friedrich Engels, "Zur Wohnungsfrage, « in $M E W_{\text {I }}$, 5: 209-287.

94 Gisela Notz, »Auseinandersetzung mit Friedrich Engels's ,Ursprung der Familie ....: ... und was er uns heute noch zu sagen hat, "in Arbeiten am Widerspruch: Friedrich Engels zum 200. Geburtstag, eds. Rainer Lucas, Reinhard Pfriem and Hans-Dieter Westhoff (Marburg: Metropolis-Verlag, 2020), 398-404.

95 Adelheid Biesecker, Frigga Haug und Uta von Winterfeld, "Nachdenken mit Friedrich Engels: Über Geschlechterverhältnisse und gesellschaftliche Naturverhältnisse, " in Arbeiten am Widerspruch: Friedrich Engels zum 200. Geburtstag, eds. Rainer Lucas, Reinhard Pfriem and Hans-Dieter Westhoff (Marburg: Metropolis-Verlag, 2020), 4I7-438.

96 Conrady, »Friedrich Engels, « IOO27.

97 Labica, "Friedrich Engels, «2I. 
The present volume must consequently be understood as an attempt to give a survey of questions and topics to which Engels's thoughts and writings can be applied, or at least taken into consideration. It offers an insight into Engels's broad variety of ideas and experiences, and it hopes to stimulate further research on the man who was so important for the intellectual lives of so many who tried to follow in his footsteps. The first three chapters-by Vitor Bartoletti Sartori, Frank Jacob and Jia Feng — will describe Engels's view of dialectics and history. They will not only analyze the role of dialectics in his historical worldview, but will also show how Engels understood revolutions as historical processes that are linked to a specific space-time continuum and what we can make of Engels's theoretical concepts when they are applied to a concrete analysis of a historical case study. In the following contributions, Renildo Souza, David Pavón-Cuéllar, Maria Rosario and Gottfried Schweiger will shed light on some fields Engels was also interested in when they discuss his works in the field of political economy, his psychology and his reflections on empirism and ideology, and his thoughts about both evolutionist ethnology as well as the philosophy of nature.

That Engels intellectually offers much more than reflections about historical materialism is also shown by Henrique Wellen's analysis of Engels's understanding of the relationship between art and politics and Vincent Streichhahn's chapter on the 'woman question ‘ and social reproduction theory from an Engelsian perspective. The existence of Engels's minor role, at least with regard to his perception in the digital age, is analyzed by Riccardo Altieri, before Nuruddin Al Akbar discusses a critical reading of Engels's perspective in a time that is currently so heavily determined by the COVID-I9 pandemic. Last but not least, Alexander Maxwell provides a practical insight and shows why Engels provides a course reading for history classes in the 2Ist century that will not only engage students much better than Marx's Capital but also open the eyes of those who might be in steady contact with global capitalism yet do not understand its functionality.

All in all, the editor and the authors hope that Engels will receive more attention from activists and scholars alike because his works 
and legacy remain timely and relevant in a century that faces many crises. If a revolution of the masses can eventually change the world and, through the abolishment of capitalism, turn it into a better place, this might rely on a revival of Friedrich Engels, whose works provide at least a theoretical map to solve the problems of humanity during our century.

\section{Works Cited}

Altieri, Riccardo and Bernd Hüttner, eds. Klassismus und Wissenschaft. Erfahrungsberichte und Bewältigungsstrategien. Marburg: BdWi-Verlag, 2020.

- " "Paul Frölich, American Exile, and Communist Discourse about the Russian Revolution." American Communist History 17, no. 2 (2018): S. 220-23I.

Bergmann, Theodor, Mario Keßler, Joost Kircz and Gert Schäfer. "Einleitung." In Zwischen Utopie und Kritik: Friedrich Engels—ein "Klassiker" nach Ioo Jahren, eds. Theodor Bergmann, Mario Keßler, Joost Kircz and Gert Schäfer, 9-13. Hamburg: VSA, 1996.

Biesecker, Adelheid, Frigga Haug und Uta von Winterfeld. „Nachdenken mit Friedrich Engels: Über Geschlechterverhältnisse und gesellschaftliche Naturverhältnisse. «In Arbeiten am Widerspruch: Friedrich Engels zum 200. Geburtstag, eds. Rainer Lucas, Reinhard Pfriem and Hans-Dieter Westhoff, 4I7-438. Marburg: Metropolis-Verlag, 2020.

Bleuel, Hans Peter. Friedrich Engels: Bürger und Revolutionär. Bern/Munich: Scherz, 198I.

Britovšek, Marjan. "Die slawischen Nationalbewegungen und die Perspektiven der Revolution." In Zwischen Utopie und Kritik: Friedrich Engels—ein "Klassiker" nach too Jahren, eds. Theodor Bergmann, Mario Keßler, Joost Kircz and Gert Schäfer, I40-156. Hamburg: VSA, 1996.

Conrady, A. "Friedrich Engels. Beilage zum Wahren Jacob, No. 887, July 30, 1920: 10027-10028.

Endreß, Martin and Christian Jansen, eds. Karl Marx im 2I. Jahrhundert: Bilanz und Perspektiven. Frakfurt am Main: Campus, 2020.

Engels, Friedrich. "Das Jahr I848 war das Jahr der Enttäuschung," I7.III. [1849] IISH, Karl Marx/Friedrich Engels Papers, ARCHoo86o, H_8. 
—. "Interview mit dem Korrespondenten der Zeitung L'Éclair am I. April I892." In Friedrich Engels oder: Wie ein "Cotton-Lord" den Marxismus erfand, ed. Michael Krätke, 153-158. Berlin: Dietz, 2020.

—. "Interview mit dem Korrespondenten der Zeitung Le Figaro am 8. Mai I893."In Friedrich Engels oder: Wie ein "Cotton-Lord" den Marxismus erfand, ed. Michael Krätke, I59-165. Berlin: Dietz, 2020.

—. »The Peasant War in Germany« (I850). Accessed August 20, 2020. https:// www.marxists.org/archive/marx/works/1850/peasant-war-germany/ index.htm.

Flieger, Burghard. „Engels’s Stellungnahme zur Wohnungsfrage: Anstöße für zukunftsfähige wohnungsbaugenossenschaftliche Konzepte? «In Arbeiten am Widerspruch: Friedrich Engels zum 200. Geburtstag, eds. Rainer Lucas, Reinhard Pfriem and Hans-Dieter Westhoff, 335-363. Marburg: Metropolis-Verlag, 2020.

Fülberth, Georg. „Endlich angekommen: Friedrich Engels's Londoner Jahre 1870-1895." In Friedrich Engels: Ein Gespenst geht um in Europa-Begleitband zur Engelsausstellung 2020, ed. Lars Bluma, I82-195. Wuppertal: Historisches Zentrum Wuppertal, 2020.

-. Friedrich Engels. Cologne: PapyRossa, 2018.

—. "Wie zwei ein Compagniegeschäft betrieben: Friedrich Engels's Beitrag zum Werk von Karl Marx." In "Die Natur ist die Probe auf die Dialektik»: Friedrich Engels kennenlernen, eds. Elmar Altvater et al., 54-68. Hamburg: VSA Verlag, 2020.

Herres, Jürgen. "Friedrich Engels: Republikanischer Kommunist und europäischer Gesellschaftskritiker." In Friedrich Engels: Ein Gespenst geht um in Europa-Begleitband zur Engelsausstellung 2020, ed. Lars Bluma, I6-29. Wuppertal: Historisches Zentrum Wuppertal, 2020.

-. Marx und Engels: Porträt einer intellektuellen Freundschaft. Stuttgart: Reclam, 2018.

Hunt, Tristram. Friedrich Engels: Der Mann, der den Marxismus erfand, transl. by Klaus-Dieter Schmidt, third edition. Berlin: List, 2020.

Ito, Narihiko. "Realismus und Utopismus." In Zwischen Utopie und Kritik: Friedrich Engels—ein "Klassiker" nach Ioo Jahren, eds. Theodor Bergmann, Mario Keßler, Joost Kircz and Gert Schäfer, 23-33. Hamburg: VSA, 1996.

Kopf, Eike. "Marx ohne Engels—das wäre kaum eine halbe Sache geworden." In "Die Natur ist die Probe auf die Dialektik": Friedrich Engels kennenlernen, eds. Elmar Altvater et al., 69-89. Hamburg: VSA Verlag, 2020. 
Krätke, Michael. "Friedrich Engels, der erste Marxist." In Friedrich Engels oder: Wie ein "Cotton-Lord" den Marxismus erfand, ed. Michael Krätke, 9-68. Berlin: Dietz, 2020.

Kuczynski, Thomas. "Die zweite Violine." In "Die Natur ist die Probe auf die Dialektik«: Friedrich Engels kennenlernen, eds. Elmar Altvater et al.. 27-34. Hamburg: VSA Verlag, 2020.

Labica, Georges. „Friedrich Engels_-Wissenschaftler und Revolutionär.» in Zwischen Utopie und Kritik: Friedrich Engels-ein "Klassiker" nach Ioo Jahren, eds. Theodor Bergmann, Mario Keßler, Joost Kircz and Gert Schäfer, 17-22. Hamburg: VSA, 1996.

Lafargue, Paul. »Persönliche Erinnerungen. "In Friedrich Engels oder: Wie ein "Cotton-Lord" den Marxismus erfand, ed. Michael Krätke, I85-I94. Berlin: Dietz, 2020.

Lehnert, Detlef and Christina Morina, eds. Friedrich Engels und die Sozialdemokratie: Werke und Wirkungen eines Europäers. Berlin: Metropol, 2020.

Lucas, Rainer, Reinhard Pfriem and Hans-Dieter Westhoff. „Einleitung der Herausgeber."In Arbeiten am Widerspruch: Friedrich Engels zum 200. Geburtstag, eds. Rainer Lucas, Reinhard Pfriem and Hans-Dieter Westhoff, I3-23. Marburg: Metropolis-Verlag, 2020.

Mayer, Gustav. Friedrich Engels: Eine Biographie, Bd. I: Friedrich Engels in seiner Frühzeit, I820 bis I85I. Berlin: Julius Springer, I920.

Notz, Gisela. "Auseinandersetzung mit Friedrich Engels's `Ursprung der Familie ....: ... und was er uns heute noch zu sagen hat."In Arbeiten am Widerspruch: Friedrich Engels zum 200. Geburtstag, eds. Rainer Lucas, Reinhard Pfriem and Hans-Dieter Westhoff, 397-4I6. Marburg: Metropolis-Verlag, 2020.

Radziejowski, Janusz. »Roman Rosdolsky: Man, Activist and Scholar.» Science \&r Society 42, no. 2 (1978): 198-210.

Reuter, Julia, Markus Gamper, Christina Möller and Frerk Blome, eds. Vom Arbeiterkind zur Professur: Sozialer Aufstieg in der Wissenschaft. Autobiographische Notizen und soziobiographische Analysen. Bielefeld: Transcript Verlag, 2020.

Rhefus, Reiner. Friedrich Engels im Wuppertal: Auf den Spuren des Denkers, Machers und Revolutionärs im "deutschen Manchester". Hamburg: VSA, 2020.

Rosdolsky, Roman. Zur Entstehungsgeschichte des Marxschen Kapital. Frankfurt am Main/Vienna, I968. 
Roth, Regina. "»Die Lage der arbeitenden Klasse in England von Engels im Spiegel ihrer Zeit (1845-I892)." In Friedrich Engels: Ein Gespenst geht um in Europa-Begleitband zur Engelsausstellung 2020, ed. Lars Bluma, 84-99. Wuppertal: Historisches Zentrum Wuppertal, 2020.

San Juan, Jr., Epifanio. „Was wir aus Engels’s revolutionärer Ästhetik lernen können." In Zwischen Utopie und Kritik: Friedrich Engels—ein "Klassiker" nach Ioo Jahren, eds. Theodor Bergmann, Mario Keßler, Joost Kircz and Gert Schäfer, 68-91. Hamburg: VSA, 1996.

van der Linden, Marcel. "Friedrich Engels's Herkunft und Lebensleistung: Eine biografische Skizze.«In "Die Natur ist die Probe auf die Dialektik«: Friedrich Engels kennenlernen, eds. Elmar Altvater et al., 7-26. Hamburg: VSA Verlag, 2020.

Vonde, Detlef. Auf den Barrikaden: Friedrich Engels und die "gescheiterte Revolution« von I848/49. Wuppertal: Köndgen, 2019. 


\title{
Notes on Dialectics and History in Friedrich Engels ${ }^{1}$
}

\author{
Vitor Bartoletti Sartori
}

Engels was certainly the closest collaborator of Marx. And that-for those who, with the help of Marxist thought, aim to understand and effectively criticize bourgeois society-is not a minor thing. It is worth stressing the issue in a double sense in relation to the two authors in order to formulate an effective critique of capital: first, Engels was the author of The Condition of the Working Class in England, and was the person who brought many of the works of Marx (books II and III of Das Kapital were organized by Engels!) to the wider public; secondly, it is important to state that special attention must be given to the "second fiddle insofar as Engels contributed significantly in his dialogues with Marx, which is evident in their letters, in the books they wrote together, and in the close friendship that the two socialists developed. It is important to note then that when we read Marx, to a certain extent, we also read Engels. Conversely, when we read Engels, we also read his friend Marx. For Marxists, there is no possibility of treating Engels as a secondary figure. At the same time, it is important to point out that in spite of the similitude between both authors ideas and positions (Standpunkt), there are significant differences that in some crucial topics (such as the question of the organization of the State and the right to suppress (Aushebung) bourgeois society) can be decisive for those who embrace Marxism as their frame of reference.

Here we try to delineate an Engelsian treatment of dialectics and history, mainly taking into consideration his work after The Paris

I This chapter is a translation of "Apontamentos sobre dialética e história em Friedrich Engels, "Verinotio revista online 20 (20I4) ISSN 198I-06IX. We thank the author and the journal for the permission to publish this translation. 
Commune, an event impeccably treated by Marx in his The Civil War in France. This approach is justified in that it is a collaboration between the author of Anti-Dühring and those who later became prominent leaders of the commune and gained prominence in the socialist camp in Germany, Kautsky and Bernstein. We cannot deal in detail here with how Engels was appropriated (many times erroneously) by these authors, who became responsible for the vulgarization of Marxism. Nor can we deal with all the differences between Marx and Engels. We will only approach the topic to the extent that it deals with the methodological foundation of a critique of capitalist society. We will demonstrate the way in which Engels's position fits in this field without neglecting Marx. In this way, we will show the existence of certain points of tension in Engels's work.

The author of Anti-Dühring was explicit in what he wrote about the necessary critique of common sense: "common sense, a very respectable character, behind closed doors, between the four walls of a house, lives truly marvelous adventures, when it dares to enter the wide field of research. ${ }^{2}$ This means that it is necessary to apply special care when dealing with complex issues such as the State or history. Without this care, our reasoning could be tainted with a metaphysical appeal rather than a dialectic one. There would be a tendency to hypothesize social relations on a daily basis, giving them a ghostly appearance and reifying them in such a way that it would be "a unilateral method, limited, abstract " that "gets lost in unresolvable contradictions since, absorbed by concrete objects, it cannot see its relationships. $\|^{3}$ The $"$ reflexive determinations" $(R e-$ flexionsgestimmungen) of the effective reality (Wirklichkeit) will be eclipsed by common sense, which makes it necessary to break away from a linear thought that is too attached to a shallow conception of the causality of social reality, a conception in which "cause and effect take the shape of a rigid anti-thesis. $\aleph^{4}$ In this way, Engels attacked

$\begin{array}{ll}2 & \text { Friedrich Engels, Anti-Dühring (Rio de Janeiro: Paz e Terra, I990), } 20 . \\ 3 & \text { Ibid. } \\ 4 & \text { Ibid. }\end{array}$ 
two twin aspects of a »metaphysical« vision. On the one hand, he criticized the reification of social relationships marked, among other things, by the loss of a rational and effectively concrete dimension of the effective reality. On the other hand, he points out that the highlighted relationship is not simply antithetical or marked by unsolvable antinomies. It is necessary to overcome these antinomies with a type of thought that "reflects its genesis and its lapse «s in such a manner that it is understood as something inseparable from forms of being (Daseinformen), determinations of existence (Existenzbestimmungen) that are constituted by effectiveness itself. Contrary to this position, there is "the metaphysical individual " who "thinks in a whole series of disconnected anti-theses: for him there is only a simple yes or no, and when he gets out of these molds, he finds only disorder and confusion. $«^{6}$

Therefore, we must recognize that there is a critique of the way in which the quotidian takes form. To the extent that the "speculative method seems to us extremely plausible, because of the so-called common sense, ${ }^{7}$ it is clear that what is opposed to common sense is not "speculation, " which is nothing more than the other face of knowledge tied to immediacy. Thus, it would be necessary to question common sense as well as the "speculative method" in a decisive manner. And this, Engels intended, would be accomplished with the dialectical method, which had been inherited from Hegel but had been superseded (aufgehoben) by Marx when he took into account the contradictions present in the Hegelian system.

This occurred in the exact measure in which the "method" was centralized, opposing, in Hegel, the "system. " $^{8}$ The author of Phenomenology of Spirit, then, at the same time that he brought up something already different from "metaphysics, « did not stop pay-

$\begin{array}{ll}5 & \text { Ibid. } \\ 6 & \text { Ibid. } \\ 7 & \text { Ibid. } \\ 8 & \text { See Engels, Anti-Dühring. }\end{array}$


ing homage to it, even when he tried to supersede it. ${ }^{9}$ In the words of Marx, there was a situation in which, "in its mystified form, the dialectic was a German fashion because it seemed to turn the existent into the sublime, ${ }^{\mathrm{IO}}$ which is linked to the way in which Hegel equated reconciliation (Vörsonung) and the rationality of the real. ${ }^{\text {II }}$ If we follow Engels's reasoning, then in Hegel there was the inability to follow the very "method " in which, according to the author of AntiDühring, just as would happen with Marx, "movement is a mode of material existence. ${ }^{12}$ That is to say, dialectics would oppose a view in which concepts "are isolated objects of research, fixed objects, immutable, one observed after the other, each one per se, like something determined and perennial. « ${ }^{13}$ Indeed, Hegel himself, according to Engels, would not have been consistent with this:

Indeed, his philosophy still suffered from a great incurable contradiction since, on the one hand, he considered it essential to the historical conception, according to which human history is a process of development that cannot, by its very nature, find an intellectual solution to the discovery of what are called absolute truths. On the other hand, it presents itself as a summary or compendium of those

9 According to Salgado, a Hegelian, there is a new form of metaphysics in Hegel: "There remains the possibility of a metaphysics of reason to replace the metaphysics of understanding " (Joaquim Carlos Salgado, A ideia de justiça em Hegel (Petrópolis: Loyola, 1996), 56).

Io Karl Marx, O capital bk. I, vol. I, transl. by Régis Barbosa and Flávio R. Kothe (São Paulo: Nova Cultural, 1988), 27.

II To a certain extent, according to Engels's comments, Lukács states: "This reconciliation is, on the one hand, an idealist mystification of unresolvable contradictions, but on the other hand, it expresses at the same time the realist sense of Hegel, its proximity to the concrete social reality of his time, his profound knowledge of the real life of human society, his efforts to discover the contradictions of progress in its true battlefield, which is in the economic life of man." György Lukács, El joven Hegel y los problemas de la sociedad capitalista, transl. by Manuel Sacristán (México: Grijalbo, 1963), 413.

I2 Engels, Anti-Dühring, $5 \mathrm{I}$.

I3 Ibid., 20. 
absolute truths. A universal and compact system, definitively shaped, which is intended to frame both natural science and history, is incompatible with the laws of dialectics. ${ }^{\mathrm{I}}$

The "laws of dialectics « would be incompatible with the Hegelian process, marked, at the same time, by an emphasis on becoming - which comes from the dialectic between being (Sein) and nothing (Nichts), according to the author of The Science of Logic - , on movement, and on a systematic philosophy ("a universal and compact system «) that conforms to a "summary and compendium « of "absolute truths."

In other words, the problem of Hegelian dialectics is twofold: while it would have been a "lesser" dialectic in seeking a systematic philosophy in which effective reality would be viewed as a certain closure, it would at the same time have been-in the wake of Shelling - a "greater" dialectic in seeking to frame "natural science and history « in a universal system with the necessary mediations. On the one hand, then, the author of Phenomenology of Spirit would have been inconsistent with his own assumptions; on the other hand, however, with these very assumptions, he would have been taken to a systematic and universal "application « of the dialectic, which would require greater care-if we were to follow Engels's observations. ${ }^{15}$ And with that, Hegel was criticized while his merits were recognized, including, by the way, by Marx.

Nevertheless, at this point, some caution is necessary. It must be noted how the author of Anti-Dühring put himself above the dialectic. There were "fundamental laws of dialectical thought, " which »do not exclude but rather imply that the systematic knowledge of the external world in its totality could progress with giant steps generation after generation. ${ }^{16}$ At this point, Engels seems to oppose the system-

\footnotetext{
I4 Ibid., 22-23.

I5 See Friedrich Engels, Dialética da natureza (Rio de Janeiro: Paz e Terra, 1979).

I6 Friedrich Engels, Do socialismo utópico ao socialismo cientifico \& Ludwig Feuerbach e o fim da filosofia clássica alemã, transl. by José Severo de C. Pereira (São Paulo: Fulgor, 1962), 60.
} 
atic character of Hegelian thought with another form of "systematic knowledge, « a form that would be more open. It is clear that with this the author wanted to say that we are talking about knowledge of "the exterior world in its totality" and, in this sense (the separation between subject and object is already being assumed in the notion of the "outside world, « essential for any materialist position), he demonstrates a decisive distancing from Hegel, who considers the identical subject-object of speculative idealism as something essential. ${ }^{17}$ However, we must recognize that it is still uncomfortable for those who know the work of Marx, which is marked by the immanence of the objectivity and historicity of being ${ }^{18}$ — a diction that intimately links a "system " (evidently distinct from that of Hegel) to the "fundamental laws of dialectical thought."

With this intonation, one could, at times, fall into the temptation of believing that it would be a matter of "correctly applying " a "method « in order to reach a way of apprehending effectiveness that would be real and effectively dialectical. ${ }^{19}$ In this sense, contrary to what we see in Marx ${ }^{20}$, the "method, " in Engels, could provide an opportunity (if one were not to deal carefully with effectiveness [Wirklichtkeit]) with an epistemological apparatus and not with the real fabric of reality. Thus, we cannot dismiss a reading according to which there would be a certain impetus that is simultaneously gnoseological and logical in its way of apprehending Engels; this is precisely the thesis of

I7 It is important to note that certain Marxists tend to disagree with Engels with regard to the closed character of the Hegelian system. See Paulo Arantes, Hegel e a ordem do tempo (São Paulo: Hucitec, 1982).

I8 See Vitor Bartoletti Sartori, "De Hegel a Marx: da inflexão ontológica à antítese direta, "Kriterion 55, no. 130 (2014): 69I-713.

I9 Marx was clear when he said "the materialist method becomes its own anti-thesis when it is utilized not as a thread conducting historical research but rather as a finished model to which one must adapt historical facts" (Karl Marx and Friedrich Engels, Cultura, arte e literatura: textos escolhidos, transl. by José Paulo Netto (São Paulo: Expressão Popular, 20Io), II9.

20 See José Chasin, Marx: estatuto ontológico e resolução metodológica (São Paulo: Boitempo, 2009). 
an important theoretician like György Lukàcs, ${ }^{21}$ reinforced by the fact that Marx's main collaborator, at the end of his life, tried to develop a "dialectic of nature, « a theme that, unfortunately, we cannot deal with in this article but is highly polemical in the Marxist literature.

We should note that it is not that nature ought to be considered in a static way, or that there is a tight opposition between the spirit sciences and the natural sciences, as Löwy ${ }^{22}$ seems to point out in the footsteps of Dilthey. It happens, however, that its movement could not, as Engels sometimes implied, ${ }^{23}$ be quasi-deduced from the "laws of dialectics. " Engels had a very peculiar way of dealing with dialectics, searching for the »laws of dialectics" (»interdependency of opposites, " "quantitative leap, " and "negation of negation") at the same time as he criticized a way of thinking marked by "the intellectual solution in the discovery" of "what are called absolute truths, " which shelter a "compact universal system. "In other words, as much as the "spirit" of the author's text could diametrically oppose a Hegelian »intellectual solution, « it merges with a certain way of thinking in which the "method, " at times, seems to be taken as dissociated and dissociable from the object (Gegenstand) and from objectivity itself. In Marx, there is no being (Wessen) lacking determinations and marked, logically, by the becoming of movement, but there is an understanding of categories as ways of being driven by historicity that break with a state of being "concentrated in its static condition ${ }^{24}$ only insofar as it deals with the complex mediations between man and nature, and among humans themselves (to the extent that human praxis, realized under conditions linked by the past, ${ }^{25}$ is focused more on its own immanence of »sensitive human activity« [sinnlich menchliche Tätigkeit $]$ ).

2I See György Lukács, Prolegômenos para uma ontologia do ser social, transl. by Lya Luft and Rodnei Nascimento (São Paulo: Boitempo, 2010).

22 See Michel Löwy, As aventuras de Karl Marx contra o Barão de Münchhausen (São Paulo: Cortez, 1994).

23 Engels, Dialética.

24 Engels, Anti-Dühring, 20.

25 As Marx says, "men make their own history, but they do not make it according to their free will; they do not make it under circumstances that they choose 
In this specific sense, as Lukács has already suggested in The History of Class Consciousness ${ }^{26}$ — although with a different prism in his critique of Engels - , it may be possible to say that the author of Anti-Dühring stopped focusing on decisive aspects of the praxis inasmuch as he brought to light the "laws of dialectics."In a way, the position according to which it would not be a question of opposing the preceding idealism would be eclipsed by a contemplative materialistic position in which "the object [objekts], reality [Wirklichtkeit], the sensitive [Sinnlichtkeit] is apprehended in the form of the object or contemplation [Anschauung] but not as sensitive human activity, as a practice [praxis], not subjectively. $\ll^{27}$ Engels, in this sense, would bring with him a limited conception of dialectics.

At the same time that he approached Hegel, Engels criticized him based on the opposition of "system « and "method «; he came to stress the autarchy of effective reality, breaking with the conception of Hegelian science (related to the systematic treatment of all knowledge and reality). We also should take into consideration this aspect of the tensions within the thought of the author of Anti-Dühring:

From the moment that each science has to account for its position in the Universal framework of things and the knowledge of those things, there is no longer room for a science especially dedicated to the study of universal concatenations. From the previous philosophy, with its own existence, there only remains afoot the theory of thinking and its laws: formal logic and dialectics. The rest is dissolved in the positive science of nature and history. ${ }^{28}$

but under those that they face directly, linked and transmitted by the past. The tradition of all dead generations oppresses, like a nightmare, the brains of those who are alive. "Karl Marx, O I8 Brumário de Luis Bonaparte, transl. by Leandro Konder and Renato Guimarães (Rio de Janeiro: Paz e Terra, I997), 2I.

26 György Lukács, História e consciência de classe, transl. by Rodnei Nascimento (São Paulo: Martins Fontes, 2003).

27 Karl Marx and Friedrich Engels, $A$ ideologia alemãa, transl. by Rubens Enderle (São Paulo: Boitempo, 2007), 533.

28 Engels, Socialismo utópico, 60-6I. 
Engels was clear about what came to be known as "the end of classical German philosophy, «" ${ }^{29}$ concatenated to the extent that the task of philosophy would no longer refer to a posture that would not be, in itself, a taken position and would refer to praxis, "sensitive human activity« being something that would not accept the rigid dichotomy between reason and sensitivity, nor the dissolution of the sensitive into a form of Aufhebung in reason. Thus, according to the appreciation of the immanence of effective reality, Engels was consistent in valuing science. He also emphasized the impossibility of any form of hypostasis of universality ${ }^{30}$ (which, at times, seemed to happen in Hegel's own Science and Logic, and in Plato before him), with reason. However, maybe Engels was in a rush to deal with philosophy as something that remains only a "theory of thinking and its law," something that refers to a conception as a bias that can, in some circumstances, acquire a memorable gnoseological tonality in which it is a matter of "applying " a "method " marked by the valorization of the »dialectical laws" - which did not arrive, in the author, at a "compendium" of "absolute truths, " given that there was a clear valorization of the correct apprehension of effective reality when it recognized the importance of the "positive science of history."Nevertheless, the issue can become complex if we consider that there seems to be a certain separation between "formal logic and dialectics" on the one hand and "the positive science of nature and of history» on the other. That is to say, there seems to be the possibility of thinking in terms of categories without considering "forms of being, determinations of existence«; thus, there is a certain counter-position to Marxist thought on this specific point. The "science of history" mentioned earlier brings with it the immanence of dialectics, considered the very movement

29 Ibid.

30 This a risk that could not be taken: as Marx had already stated in I842, the best hypothesis runs the risk of falling into the trap of Hegelian dialectic, which, "as a universal in itself, I turned into something independent; it is immediately mistaken with empirical existence and then the finite is tuned in an uncritical manner into the expression of an idea." Marx and Engels, A ideologia alemā, 77. 
of the real, and now the question emerges in a somewhat different way, breaking apart — at least when it comes to exposition (Darstellung) — the unity between "method" and effective reality.

It is clear that Engels did not create a simple apology for the partial sciences, being consistent with a position that he, along with Marx, defended in German Ideology. ${ }^{3 \mathrm{I}}$ He placed them in a position to be criticized in that he highlighted only the "positive science of nature and history." However, it is impossible not to notice a certain opposition between "the laws of dialectics, " present in what was left of the philosophy of yore, and the apprehension of historical objectivity itself, since Marx explicitly said that the "materialist method" presents itself "as a conducting thread of historical investigation" and is inseparable from it, from the apprehension of its own effective reality.

Marx emphasized in Capital that »it is, without doubt, necessary to distinguish the method of presentation [Darstellungsweise], formal-

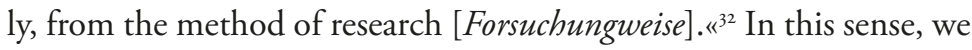
can understand Engels's note as him being careful not to juxtapose both moments of the apprehension of the real. However, it is important to note that Engels seems to open the door to misunderstandings, since his diction is more accessible to those who have not been initiated into the thought that Marx and the author criticized (»speculative method «) - or who are unconcerned with the themes that permeated the "previous philosophy«—and more obscure for those who seek to see the way in which the conception developed by the author of German Ideology differentiates itself from the conception of Hegel. In other words, Engels is didactic when he seeks to offer a systematic treatment of the themes of both dialectics and history (and at this point he has perhaps come too close to the language of "common sense «), and it seems confusing since he ends by leaving the possibility for the belief that it would be possible to depart from certain

3I In that work, the authors said: "There is no history of politics, of right, of science, of art, of religion, etc. "Marx and Engels, $A$ ideologia alemã, 77.

32 Marx, O capital I, 26. 
epistemic dissociations between the "laws of dialectics, " "method," and effective reality.

When we say "leaving the possibility, " an important caveat is necessary: it seems to us that the intention of Engels was not to draw a wall between the above-mentioned aspects, quite the contrary. However, maybe it is possible to find in this field of Engelsian theory the germs of the notorious distinction-divulged by the Stalinist vulgate-between "materialist dialectics" and "historical materialism, " which, verbally, sought to overcome the opposition between the present position in the partial sciences and the "speculation" marked by a certain hypostasis of the "laws of dialectics. " That is to say, the Engelsian critique of common sense and the speculative method was powerful, so powerful that it went so far as to be able to oppose even those who would follow its author.

Sometimes, therefore, the "mode of exposition" used by Engels was not the best, oscillating between the systematically exposed »laws of dialectics" and the apprehension of effective reality itself, created as a beacon of the "laws of dialectics" and carried out as a "positive science of history." It is necessary to realize, however, that in no way did the author seek, ontologically, to distinguish that which-in exposition-he separated dialectically.

Reason itself could not be considered except in connection with effectiveness in the following sense:

The French philosophers of the eighteenth century that paved the way for the Revolution appealed to reason as the only judge of everything that exists. They intended to establish a rational state, and anything that contradicted eternal reason was to be buried without pity. (...) Indeed, that eternal reason was nothing but the idealized intelligence of the middle-class men of that period, the class from which the bourgeoisie would emerge..$^{33}$

33 Engels, Anti-Dühring, 223. 
When trying to understand history, reason was seen by Engels, as by Marx, as a unitary process in which we cannot separate the "totality of relationships of production, " "the economic structure of society," the "political and judicial superstructure, « and »determined forms of consciousness, " in short, every "process of intellectual, political and social life. $\aleph^{34}$ For Engels, the notion of reason was, therefore, something inseparable from the contradictory development of the social process as a whole, being effective not to the extent that "the rational is real and the real is rational ${ }^{35}$ but rather insofar as it is a matter of seeing history as something made by man himself in the midst of objective social conflicts and with the mediation of "ideological forms, under which men acquire consciousness of those conflicts and confront them [ideologischen Formen, worin sich die Menchen dieses Konflikts bewusst werden und inh ausfechten]. " $^{36}$ The notion of reason, then, although it may contain within itself certain gnoseological detours, is essentially considered when, in the same way that it tried to mark itself as an "eternal reason, « it is defined by the finitude of the bourgeois society emerging at the time. The notion is inseparable from its ontological basis.

If Engels said that the French philosophers played an essential role in preparing the ground for the French Revolution, then it is obvious that he did not consider history as something produced by philosophers; however, at the same time, he could not fail to emphasize that the influence of "ideological forms" could be left aside when dealing with the "consciousness" of social conflicts, a consciousness that, in the midst of determined material conditions, could be decisive.

34 Karl Marx, Contribuição à crítica da economia política, transl. by Florestan Fernandes (São Paulo: Expressão Popular, 2009), 47.

35 Georg Hegel, Princípios da filosofia do direito, transl. by Orlando Vittorino (São Paulo: Martins Fontes, 2003), xxxvi.

36 Marx, Contribuição, 46. For a detailed treatment of this ideology, see Ester Vaisman, "A ideologia e sua determinação ontological, "Verinotio-Revista on-line de Filosofia e Ciências Humanas I2 (2010): 40-64. 
Consciousness or unconsciousness of the way in which effective reality is actually and effectively conformed is not a "scholastic matter «; at the same time, however, it is not the criterion for dealing with »ideological forms, " not least because, as Marx pointed out, men often operate through determinations of existence of which they are not fully aware-»they do not know it, but they do it [Sie wissen das nicht, aber sie tun es]. ${ }^{37}$ Thus, in the case brought up by Engels, even if the French philosophers had used a concept of reason that would be, in the midst of the social process of the development of capitalist society, ineluctably reconciled with the vicissitudes of the emerging bourgeois society, it would not be, on the part of these philosophers, an act of simple bad faith, of mere deception. Before, there was a prevalence of objective determinations that made "eternal reason, " in fact, operate amid the irrationality of capitalist effectiveness. Bearing this in mind, post festum, it was possible for Engels to say that »eternal reason was nothing but the idealized intelligence of middle-class man of those times, from which the bourgeoisie would emerge."

To the same extent that reason was placed as timeless and eternal, therefore, temporality and finitude left their indelible marks, and thus there did not exist a watertight separation between the immanence of objective determinations of the real and a method conceived, to a certain extent, in a gnoseological manner in the treatment of the author of Anti-Dühring. For him, the "Rational State« was not, then, simply gnoseologically mistaken (to the extent that it would not be possible for it to become effective); the effective reality that came from the process that culminated in the French Revolution carried with it the role that this ideal—-this »ideological form«—played in men's acquisition of consciousness of their own time in such a way that, even though this consciousness might have been mistaken from the gnoseological point of view, it fulfilled its function. In other words, we can see a certain tension in the Engelsian text here too.

37 Karl Marx, O capital bk. I, vol. II, transl. by Régis Barbosa and Flávio R. Kothe (São Paulo: Nova Cultural, I996), 200. 
Thus, at this moment, we can see that, at times, Engels's manner of exposition seems to go against the very thing that the author wants to say. This happens, however, to the extent that the mode of exposition and the mode of research need to gain greater relevance; we will focus on this aspect in the next part of this text, in which the question of history appears with special emphasis.

From what we have discussed, Engels's exposition was not always favorable for a better understanding of his work and the work of Marx. This happened because, in Engels, the concept of dialectics developed in a systematic manner in opposition to Marx's procedure, in which the immanent approach is more prominent. Evidently, there are statements of a general character in the Marxist work, but they were always related to a careful analysis of effective reality, with the categories always being presented as "forms of being, determinations of existence." In Engels, the issue is more nuanced.

Maybe the problem is expressed more penetratingly when we take into account the conception that that spoke of "laws of dialectics" and, at the same time, when it is pointed out categorically that, "according to the materialist conception, the decisive factor in history is, ultimately, the production and reproduction of immediate life. (18 $^{38}$ Sometimes, when dealing with history, the author of Anti-Dühring presented generalizations that were interpreted in an erroneous manner by the self-styled Marxist vulgate (i.e., by Stalinism). The reference to the "last resort «-placed alongside the "laws of dialectics «-resulted in its long and infamous career, leading to the most diverse scholarly and economic resources, even in some authors held in high regard, such as Bukharin, criticized by Lukács ${ }^{39}$ and Gramsci. ${ }^{40}$ It should be noted that it is not that the Engelsian passage is abso-

38 Friedrich Engels, Origem da família, da propriedade privada e do estado, transl. by Ruth M. Klaus (São Paulo: Centauro, 2002), Io.

39 Lukács, História e consciência.

40 Antonio Gramsci, Maquiavel: notas sobre o estado e a política. Cadernos do cárcere, vol. 3, transl. by Carlos Nelson Coutinho (Rio de Janeiro: Civilização Brasileira, 2002). 
lutely incompatible with the Marxist conception. However, there is a considerable difference between the emphasis on the $»$ real basis $\aleph^{4 r}$ and speaking of a »decisive factor in history.» The passage by Engels made it seem as if the »ideological forms under which men acquire consciousness" are, "in the last resort, " no more than epiphenomena.

From what has been stated above, even in Engels, this is not true. If "the French philosophers of the eighteenth century ... paved the way to the Revolution, " this happened to the extent that the "decisive factor « derived from human activity itself, an activity mediated by the relationships of production, by the "judicial and political superstructure, " and certainly by ideology. This activity is "sensitive human activity, " praxis, which implies the highly important role of consciousness. It is true that "it is not consciousness that determines life, but life that determines consciousness $\aleph^{42}$; however, it is equally the case that it is through ideology that, oftentimes, men acquire consciousness of social conflicts and seek to act upon them. Let us synthesize: in Engel's exposition, the way in which the different spheres of the social being take shape as reflective determinations was sometimes obscured, giving the impression of it being a social process that possesses a kind of hidden engine that exercises unilateral determination. This, in turn, occurred while the "last resort « was a much less precise image than the one used by Marx, that of the "preponderant moment" (übergreifendes Moment) placed in social production, which is »the effective starting point ... the point at which the whole process takes place again. ${ }^{43}$ Thus, once again, the exposition hinders the understanding of the Engelsian text.

It happens, however, that the objective concatenations of history are effectively seen in a somewhat automatic manner in Engels: when dealing with the first Bonaparte and the historical situation of France, for example, Engels_-faced with historical necessity and the »laws of dialectics«-tended to eclipse the role of consciousness, and even

4I Marx and Engels, $A$ ideologia alemã; Marx, Contribuição.

42 Marx and Engels, $A$ ideologia alemã, 94.

43 Karl Marx, Grundrisse, transl. by Mário Duayer (São Paulo: Boitempo, 20II), 49. 
that of individual differences, stating that if it had not been Napoleon, another individual would have taken his place. In a century like the nineteenth century, strongly influenced by the specter of the Little Corporal, the position of the author of Anti-Dühring undoubtedly deserves criticism. First, Engels dealt with Napoleon's shadow, a phenomenon that certainly had deep social roots (from which he could not be dissociated), but he also depended on the personality of the Emperor. Amidst the "laws of dialectics, « we can see the failure of the republican model of the French Revolution ${ }^{44}$ as well as the contradictory way in which this failure took place in 18 Brumaire as something necessary and in such a way that there seems to be a certain logical necessity directing history in the way conceived by Engels. ${ }^{45}$

That is to say that even though Hegel is strongly criticized, his influence can be sensed in Engels. While Marx had already remarked that "the philosophical moment is not the logic of the thing, but the thing of logic, $\aleph^{46}$ the main collaborator of Marx seems, at times, to go against Marx in some specific points. There is an important point to be considered here: the mode of research. Engels made a very correct point about the development of bourgeois society when he said that "by turning things into commodities, capitalist production destroyed all the old traditional relationships and replaced inherited customs and historical rights with buying and selling, with the ifree contract « ${ }^{47}$. This passage can be supported by many references in

44 Felipe Ramos Musseti, "Marx e a constituição da república francesa de I848, " Verinotio-Revista on-line de Filosofia e Ciências Humanas I9 (2015).

45 Engels stated that "it was a coincidence that Napoleon Bonaparte, precisely a Corsican, became a Military Dictator that the French Republic needed, exhausted by war. It can be demonstrated that without Napoleon, another man would have fulfilled that function given the fact that the person in question was always found as soon as it became necessary. Behold also the cases of Caesar, Augustus, Cromwell, etc. "Friedrich Engels, "Brief an Walther Borgius in Breslau (Heinz Starkenburg) (Carta a W. Borgius em Bratislava-Heinz Starkenburg de 25 de Janeiro de I894), « in $M E W_{39:} 206$.

46 Karl Marx, "Introdução," in Crítica à filosofia do direito de Hegel, transl. by Rubens Enderle and Leonardo de Deus (São Paulo, Boitempo, 2005), 39.

47 Engels, Origem da família, 93. 
Marx. However, when it comes to understanding the different ways in which "traditional relationships" are destroyed, we must highlight certain points.

The first point concerns the fact that the "traditional relations" Engels mentions still existed in various countries when he wrote the sentence cited above, and Engels was, obviously, aware of this. The second point is related to the specificity of the way in which the said process could take place under different social and historical conditions. With this point in mind, Engels said the following about the social commune and the possibility of the social development of socialism in Russia: "From India to Russia, the form of society in which this isolation predominated always found in it its complement. The Russian state, not only in general terms but in its specific form, the Czarist despotism, instead of hanging in the air, is a necessary and logical consequence of the social conditions of Russia. « $^{4^{8}}$

The first issue that stands out is the consideration of Russia and India together. When dealing with the particularity of capitalist development, Engels did not fail to consider the concrete manner in which bourgeois society developed under different conditions and historical contradictions. When dealing with the peculiarities of the countries, therefore, Engels believed that he could place India and Russia in the same field. In this way, just as the complement of the rural commune (with its relative isolation) was a manifestation in India of »oriental despotism, " the same situation would take place in the Russian context. This would happen to the extent that there would be a certain confluence between "oriental despotism« and "czarist despotism. «In other words, there seems to be a solid analysis of the immanence of the effective reality behind Engels's position, which would be focused on the fact that there would be "a necessary and logical consequence to the Russian social conditions. « And here the problems reemerge.

48 Karl Marx and Friedrich Engels, Lutas de classes na Rússia (São Paulo: Boitempo Editorial, 20I3), $5 \mathrm{I}$. 
A certain theological and logicizing tone of a Hegelian nature seems to be present in Engels's position, as he saw the Russian process as having a »necessary and logical « direction, that is, with an objective form of conformation that would not bring in any other possibilities than the development of a modern capitalist society. Later, the author would say that "the way things were, there was no alternative. «49 In other words, in view of the "laws of dialectics, " Engels may not have gone deep enough in terms of his research, and it is important to say that, against the challenges from Russian militants about the possibility to achieve socialism, Marx began to study this issue. It is also important to understand how this happened.

For us to be fair to Engels, it is necessary to say that Marx also spoke of something similar to the "laws of dialectics. "Marx made reference, in perhaps one of his most problematic texts on the situation of India in the face of British colonization, to an »immutable law of history." In other words, we cannot blame Engels for a certain slip in his exposition. When dealing with India, a country that has been invaded several times by different peoples, Marx pointed out that "according to the immutable law of history, barbaric conquerors are conquered by the superior civilization of the peoples conquered by them. "so The Indian situation, until the British invasion, would not have changed substantially since the Indian civilization was superior to that of those who had invaded the country previously. British domination, thus, despite being atrocious, would bring with it progress by making possible a rupture with a form of domination based precisely on what Engels called a combination of isolation and despotism, providing, in the late development, the foundations for the demise of British - and capitalist-domination in the Indian territory. Marx, therefore, does not seem to simply "apply" the "laws of dialectics." Even if his diction is problematic, we can see that immanence already appears insofar as "history" and »dialectics» are not separated, tak-

49 Ibid., I39.

50 Karl Marx and Friedrich Engels, Acerca del colonialismo (Buenos Aires: Editorial Utopia Libertaria, 2009), 48. 
ing into account the specificity of the Indian case, as opposed to the advance of capitalism in a typical form, as happened in England. In other words, historical development is uneven, and we always have to take into account the objectivity and historicity of the social being himself, with praxis being the criterion for obtaining them, so much so that Marx clearly highlighted the following with regard to primitive accumulation: ${ }^{\text {s }}$

The chapter on primitive accumulation aims exclusively at delineating a route through which, in Western Europe, the capitalistic order emerged from the bowels of the feudal economic order. Therefore, it accompanies the movement that divorced the producer from his means of production, transforming the former into a wage earner (a proletarian in the modern sense of the word) and the latter into ${\text { capital. } .^{2}}^{2}$

At the same time that Marx mentioned the »immutable law of history, « he stressed that the way in which bourgeois society placed itself in Capital only took Western Europe into account and, therefore, not India or Russia. In this sense, in order to deal with these two countries, careful research was necessary before a judgment could be made about the peculiarity of the historical development of each one. ${ }^{53}$ Thus, there is an intimate relationship between that which is placed in a quite large degree of generality and the particular cases; however, we can never ignore any of these aspects. According to the German author, in some cases they could be

5I Primitive accumulation got underway in India through colonialism, and it was a possibility in Russia in the face of the disintegrating tendencies that tried to impose themselves upon the Russian commune.

52 Marx and Engels, Lutas de classes, 66

53 On this point, the use of quotation marks is essential: "The historical fatalism of this movement is restricted to the countries of Western Europe.« Ibid., 89. 
[e]vents of a striking analogy but which take place in different historical environments leading to totally different results. When you study each one of these developments separately, we can easily figure out the key to this phenomenon. However, we will never arrive at this with a historical-philosophical master key whose supreme virtue consists of being supra-historical..$^{54}$

Sometimes there would be "different historical environments leading to totally different results, « and in these cases, it must be said, Marx disagreed with Engels on this point about Russia: while Engels took India and Russia together, that is not what Marx did in Capital, which was emphatic about the prospect of a distinct development of Russia, which had the possibility of a direct transition to socialism from the rural commune. 55

The Russian situation would be different in that the peasantry itself would not be marked by private ownership of the means of production. In England, »in the final analysis, there is a transformation of one form of private property into another form of private property. The land in the hands of Russian peasants has never been their property. $11^{66}$ There would also be the permanence of the rural commune in the middle of the capitalist development that would be inseparable from Russia, and thus, for reasons that we cannot go into here, Marx said that "it can, therefore, become the direct starting point of the economic system towards which modern society drifts and sheds its skin without having to commit suicide. " $\$ 7$ In other words, in view of the uneven development of the history of capitalist society, not only would it be impossible to homogenize solutions to the problems of bourgeois society,

54 Ibid., 69.

55 After much study, Marx pointed out that "the conclusion at which I arrived is the following: If Russia continues to pursue the path she has followed since I86I, she will lose the finest chance ever offered by history to a nation, in order to undergo all the fatal vicissitudes of the capitalist regime.« Ibid., 66.

56 Ibid., 89.

57 Ibid., Ioo. 
it would also be a matter of apprehending the real and effective fabric and particularity of each social formation, thus making it necessary to be very careful in one's research, which would imply the impossibility of predictions of or narrative concatenations that did not have solid support in the historicity and the objectivity of the social being. With this, Marx again distinguished himself from Engels by bringing greater care to these issues: in the face of this uneven development, he tried to delineate the difference between India and Russia in a rigorous and cautious way. First, he highlighted the "contemporaneity of the capitalist production: it is precisely thanks to the contemporary nature of capitalist production that it can appropriate all positive achievements, and this without going through its unpleasant vicissitudes." Subsequently, he emphasized how this had implications, pointing out that »Russia does not live isolated from the modern world, nor was it the victim of a foreign conqueror, as were the East Indies. $~^{58}$ In this sense, there is very special care with regard to research, something that, of course, Engels always had in mind but could not always put into practice with the necessary diligence (it is perhaps possible to point out some slightly hurried generalizations even in the classic The Origin of the Family, Private Property and the State).

In this short contribution, we have made some notes about the theorizing of Engels on "methodological» aspects. These aspects, apparently irrelevant when dealing with analyses of conjecture or political positions, proved decisive in the end. Even when it comes to one of the greatest confluences in the history of social thought (the one between Marx and Engels), the question arose in a strident manner. To the extent that the authors shared substantive positions, it was possible to see how a conception of dialectics and history that barely differs in some points can effectively bring forth different concrete positions to the surface. In view of these positions, we notice that, in Marx, research was essential, and the exposition was realized with difficulty, seeking to express in the best possible way that which was obtained through

58 Ibid., 90. 
careful research. In Engels, of course, there was never any deliberate neglect with regard to research or seeking objective concatenations present in the effective reality itself; nevertheless, using a certain tone, sometimes logical, and supported by the "laws of dialectics, " the German philosopher may have stumbled at times. This happened with regard to the mode of exposition, which tends to be too systematic in some of its essential points (and this may have given rise to no less than a century of vulgar "Marxism»), as well as with regard to the method of research that, in the face of certain previous systematic treatments, may have been neglected at times. Such tension, from what we have seen, is the concrete expression of a certain Engelsian treatment that brings with it a conflicting relationship between an exposition that, at certain moments, borders on the gnoseological understanding of the method and a concrete position that seeks, with care, to deal with the real fabric of the effective reality. Thus, if Engels pointed out in Hegel a "contradiction between system and method, " certain "contradictions" can perhaps be pointed out in the author of Anti-Dühring. This does not diminish his merits in the least; it only gives a necessary warning to all those who look at Marx's and Engels's texts as sources of assistance in the determined critique of capitalist society. Even if Engels was rushed at times, for us, self-criticism is, and always will be, essential.

\section{Translated by Gilmar Visoni-Alonzo}

\section{Works Cited}

Arantes, Paulo. Hegel e a ordem do tempo. São Paulo: Hucitec, 1982.

Chasin, José. Marx: estatuto ontológico e resolução metodológica. São Paulo: Boitempo, 2009.

Engels, Friedrich. Do socialismo utópico ao socialismo científico \& Ludwig Feuerbach e o fim da filosofia clássica alemã. Translated by José Severo de C. Pereira. São Paulo: Fulgor, 1962. 
-. "Brief an Walther Borgius in Breslau (Heinz Starkenburg) (Carta a W. Borgius em Bratislava-Heinz Starkenburg de 25 de Janeiro de I894). «In Marx/Engels Werke Vol. 39. Berlin: Dietz Verlag, 1968.

—. Dialética da natureza. Rio de Janeiro: Paz e Terra, 1979.

—. Anti-Dühring. Rio de Janeiro: Paz e Terra, 1990.

-. Origem da família, da propriedade privada e do estado. Translated by Ruth M. Klaus. São Paulo: Centauro, 2002.

Engels, Friedrich and Karl Kautsky. O socialismo jurídico. Translated by Márcio Naves and Lívia Cotrim. São Paulo: Boitempo, 2012.

Gramsci, Antonio. Maquiavel: notas sobre o estado e a política. Cadernos do cárcere vol. III. Translated by Carlos Nelson Coutinho. Rio de Janeiro: Civilização Brasileira, 2002.

Hegel, Georg. Princípios da filosofia do direito. Translated by Orlando Vittorino. São Paulo: Martins Fontes, 2003.

Löwy, Michel. As aventuras de Karl Marx contra o Barão de Münchhausen. São Paulo: Cortez, 1994.

Lukács, György. El joven Hegel y los problemas de la sociedad capitalista. Translated by Manuel Sacristán. México: Grijalbo, 1963.

- História e consciência de classe. Translated by Rodnei Nascimento. São Paulo: Martins Fontes, 2003.

-. Prolegômenos para uma ontologia do ser social. Translated by Lya Luft and Rodnei Nascimento. São Paulo: Boitempo, 2010.

Marx, Karl. Grundrisse der Kritik der politichen ökonomie. Berlin: Dietz Verlag, 1953 .

—. »Kritik des Goethaer Programms."In Marx/Engels Werke Vol. Ig. Berlin: Dietz Verlag, 1962.

-. O capital bk. I, vol. I. Translated by Régis Barbosa and Flávio R. Kothe. São Paulo: Nova Cultural, 1988.

—. Grundrisse. Translated by Martin Nicolaus. London: Penguin Books, 1993.

- O capital bk. I, vol. II. Translated by Régis Barbosa and Flávio R. Kothe. São Paulo: Nova Cultural, 1996.

-. O I8 Brumário de Luis Bonaparte. Translated by Leandro Konder and Renato Guimarães. Rio de Janeiro: Paz e Terra, 1997.

-. "Introdução." In Crítica à filosofia do direito de Hegel. Translated by Rubens Enderle and Leonardo de Deus. São Paulo, Boitempo, 2005. 
-. Contribuição à crítica da economia política. Translated by Florestan Fernandes. São Paulo: Expressão Popular, 2009.

-. Grundrisse. Translated by Mário Duayer. São Paulo: Boitempo, 20 oII.

—. O capital. Translated by Rubens Enderle. São Paulo: Boitempo, 2013.

Marx, Karl and Friedrich Engels. „Die deutsche Ideologie.» In Marx/Engels Werke Vol. 3. Berlin: Dietz Verlag, 1968.

—. A ideologia alemã. Translated by Luís Cláudio de Castro e Costa. São Paulo: Martins Fontes, 200I.

—. A ideologia alemã. Translated by Rubens Enderle. São Paulo: Boitempo, 2007.

-. Acerca del colonialismo. Buenos Aires: Editorial Utopia Libertaria, 2009.

-. Cultura, arte e literatura: textos escolhidos. Translated by José Paulo Netto. São Paulo: Expressão Popular, 2010.

-. Lutas de classes na Rússia. São Paulo: Boitempo Editorial, 2013.

Musseti, Felipe Ramos. "Marx e a constituição da república francesa de I848." Verinotio-Revista on-line de Filosofia e Ciências Humanas I9 (2015): I44-I59.

Salgado, Joaquim Carlos. A ideia de justiça em Hegel. Petrópolis: Loyola, 1996. Sartori, Vitor Bartoletti. »De Hegel a Marx: da inflexão ontológica à antítese direta." Kriterion 55, no. I30 (2014): 69I-713.

Vaisman, Ester. "A ideologia e sua determinação ontológica."Verinotio-Revista on-line de Filosofia e Ciências Humanas I2 (2010): 40-64. 


\title{
Friedrich Engels and Revolution Theory

\author{
The Legacy of a Revolutionary Life
}

\author{
Frank Jacob
}

\section{Introduction}

Friedrich Engels was a revolutionary by heart, who never, although having witnessed failed revolutions in I848 and I87I, gave up believing in its final success. He might have considered himself as second fiddle to Karl Marx, ${ }^{\mathrm{I}}$ but when it comes to the study and the attempt to theoretically explain revolutions as a phenomenon of modernity and the final aim of the communist movement, he was as important as his friend, and together, these "revolutionary twins $\aleph^{2}$ were actively involved in finding an explanation for the course of revolutionary processes. Their contemporaries considered Engels to be Marx's alter ego, ${ }^{3}$ and it is true that both of them shared many thoughts, although the latter would remain the more important, at least with regard to the consciousness of the masses. Nevertheless, Engels not only played an important role in the intellectual development of Marx, he can and also should be taken seriously as an intellectual of great ability. ${ }^{4}$ The rise of Marx as one of

I Sigmund Neumann and Mark von Hagen, "Engels and Marx on Revolution, War, and the Army in Society, " in Makers of Modern Strategy from Machiavelli to the Nuclear Age, ed. Peter Paret (Princeton, NJ: Princeton University Press, 1986), 264.

2 Oscar J. Hammen, „Alienation, Communism, and Revolution in the Marx-Engels Briefwechsel, "Journal of the History of Ideas 33, no. I (1972): 80.

3 J. D. Hunley, Life and Thought of Friedrich Engels: A Reinterpretation of His Life and Thought (New Haven, CT: Yale University Press, I99I), 47.

4 Samuel Hollander, Friedrich Engels and Marxian Political Economy (Cambridge: Cambridge University Press, 20II), 279-3I3. 
the most well-known intellectuals of the Igth century was without any doubt only possible due to the support of Engels, who, as the economist Samuel Hollander emphasizes, was "more royalist than the king "s and promoted and even finished important parts of Marx's own work. Many of the latter's texts would not have existed without Engel's influence, and the textual production of Marx and Engels was a cooperative venture most of the time. When Marx was invited to write articles for the New York Daily Tribune, Putnam's Monthly, and The New American Cyclopaedia, Engels translated some of his friend's texts and also gave him material that was eventually published under the former's name. ${ }^{6}$ And Capital, especially volumes 2 and 3, would never have seen the light of day without the hard work of Engels. ${ }^{7}$

Whenever Marx needed advice, he would consult Engels, who also supported his friend financially for many years. ${ }^{8}$ The former was thankful for this support, as he highlighted in a letter to Engels on 7 May I867: "Without you, I would never have been able to bring the work to completion, and I assure you, it has always weighed on my conscience like an Alp that you have dissipated your splendid energy and let it rust on commercial matters, principally on my account, and into the bargain, still had to participate vicariously in all my minor troubles. $\ll^{9}$ It is ironic that Engels was accused by many scholars, and Marxists in particular, for having revised Marx's intentional ideas and therefore paved the way for all the misery that has been caused by dogmatic Marxism in the years ever since. ${ }^{10}$ Hence, and regardless of such criticism, Engels, especially 200 years after his birth, needs to be reconsidered and deserves to be treated as equally important as Marx. Considering the number of works this »open-minded, experimental,

$5 \quad$ Ibid., 279.

6 Hunley, Life and Thought, I27.

7 Ibid., I37.

8 Ibid., I34.

9 Cited in ibid., 138.

Io Ibid., 96. 
heretical thinker «" has left, it is very much worthwhile to have a closer look at his thoughts, especially since the historical interpretations of "Marxian theory" are related to his ideas and attempts to better understand the world and the forces that created it. ${ }^{\mathrm{I}}$

It should be taken into account that Gustav Mayer's biography is still one of the best about Friedrich Engels; ${ }^{13}$ however, his life and work have unfortunately not attracted as much attention as those of Marx. Of course, most of these writings "were carried out as part of a mutual collaboration with Marx, ${ }^{14}$ but there are "increasing attempts to view and treat Engels as separate and apart from Marx." Although Indian politician and intellectual Rustam Singh argued that " $[\mathrm{t}]$ here may be some merit in these attempts, but, in our view, the separation creates more problems than it solves, «" it seems to be valuable to take a closer look at Engels, especially when one dives into revolution theory in relation to Marxism. Naturally, and due to the mentioned working process the two intellectuals applied, "to study Engels separately ... represents a very difficult task. ${ }^{16}$ Martin Berger also remarked with regard to the overlap of ideas in the collected works of Marx and Engels that "[i]n the background of most studies of Marx and Marxism lurks the pale figure of Fried-

II Gert Schäfer, „Friedrich Engels: Builder of Closed Systems? « Science \& Society 62, no. I (1998), Friedrich Engels: A Critical Centenary Appreciation: 35.

I2 Eric R. Wolf, »The Peasant War in Germany: Friedrich Engels as Social Historian, «Science \& Society 5I, no. I (1987): 82.

I3 Gustav Mayer, Friedrich Engels: Eine Biographie, 2 vols. (Berlin: Springer, 1920-1933). For an early review of vol. I see Hermann Oncken, „Friedrich Engels und die Anfänge des deutschen Kommunismus, " Historische Zeitschrift I23, no. 2 (I92I): 24I-242.

I4 Elvira Concheiro, "A Century after His Death: Friedrich Engels and the Concept of Political Parties, "Science \& Society 62, no. I (1998), Friedrich Engels: A Critical Centenary Appreciation: I64.

I5 Rustam Singh, "Status of Violence in Marx's Theory of Revolution, "Economic and Political Weekly 24, no. 4 (1989): 9. A similar view is expressed in Edmund Silberner, The Problem of War in Nineteenth Century Economic Thought (Princeton, NJ: Princeton University Press, 1946), 25I.

I6 Concheiro, "A Century after His Death, « I64. 
rich Engels. When a suitable Marx quotation fails to come to hand to illustrate a point, Engels can always fill in; thus most works on Marx and his Ism are really studies of Marxandengels. So close was the partnership of the two that it is virtually impossible to do Marx without including Engels. « ${ }^{17}$

However, considering that both men remained individuals and worked in their own fields of interest as well, one cannot simply declare all of Engels's work to be based on Marx's ideas and vice versa. ${ }^{18}$ Engels also remained the first and probably most important critic of his friend, and as Oscar J. Hammen put it, »Engels frequently enough was critical of Marx's findings, but there is no evidence of a disturbing conflict of views. Marx, in turn, never hesitated to alter or reject the draft of an article by Engels - on one occasion even because the item was not written in the customary reasygoing` (sic) style, when a question of popularization was in the picture. ${ }^{19}$ All in all, the two men lived and worked as equal partners, who still had their own ideas and projects, which they, however, would share and discuss with each other. They also profited from each other, not only financially, but first and foremost intellectually, a fact that made their "company-business « so successful and productive for so many years. ${ }^{20}$ In contrast to Marx, whose economic work is that of a genius, Engels did not limit himself to one field of study, and, just as his intellectual sources may

I7 Martin Berger, "Disentangling Engels from Marxandengels, "International Labor and Working-Class History I2 (1977): 4I.

I8 Hans Peter Bleuel, Friedrich Engels: Bürger und Revolutionär (Bern/Munich: Scherz, 198I), William O. Henderson, The Life of Friedrich Engels, 2 vols. (London: Frank Cass, 1976), Tristram Hunt, Friedrich Engels: Der Mann, der den Marxismus erfand, transl. by Klaus-Dieter Schmidt, third edition (Berlin: List, 2020), and Norman Levine, The Tragic Deception: Marx contra Engels (Santa Barbara/Oxford, Clio Books, 1975) tried to provide a more separated view of Engels's life.

I9 Hammen, "Alienation, Communism, and Revolution," 79. Also see Erhard Lucas, "Marx` und Engels's Auseinandersetzung mit Darwin: Zur Differenz zwischen Marx und Engels, "International Review of Social History 9, no. 3 (1964): 433-434.

20 Hammen, "Alienation, Communism, and Revolution, " 79 and 82. 
have been diverse, ${ }^{2 \mathrm{I}}$ so too were his writings with regard to the topics he covered. ${ }^{22}$ The two men were, however, not static in their thinking, but, as American historian Leonard Krieger (1918-1990) remarked, »it has been recognized that the passion for the comprehension of facts which drove Marx and Engels from the Hegelian dialectic to dialectical materialism drove them at the same time to a search for a command over historical and social knowledge. ${ }^{23}$ Their result was a new way to explain and understand historical processes, a method that went away from the great men who determined human history and important events that changed the course of the world. They explained history as being related to class and class conflict, and therefore to the masses of the people. ${ }^{24}$

When we talk about a Marxist-Engelsian approach towards history, we talk about revolutionary history, something especially Engels outlined in his many works. ${ }^{25}$ Because communism, as Marx and Engels understood it, "sought to stand up for and with all the world's oppressed peoples, especially its workers, who were being crushed under the wheels of industrialization, privatized greed, and a ruling elite's attempt to monopolize wealth, ${ }^{26}$ it is not surprising that they looked at the history of the people's struggle against exploitation as well. According to their interpretation, i. e. historical materialism, »[t] hese two men believed that all human history was leading inevitably to a class-based warfare that would result in the violent overthrow of the upper classes by the working class. ${ }^{27}$ Engels, due to the existent

2I Karl A. Wittfogel, »The Marxist View of Russian Society and Revolution, "World Politics I2, no. 4 (1960): 487.

22 Martin Berger, "Engel's Theory of the Vanishing Army: A Key to the Development of Marxist Revolutionary Tactics, "The Historian 37, no. 3 (1975): 422.

23 Leonard Krieger, "Marx and Engels as Historians, "Journal of the History of Ideas I4, no. 3 (I953): 382 .

24 Jonathan Joseph, Social Theory: Conflict, Cohesion and Consent (Edinburgh: Edinburgh University Press, 2003), 6 and 9-15.

25 Krieger, "Marx and Engels as Historians, « 383.

26 John Murphy, ed. Socialism and Communism (New York: Britannica Educational Publishing, 2015), $x$.

27 Ibid., xi-xii. 
situation in the late 1840 s, also focused on social groups rather than political organizations when he considered the form and course of the revolutionary process that would supposedly follow in the near future. ${ }^{28}$ However, Engels was also aware that the existent conditions would play an important role in any revolution and therefore, not surprisingly, changed his ideas about the revolution to come, although not his belief that it would eventually change the world. He considered revolutionary processes to act according to natural law, and in a letter to Marx in February I85I, Engels wrote: „A revolution is a pure phenomenon of nature, which is led more according to physical laws than according to the rules which in ordinary times determine the development of society. Or rather, these rules take on a much more physical character in revolution; material power emerges much more violently. «9 $^{29}$

Since Marx and Engels, as historians, included their own experiences in relation to the revolutionary events of the igth century when they discussed the revolution of the future, they also pointed out the social and political shortcomings of a century in which the masses began to demand more power from those who had determined the latter's fate for so long..$^{30}$ The evaluation of bourgeois and proletarian revolution, as well as the interrelationship between the two, was a process for Marx and Engels, in which they changed their opinion multiple times, as they could observe failed revolutionary attempts over a long period of time. The two revolutionaries could look back on the events of $1848 / 49$, and they also knew about the Great French Revolution. Therefore, they could base their theoretical assumptions on actual historical knowledge, although the failures of the past did not limit their revolutionary enthusiasm for the future. ${ }^{3 \mathrm{I}}$ Like Marx

28 Krieger, "Marx and Engels as Historians, « 388.

29 Cited in ibid., 392.

30 David Leopold, "The Structure of Marx and Engels's Considered Account of Utopian Socialism, "History of Political Thought 26, no. 3 (2005): 466.

3I Martin Hundt, "Zur Entwicklung der marxistischen Revolutionstheorie nach der Revolution von I848/49, "Marx-Engels-Jahrbuch Io (I986): 3I. 
and Engels, we have to be careful when we discuss revolutions in retrospect and consequently have to analyze them in their historical context. ${ }^{32}$ In the case of the two famous revolutionaries, this means that their ideas were the scientific condensation of actual experiences related to the revolutionary process of I848/49. The witnessing of the failed revolution would determine the scientific condensation of their thoughts about future revolutions, ${ }^{33}$ a process not only Marx and Engels went through. While theoretical works about the formation of Marxist revolution theory were legion in an East German context, ${ }^{34} \mathrm{a}$ detailed analysis of Engels's works and his thoughts on revolution as a phenomenon of modernity has not really been of interest since the end of the Cold War, although some reflections were provided by historian Martin Hundt in 1986. Hundt also argues that Engels's revolution theory could not ignore his actual experience of the revolution in I848/49 and, like other revolution theories, was the consequence of historical developments witnessed by the author of such theoretical reflections. ${ }^{35}$ The Communist Manifesto (I848) was consequently the attempt to provide a solid revolution theory for the first time; however, it would have to be proven by historical developments, ${ }^{36}$ and due to the many failed revolutions that would follow in the igth and 20 th centuries, it was redefined and reconfigured by other revolutionaries

32 Manfred Kossok, "Revolution und Weltgeschichte im Werk von Walter Markov, « in Walter Markov, Weltgeschichte im Revolutionsquadrat, ed. and introduced by Manfred Kossok (Berlin: Akademie-Verlag, 1982), ix.

33 Hundt, "Zur Entwicklung, " 3I.

34 Wolfgang Eichhorn, "Gesetzmäßigkeit von Revolutionen, "Sitzungsberichte der Akademie der Wissenschaften der DDR. Gesellschaftswissenschaften II (1984); Ernst Engelberg and Wolfgang Küttler, eds. Formationstheorie und Geschichte: Studien zur historischen Untersuchung von Gesellschaftsformationen Werk von Marx, Engels und Lenin (Berlin: Akademie-Verlagm 1978); Manfred Kossok, ed. Studien über die Revolution (Berlin: Akademie-Verlag, 1969); Manfred Kossok and Walter Markov, eds. Studien zur vergleichenden Revolutionsgeschichte I500-I9I7 (Berlin: Akademie-Verlag, 1974).

35 Hundt, "Zur Entwicklung, " 33-34.

36 Ibid., 34 . 
who turned Marxism into a new form of historical interpretation, e. g. Leninism or Maoism.

Regardless of such later changes, the present chapter intends to take a closer look at Friedrich Engels's writings and ideas about revolution. First, however, a look at his life as a revolutionary shall be taken in order to explain where his ideas originated from. In the second part, the chapter will then pay close attention to some texts by Engels in which he develops his ideas in relation to a revolution he believed would soon change the world. It is important to understand that Engels did not create a static revolution theory, but rather tried to adjust his thoughts over a long period of time to match the existent preconditions. He nevertheless was a true believer in revolution and never gave up on preparing himself and society for a tremendous transformation that would soon take place. Unfortunately, Engels and his ideas were often used as a scapegoat to explain the failures of revolutionary processes in the 2oth century when Marxist ideas about revolution and decontextualized quotes from Marx and Engels were used to make arguments on behalf of corrupted revolutionary governments, whose leaders claimed to rule only in the sense of Marx and Engels and at the same time promised a new and better world. ${ }^{37}$ This was probably also possible due to the fact that Engels in particular had written about the revolution in different tones at different times. His revolution theory was a work in process and therefore must be understood as something that might have fitted into the igth century but could not be applied to the events of the 2oth century without further processing. Regardless of this fact, however, Engels's writings about revolution are important to understand this global phenomenon of modernity a bit better, and those interested in revolution theory and its application in the 2Ist century should be encouraged to pay close attention to these writings to better understand revolutionary processes, and especially the dangers related to them.

37 Frank Jacob, I9I7: Die korrumpierte Revolution (Marburg: Büchner, 2020). 


\section{The Revolutionary Life of Friedrich Engels}

Engels was interested in philosophy from early on,$^{38}$ which probably revolutionized his mind and made him aware of the problems of his time. ${ }^{39}$ When he first arrived in England in 1842 to work in the cotton business of his father, Engels already, to quote British historian Gregory Claeys, "considered himself as something of a revolutionary, " and when considering his early writings, including The Condition of the Working Class in England (1845), it seems clear »that he expected and desired a revolution to take place there. « $^{\circ}$ When he met Marx for the first time at the Rheinische Zeitung in 1842, Engels had probably been more revolutionary than his future friend and companion, and it is not surprising that his revolutionary ambitions were even intensified by his experiences in Manchester between 1842 and $1844 .{ }^{41}$ It was the British industrial center that offered Engels a deeper insight into the functioning of industrial capitalism, and the exploitation and poverty of the working class he observed there would turn the young capitalist into a socialist revolutionary. In August I844 he met Marx again, this time in Paris, where the latter worked on the Deutsch-Französische Jahrbücher, and the two men eventually forged their friendship while discussing their theoretical ideas for ten days. ${ }^{42}$ Engels would become one of the few people Marx accepted as intellectually equal, and the

38 Georges Labica, "Engels and Marxist Philosophy, "Science \& Society 62, no. I (1998), Friedrich Engels: A Critical Centenary Appreciation: 13-34.

39 Narihiko Ito, "Realismus und Utopismus, " in Zwischen Utopie und Kritik: Friedrich Engels_ein "Klassiker" nach Ioo Jahren, eds. Theodor Bergmann, Mario Keßler, Joost Kircz and Gert Schäfer (Hamburg: VSA, 1996), 23-33.

40 Gregory Claeys, "The Political Ideas of the Young Engels, I842-I845: Owenism, Chartism, and the Question of Violent Revolution in the Transition from 'Utopian to 'Scientific Socialism, " History of Political Thought 6, no. 3 (I985): 457.

4I Philip Erbentraut and Torben Lütjen, »Eine Welt zu gewinnen: Entstehungskontext, Wirkungsweise undNarrationsstruktur des `Kommunistischen Manifests`, in Manifeste: Geschichte und Gegenwart des politischen Appells, eds. Johanna Klatt and Robert Lorenz (Bielefeld: Transcript Verlag, 20IO), 77.

42 Friedich Engels, "Zur Geschichte des Bundes der Kommunisten, « in Marx-EngelsWerke (Berlin: Dietz, I956-, henceforth $M E W$ ), 2I: 2 I2. 
following years would show that the two were quite good at working as a productive joint venture. On the other hand, Engels worshipped Marx and often agreed to work for his friend instead of following his own interests to a larger extent. ${ }^{43}$

In his spare time, however, Engels worked extensively on many other things than just economic questions. One field he was particularly interested in was military matters, ${ }^{44}$ and he not only studied military history but also strategy and tactics, although Engels would also set his knowledge about military affairs in the context of his revolutionary ambitions and reflections about the revolution he hoped to witness soon, despite the failure of that of $1848 / 49.45$ In military science, it was therefore Engels who "was the dominant member of the Marx-Engels partnership, " and it was not only there but in many other relevant fields of his expertise that "he was the originator, not merely a popularizer or vulgarizer of Marx's ideas. $\aleph^{46}$ The famous German revolutionary also steadily combined his knowledge in military affairs with his revolution theory, e.g. his Theory of the Vanishing Army, and was therefore able to understand revolutionary processes in their full complexity. His studies in relation to different military matters consequently "shaped the classical Marxist approach to the timing and tactics of revolution. « ${ }^{47}$ This also becomes obvious due to the fact that Engels had had some experiences during the Revolution of I848 when he was actively involved in the fight against the European reaction, which he would later reflect upon in his writings about revolution: »Revolutions, Engels said, produced confusion, and confusion

43 Erbentraut and Lütjen, »Eine Welt zu gewinnen, « 78 .

44 For a detailed discussion see Jehuda L. Wallach, Die Kriegslehre von Friedrich Engels (Frankfurt am Main: Europäische Verlagsanstalt, 1968); Gerhard Zirke, Der General: Friedrich Engels, der erste Militârtheoretiker der Arbeiterklasse (Leipzig: Urania-Verlag, 1967).

45 Berger, "Engel's Theory of the Vanishing Army, « 42I-422; Martin Kitchen, „Friedrich Engels's Theory of War, " Military Affairs 4I, no. 3 (I977): II9; Wittfogel, "The Marxist View, « 489.

46 Berger, "Engel's Theory of the Vanishing Army, 422.

47 Ibid. 
did not promote military efficiency. Unorganized enthusiasm would not win battles. $\aleph^{48}$ With regard to the growing militarism in Europe, Engels also predicted that this would lead to revolution, ${ }^{49}$ although, in contrast to his assumptions, such revolutions, e.g. in Russia in 1917 or Germany in 1918, would not change the world and end capitalism.

Due to his experience of the failed Revolution of I848, it seemed clear that the revolution of the future needed to be better prepared, and tactical considerations, including those about the military and its role during such a revolutionary process, were quite prominent in Marx's and Engels's writings of later years. ${ }^{5 \circ}$ Engels, in particular, "expressed increasing revulsion at the prospect of a future world war, which threatened to destroy all the advances made not only by the working class and by socialist movements, but by Western civilization itself. " increase in revolutionary potential in the late 1850 . In I857 he wrote to Marx that "[a] continuing economic depression could be used by astute revolutionary strategy as a useful weapon for a chronic pressure ... in order to warm up the people ... just as a cavalry attack has greater elan if the horses trot five hundred paces before coming within charging distance of the enemy. ${ }^{\varsigma^{2}}$ Engels consequently included his own observations in his reflections about the future revolution. This also highlights that Engels's revolution theory was a process based on his everyday life experience since the I840s. The theory, therefore, cannot be considered as absolute, but rather a work in progress. In the 2Ist century, this means that Engels's assumptions can be accepted as a theoretical base or framework, which, nevertheless, needs to be adjusted to the present-day context.

48 Ibid., 425 .

49 See for example Engels's preface to The Capital (1886) or Friedrich Engels, Herr Eugen Dühring's Revolution in Science (Anti-Dühring) (New York: International Publishers, 1939), I89-190.

50 Neumann and von Hagen, »Engels and Marx on Revolution, 262.

$5 \mathrm{I}$ Ibid.

52 Cited in ibid., 263. 
Marx and Engels understood that their theoretical approach to understand the world and to prepare the revolution of the future needed to include multiple aspects, e.g. economic development, foreign policy, military affairs, etc. In addition, they realized, to quote Sigmund Neumann and Mark von Hagen once more, "that the future of the European revolution would not be determined by the efforts of one country alone. This realization directed their attention to a serious consideration of the relationships between socialism, military policy, and foreign affairs, because without an understanding of these relationships a realistic revolutionary strategy could not be possible. «3 At the same time, both tried to criticize the existent order for its shortcomings and the existent stumbling blocks that prevented people from realizing the necessity of revolution..$^{54}$ Regardless of such criticism, Marx and Engels were in favor of nationalism as well, as long as it was directed towards their favored goals, e. g. the unification of Germany and Italy or Polish independence from Russia.s

Regardless of such aspects related to the revolutionary thoughts of the two men, it was the experience of $1848 / 49$ that first and foremost defined the theoretical reflections of Marx and Engels, who, due to the outcomes of the European revolution in these years, accepted the lessons and necessities for a new and inevitable revolutionary attempt in the near future: »Equally inevitable [as another revolution] was the violent nature of this revolution. This inevitability of the revolution and its violent nature was determined by the very structures of the bourgeois system. Marx and Engels concluded this on the basis of their analysis of the historical forces and the then existing social relations, and of the nature of private property. ${ }^{56}$ For Marx and Engels,

53 Ibid., 264.

54 For Engels's views on religion see Michael Löwy, "Friedrich Engels on Religion and Class Struggle, « Science \& Society 62, no. I (1998), Friedrich Engels: A Critical Centenary Appreciation: 8I.

55 Horace B. Davis, "Nations, Colonies and Social Classes: The Position of Marx and Engels, «Science \& Society 29, no. I (1965): 27; Iring Fetscher, »Friedrich Engels, Polen und der Russische Imperialismus, "Osteuropa 7, no. 6 (I957): 43 I.

56 Singh, "Status of Violence, « 9. 
it was clear that " $[\mathrm{t}]$ he revolution is necessary ... not only because the ruling class cannot be overthrown in any other way, but also because the class overthrowing it can only in a revolution succeed in ridding itself of all the muck of ages and become fitted to found society anew. ${ }^{57}$ Further studies and experiences, however, made the two men rethink their attitude towards violence. In some political systems, a peaceful change, i. e. the working masses gaining the popular vote in the elections and the popular vote, seemed at least possible, although the rrevolutionary twins» emphasized »that the working class should not forego its right to use violent methods even at such places because the ruling classes could not be expected to give up their power, even here, without an armed resistance. ${ }^{8} 8$

In February 1848, Engels was more than enthusiastic about the revolution and was sure that it would bring the anticipated changes with it in no time.99 Well aware of the history of the French Revolution, however, Marx and Engels had to witness how the Revolution of I 848 was corrupted similarly to the French Revolution of I789 and ended with a Bonaparte ruling France again. Marx, in The Eighteenth Brumaire of Louis Bonaparte (I852), commented on this fact as follows: "Hegel remarks somewhere that all great world-historic facts and personages appear, so to speak, twice. He forgot to add: the first time as tragedy, the second time as farce. ${ }^{60}{ }^{60}$ The revolutionary process seemed to have repeated the doomed course of that of $1789 .{ }^{61}$ As participants, nevertheless, Marx and Engels had tried to influence the course of the

57 Karl Marx and Friedrich Engels, The German Ideology (Moscow: Progress Publishers, 1976), 60, cited in ibid.

58 Ibid., I8.

59 Christopher Andrew, Secret World: A History of Intelligence (New Haven, CT: Yale University Press, 2018), 386.

60 Karl Marx, The Eighteenth Brumaire of Louis Bonaparte (I852). Accessed August 20, 2020. https://www.marxists.org/archive/marx/works/1852/18th-brumaire/.

6I Bernard H. Moss, "Marx and Engels on French Social Democracy: Historians or Revolutionaries?" Journal of the History of Ideas 46, no. 4 (I985): 54I. For a discussion of generic revolutionary processes and the danger of them being corrupted see Jacob, 1917 . 
revolution and lead it to a positive outcome. Marx left Paris for Cologne, where he worked as the editor of the Neue Rheinische Zeitung that was launched on I June I848. Engels later emphasized that the journal was led by his friend like a dictator, but he was able to achieve a circulation of 5,000 issues of the paper, which was quite impressive for the time. ${ }^{62}$ Despite their involvement, their attempt to radicalize the revolutionary process, and their hopes for a real change as a consequence, the revolution lost its dynamic, and it seemed impossible to achieve the changes that had been demanded by the representatives of the international proletariat. ${ }^{63}$ The revolution remained unfulfilled, a half one, and the revolutionaries failed to overthrow the bourgeois elites who continued to determine the fate of the single nation states.

For the moment, it seemed clear that the hopes and aims of Marx and Engels would remain long-term goals, while the former coined the idea of a revolution in permanence (Revolution in Permanenz) in March I850. ${ }^{64}$ This concept would be essential for the further study of and discussions about revolutions, and it was particularly necessary because the revolution of 1848 had unexpectedly strengthened the counter-revolutionary forces across Europe. Very soon after its appearance, " $[\mathrm{t}]$ he revolutionary momentum faded away without visible result, $"{ }^{65}$ although the many military struggles had turned Europe into the battlefield of a civil war-like conflict about the future and a vision for modernity. It was the eventual failure of this revolutionary attempt that demanded an explanation and therefore stimulated the further development of a scientific form of socialism. Marx and Engels would work on this specific issue in their post-revolutionary exile. One of their assumptions in relation to their studies was the fact

62 Andrew, Secret World, 387.

63 Peter Stadler, "Wirtschaftskrise und Revolution bei Marx und Engels: Zur Entwicklung ihres Denkens inden I850er Jahren, Historische Zeitschrift 199, no. I (I964): II3.

64 Ibid., II4; Erik van Ree, "Marxism as Permanent Revolution, « History of Political Thought 34, no. 3 (2013): 540.

65 Neumann and von Hagen, "Engels and Marx on Revolution, 266. 
that a crisis was considered to be a necessary $\operatorname{trigger}^{66}$ for every future revolution to begin, and when the European economies seemed to be under pressure in 1857 , they had hopes that "the European reaction would give way to a new revolutionary situation. Engels was delighted by the thought that he might soon be able to leave business for the battlefield and his office stool for a horse. ${ }^{67}$ In addition to their scientific approach to the study of revolutions, Marx and Engels, as a consequence of their experiences of 1848 , interpreted history as such as a permanent class struggle. ${ }^{68}$ Alongside this conclusion, Engels also realized the important interrelation between war and revolution. While the latter could be triggered by the former, revolutions could also cause wars, especially civil wars in the course of the events related to a revolutionary process. Due to this insight, Engels remained interested in the military developments and the wars of his time, be it the Crimean War, the US Civil War, or the Franco-Prussian War. ${ }^{69}$ Maybe he was observing these historical events so closely because he hoped that they would unleash another, this time maybe successful, revolutionary process. He would also do so as Engels, like Marx, continued to believe that only a revolution would be able to create a new social order and therefore must have been considered the conditio sine qua non for a better world. ${ }^{70}$

The revolutionary events of $1848 / 49$ consequently forced the two revolutionaries to formulate a concise theory that incorporated the history of revolutions, one that Marx and Engels had witnessed themselves. The failure, therefore, must have had an impact on the understanding of revolutions and the future political course of the proletariat, whose representatives had again not been successful in involving the masses at a level that was perceived as essential for the

$66 M E W_{7}: 440$. For a detailed analysis see Stadler, "Wirtschaftskrise und Revolution, «II3-I44.

67 Neumann and von Hagen, „Engels and Marx on Revolution, 268.

68 Ibid., 269.

69 Ibid., 270.

70 Hunley, Life and Thought of Friedrich Engels, 97. 
success of revolutionary change for the future. They intensified their study of revolutions to come up with a more sophisticated revolution theory, one that would pay tribute to history and the failures of the past. ${ }^{71}$ It was at this time that the terms "locomotives of history « and "dictatorship of the proletariat" first appeared in Marx's and Engels's works, although the two intellectuals never really accurately defined what the latter actually meant. ${ }^{72}$ Their works between I849 and I852 predominantly deal with the question of why the revolution had failed, although capitalist structures were well developed at the time, and why it had been unable to have the impact of the Great French Revolution some decades before, especially in the sense that it did not provide a chance for the communists to drive the revolutionary process any further. ${ }^{73}$ This would, with regard to the further theoretical considerations of Marx and Engels, be one of their main questions: How could the bourgeois-democratic revolution be driven forward to reach the proletarian revolution as some kind of second step in the overall process?74 The historical example of the French Revolution could therefore no longer be used as an ultimate example, although their experience of $1848 / 49$ was often reflected and framed according to their historical knowledge about the events in France between 1789 and $1799 .{ }^{75}$

The events Marx and Engels witnessed during the Revolution of I848 would nevertheless function as a theoretical filter for a reconsideration of the French Revolution. ${ }^{76}$ This means that every revolu-

7I Hundt, "Zur Entwicklung, « 34.

72 Ibid. On the "dictatorship of the proletariat « see Mike Schmeitzner, »Lenin und die Diktatur des Proletariats-Begriff, Konzeption, Ermöglichung, "Totalitarismus und Demokratie I4 (2017): 17-69.

73 Hundt, "Zur Entwicklung, « 35.

74 Ibid., 38.

75 Manfred Kossok, "Karl Marx und die Grundlegung wissenschaftlicher Revolutionsauffassung, "Zeitschrift für Geschichtswissenschaft 28, no. 2 (I980): 99-II8.

76 Lenin would continue to emphasize such an interpretation, when he named the proletarians to be the "Jacobins of the 2oth century. "Wladimir I. Lenin, "Über die Volksfeinde, « in Werke (Berlin: Dietz, 1972), 25: 45. For Marx's view on the French Revolution see: Dan Edelstein, »Revolution in Permanence and the Fall 
tionary theory needs to be updated according to the course of history, which is why the two intellectuals did not understand their own theoretical reflections as something that was written in stone, but rather as something that needed to be adjusted depending on the actual historical course of the future. This is one important aspect that we have to include in our understanding of revolutions as well. They are flexible processes that can hardly be predicted, and there will never be absolute knowledge about the next step within such a process, especially since revolutions are driven forward by human beings, who might not even act or understand themselves as conscious revolutionaries. Revolutions, and this was understood by Marx and Engels, had to be seen within their specific space-time continuum, ${ }^{77}$ and although we can identify some generic developments and possible steps, a revolutionary process can evolve; accordingly, every revolution must be studied in its specific space-time continuum to fully understand its nature, history, and very often its failure as well.

Nevertheless, for Marx and Engels, the working class, i.e. the proletariat, would play the important role within a successful revolution of the future. Hundt identified three constant aspects of Marxist revolution theory that had their origin in the experiences of $1848 / 49$, namely

I. the working class is already an essential part of the bourgeois-democratic revolution,

2. the determination, bravery, and energy of a revolutionary class, on the one hand, and reason and scientific consciousness on the other are decisive elements in times of a revolutionary crisis, and

3. the revolution has to be kept energetic or alive to guarantee success in the end. ${ }^{78}$

of Popular Sovereignty, " in The Scaffolding of Sovereignty: Global and Aesthetic Perspectives on the History of a Concept, eds. Zvi Ben-Dor Benite, Stefanos Geroulanos and Nicole Jerr (New York: Columbia University Press, 2017), $378-384$.

77 Hundt, "Zur Entwicklung, « 46.

78 Ibid., 49 . 
Marx and Engels had, according to these principles, identified four main aspects related to the Revolution of 1848 . These are:

I. the proletariat needs to be self-organized and led by a revolutionary fighting party,

2. the proletariat can only apply its power if it becomes the head and heart of a popular revolution, i. e. leading the masses during the revolutionary process to ultimately achieve a social change as well,

3. the proletariat has to break with and destroy the old political system to establish a classless order, and

4. the revolutionary workers« movement is not only limited by historical materialism and economically determined conditions, but has more than one option for its course of action. ${ }^{79}$

The course of history could consequently only be changed by a revolution if the latter did not act according to non-existent preconditions, which is why each revolutionary process had to deal with specific conditions that could not yet be taken into consideration. This also makes comparative studies of revolutions necessary to really understand the generic aspects that exist and determine revolutionary processes, while differences can highlight specific factors that need to be taken into consideration while reflecting upon a historical revolution. ${ }^{80}$

Regardless of these theoretical reflections, »Marx and Engels persistently repeated the same essential points, independently of circumstance, medium and audience. The conception of a two-stage but uninterrupted revolution belonged to their stable core beliefs, from which they did not back away." ${ }^{81}$ They, however, reformulated their revolution theory and relevant political strategies between I843 and 1850 based on their actual experiences, which means that they attempted to use their own experiences to establish a scientific rev-

79 Ibid., 50-5I.

80 Ibid., 52.

8I van Ree, "Marxism as Permanent Revolution, « 544. 
olution model that would also apply the idea of historical materialism while still being flexible enough to be useful for revolutionaries in different contexts. That implies that they did not have a static model in mind that should be applied for all revolutions. They rather thought of a collection of thoughts that might be used to better understand revolutionary processes as such, including their diversity with regard to time and place. At the same time, as US scholar Dan Edelstein highlighted, "[h] istory itself thus allowed Marx to update the revolutionary theory he and Engels had laid out previously in the Communist Manifesto. In defeat, the proletarians had come out of the shadows of the bourgeoisie and assumed their own identity as a revolutionary class. ${ }^{82}$ In their works of the I840s and I850s, Marx and Engels tried to find the answer to their revolutionary hopes and, during that process, were eager to establish a set of rules or almost natural laws that could be applied to revolutions and taken into consideration by future revolutionaries. ${ }^{83}$ As representatives of "an international community of revolutionary exiles, $"{ }^{84}$ it seemed almost natural that they would pay attention to the events that had caused their exile and the future revolutionary events, which could end it again.

How Engels addressed these pressing questions with regard to revolution, its meaning, its history, and its future shall be taken into closer consideration in the following section, which will provide a close reading of the early writings of the famous German intellectual.

82 Edelstein, »Revolution in Permanence, « 374.

83 Samuel Hollander, "Marx and Engels on Constitutional Reform vs. Revolution: Their >Revisionism^ Reviewed, " Theoria: A Journal of Social and Political Theory 57, no. 122 (2010), Democracy and Exchange: 176.

84 Andrew Zimmerman, "From the Second American Revolution to the First International and Back Again: Marxism, the Popular Front and the American Civil War, in The World the Civil War Made, eds. Gregory P. Downs and Kate Masur (Chapel Hill, NC: University of North Carolina Press, 2015), 304. 


\section{Engels on Revolution}

From early on, it was clear for Engels that a »revolution by legal means - in itself a contradiction, a practical impossibility « ${ }^{85}$ was impossible, because the capitalist elites would not allow a new social order to come into existence in a politically legal way. The early communists, who organized themselves not only in Paris but also in cities of northern Germany, ${ }^{86}$ consequently had to figure out how to reach a better future, which for Engels was not utopian at all ${ }^{87}$ but also not achievable without conflict between the classes, namely between the exploiting and the exploited ones. In a later preface to the 1887 American edition of his famous work The Condition of the Working Class in England (1845), Engels again highlighted the necessity for a revolution when he remarked: "What the Socialists demand, implies a total revolution of the whole system of social production. ${ }^{88}$ That this revolution would be the expression of a class struggle was also highlighted in the I89I preface to the English edition of the work: "So long as the wealthy classes not only do not feel the want of any emancipation, but strenuously oppose the self-emancipation of the working-class, so long the social revolution will have to be prepared and fought out by the working-class alone. ${ }^{89}$ In the famous work itself, Engels described not only the life and precarious situation of the English working class, but also how this modern proletariat had been created by the industrial revolution, which he considered to be

85 Frederick Engels, "The Internal Crises, "Rheinische Zeitung, no. 343 and 344, December 9 and IO, I842. Accessed July 29, 2020. https://marxists.catbull.com/ archive/marx/works/I842/I2/o9.htm.

86 Frederick Engels, "Continental Socialism, « in: Karl Marx and Frederick Engels, Collected Works, vol. 4 (London: Lawrence \&Wishart 20IO), 2I2-2I3.

87 Frederick Engels, "Description of Recently Founded Communist Colonies Still in Existence, « in: Karl Marx and Frederick Engels, Collected Works, vol. 4 (London: Lawrence \&Wishart 2010), 214-228.

88 Friedrich Engels, The Condition of the Working Class in England, London I89I [Leipzig 1845]. Accessed July 29, 2020. https://www.marxists.org/archive/marx/ works/download/pdf/condition-working-class-england.pdf.

89 Ibid. 
"of the same importance for England as the political revolution for France, and the philosophical revolution for Germany. «9०

The sorrows and sufferings of the English workers, however, would, according to Engels, only cease to exist as the consequence of a revolution: "When such insanity prevails in the property-holding class, when it is so blinded by its momentary profit that it no longer has eyes for the most conspicuous signs of the times, surely all hope of a peaceful solution of the social question for England must be abandoned. The only possible solution is a violent revolution, which cannot fail to take place. (9I $^{\text {I }}$ Considering Engels's early work, it is remarkable that he had already identified the relation between capitalist exploitation and the stimulation for a revolution that is created by the exploitative politics of the ruling class. For the young man, who had been involved in the business of the ruling class but also seen the misery it created in towns like Manchester, consequently argued that the continuation of the current exploitative means of capitalism would eventually allow no other choice for the masses but to rise through revolution to change the existent economic, political, and social system. Or, as Engels formulated it,

assuming that England retained the monopoly of manufactures, that its factories perpetually multiply, what must be the result? The commercial crises would continue, and grow more violent, more terrible, with the extension of industry and the multiplication of the proletariat. The proletariat would increase in geometrical proportion, in consequence of the progressive ruin of the lower middle-class and the giant strides with which capital is concentrating itself in the hands of the few; and the proletariat would soon embrace the whole nation, with the exception of a few millionaires. But in this development there comes a stage at which the proletariat perceives how easily the existing power may be overthrown, and then follows a revolution..$^{92}$

90 Ibid.

9I Ibid.

92 Ibid. 
As the English bourgeoisie would not correct the course of history by itself, a revolution seemed inevitable. This also means that the prophecy of revolution was already expressed by Engels in his initial work, although in a specifically English national context. It was consequently obvious that a conflict between the classes needed to find its climax in revolution, which needed to be prepared and led by the working class: "So long as the wealthy classes not only do not feel the want of any emancipation, but strenuously oppose the self-emancipation of the working class, so long the social revolution will have to be prepared and fought out by the working class alone. ${ }^{93}$

In his »Principles of Communism» (»Grundsätze des Kommunismus, « 1847), Engels would continue his reflections on communism and revolution. The former he considered to be the doctrine of the conditions for the liberation of the proletariat, the class that solely gains within the capitalist system by selling its labor: "The proletariat, or the class of proletarians, is, in a word, the working class of the inth century. ${ }^{94}$ In contrast to the slave, the proletarian has to sell his work at a daily or hourly rate and has no secured existence. The proletarian, again in contrast to the slave, is consequently part of capitalist competition and is accepted as a member of society. Consequently, the proletarian has a better legal status than the slave, but is regularly exploited while his life is threatened by this form of capitalist exploitation. While the slave can be liberated when slavery is abolished, the proletarian, however, can only be free when private property as such ceases to exist. ${ }^{95}$

The communists at the same time know, as Engels describes in his answer to question 16, which asks how the abolition of private property can be achieved, that revolutions are not purposely and ar-

93 Ibid.

94 Friedrich Engels, "Grundsätze des Kommunismus (I847), "in Karl Marx and Friedrich Engels, Werke, vol. 4 (Berlin: Dietz, 1974), 36I-380. Accessed June 13, 2020. http://www.mlwerke.de/me/meo4/meo4_36I.htm. English translations taken from: https:/www.marxists.org/archive/marx/works/I847/II/prin-com.htm 95 Ibid. 
bitrarily made, but that they are the result of existent preconditions. ${ }^{96}$ Once the global proletariat is forced into such a revolution by its steady exploitation, it will lead to the end of private property and the capitalist exploitation of the masses. In his answer to question I8, which asks for the course of such a revolution, Engels describes a I2-point agenda for the measures that would have to be taken by the proletariat, once a democratic system had been established. Engels argues that without a proletarian lead and instrumentalization of the revolution, a change of the social order would not be possible. His I2 measures shall therefore be quoted here in some more detail:

I. Limitation of private property through progressive taxation, heavy inheritance taxes, abolition of inheritance through collateral lines (brothers, nephews, etc.) forced loans, etc.

2. Gradual expropriation of landowners, industrialists, railroad magnates and shipowners, partly through competition by state industry, partly directly through compensation in the form of bonds.

3. Confiscation of the possessions of all emigrants and rebels against the majority of the people.

4. Organization of labor or employment of proletarians on publicly owned land, in factories and workshops, with competition among the workers being abolished and with the factory owners, in so far as they still exist, being obliged to pay the same high wages as those paid by the state.

5. An equal obligation on all members of society to work until such time as private property has been completely abolished. Formation of industrial armies, especially for agriculture.

6. Centralization of money and credit in the hands of the state through a national bank with state capital, and the suppression of all private banks and bankers.

7. Increase in the number of national factories, workshops, railroads, ships; bringing new lands into cultivation and improvement of

96 Ibid. 
land already under cultivation - all in proportion to the growth of the capital and labor force at the disposal of the nation.

8. Education of all children, from the moment they can leave their mother's care, in national establishments at national cost. Education and production together.

9. Construction, on public lands, of great palaces as communal dwellings for associated groups of citizens engaged in both industry and agriculture and combining in their way of life the advantages of urban and rural conditions while avoiding the one-sidedness and drawbacks of each.

Io. Destruction of all unhealthy and jerry-built dwellings in urban districts.

II. Equal inheritance rights for children born in and out of wedlock.

I2. Concentration of all means of transportation in the hands of the nation. ${ }^{97}$

Once the first strike against private property has been waged by the proletariat, Engels continues, the latter will be forced to drive the change of the existent economic and social order further and further and "[f]inally, when all capital, all production, all exchange have been brought together in the hands of the nation, private property will disappear of its own accord, money will become superfluous, and production will so expand and man so change that society will be able to slough off whatever of its old economic habits may remain. $^{98}$

With regard to the character of the future revolution as a world revolution, Engels also highlights that the globalization of capitalism will eventually cause a universal and global revolution, one that will probably change the world in our century, as capitalism seems to have reached its maximum extent and is currently facing an extreme global crisis, caused by the COVID-I9 pandemic. Engels, however,

97 Ibid.

98 Ibid. 
although writing in the igth century, had already foreseen that the anti-capitalist revolution would ultimately be a world revolution:

By creating the world market, big industry has already brought all the peoples of the Earth, and especially the civilized peoples, into such close relation with one another that none is independent of what happens to the others. Further, it has co-ordinated the social development of the civilized countries to such an extent that, in all of them, bourgeoisie and proletariat have become the decisive classes, and the struggle between them the great struggle of the day. It follows that the communist revolution will not merely be a national phenomenon but must take place simultaneously in all civilized countries ... It is a universal revolution and will, accordingly, have a universal range.

Engels, in this text, already developed some of the basic considerations of communism that would later also be expressed in the Communist Manifesto (I848) ${ }^{99}$ that, although relatively unimportant during the Revolution of 1848 , would turn into a key document of human history. ${ }^{100}$ Although the text lost some of its appeal after the end of the Cold War, the present crisis stimulated some interest again, especially since more and more young people are looking for alternatives to the capitalist world order. Marx and Engels consequently pointed the navigators of a revolutionary course to the future. ${ }^{\text {Ior }}$

In their key theoretical text, the two intellectuals argued that the history of all past societies must be understood as one of class struggle. ${ }^{102}$ In this struggle, the whole of society is divided according to two main classes, namely the bourgeoisie and the proletariat. ${ }^{103}$ While the

99 On the genesis of the Communist Manifesto see Erbentraut and Lütjen, „Eine Welt zu gewinnen, «79-84. On the importance and impact of this text see Hunley, Life and Thought of Friedrich Engels, 65-79.

Ioo Erbentraut and Lütjen, „Eine Welt zu gewinnen, « 73.

Ior Ibid., 76 .

IO2 Karl Marx and Friedrich Engels, "Manifest der Kommunistischen Partei (I848)," in Karl Marx and Friedrich Engels, Werke, vol. 4 (Berlin: Dietz, 1959), 462.

IO3 Ibid., 463. 
revolutionary class, i. e. the proletariat, holds the power to eventually overcome the existent order and is therefore joined by some enlightened parts of the ruling class, it is the former that is the only truly revolutionary class. ${ }^{104}$ The already existent yet hidden civil war between the classes will eventually turn into an open revolution, which will become the base for the violent end of the bourgeoisie and the establishment of proletarian rule. ${ }^{105}$ The communists are perceived as part of the international workers parties, namely the one that drives the proletariat forward to take their revolutionary chance if the latter should appear in a time of crisis. ${ }^{106}$ The communist revolution will eventually break with the existent conditions of property and capital in the most radical way possible to end the exploitation of one part of society by another. ${ }^{107}$ The revolution would have to make that possible by first establishing a democratic republic that could then be turned into a classless society, and therefore Engels explained in 1892 that "Marx and I, for forty years, repeated ad nauseam that for us the democratic republic is the only political form in which the struggle between the working class and the capitalist class can first be universalized and then culminate in the decisive victory of the proletariat. «108

Regardless of the claims and the attempt to provide a scientific explanation of class struggle and the role of the revolution in overcoming it, the manifesto had, in a way, predicted the revolutionary events of I848, although the outcome was quite different to that which was expected by the two German revolutionaries. ${ }^{109}$ While Marx tried to forge the "people's alliance, the worker-peasant-petit bourgeois coalition to fight for the democratic revolution «"Io through his work for the Neue Rheinische Zeitung, Engels himself was actually involved in

\footnotetext{
IO4 Ibid., 47I-472.

IO5 Ibid., 473 .

Io6 Ibid., 474 .

I07 Ibid., 480-48I.

I08 August H. Nimtz, "Marx and Engels on the Revolutionary Party, Socialist Register 53 (2017), Rethinking Revolution: 249.

I09 Ibid., 250.

IIO Ibid., 25I.
} 
military operations during the revolutionary war, but eventually both men had to accept the facts, namely the failure of the revolutionary movement to gain mass support and to overthrow the existent order. In the end, it seems to have been clear that their predictions were only partly true, which is why both intellectuals continued I) to consider their revolution theory to be a work in progress and 2) to further study historical events in relation to revolutionary processes. Since both of them had to live in exile due to their own roles during the Revolution of $\mathrm{I} 848$, the failure was particularly felt by both intellectuals and their intensified interest to find out about the reasons for the revolution's failure was quite natural.

In I850, Engels published The Peasant War in Germany, ${ }^{\mathrm{III}}$ a work that, to quote US anthropologist Eric R. Wolf, »represents a milestone in social history, and remains a major contribution to debates about the historic role of peasantry today as in the past, «because »it attempted to understand the forces of revolution and counterrevolu-

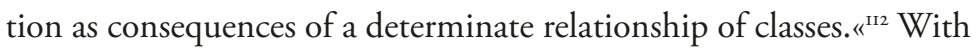
The Peasant War in Germany, Engels tried to provide more than just a reflection about a historical episode of the past. He went way beyond that, and presented a "class analysis of the German countryside« and discussed "the question of historical maturity of the peasantry, the special features of peasant movements, the role of the peasantry in history, and the relationship between revolutionary leaders and the masses. [13 $^{\mathrm{In}} \mathrm{He}$ consequently tries to follow his own suggestions by considering "revolutionary" events of the past in their specific contexts to better understand why they happened or eventually failed. Engels therefore began to analyze different revolutionary case studies to gain further insight for his theoretical understanding of revolutionary processes.

III Friedrich Engels, „Der deutsche Bauernkrieg (I850), « in Karl Marx and Friedrich Engels, Werke, vol. 7 (Berlin: Dietz, 1960), 327-413.

II2 Wolf, "The Peasant War in Germany,« 83-84.

II3 Theodor Bergmann, "Engels on Agriculture, "Science \& Society 62, no. I (1998), Friedrich Engels: A Critical Centenary Appreciation: I47. 
Engels also wanted to emphasize that there was a German revolutionary tradition, although the German states had since I8I5 instead been in support of the counter-revolutionary forces of Europe:

The German people are by no means lacking in revolutionary tradition. There were times when Germany produced characters that could match the best men in the revolutions of other countries; when the German people manifested an endurance and energy which, in a centralized nation, would have brought the most magnificent results; when the German peasants and plebeians were pregnant with ideas and plans which often made their descendants shudder. ${ }^{\text {II }}$

Regardless of this emphasis, the revolutionary events since 1848 had shown that a post-revolutionary unified Germany was not yet a possibility. This problem would also be at the center of Engels's considerations in "Revolution and Counter-Revolution in Germany» (I85I/52). ${ }^{\text {II }}$

The articles that were published by the New York Daily Tribune under Marx's name between 25 October I85I and 23 October 1852 were only identified to have originated in Engels's thought and to have been written by him in 1913, and their first publication in book form had been made possible by Eleanor Marx (I855-1898) in I896. It was written in the aftermath of the Revolution of I848, after which, according to Engels, the "forces of the past " were again the "forces of the present," because the revolutionary parties had suffered from the most severe defeat. ${ }^{116}$ Regardless of the failure to achieve its revolutionary aims, the movement had shown and proved that revolutions are not made by

II4 Engels, "Der deutsche Bauernkrieg (I850), "329. English translation taken from https:/www.marxists.org/archive/marx/works/I850/peasant-war-germany/choI. htm.

II5 Friedrich Engels, »Revolution und Konterrevolution in Deutschland (I85I/52), « in MEW 8: 5-IO8. Accessed June I3, 2020. https://www.marxists.org/deutsch/archiv/ marx-engels/185I/deutsch/index.htm.

II6 Ibid. 
a handful of evil agitators but are an expression of disagreement by the masses and that each revolutionary eruption must be considered the consequence of a social need, whose fulfillment or achievement is prevented by outdated institutions and their representatives. The attempt to prohibit the revolutionary forces from achieving change will, as Engels continued in his analysis, eventually force the masses to break their chains to gain true freedom and liberation as well as a true chance to achieve what they deem necessary with regard to a new and better social order. ${ }^{117}$ The Revolution of I 848 was consequently not caused by individuals, but rather was an eruption of the wish of the masses to create a new, better future. Engels also argues that the role of the petit bourgeoisie, especially in Germany, had been decisive during the revolution, as this class was willing to replace the bourgeoisie but, at the same time, feared falling down to become part of the proletariat as well. What Engels emphasizes here is the diversity of those who might participate in a revolutionary process for different reasons and, for as long as no change has been achieved, build a homogenous mass that directs its anger against the existent establishment, yet will fall apart once the initial aims of the revolutionary process have been achieved. ${ }^{\mathrm{II}}{ }^{\mathrm{I}}$

The famous German intellectual therefore realized and foresaw many problems revolutions would face in the future as well. A successful revolutionary change needed the unity of those who longed for it. For Engels, the Revolution of I 848 failed because the bourgeoisie feared the proletariat more than the counter-revolutionary forces. ${ }^{\text {II } 9}$ In 1895 , when he wrote the introduction to a new edition of Marx's The Class Struggles in France, I848-1850, Engels, from a retrospective, again argued that a new revolution would only be possible as a consequence of a crisis and that all revolutions of the past had been expressions of a continuing class struggle between those who ruled and

\footnotetext{
II7 Ibid.

II8 Ibid.

II Friedrich Engels, „Die Rolle der Gewalt in der Geschichte (I887/8), « in $M E W$ 2I: 408. A similar evaluation could be taken into consideration for the German Revolution of I9I8/19.
} 
those who were exploited. ${ }^{120}$ At the same time, he emphasized that all these revolutions of the past had been minority revolutions, i.e. changes that were led, instrumentalized, and exploited by a leading minority who claimed to lead and rule in the name of a majority. ${ }^{121}$ The radicalization of revolutionary processes was also described as the consequence of the wishes of a majority, whose representatives claimed to follow the original revolutionary ideals, protecting them from, amongst others, the counter-revolutionary forces. The revolutionary masses, on the other hand, lose their energy and will to drive the revolution any further-one could argue this is because the masses tend to be less radical than anticipated-, especially since utopian dreams often turned into bitter disappointment about the promised change. ${ }^{\mathrm{I} 22}$ After I85I, according to Engels, the chance for a revolution from below had ended and what followed were revolutions from above. He also argued that the time in which small groups were able to launch a revolutionary development or process had ended and that a true revolution could only be reached if the masses got actively involved, claiming their only »true historical right, «i. e. »the right for revolution. $\aleph^{123}$

\section{The Afterlife of Engel's Thoughts on Revolution, or: What to Make of Engel's Revolution Theory?}

It was the incompleteness of Marx and Engels's writings with regard to revolution theory that allowed so many to reinterpret them according to current revolutionary processes. They claimed themselves to be acting on behalf of the two eminent revolutionaries and

I20 Friedrich Engels, »Einleitung zu Karl Marx` 'Klassenkämpfe in Frankreich I848 bis I850 (1895), " in $M E W 22: 5 \mathrm{II}$ and $5 \mathrm{I3}$.

I2I Ibid., 513. Reading this text passage one could also argue, that Engels predicted many corruptions of revolutionary processes, e.g. Russia in 1917.

I22 Ibid., 5I4.

I23 Ibid., 523-524. 
theoretical thinkers of the igth century, although they were acting in the realities of the 2oth century. ${ }^{124}$ Of course, Engels, like Marx as well, also considered the French Revolution as an example of when the masses actively sought change, ${ }^{125}$ but was disappointed when they failed to stay active in 1848 . Yet by witnessing the latter events, Engels in particular understood that revolutions would never be fully explained solely by theory. They need the masses to be successful, and the masses tend to react according to their necessities and current demands, not according to a plan, a script, or theoretical assumptions. Therefore, the human factor is probably the most decisive one in every revolutionary process. A successful revolution, and this aspect is supposedly the most important one in Engels's theoretical approach, needed to be a revolution by the majority of the people. ${ }^{126}$ Liana Longinotti highlights this in particular when she writes that

[ $\mathrm{t}$ ] he considerations that are articulated around the theme of the "majority revolution « not only arose in Engels from the lesson of caution derived from the bankruptcy experience of the previous revolutions, but at the same time represented the definitive landing point of a reflection, extended over time, around the ways and forms of the proletarian revolution, which, after starting from the delineation of its successive phases and having passed through the subsumption of the democratic stage within the socialist revolution, came to nuclear its specific and distinctive features with respect to the great bourgeois revolutions. ${ }^{127}$

\footnotetext{
I24 A. James Gregor, Marxism and the Making of China: A Doctrinal History (New York: Palgrave Macmillan, 20I4), 25.

I25 Friedrich Engels, „Die Entwicklung des Sozialismus von der Utopie zur Wissenschaft (1880), « in $M E W_{\text {I9: }}$ 194.

I26 Liana Longinotti, "Friedrich Engels e la 'Rivoluzione di maggioranzaৎ," Studi Storici $\mathrm{I} 5$, no. 4 (1974): 822.

I27 Ibid., 823 .
} 
Engels, who in his later years played an important role in making Marx's work available and advertising its value, ${ }^{128}$ at the same time remained a revolutionary and was almost sad about the neglect of a revolutionary necessity by the German Social Democrats. In a letter to Richard Fischer (1855-1926), he argued: "In the Vorwärts the revolution is sometimes denied with the same effort as it was preached for-maybe sometimes again - in the past. ${ }^{129}$ The Engels of the I89os, in contrast to his more youthful self of the I840s, had witnessed two failed revolutionary attempts, and now wanted to wait until the Social Democratic influence on society was sufficiently strong ${ }^{\mathrm{I3O}}$ and until the military had been sufficiently politicized, especially since he knew that a revolution without the latter's support might be as senseless as it would be hopeless. ${ }^{131}$

In contrast to his later instrumentalization in internal party fights about the revolutionary character of the German Social Democratic Party (SPD), Engels had never given up his belief in and hopes for a successful revolution. ${ }^{\mathrm{I} 2}$ Nevertheless, his edition of Marx's The Class Struggles in France I848-I850 and his introduction for many seemed to anticipate many of Eduard Bernstein's (1850-1932) later claims about peaceful political tactics and the abandonment of the revolution. ${ }^{133}$ Hence, "Engels would have found a parliamentary system gen-

I28 Michael C. Howard and John E. King, A History of Marxian Economics, vol. I: 1883-1929 (Princeton, NJ: Princeton University Press, 1989), 3-20; J. Jemnitz, "Engels and the Problems of the International Labour Movement in the I890s," Acta Historica Academiae Scientiarum Hungaricae 17, no. 3/4 (I97I): 225-255.

I29 Friedrich Engels to Richard Fischer, March 8, I895, cited in Hans-Josef Steinberg, "Revolution und Legalität: Ein unveröffentlichter Brief Friedrich Engels's an Richard Fischer, "International Review of Social History I2, no. 2 (1967): 182.

I30 Ibid., I84.

I3I Ibid., I87.

I32 Ibid., I87-I88. Also see Neumann and von Hagen, „Engels and Marx on Revolution, « 278; Hollander, "Marx and Engels on Constitutional Reform vs. Revolution, « 53 .

I33 Ibid., 5I-52. On Bernstein and his revisionist position see: Manfred B. Steger, The Quest for Evolutionary Socialism: Eduard Bernstein and Social Democracy (Cambridge: Cambridge University Press, 1997). 
erating a working-class majority unwilling to carry out a communist program unacceptable $\ll^{134}$ and was never in favor of abandoning the revolution as the ultima ratio of Social Democratic politics. ${ }^{135}$

Regardless of his wish for a revolutionary change, Engels would also not have been in favor of Lenin's interpretation of his and Marx's work. ${ }^{136}$ From the Russian revolutionary's perspective, as Bertram D. Wolfe (1896-1977), the American communist, scholar, and later anti-communist during the Cold War, remarked,

[i]t was embarrassing to note that Engels had lived on to 1895, and had been brilliantly prophetic in describing the line-up, the magnitude, the nations under arms, the upsurge of national feeling, the socialist desire to avert war (pacifism) and to defend the fatherland (defensism), the possibility that the socialist parties and the International would be temporarily drowned and broken by a flood of chauvinism, the million-massed death toll, the spread of ruin, demoralization and barbarism throughout Europe, in the very war into which Europe had now entered. ${ }^{137}$

After their death, as Engels had complained in a letter to Paul Lafargue (I842-I9II) in I882, his and Marx's works had been turned "into the dogmatism of a scientific oracle ${ }^{138}$ instead of an attempt to understand a revolution in its timely context, something that would become even worse with regard to Soviet Marxism. ${ }^{139}$ Although lat-

I34 Hollander, "Marx and Engels on Constitutional Reform vs. Revolution, " 54 .

I35 Hans-Josef Steinberg, "Freiheit und Notwendigkeit: Aus einem verlorenen Brief von Friedrich Engels an Ernest Belfort Bax vom Jahre 1886, «International Review of Social History I8, no. 2 (1973): 276-280.

I36 Bertram D. Wolfe, "Lenin Has Trouble with Engels, "The Russian Review I5, no. 3 (1956): 197. Also see the more detailed discussion in A. James Gregor, Marxism, Fascism, and Totalitarianism: Chapters in the Intellectual History of Radicalism (Stanford: Stanford University Press, 2009), IO2-I35.

I37 Wolfe, "Lenin Has Trouble with Engels, « 209.

I38 Cited in Schäfer, "Friedrich Engels, « 36.

I39 Herbert Marcuse, "Dialectic and Logic Since the War, in Marxism, Revolution and Utopia (Collected Papers of Herbert Marcuse, vol. 6), eds. Douglas Kellner 
er revolutions would draw inspiration from past events and even attempt to recreate them, ${ }^{\text {I40 }}$ Engels was never in favor of a dogmatic revolution theory, especially not in his own writings, where he instead attempted to describe things to take into consideration for future revolutionary processes. Like Marx, he was affected by the failed European revolutions in $\mathrm{I} 848$ :

Like most of their intellectual contemporaries, they now repudiated utopianism and turned to "science" as the instrument of progress. Their revolutionary goals remained unchanged, as did their belief that labor would one day be transformed from a tool of subjugation to a "means of emancipation, by offering each individual the opportunity to develop all his faculties, physical and mental, in all directions and exercise them to the full, « making work a "pleasure instead of a burden. $\aleph^{141}$

Engels, however, also realized that the masses were often not the most reliable revolutionaries: "we men and women are unfortunately so stupid that we never pluck up courage for real progress unless urged to it by sufferings that seem almost out of proportion. $\aleph^{\mathrm{I} 4^{2}}$ Yet the role of the individuals, like their impact on the revolutionary outcomes,

and Clayton Pierce (London/New York: Routledhge 20I4), 88.

I40 Stephen Eric Bronner, "The Communist Manifesto: Between Past and Present," in Karl Marx and Friedrich Engels, The Communist Manifesto, ed. Jeffrey C. Isaac (New Haven, CT: Yale University Press, 20I2), I45.

I4I Joan Campbell, Joy in Work, German Work: The National Debate, I800-1945 (Princeton, NJ: Princeton University Press, 1989), 23-34. According to Hal Draper and E. Haberkern, "Marx and Engels came to believe that the French had ceded the leadership of the revolutionary movement, at least temporarily, to the Germans. "Hal Draper and E. Haberkern, Karl Marx's Theory of Revolution, vol. 5: War and Revolution (New York: NYU Press, 2005), I30.

I42 Letter by Engels, February 24, I893, in Karl Marx and Friedrich Engels, Correspondence I846-1895 (London: Lawrence \&Wishart, 1934), 510, cited in William A. Pelz, "Class and Gender: Friedrich Engels's Contribution to Revolutionary History, "Science \& Society 62, no. I (1998), Friedrich Engels: A Critical Centenary Appreciation: II7. 
could only be understood in a concrete space-time continuum, and therefore Engels did realize that I848 was not I793, that I87I was not I848, and so on. ${ }^{143}$ Due to this realization, the famous German intellectual also always studied the role of common people: »His contributions to understanding the importance of class are many, but among the most significant are: discerning the importance of the popular masses in history; understanding how common people express themselves within the culture and language of their times; demonstrating how historical consciousness is necessary for radical change; and placing the main emphasis on class struggle, as the motor which moves historical development forward. ${ }^{\mathrm{I} 44}$ Considering the role of individuals and the factors that determined their daily life, Engels, applying Marx's theoretical ideas about historical materialism, also understood that "the final causes of all social changes and political revolutions are to be sought, not in men's brains, not in men's better insight into eternal truth and justice, but in changes in the modes of production and exchange. They are to be sought not in the philosophy, but in the economics of each particular epoch. $\aleph^{145}$ All in all, for Engels,

Marxist revolution required circumstances that made available a society in which the "vast majority« of the population had been rendered "proletarian, « in the process of which commodity production had fully matured, generating the material wherewithal to fully liberate

I43 Ibid., II8.

I44 Ibid., I2I.

I45 E. N. Trubetskoi, "Toward Characterization of the Theory of Marx and Engels on the Significance of Ideas in History, "in Problems of Idealism, ed. Edward A. Purcell (New Haven, CT: Yale University Press, 2003), I27. Trubetskoi criticizes Engels's view for being too narrowly focused on historical materialism here: "In this whole theory there is a large share of truth. It is impossible to deny that economic facts play a primary role in social revolutions, or that people are generally inclined to sympathize with precisely the legal and political princi-ples that most correspond to their interests. It is another question whether only economic interests should be treated as independent causes of social revolutions, whether they alone determine the legal and political ideals of people." Ibid., I39. Also see ibid., 274 . 
humanity from the curse of poverty and compulsory labor. Among some of the very last things he was to write, Engels reminded revolutionaries once again that the only truly Marxist revolution was one undertaken by a population that was essentially urban and proletarian, that would seize the "gigantic productive forces" provided by mature machine capitalism, so that they might be marshaled to "planned production. $\aleph^{146}$

So what are we supposed to make of Engels's revolution theory, or is there anything we can make of it at all? While it does not make sense for revolutionaries to identify themselves with the past, ${ }^{\mathrm{I}}{ }^{\mathrm{I}}$ it does make sense to take a minute to look back at Engels's writings. They offer us a lot of thoughts about revolutions and provide hope for their success, while at the same time do not neglect the dangers of every revolutionary process. Engels's writings about revolutions were an incomplete theoretical framework, yet were enough to engage future generations to think about the possibilities, necessities, and problems revolutions can cause. Therefore, his writings about revolution are even more important today. Not because we should be too inspired by 1848 or any other revolution of the past, but rather to sharpen our mind for possible revolutions in the future. Crises are a necessary precondition, the role of the masses is essential, and what role will the military play? Such considerations, willingly or unwillingly, must lead back to the revolution theory of Friedrich Engels, and it could be argued that those who wish to see a successful revolution of a majority would be wise to read his works in advance. If they can avoid the failure of a future revolution, that is maybe only pure chance, but at least they would be prepared for the possible turns of any revolutionary process. Considering the importance of such a legacy, it is tragic that the revolutionary Engels never experienced a successful revolution.

I46 Gregor, Marxism and the Making of China, 26. Engels's citations are taken from Engels, "Nachwort (I894) [zu 'Soziales aus Russland ], "MEW 22: 426-428.

I47 Eric Hobsbawm, "Revolution, " in Revolution in History, eds. Roy Porter and Mikuláš Teich (Cambridge/New York : Cambridge University Press, 1986), 9. 
After 200 years, it is time to prove his ideas about revolutions and to use them effectively to provide true freedom for all.

\section{Works Cited}

Andrew, Christopher. Secret World: A History of Intelligence. New Haven, CT: Yale University Press, 2018.

Berger, Martin. "Disentangling Engels from Marxandengels." International Labor and Working-Class History I2 (1977): 4I-44.

—. "Engel's Theory of the Vanishing Army: A Key to the Development of Marxist Revolutionary Tactics." The Historian 37, no. 3 (1975): 42I-435.

Bergmann, Theodor. "Engels on Agriculture." Science d Society 62, no. I (1998), Friedrich Engels: A Critical Centenary Appreciation: I45-162.

Bleuel, Hans Peter. Friedrich Engels: Bürger und Revolutionär. Bern/Munich: Scherz, 198I.

Bronner, Stephen Eric. »The Communist Manifesto: Between Past and Present." In Karl Marx and Friedrich Engels, The Communist Manifesto, ed. Jeffrey C. Isaac, I44-165. New Haven, CT: Yale University Press, 2012.

Campbell, Joan. Joy in Work, German Work: The National Debate, I800-1945. Princeton, NJ: Princeton University Press, 1989.

Claeys, Gregory. "The Political Ideas of the Young Engels, I842-1845: Owenism, Chartism, and the Question of Violent Revolution in the Transition from ,Utopian to 'Scientific Socialism." History of Political Thought 6, no. 3 (1985): 455-478.

Concheiro, Elvira. »A Century after His Death: Friedrich Engels and the Concept of Political Parties."Science \& Society 62, no. I (1998), Friedrich Engels: A Critical Centenary Appreciation: 163-180.

Davis, Horace B. "Nations, Colonies and Social Classes: The Position of Marx and Engels."Science \& Society 29, no. I (1965): 26-43.

Draper, Hal and E. Haberkern, Karl Marx's Theory of Revolution, vol. 5: War and Revolution. New York: NYU Press, 2005.

Edelstein, Dan. "Revolution in Permanence and the Fall of Popular Sovereignty." In The Scaffolding of Sovereignty: Global and Aesthetic Perspectives on the History of a Concept, eds. Zvi Ben-Dor Benite, Stefanos Geroulanos and Nicole Jerr, 371-392. New York: Columbia University Press, 2017. 
Eichhorn, Wolfgang. "Gesetzmäßigkeit von Revolutionen.« Sitzungsberichte der Akademie der Wissenschaften der DDR. Gesellschaftswissenschaften II (1984).

Engelberg, Ernst and Wolfgang Küttler, eds. Formationstheorie und Geschichte: Studien zur historischen Untersuchung von Gesellschaftsformationen Werk von Marx, Engels und Lenin. Berlin: Akademie-Verlagm 1978.

Engels, Friedrich. „Continental Socialism.«In: Karl Marx and Frederick Engels, Collected Works, vol. 4, 2I2-213. London: Lawrence \& Wishart 2010.

-. "Der deutsche Bauernkrieg (I850)." In Karl Marx and Friedrich Engels, Werke, vol. 7, 327-413. Berlin: Dietz, 1960.

-. "Description of Recently Founded Communist Colonies Still in Existence." In: Karl Marx and Frederick Engels, Collected Works, vol. 4, 2I4-228. London: Lawrence \& Wishart 2010.

-. "Die Entwicklung des Sozialismus von der Utopie zur Wissenschaft (I880)." In Karl Marx and Friedrich Engels, Werke, vol. I9, I89-20I. Berlin: Dietz, 1962.

—. "Die Rolle der Gewalt in der Geschichte (1887/8). «In Karl Marx and Friedrich Engels, Werke, vol. 2I, 405-46r. Berlin: Dietz, 1962.

—. "Einleitung zu Karl Marx ‘ Klassenkämpfe in Frankreich 1848 bis I850 (1895).«In Karl Marx and Friedrich Engels, Werke, vol. 22, 509-527. Berlin: Dietz, 1963.

—. Herr Eugen Dühring's Revolution in Science (Anti-Dühring). New York: International Publishers, I939.

—. "Grundsätze des Kommunismus (1847)." In Karl Marx and Friedrich Engels, Werke, vol. 4, 36I-380. Berlin: Dietz, I974. Accessed June I3, 2020. http://www.mlwerke.de/me/meo4/meo4_36r.htm.

-. "Revolution und Konterrevolution in Deutschland (185I/52)." In Karl Marx and Friedrich Engels, Werke, vol. 8, 5-108. Berlin: Dietz, 1988. Accessed June I3, 2020. https://www.marxists.org/deutsch/archiv/marx-engels/1851/deutsch/index.htm.

-. The Condition of the Working Class in England, London I89I [Leipzig I845]. Accessed July 29, 2020. https://www.marxists.org/archive/marx/works/ download/pdf/condition-working-class-england.pdf.

-. "The Internal Crises." Rheinische Zeitung, no. 343 and 344, December 9 and IO, I842. Accessed July 29, 2020. https://marxists.catbull.com/archive/marx/works/1842/ı2/o9.htm. 
Erbentraut, Philip and Torben Lütjen. „Eine Welt zu gewinnen: Entstehungskontext, Wirkungsweise undNarrationsstruktur des ,Kommunistischen Manifestsı."In Manifeste: Geschichte und Gegenwart des politischen Appells, eds. Johanna Klatt and Robert Lorenz, 73-98. Bielefeld: Transcript Verlag, 20IO.

Fetscher, Iring. "Friedrich Engels, Polen und der Russische Imperialismus." Osteuropa 7, no. 6 (1957): 43I-432.

Gregor, A. James. Marxism and the Making of China: A Doctrinal History. New York: Palgrave Macmillan, 2014.

-. Marxism, Fascism, and Totalitarianism: Chapters in the Intellectual History of Radicalism. Stanford: Stanford University Press, 2009.

Hammen, Oscar J. "Alienation, Communism, and Revolution in the Marx-Engels Briefwechsel." Journal of the History of Ideas 33, no. I (1972): 77-100.

Henderson, William O. The Life of Friedrich Engels, 2 vols. London: Frank Cass, 1976.

Hobsbawm, Eric. "Revolution."In Revolution in History, eds. Roy Porter and Mikuláš Teich, 5-46. Cambridge/New York : Cambridge University Press, 1986.

Hollander, Samuel. Friedrich Engels and Marxian Political Economy. Cambridge: Cambridge University Press, 20II.

—. "Marx and Engels on Constitutional Reform vs. Revolution: Their, Revisionism» Reviewed." Theoria: A Journal of Social and Political Theory 57 , no. 122 (2010), Democracy and Exchange: 5I-9I.

Howard, Michael C. and John E. King. A History of Marxian Economics, vol. I: $1883-1929$. Princeton, NJ: Princeton University Press, 1989.

Hundt, Martin. "Zur Entwicklung der marxistischen Revolutionstheorie nach der Revolution von I848/49." Marx-Engels-Jahrbuch Io (1986): 3I-64.

Hunley, J. D. Life and Thought of Friedrich Engels: A Reinterpretation of His Life and Thought. New Haven, CT: Yale University Press, I991.

Hunt, Tristram. Friedrich Engels: Der Mann, der den Marxismus erfand, transl. by Klaus-Dieter Schmidt, third edition. Berlin: List, 2020.

Ito, Narihiko. "Realismus und Utopismus." In Zwischen Utopie und Kritik: Friedrich Engels - ein "Klassiker « nach Ioo Jahren, eds. Theodor Bergmann, Mario Keßler, Joost Kircz and Gert Schäfer, 23-33. Hamburg: VSA, 1996. Jacob, Frank. I917: Die korrumpierte Revolution. Marburg: Büchner, 2020. 
Jemnitz, J. "Engels and the Problems of the International Labour Movement in the 1890s." Acta Historica Academiae Scientiarum Hungaricae 17, no. 3/4 (1971): 225-255.

Joseph, Jonathan. Social Theory: Conflict, Cohesion and Consent. Edinburgh: Edinburgh University Press, 2003.

Kitchen, Martin. "Friedrich Engels's Theory of War."Military Affairs 4I, no. 3 (1977): II9-I24.

Kossok, Manfred. "Karl Marx und die Grundlegung wissenschaftlicher Revolutionsauffassung." Zeitschrift für Geschichtswissenschaft 28, no. 2 (1980): 99-II8.

—. "Revolution und Weltgeschichte im Werk von Walter Markov.» In Walter Markov, Weltgeschichte im Revolutionsquadrat, ed. and introduced by Manfred Kossok, vii-xv. Berlin: Akademie-Verlag, 1982.

—, ed. Studien über die Revolution. Berlin: Akademie-Verlag, 1969.

- and Walter Markov, eds. Studien zur vergleichenden Revolutionsgeschichte I500-19I7. Berlin: Akademie-Verlag, 1974.

Krieger, Leonard. "Marx and Engels as Historians. "Journal of the History of Ideas I4, no. 3 (1953): 38I-403.

Labica, Georges. "Engels and Marxist Philosophy.» Science \& Society 62, no. I (1998), Friedrich Engels: A Critical Centenary Appreciation: 13-34.

Lenin, Wladimir I. "Über die Volksfeinde.«In Werke, vol. 25, 45-46. Berlin: Dietz, 1972.

Leopold, David. »The Structure of Marx and Engels's Considered Account of Utopian Socialism." History of Political Thought 26, no. 3 (2005): 443-466.

Levine, Norman. The Tragic Deception: Marx contra Engels. Santa Barbara/Oxford, Clio Books, 1975 .

Longinotti, Liana. "Friedrich Engels e la ’Rivoluzione di maggioranza «" Studi Storici 15 , no. 4 (1974): 769-827.

Löwy, Michael. "Friedrich Engels on Religion and Class Struggle."Science \& Society 62, no. I (1998), Friedrich Engels: A Critical Centenary Appreciation: $79-87$.

Lucas, Erhard. "Marx und Engels's Auseinandersetzung mit Darwin: Zur Differenz zwischen Marx und Engels. "International Review of Social History 9, no. 3 (1964): 433-469.

Marcuse, Herbert. "Dialectic and Logic Since the War." In Marxism, Revolution and Utopia (Collected Papers of Herbert Marcuse, vol. 6), eds. 
Douglas Kellner and Clayton Pierce, 82-93. London/New York: Routledge 20I4.

Marx, Karl and Friedrich Engels. "Manifest der Kommunistischen Partei (I848)."In Karl Marx and Friedrich Engels, Werke, vol. 4, 459-493. Berlin: Dietz, I959.

- The Eighteenth Brumaire of Louis Bonaparte (1852). Accessed August 20, 2020. https://www.marxists.org/archive/marx/works/1852/18thbrumaire/.

— and Friedrich Engels. The German Ideology. Moscow: Progress Publishers, 1976.

Moss, Bernard H. "Marx and Engels on French Social Democracy: Historians or Revolutionaries?" Journal of the History of Ideas 46, no. 4 (1985): 539-557.

Murphy, John, ed. Socialism and Communism. New York: Britannica Educational Publishing, 20I5.

Neumann, Sigmund and Mark von Hagen. "Engels and Marx on Revolution, War, and the Army in Society."In Makers of Modern Strategy from Machiavelli to the Nuclear Age, ed. Peter Paret, 262-28o. Princeton, NJ: Princeton University Press, 1986.

Nimtz, August H. "Marx and Engels on the Revolutionary Party.« Socialist Register 53 (2017), Rethinking Revolution: 247-264.

Oncken, Hermann. »Friedrich Engels und die Anfänge des deutschen Kommunismus." Historische Zeitschrift I23, no. 2 (I92I): 239-266.

Pelz, William A. „Class and Gender: Friedrich Engels's Contribution to Revolutionary History."Science \& Society 62, no. I (1998), Friedrich Engels: A Critical Centenary Appreciation: 117-I26.

Schäfer, Gert. „Friedrich Engels: Builder of Closed Systems?» Science \& Society 62, no. I (1998), Friedrich Engels: A Critical Centenary Appreciation: $35-47$.

Schmeitzner, Mike. "Lenin und die Diktatur des Proletariats - Begriff, Konzeption, Ermöglichung." Totalitarismus und Demokratie I4 (2017): 17-69.

Silberner, Edmund. The Problem of War in Nineteenth Century Economic Thought. Princeton, NJ: Princeton University Press, 1946.

Singh, Rustam. "Status of Violence in Marx's Theory of Revolution." Economic and Political Weekly 24, no. 4 (1989): 9-20. 
Stadler, Peter. »Wirtschaftskrise und Revolution bei Marx und Engels: Zur Entwicklung ihres Denkens inden I85oer Jahren, "Historische Zeitschrift I99, no. I (I964): II3-I44. 52X

Steger, Manfred B. The Quest for Evolutionary Socialism: Eduard Bernstein and Social Democracy. Cambridge: Cambridge University Press, 1997.

Steinberg, Hans-Josef. „Freiheit und Notwendigkeit: Aus einem verlorenen Brief von Friedrich Engels an Ernest Belfort Bax vom Jahre i886."International Review of Social History 18, no. 2 (1973): 276-280.

Hans-Josef Steinberg, "Revolution und Legalität: Ein unveröffentlichter Brief Friedrich Engels's an Richard Fischer, International Review of Social History I2, no. 2 (1967): 177-189. 54X

Trubetskoi, E. N. »Toward Characterization of the Theory of Marx and Engels on the Significance of Ideas in History. "In Problems of Idealism, ed. Edward A. Purcell, I24-I42. New Haven, CT: Yale University Press, 2003.

Ree, Erik van. "Marxism as Permanent Revolution." History of Political Thought 34, no. 3 (2013): 540-563.

Wallach, Jehuda L. Die Kriegslehre von Friedrich Engels. Frankfurt am Main: Europäische Verlagsanstalt, 1968.

Wittfogel, Karl A. »The Marxist View of Russian Society and Revolution." World Politics I2, no. 4 (I960): 487-508.

Wolf, Eric R. "The Peasant War in Germany: Friedrich Engels as Social Historian."Science \& Society 5I, no. I (1987): 82-92.

Wolfe, Bertram D. "Lenin Has Trouble with Engels. "The Russian Review I5, no. 3 (1956): 196-209.

Zimmerman, Andrew. "From the Second American Revolution to the First International and Back Again: Marxism, the Popular Front and the American Civil War." In The World the Civil War Made, eds. Gregory P. Downs and Kate Masur, 304-336. Chapel Hill, NC: University of North Carolina Press, 2015.

Zirke, Gerhard. Der General: Friedrich Engels, der erste Militârtheoretiker der Arbeiterklasse. Leipzig: Urania-Verlag, 1967. 


\title{
The Gens, Military Conquest, and the Formation of the Manchu State
}

\author{
Understanding the Pre-State Manchu Society \\ from an Engelsian Perspective (1550-1651)
}

Jia Feng

Introduction

In The Origin of the Family, Private Property, and the State (1884), Friedrich Engels portrays a progressive picture of how human society evolved from a simple gentile order to the state in correspondence with the development of social production and the changed forms of property distribution, more specifically from common to private ownerships. To illustrate this fundamental transformation, much ink has been spilled on the institutions of society organized in peacetimes based on and in wartimes mobilized by gens, which Engels defines as "the foundation of the social order of most, if not all, the barbarian peoples of the world. $\aleph^{\mathrm{I}}$ In a gens, all members shared equal tribal and gentile rights, such as equal share of common property, equal voice in democratic assembly, and shared obligations to revenge and defense. ${ }^{2}$ Several gentes constitute a phratry (brotherhood), and several phratries constitute a tribe. ${ }^{3}$ Facing common enemies might bring different gens into a temporary confederation, but most of them dissolved right upon the fading of threats. ${ }^{4}$ As Engels argues, the gentile system was simply a "natural grouping, " suited perfectly to sparse popula-

I Friedrich Engels, The Origin of the Family, Private Property, and the State (Chippendale, Australia: Resistance Books, 2004), 53.

2 Ibid., 88-92.

3 Ibid., 92-93.

4 Ibid., 95. 
tions over a vast territory. 5 Although war captives were indeed admitted into the conqueror's tribe, because of the extremely undeveloped level of social production, where human labor "yielded no noticeable surplus as yet over the cost of its maintenance, " war prisoners were killed. Even for the tribes that indeed adopted the defeated as equal members, "the tribe remained the boundary for man, in relation to himself as well as to outsiders. ${ }^{6}$

As Engels argues, arising from the development of social production, intertribal wars not only broke loose the gentile institutions based on personal ties of blood but also facilitated the rise of public power, the institutionalization of which was the state. In other words, the state emerged inevitably at the price of the dissolution of the old gentile order. Engels suggests that the rise of patriarchal authority and the inheritance of property by children was at the root of incentives of the supreme tribal leaders to extend their territories by waging wars. ${ }^{7}$ The development of private property also rendered it necessary to create hereditary system by replacing elective offices and, due to the corresponding demand for surplus human labor, to expand the enslavement of war prisoners to fellow members of the tribe. Personal wealth is thus "respected as the highest treasure, and the old gentile institutions are perverted in order to justify forcible robbery of wealth. ${ }^{8}$

Incorporating more people set in motion the growth of institutions serving public purposes, more specifically the increasing centralized royal power. The institutions that facilitated royal power included the rise of the retinue. The quickly expanding population could not be governed anymore "by means of the old gentile constitution. « The king's permanent retinue or royal hereditary offices took its place. ${ }^{9}$ Public power existed in various forms, including the

\footnotetext{
$5 \quad$ Ibid., I 48.

6 Ibid., 65, 99 .

7 Ibid., I06.

8 Ibid., I07.

9 Ibid., I43.
} 
police force, army, and administrative officers. ${ }^{\text {10 }} \mathrm{New}$ rules also arose that institutionalized the unequal distribution of booty and the concentration of wealth in the hands of the military commander and subcommanders or rising nobility. ${ }^{\text {II }}$

Especially illuminating is Engels's insight on the lasting influence of the old gentile mentality when gentile organizations dissolved in many places in the face of the growing state machine. ${ }^{12}$ When commenting on why, in the 5th century, the invading Germans could transform the declining Roman empire that had a far greater level of civilization than the invaders themselves, Engels writes,

What was the mysterious charm with which the Germans infused new vitality into dying Europe? Was it the innate magic power of the German race, as our jingo historians would have it? By no means. Of course, the Germans were a highly gifted Aryan tribe, especially at that time, in full process of vigorous development. It was not their specific national qualities that rejuvenated Europe, however, but simply-their barbarism, their gentile constitution. ${ }^{13}$

The "gentile mentality" also entailed "personal efficiency and bravery," which was widely seen in nomadic groups, and the sense of cohesion settling in gentes. ${ }^{14}$ In other words, when "conquered and conquerors were almost at the same stage of economic development and the economic basis of society remained the same as before ... the gentile constitution could continue for many centuries in a changed, territorial form. $\ll^{15}$

The founders of the Qing dynasty (I644-19II), the last dynasty in Chinese imperial history, were ethnically Manchus, who originated in

\footnotetext{
IO Ibid., II5, 136 .

II Ibid., I36, I43.

I2 Ibid., II5.

I3 Ibid., I45-I46.

I4 Ibid., I46.

I5 Ibid., I57.
} 
Manchuria, part of the northeastern provinces of today's China. ${ }^{16}$ The name "Manchus" was not officially adopted until I636, before which later Manchu conquerors were called »Jurchens" by the Ming people due to their shared ethnic origins with the Jin dynasty (III5-I234) founders. ${ }^{17}$ At the turn of the 15 th century, there were three major Jurchen sub-groups: the Jianzhou, the Haixi, and the Yeren, so-called because of their varying degrees of economic development. ${ }^{18}$ In the late i6th century, the Jianzhou branch rose to dominance by annexing the other Jurchen tribes, and within decades went on to conquer the Ming court (1368-1644).

In this paper, I will demonstrate that The Origin of the Family, Private Property, and the State offers certain important insights to our understanding of the transition of late 16 th-and early i7th-century Manchu tribal society into a state. For example, Engels makes it clear that the gens is an institution "common to all barbarians up to their entry into civilization. (19 $^{19}$ Pre-conquest Manchu society, as I will point out below, despite its regular economic exchanges with the then reigning Ming court (1368-I644), was tribal in nature, organized by different equivalents of gens, phratries, and tribes. Hunting organizations were also based on gentes, first as the niru (company), the basic hunting and later military unit under which Jurchen men were organized, and then the gusa, larger divisions consisting of several niru, or banners. These were the foundational organizations of the Eight Banners System, the Manchus' trademark system, which recent revisionist Qing historiography claims to be the institutional bulwark of Manchu senses of in-groupness

I6 Franz Michael, The Origin of Manchu Rule in China: Frontier and Bureaucracy as Interacting Forces in the Chinese Empire (New York: Octagon Books, 1965), I2.

I7 Liu Xiaomeng, Manzu cong buluo dao guojia de fazhan (Beijing: Zhongguo shehui kexue chubanshe, 2007), I.

I8 Pei Huang, Reorienting the Manchus: A Study of Sinicization, I583-I795 (Ithaca, NY: Cornell University Press, 20II), IOI.

I) Engels, Origin, 88. 
or Manchu ethnic identity and to play a crucial role in making and maintaining Qing rule. ${ }^{20}$

The fact that pre-conquest Manchu society was fundamentally tribal and no exception to what Engels says about pre-state social organizations carries important theoretical weight because this fact poses a question on the special nature of the "Manchu way, " a package of time-honored Manchu customs, especially warrior values and martial culture dating back to the Manchu tribal and hunting age, the upholding of which is designated by recent Qing historiography as crucial to the strengthening and maintaining of the dynasty's rule. Moreover, in its narration of the earliest period of Qing history, this scholarship tends to see the tribal-era development of banners, hunting units by origin, not only as a uniquely Manchu innovation but also as offering incentives to enhanced Manchu ethnic solidary, a key element to the transformation of Manchu tribes into the state. ${ }^{21}$ Drawing upon insights from Engels's The Origin of the Family, Private Property, and the State, I will not only argue that the banners, essentially military units organized according to Manchu gentes, were not exceptions to any other early society before their entry into or contact with civilization, but also that this ethnic-centered view falls short in explaining the socio-economic and correspondingly political process of Manchu state-building.

20 Mark Elliott, The Manchu Way: The Eight Banners and Ethnic Identity in Late Imperial China (Stanford: Stanford University Press, 200I). Recent revisionist Qing historiography argues that the Manchu ethnic identity persisted throughout the dynasty and that the Manchu ruling class conscious efforts to institutionalize the differences between the conquerors and the conquered not only enhanced the cohesion among the conquest elites but also strengthened the ties with culturally adjacent Inner Asian minority groups. See Pamela Crossley, A Translucent Mirror: History and Identity in Qing Imperial Ideology (Berkeley: University of California Press, 1999); Evelyn S. Rawski, The Last Emperors: A Social History of Qing Imperial Institutions (Berkeley: University of California Press, 1998). For a review of the New Qing history scholarship, see Joanna Waley-Cohen, »The New Qing History, "Radical History Review 88 (2004): 193-206.

2I Elliott, The Manchu Way, 8-I3. 
My argument in this paper consists of two distinct but interrelated parts. First, I will argue that the Manchus` persistent consciousness to maintain their identities as a distinct ethnic group, and in particular such virtues as the toughness and virility suited to hunting and tribal life, in fact evinces the lasting legacy of Manchu "gentile mentality" in Engels's discussion of the role of barbarism in rejuvenating the conquered but more civilized societies. This mechanism by which gentile institutions continued to exist for a long time in changed forms, however, is not a unique quality of Manchus, but common to "the most diverse savage and barbarian peoples of the present day. ${ }^{22}$

The second part of my argument is related to the first, in the sense that to fully comprehend the Manchu state-building process in the late I6th and early 17 th centuries, it is critical to recognize the tribal and gentile origins of the Eight Banners System and to analyze the making of the Qing state not as enhancing those tribal elements, but as an opposite process of undermining, in part at least, the Manchu gentile constitution. More specifically, I will argue that the Manchu state arose precisely at the price of dissolving the economic principle of the "eight privileges, " namely the equal distribution of booty, people, and lands among eight great families, the latter of which derived from Manchu time-honored customs and economically buttressed the Eight Banners System. I will demonstrate that the rapidly expanding territories and substantially increased number of people brought under the control of the regime created new institutional options for the throne's incumbent to enhance his power through mobilizing new tax resources and establishing new administrative organizations and allowed him opportunities to maneuver the gentile principles of equality among tribal members in a despotic direction. The economic principle that conditioned the Eight Banners System became increasingly contradictory with the development of political centralization; the consolidation of royal power precisely resulted from the defeating of the dominance of old gentile Manchu rules. In short, it was pre- 
cisely in the place where the dominance of the gentile constitution of the Manchu conquest regime dissolved that the Qing state arose.

Despite taking Engels's insights on gentile institutions of early human society seriously, however, I do not mean to say that all prestate societies were the same, nor do I deny the unique characteristics, trajectories, and dynamics of the Manchu state-building process. In fact, because Engels's theoretical framework is based on empirical evidence primarily from Europe and occasionally from America, much more work could be done from the perspective of non-Western histories to form a more balanced account of the transition from tribal society to the state. More specifically, I will delineate in detail the changing land and population policies of the Manchu conquest regime and, in particular, how the increased number of people brought under the conqueror's control turned the Manchu state formation in a centralized direction. While this study will reveal the not too special socio-economic origin of the "Manchu Way, « it will also take on Engels's insights on the almost universal transition of early human society from gens to state to argue that the Manchu state arose not from the maintaining of gentile principles, but at the cost of them. Thus, Engels's analysis of the breakdowns of the gens as an inevitable part of the emergence of state sheds new light on the socio-economic elements of Manchu state-building in the early I7th century and the nature of the "Manchu Way.»

\section{The Manchu Gentile Society Before Conquest}

Before conquest, the Jurchen society was organized in tribes, with the hala (clan, family) as the basic tribal unit followed by the mukun (clan, extended family), a social organization that grew out of and increasingly replaced the hala as a more elemental unit to organize people due to population growth, migration, and intertribal wars.

In early Jurchen history, the hala was the very earliest social form and thus the first social identity, which had a continued legacy across 
generations. The word hala was among the oldest Manchu words. ${ }^{23}$ Sharing the same hala usually indicated sharing the same geographical and ancestral origin. ${ }^{24}$ Jurchen society of the hala stage also shared marriage and other social organizing principles with other barbarians. For example, Manchu ethnogenesis records often show a marriage of a male to a female from a different hala, which indicates the prohibition of marriage within the same tribal group. ${ }^{25}$ Other early Manchu records also demonstrate the practices of adopting individual members of a gens who had been either hit by a natural disaster or on the losing side of an intertribal war into another. ${ }^{26}$

As Jurchen society grew both in size and complexity, the new social organization of the mukun emerged to replace the hala as the most basic clan unit. A distinct feature of the mukun was that, unlike the hala, being members of the same mukun did not necessarily mean either the same ancestry or the same surname. Instead, while people in the same mukun might have different ancestral origins, people sharing the same ancestry might have different surnames. ${ }^{27}$ By the mid-I6th century, due to the high frequency of migration as a result of wars, trades, and some sort of tribal annexation, the mukun had replaced the hala in some more advanced societies such as Jianzhou and Haixi Jurchens. ${ }^{28}$ In short, while the difference between the hala and mukun was not always so clear, generally speaking, the hala was larger than the mukun. As Aisin Gioro, the surname of the Qing ruler, demonstrated, within the Gioro hala, there were many other mukun than Aisin itself, such as Yi'ergen, Hulun, Tongyan, etc. ${ }^{29}$

23 Liu, Manzu cong buluo dao guojia de fazhan, I8.

24 Liu Xiaomeng, Manzu de shehui yu shenghuo (Beijing: Beijing tushuguan chubanshe, 1998), i8.

25 Manzhou shilu, vol. I (Taibei: Huawen chubanshe, 1964), 4-5.

26 Liu, Manzu cong buluo dao guojia de fazhan, 2 I.

27 Liu, Manzu de shehui yu shenghuo, I4.

28 Ortai et al., eds., Baqi manzhou shizu tongpu, vol. I2 (Shenyang: Liaohai chubanshe, 2002 [1744]), I2.

29 Mo Dongyin, Manzushi luncong (Beijing: Renmin chubanshe, I958), 23. 
As a nomadic group, hunting was the central aspect of Jurchen economic life. In early Jurchen society, the uksun was the basic hunting unit..$^{30}$ The very activity of hunting required each band to maintain a moderate size for quicker mobility, making the uksun a more desirable form than the mukun. Hunting spoils were equally distributed between tribal members, a fact that complies perfectly with what Engels says about barbarians up to their entry into civilization who lived in gens governed by the principles of democracy and equality between individuals. ${ }^{31}$ In the Manchu language, each share was called a $u b u$. Originally denoting the equal distribution of hunting spoils, the $u b u$ later became the unit of the equal distribution of booty, captives, lands, and power. ${ }^{32}$

Within each uksun, more direct blood ties were maintained in a boo, or a family. The Jurchen hunting and gathering economy set an upper limit on the size of a family; while the eldest sons moved out upon adulthood to establish their own independent families, the youngest stayed to inherit the family fortune. ${ }^{33}$

Hunting activities were generally organized based on the family-clan organization. Jurchen hunters made their hunting tours in companies based on the unit of the gasan. In each tour, every hunter was allowed to shoot one arrow. The basic hunting unit was decimally organized, and was composed of a headman (ejen) and nine hunters. ${ }^{34}$ The ejen was chosen based on his recognized hunting experience. ${ }^{35}$

Social organizations that arose from hunting practices prompted the forging of early quasi-military institutions. In daily and smallscale hunting activities, Jurchen hunters marched in groups, encircled a large swath of forest from all directions, gradually tightened the

30 Liu, Manzu de shehui yu shenghuo, 29.

3I Engels, Origin, 88, 90.

32 Chen Wenshi, "Qingtaizong shidai de zhongyao zhengzhi cuoshi, " in Chen Wenshi, Mingqing zhengzhi shehui shilun, vol. 2 (Taibei: Taiwan xuesheng shuju, I99I), 423-525.

33 Liu, Manzu cong buluo dao guojia de fazhan, 47.

34 Taizu shilu, vol. 3 (Taibei: Huawen chubanshe, I964), 6.

35 Zhao-lian, Xiaoting zalu (Beijing: Zhonghuashuju, 2017 [I8I4-I826]), 220. 
circle, and finally drove animals within into a clearing to be shot. ${ }^{36}$ A larger-scale hunting activity, known in Manchu as $a b a$, contained a couple of decimal units. Before marching into the targeted forest, hunters gathered in arrays, distinguished by the colors of their banners. In a broader view, the banners were spread like a tree diagram, with the yellow banner placed at the center bottom, two shoulder banners colored red and white down to the left and right, and two head banners of blue placed further below each of the shoulder banners. ${ }^{37}$ The Manchu word niru means a big arrow. In traditional Jurchen hunting practices, since each warrior was allowed one arrow and nine warriors went out together under the leadership of a banner headman, niru later developed into the most rudimentary military unit, and niru ejen connoted the leader of each niru who gave out commands through banner signals. ${ }^{38}$

Even before the launching of large-scale Manchu conquests, these basic gentile institutions of Jurchen society underwent changes due to intertribal marriages, migration, and war, the last of which in particular took people beyond boundaries of the gentes they were originally born into, giving rise to a new identity based on place rather than original gens. The Manchu word gasan is precisely meant to denote the villages surrounding castles used for military defense. ${ }^{39}$ In the midI5th century, Jurchen settlements along the Tumen River were found to have members of different lineages within the same village. That is to say, while some villages were composed only of members from the same hala, others were a blend of people with different lineage ties. ${ }^{40}$

Although they shared similar social organizations and economic forms of life, Jurchens across tribes were by no means the same. Residing in the eastern and southern portions of Manchuria geographically most adjacent to Korean and Ming influence with richer

\footnotetext{
36 Elliott, The Manchu Way, 57.

37 Mo, Manzushi luncong, 65.

38 Zheng, Tanwei ji, I75.

39 Liu, Manzu cong buluo dao guojia de fazhan, 38.

40 Ibid., 52.
} 
soils, milder winters, and more plains suited to farming, the Jianzhou branch of Jurchens developed more advanced sedentary ways of life with a higher ratio of agriculture in their economy than other tribes. ${ }^{4}$ Their adjacency with the Ming, moreover, made possible their looting campaigns in Liaodong, from which Jurchens brought back both agricultural tools and people. ${ }^{42}$ By the mid-r6th century, intertribal competitions for resources were so intense that large-scale intertribal wars had begun, culminating in the dominance of the Jianzhou, the origins of later Manchu rule.

In sum, the hala and later the mukun, namely gentes for Manchus, were the basic institutions of Jurchen society by the mid-I $6^{\text {th }}$ century, complying perfectly with Engels's statement that "the gens is an institution common to all barbarians up to their entry into civilization. «\$3 Gentile institutions also played an important role in the social and economic lives of Jurchens. As the foregoing discussions have shown, hunting activities were organized based on gentile divisions, and the way that prey was distributed demonstrated that equality between tribal members was the rule of the day. ${ }^{44}$ Moreover, the emergence of gasan, namely villages in which residents were not necessarily from the same gens, shows the increasing complexity of Jurchen society. By this time, the organization of Jurchen society was not yet that of a state, and in fact a state was far from an evitable option. ${ }^{45}$ Most tribes never turned into a state until the rise of the Jianzhou branch, the one that first turned "habitual cooperation" among tribes into a regular "permanent league« and then continued to challenge the Ming rule. ${ }^{46}$

\footnotetext{
4I Huang, Reorienting the Manchus, IOI.

42 Mo, Manzushi luncong, 47.

43 Engels, Origin, 88.

44 Certain features of the Manchu gens before their conquest in the late I6th century remarkably resembled what Engels says about the Iroquois gens. Ibid., 88-92.

45 Ibid., 95-97.

46 Ibid., 96.
} 


\section{Early Conquests and Using "Banners" to Absorb New Population}

In the I570s, large-scale intertribal wars started. After Nurhaci (I559-1626) succeeded to the leadership of the Jianzhou branch in 1583, Jianzhou soon rose to supreme power in Manchuria. Having taken over a number of tribal city-states near his residence at Hulan Hada, he won a decisive victory over the allied army of Hulun Ssu Kuo in 1593, bringing home 3,000 horses and thousands of suits of armor while causing 4,000 casualties. Early victories gave Nurhaci not only prestige among Jurchen tribes but also booty to cover the costs of future expansions. ${ }^{47}$ Weaker tribes chose to surrender without resistance. In 1588, following the pledge of the Suwan chief, more tribes joined, bringing their people to Nurhaci's territory. ${ }^{48}$ Of the 66 tribes Nurhaci incorporated, 17 surrendered without resistance. ${ }^{49}$ In the years I599-I60I, he conquered the Hada and added charters of the surrendered to the 500 charters he already possessed, becoming the wealthiest chieftain in Manchuria. ${ }^{50}$ In 1607 he conquered the Hoifa, and finally, in I6I3, after he defeated Ula, the vast majority of Jianzhou and Haixi lands and people were brought under his control. ${ }^{\text {st }}$ A commander of an army of only 500 soldiers in 1583, within two decades, Nurhaci had unified all Jurchen tribes.

One strategy Nurhaci adopted was to absorb the conquered population without dismantling their social institutions. More specifically, what Nurhaci did was to organize newly subordinated groups into niru while keeping their old clan organizations intact. ${ }^{22}$ For example,

47 Arthur W. Hummel, Eminent Chinese of the Ching Period (I644-1912) (Washington DC: US Government Printing Office, 1943), 596.

48 Wang Xianqian, ed., Donghua lu, vol. I (Shanghai: Shanghai guji chubanshe, 2002 [I884]), I2.

49 Hideo Ishibashi, Shindai Chügoku no shomondai (Tokyo: Yamakawa shuppansha, I995), 25 .

50 Huang, Reorienting the Manchus, 70.

5 I Hummel, Eminent Chinese, 596.

52 Zhao Erxun, ed., Qingshi gao, (Beijing: Zhonghua shuju, I977 [1928]), 9232. 
in I593, while defeating the Zhusheli, Nurhaci moved its people to his own territories. In 1599, while conquering the Hada tribe, Nurhaci incorporated them into his household registration system. ${ }^{53}$ Through the transformation of the hunting niru into the military niru, Nurhaci infused into those previously dispersed Jurchen tribes a new relationship with the Manchu regime.

Meanwhile, Nurhaci allowed the headman of the conquered tribe to maintain his original status, namely to become the niru-ejen, the leader of the newly forged military company. For instance, in 1595/6, during his return tour from Jianzhou Jurchen, the Korean diplomat Shen Zhongyi wrote that under the leadership of the brothers Nurhaci and Surhaci, there were two hundred military headmen. All of them were old tribal chieftains and governed their own former tribal members. ${ }^{54}$ The tribal leaders were incorporated into the Jianzhou conquest regime, while old tribal organizations such as gasan, mukun and uksun were left undisturbed. A new identity to the conqueror's regime began to transcend the previous allegiance to the tribe. By bringing together people with diverse tribal affiliations and geographical origins, Nurhaci's conquest set in motion a remarkable political integration of Jurchen society. 55

As Nurhaci's military conquests progressed successfully, the niru organizations, originally hunting organizations, extended to other areas of Jurchen lives and gradually became a principal institution that worked to reconfigure Jurchen society and to rationalize the management of the Jurchen population. In 1616, the functions of niru companies extended to civilian areas. For example, in July of I616, Nurhaci asked each niru to dispatch three persons to help build 200

53 Zheng, Tanwei ji, IO-II.

54 Shen Zhongyi, "Jianzhou jicheng tuji, "in Qingchu shiliao congkan dishi, ed. Liaoning daxue lishixi (Shenyang: Liaoning daxue lishixi, 1979), 23.

55 Zhou Yuanlian, Qingchao xingqi shi (Changchun: Jilin wenshi chubanshe, 1986), II8-II9. 
boats. ${ }^{56}$ Other examples can be found in areas of agricultural production, public services, festival celebrations, military logistics, etc. For instance, in I6I3, Nurhaci asked each niru to send ten adult males and four cattle to cultivate wastelands. ${ }^{57}$ In 1622 , he asked each niru to offer three cattle as sacrifices for the end-of-year celebration..$^{58}$ Starting as the basic hunting unit of ten warriors, the niru later extended its application not only to military occasions to have 300 warriors in each of them but also to the general population as a unit of the equal distribution of public duties.

When conquests remained confined to Manchuria before I62I, conquered populations were divided largely by ethnic differences. The conquered Jurchens, or jusen in Manchu, were incorporated into the conquerors niru organizations, while Chinese, Koreans, and Mongolians, or ethnically non-Jurchens, became booi aha or household slaves of the conquerors. ${ }^{59}$ In other words, while the conquered from other Manchu tribes became jusen, enjoying a similar status to the old jusen of Nurhaci's original tribes, the non-Manchu conquered populations were subjugated as booi bondservants. The jusen population enjoyed a free status because a long-cherished tradition of pre-conquest Jurchen society was that Jurchens never enslaved their own men. ${ }^{60}$ For instance, in 1603 , after Nurhaci conquered the Hada tribe, he moved Hada people to regions adjacent to his residence and enrolled them in the already existing niru population registration system. Applying the same rule to the vanquished Huifa tribe, in 1607 Nurhaci »disarmed its troops but enlisted its people.« Having conquered the powerful

56 First Historical Archive, ed., Manwen laodang (Beijing: Zhonghua shuju, 1990), 47 .

57 Ibid., I9.

58 Ibid., 280 .

59 For a detailed semantic analysis of the word Manju and its relationship with jusen, see Ishibashi, Shindai chügoku no shomondai, I9-36.

6o Wang Zhonghan, ed., Chaoxian lichao shilu (Shenyang: Liaoning daxue lishixi, I979), I27. 
Ula tribe, in 1613 Nurhaci granted niru memberships to its "tens of thousands of households. « ${ }^{61}$

Generally speaking, before the conquests extended to areas with a non-Manchu population as a majority, the conquered population from other Manchu tribes was usually organized into niru organizations, while ethnically non-Manchu people, mostly Chinese and Koreans, were subjugated as booi aha. Incorporating the conquered population in such ways perfectly suited the Manchu regime during the early conquests when a regular tax system remained absent and public duties could be accomplished at the lowest possible cost. ${ }^{62}$

In 1619, Nurhaci won a decisive battle at Sarhu, his first major confrontation with the Ming court, which marked the beginning of the expansion of his conquests to the Han Chinese territory. That year, Nurhaci took over 70 fortified towns, including Fushun, Kaiyuan, and Tieling. Tens of thousands of Chinese as well as Koreans fighting for the Ming were captured. These captives were distributed as booi aha among the Manchu nobles and put to work on the private landed estates of Manchu nobles as agricultural slaves. ${ }^{63}$ This battle thus significantly expanded the booi aha population and fueled the growth of tokso while also creating a larger imbalance of wealth among the Manchus.

Upon taking over Mukden, Nurhaci laid claim to vacated and uncultivated lands, equalized land shares, and conducted a universal redistribution of lands. "Masterless" lands, left behind by the thousands of Liaodong people who had fled, were transformed into state-controlled lands. ${ }^{64}$ Similarly to what Engels says about the ways that Germans distributed land among themselves upon conquering Roman provinces, on July I $4^{\text {th }}$ of I62I, Nurhaci decreed a reclamation

6I Li Yanguang and Guan Jie, Manzu tongshi (Shenyang: Liaoning minzu chubanshe, I99I), I43.

62 Manwen laodang, 19, 37; Zheng, Tanweiji, 195-199.

63 Wang, Qingshi zakao, 24.

64 Kenneth M. Swope, The Military Collapse of China's Ming Dynasty, I6I8-44 (New York: Routledge, 20I4), 37-38. 
of 300,000 xiang (a Chinese equivalent of Io,000 square meters) of wasteland in Haizhou and distributed it to Manchu soldiers in residence. ${ }^{65} \mathrm{He}$ then extended the offer of land to Han Chinese from the previous five Liaodong garrisons, asking each recipient to pay a quota of grain in tax and corvee labor duties in return. ${ }^{66}$ In November, military duties were added to the mandatory service required from each adult male land recipient. ${ }^{67}$ The land redistribution was carried out only on "masterless" lands, based on the spirit of bringing the least disruption to the existing social order. ${ }^{68}$

Entering regions with a Han Chinese population as the majority changed the fiscal system of the conquering regime dramatically. The conquered land and population in Liaodong brought invaluable revenue and the manpower needed to build the public sector of the conquering regime. The land distribution and the subsequent tax collection were all patterned on the Ming model. ${ }^{69}$ In March of I62I, the land quota that each adult male received settled on five xiang of grain fields and one xiang of cotton fields. ${ }^{\circ 0}$ In addition, Liaodong people were also asked to pay corvee labor and undertake military service as assigned by the regime. ${ }^{71}$

The availability of agricultural revenues fueled the early development of bureaucracy. To establish tighter local controls, the Manchu regime followed the Ming practice of organizing commoners under hundred-man chiefs (baizhang), who represented the state in charge of local administration..$^{72}$ In I62I, to better handle ethnic relations, the crown founded the Bureau of Supreme Judges (Dutang yamen). This court was charged with providing residences for the Chinese, handling escapees, transporting military logistic supplies, harvesting

65 Engels, Origin, I42; Manwen laodang, 219.

66 Manwen laodang, 244.

67 Ibid., 256, 263.

68 Jin-liang, Manzhou midang (Taibei: Wenhai chubanshe, 1967), 60.

69 Zhou, Qingchao xingqi shi, 266.

70 Manwen laodang, 220.

7I Li and Guan, Manzu tongshi, 203.

72 Manwen laodang, $27 \mathrm{I}$. 
grain, and negotiating merchandise prices. ${ }^{73}$ In 1622,24 legal judges (duanshiguan) were appointed to supervise legal practices within banners. $^{74}$

The conquerors distributed lands among themselves, and their corvee labor duties were shifted to the conquered Chinese. Because of the taxes and corvee labor contributed by the Chinese, the Manchu jusen commoners enjoyed less tax and service burdens. Their duties could thus concentrate on those that were truly "Manchu s since the gentile age. Such labor included digging ginseng, hunting, raising horses, escorting trading tours, baking seawater, etc. ${ }^{75}$

Although progress in state-building had been made as the conquests expanded, the regime still only had limited tax resources, inevitably hampering the development of bureaucracy and supporting the continued strengthening of the old Manchu gentile rule of "eight privileges" (bafen). The rule of "eight privileges, "also called jakun $u b u$ in Manchu, which originated from the tribal hunting tradition, stipulated the equal distribution of spoils, lands, and people among the Manchu top leadership, a principle of property distribution commonly found in gentile societies. ${ }^{76}$ It functioned first as a principle of distribution of booty. Valuables from booty such as gold, silver, and silk were assembled, equally distributed to each hoiso beile (the commander of a banner) and finally through each individual beile into the hands of those who participated in the campaign. ${ }^{77}$ The rule soon became a set of overarching principles for organizing the new Manchu state. More specifically, the Manchu princes, primarily Nurhaci's sons and nephews, were granted one share of the eight equal portions of the political, economic, and legal power of the Manchu state. This

73 Yao Nianci, Qingchu zhengzhishi tanwei (Shenyang: Liaoning minzu chubanshe, 2008), IOI.

74 Ibid., 82.

75 Wang, Qingshi zakao, 20.

76 Similar military democracy was also found among Romans and Greeks. See Engels, Origin, I22-I23.

77 Manwen laodang, 95. 
system was officially confirmed in March of I622 when the eight hosoi beile were declared to be the central committee of the Manchu state. Under this structure, decisions on the imperial succession, state affairs generally, and serious legal cases not handled by lower courts were made collectively. ${ }^{78}$

While this principle offered a ruling solution for such a rudimental regime with only limited fiscal resources, it later ran counter to the strengthening of royal power, the latter of which became increasingly imminent for the consolidation of the regime's ever-expanding conquests. Within his own banner, the beile prince's power was unparalleled. He was both the owner of the largest estates and the master of the booi aha population within his own banner. To be sure, Manchu jusen commoners within a banner had to meet labor and other services demanded by the crown. But it was the beile prince who represented his banner at the imperial conference, and all public orders of the state had to be passed down through him. Therefore, under the system of the "eight privileges, " although the emperor did enjoy more public authority and his own yellow banner was widely acknowledged as being superior, he could not make arbitrary decisions. All state matters had to be discussed with the seven beile princes first. ${ }^{79}$ The Manchu emperor's power was so limited that a later Chinese advisor at the Manchu court quipped that the crown was no different from a beile prince of his own yellow banner. ${ }^{80}$ This consultative nature of the feudal confederacy of the early Manchu state, formalized with the establishment of the Eight Banners System, planted the seeds of the future political crisis.

When first entering Liaodong in I62I, Nurhaci did attempt to continue the old practices of subjugating all captives as serfs into Manchu princely estates, or tokso in Manchu. Between I62I and I625, the regime suffered from an extreme grain shortage, and the insuffi-

78 Ibid., 345-348.

79 Meng Sen, Mingqingshi lunzhu jikan (Beijing: Zhonghua shuju, 1959), 218.

80 Luo Zhenyu, ed., Tiancong chao chengongzouyi (Taibei:Tailian guofeng chubanshe, I968), 276. 
cient development of the tax-collecting bureaus worsened the problem. To meet the financial needs of the military emergency, the ruler had to reorient his fiscal plan back to the "eight privileges" principle by subjugating the Chinese to be agricultural slaves on private princely estates. ${ }^{81}$ According to this policy, all Chinese and their lands were reorganized into equal-sized landed estates, each equipped with Ioo xiang of lands, 13 adult males, and 7 oxen. These new estates were then distributed to all Manchu military nobles based on their rank. ${ }^{82}$ When the taxes collected from the agricultural production of the Ming model could not meet the requirements of the state's budget, the old mode of production, featured by a promotion of the growth of privately owned landed estates and the use of forced bondservant labor, returned. ${ }^{83}$

This policy immediately provoked Chinese resistance and significantly reduced agricultural productivity, making the existing grain shortage even worse. ${ }^{84}$ Intimidated by the oppressive Manchu policy in I625, more Chinese fled, the incentive to work dropped, and harvests hit a new low. ${ }^{85}$ This policy granted more economic autonomy to beile princes. The economic power of the Manchu nobility soared, but at the cost of undermining the public coffers of the regime. On the newly formed princely estates, tax-collecting power fell into the hands of beile princes, accelerating fiscal decentralization. ${ }^{86}$ In short, as conquests continued to expand, applying old gentile organizations to incorporate the conquered population was confronted with resistance and chaos. Thus, the Manchu population policy in the years I62I-I625 showed that the old practice of turning the non-Manchu population into household slaves was meeting its limits.

\footnotetext{
8I Jin-liang, Manzhou midang, 73.

82 Manwen laodang, 644.

83 Zhou, Qingchao xingqi shi, 347, 351.

84 Ibid., 345, 347; Wu Tingyu et al, eds., Qingdai manzhou tudi zhidu yanjiu (Changchun: Jilinwenshi chubanshe, 1993), 29.

85 Manwen laodang, 858.

86 Meng, Mingqingshi lunzhu jikan, 233.
} 


\section{Continued Conquests, Dismantled Gentile Constitution, and the Rise of Royal Power}

In The Origin of the Family, Private Property, and the State, Engels suggests that among many other favorable factors for the rise of royal power that arose from military conquests, there was one institution that especially favored it: "the retinue. ${ }^{87}$ In regards to the mechanism of continued warfare and the rise of royal power, Engels writes: "The military commander who had acquired fame gathered around his person a host of booty-loving young warriors pledged to loyalty to him personally, as he was to them. He fed them, gave them gifts and organized them on hierarchical principles: a bodyguard and a troop ready for immediate action in short expeditions, a trained corps of officers for larger campaigns. ${ }^{88}$ Never-ending conquests were necessary, because, as Engels explains, "they could be held together only by continuous warfare and plundering expeditions. ${ }^{89}$

As early Manchu conquests remained confined to Manchuria, several factors conducive to the strengthening of the ruling power had already arisen. The first was the booi or bondservants of the Manchu ruler. Most Chinese booi came from captives taken between I618 and I62I in Fushun and Shenyang, constituting the main staffing for the later establishment of the Qing Imperial Household Department (neiwufu). ${ }^{90}$ The booi were among the earliest followers of Nurhaci's military career. In 1584, when an assassin posed a security threat to Nurhaci, it was his booi niyalma that protected him from being harmed. ${ }^{91}$ During the time when supplies of Jurchen soldiers fell short, it was the booi who either fought shoulder to shoulder with

\footnotetext{
87 Engels, Origin, 136.

88 Ibid.

89 Ibid.

90 Preston M. Torbert, The Ch'ing Imperial Household Department: A Study of its Organization and Principal Functions, I662-1796 (Cambridge, MA: Harvard University Press, 1970), I6-I7.

9I Manzhou shilu, 9.
} 
their masters or provided logistical support. The booi also engaged in collecting war spoils for their masters..$^{92}$ In the early days of Nurhaci's career, when well-equipped and organized troops fell short, it was his booi warriors who played a crucial role in securing his early victories. ${ }^{93}$ By serving as his private security guards, personal servants, and more generally as a category of the population that was only supposed to owe their service to the leader, booi played a role in the rise of Nurhaci's power.

Personal agents of a similar kind also included the khan's private guards, known as bayara. The word bayara means guard or troops on guard duty. In organizational terms, bayara were selected based on military merit from each niru to undertake public duties. The bayara warriors were recruited from each niru to meet a variety of military duties. ${ }^{94}$ In 1635, after the division between the Upper Three Banners and the Lower Five Banners was made, the institutional structure of the bayara troops was changed correspondingly. ${ }^{95}$ After the Manchu state became a national regime in I644, the Upper Three bayara troops (Bordered Yellow, Plain Yellow, and Plain White) became privy security guards of the emperor. ${ }^{96}$

In The Origin of the Family, Private Property and the State, Engels not only shows that the emergence of the state was the result of the development of private property, but the accumulation of wealth into the military commander's hands facilitated it. ${ }^{97}$ The early rise of Manchu power evinces this aspect. More specifically, through the monop-

92 Du Jiaji, Baqi yu qingchao zhengzhi lungao (Beijing: Renmin chubanshe, 2008), 95.

93 Zheng, Tanwei ji, III.

94 Korehiro Anami, Shinsho gunji shi ronkō (Tokyo: Kōyō shobō, 1980), I8I.

95 For documental evidence of the division between Upper Three and Lower Five Banners and its influence on the founding of the Imperial Household Department, see Meng, Mingqingshi lunzhu jikan, 243. Also see Jonathan Spence, Ts'ao Yin and the K'ang-hsi Emperor, Bondservant and Master (New Haven, CT: Yale University Press, I978), Io.

96 Zheng, Tanwei ji, I87.

97 Engels, Origin, I06-IO7. 
olized control of Jurchen special products such as ginseng, pearl, and furs and other measures to expand his fiscal resources, Nurhaci gained crucial funding for his early military successes. A special Jurchen article that perhaps played the greatest role in Nurhaci's rise was ginseng. In the I6th century, the Ming court's high demand for ginseng supplies gave this product a great market value..$^{98}$ Abundant evidence shows that the rise of Nurhaci's power went hand in hand with his success in the ginseng business. "At the age of nineteen, Nurhaci is said to have left his father to trade in ginseng at the Fushun horse market. «99 By the I590s, "Nurhaci had already amassed a great fortune by monopolizing the trade in pearls, ginseng, fur, etc.; by mining; by taking silver in return for his yearly tribute to the Ming court; and by pillaging weaker tribes. ${ }^{100}$ In particular, by inventing a new method of preserving ginseng, Nurhaci was able to sell it more dearly, which brought him more profits. ${ }^{\text {ior }}$ By the end of the I6th century, Ming officials had already noticed that it was Nurhaci's monopolization of ginseng on frontier horse markets that gave him dangerous economic power. Witnessing the Jurchen threat looming large in the I620s, the Ming official on the Liaodong Peninsula, Cheng Kaihu, wrote, "Nurhaci (nuqiu) had long been wealthy and powerful by monopolizing profits of furs and ginseng. $«^{\text {102 }}$

The emergence of retinues or private bodyguards and the "robbery of wealth" by the supreme military commander, as Engels has shown, were but by-products of continued conquests. It was the latter that, in the end, shattered the old gentile institutions, which for a long

98 Van Jay Symons, »The Ch’ing Ginseng Monopoly« (PhD diss., Brown University, I974), I2I.

99 Ibid., I22.

Ioo Hummel, Eminent Chinese, 596.

IOI Zhou Yuanlian, Qingchaokaiguoshiyanjiu (Shenyang: Liaoning renmin chubanshe, I98I), 58 .

IO2 Cheng Kaihu, "Dongyi nu'erhachi kao, in Qing ruguan qian shiliao xuanji, vol. I, ed. Pan Zhe, Li Hongbin and Sun Fangming (Beijing: People's University Press, 1985), 106. 
time before the conquest had played an overarching role in shaping Manchu society. ${ }^{103}$

When Abahai (1592-1643), Nurhaci's eighth son, succeeded to the throne in 1627 , tribal military democracy remained the political ethos that dominated the regime. On his deathbed, Nurhaci issued a set of instructions that granted more economic and political power to the beile princes with the »eight privileges." He believed that it was a collegial rule, in which all the banner princes were to have an equal voice in policy formation, rather than an imperial system that helped guarantee the political success of the Manchu state. He urged the various princes to share the wealth acquired equally as their state expanded and to remonstrate with each other if any wrongdoing occurred. ${ }^{104}$

Such a principle of collegial rule made the beile princes the equal beneficiaries of the thrones and lands of all subjugated peoples; nonetheless, it also reflected the fiscal limits of the Manchu regime and its inability to afford a fully functional bureaucracy. In I634, responding to a criticism that the Manchu state cared more about taking wealth for the ruler alone rather than for building stronger public coffers, Abahai's Chinese advisor explained, "Because lands of our state have not expanded enough and people are still struggling for existence, the day that Ming taxation system being applied in our state has not yet come. $\varkappa^{105}$ In the 1620-1630s, this immature fiscal system left the Manchu state no choice but to adopt a fiscal policy called »raising people by eight banners" (baqi fenyang guoren; Manchu: ujimbi), namely to let the eight beile princes share both the burdens of state administration and the power of the state.

After 1627, Manchu conquest entered a golden era, marked by a string of new military successes in regions with majority Chinese and Mongol populations. In I630, Abahai went on to conquer the towns

I03 Engels, Origin, I07.

IO4 Taizong shilu, 4 .

I05 Taizong shilu, 301 . 
of Luanzhou and Qian'an, among others. ${ }^{106}$ The year I63I saw his splendid victory in the Siege of Dalinghe. ${ }^{107}$ These military successes brought about a significant change to the previous structure of the Eight Banners System, the institutional bulwark of the old principle of "eight privileges, " which remained untouched when Abahai succeeded the throne.

The first change was the addition of the eight Mongol banners. In I62I, two Mongol niru companies were formed from 645 Mongol households of the Kalga tribe brought to the Manchu state. ${ }^{108}$ The years after 1622 saw a large-scale incorporation of the Mongol population into the Manchu regime. In I63I, two separate Mongol banners (menggu erqi), detached from the Manchu banners, were established. ${ }^{109}$ In 1635, the Mongol banners expanded to eight, paralleled with the already existing eight Manchu banners. ${ }^{\text {IIO }}$

The second change, related to the first, was to create eight Chinese banners, which shaped the Manchu regime in a more profound way. For the first few decades in the history of the Manchu conquest, when it came to the issue of Chinese captives, the usual approach adopted by the Manchu regime was simple but brutal: either to kill them all or to subjugate them as bondservants. ${ }^{\text {III }}$ The first significant change occurred after the Siege of Liaodong in I62I. Then, after Abahai assumed his rule in 1627 , there developed a clear tendency for Chinese institutions to rise up in the Manchu state machinery. The year I628 saw the first civil service exam organized by the Manchu regime to select Chinese talents with a booi status to serve in Manchu bureaus. ${ }^{\text {II }}$ As the conquest regime expanded to the Ming territories, the Manchu ruler gradually turned from the old co-habitancy policy of Manchus

Io6 Chen Jiahua and Fu Kedong, "Baqi hanjun kaolve, in Manzushi yanjiuji, ed. Wang Zhonghan (Beijing: Zhongguo shehui kexue chubanshe, I988), 290.

IO7 Manwen laodang, II3I-57.

I08 Yao, Qingchu zhengzhishi tanwei, I58; Wang, Qingshi zakao, II9.

Io9 Yao, Qingchu zhengzhishi tanwei, I58-I59.

IIO Ibid., I59-I60.

III Manwen laodang, 62.

II2 Yao, Qingchu zhengzhishi tanwei, I6I. 
and Chinese to the idea of establishing separate Chinese banners. In 1637, the number of Chinese banners increased to two, four in I639, and finally eight in 1642 .

The establishment of eight Mongol and Chinese banners not only signified a new way by the Manchu regime to incorporate a conquered population who were ethnically different, but also provided leeway for the throne to break the collegial rule with seven top Manchu nobles and centralize power in his own hands. One telling example of how the incorporation of the conquered populations changed the nature of the regime was the establishment of three additional Mongol banners that did not fall under the jurisdiction of the »eight privileges" and were under the throne's direct control. That is, while the total number of male adults of the eleven Mongol banners formed in 1635 was 16,953 , the three Mongol banners falling outside the »eight privileges" had 9,I23 male adults, making up more than half of the total. ${ }^{113}$ More evidence suggests that this practice as to the organization of Mongol banners later became the norm. ${ }^{\mathrm{II} 4}$ In addition, in I636, the three outside vassal Mongol banner leaders were granted imperial titles by the throne, forging a tangible sense of personal loyalty among the banner leaders to the throne. ${ }^{\text {II }}$ All of this helped to enlarge the crown's personal authority and to gain an upper hand over the princes.

A similar arrangement was found in the establishment of the Chinese banners. In 1633, after Kong Youde (1602-1652), Geng Zhongming (?-I649), Shang Kexi (I604-I676) and Shen Zhixiang (?-I648), the four high-ranking frontier officials of the Ming, shifted loyalty to the Manchu, they were organized into special Chinese banners that fell outside of the jurisdiction of the »eight privileges." In Man$\mathrm{chu}$, the relationship between Chinese bannermen and their Manchu banner leader was called ujimbi, a paternal relationship in which the Manchu banner leader was the giver of a livelihood. However, the Chinese bannermen who were in the ranks of special Chinese banners

II3 Qi Yunshi, Huangchao fanbu yaolve (Taibei: Wenhai chubanshe, I965), 2I.

II4 Tayama, Shindai ni okeru Möko no shakai seido, 79-8I.

IIs Du, Baqi yu qingchao zhengzhi lungao, II2. 
were different, because the sole authority for them was the Manchu imperial court. ${ }^{\mathrm{II}}$

Thanks to the large-scale incorporation of the Chinese and Mongol population into the Manchu regime during this period, Abahai began to break up the dominance of the »eight privileges « in the political system and to exceed his own power over the princes by controlling more people, lands, and revenues. In I627, Abahai established eight senior ministers ( $b a$ dachen) and eight banner lieutenant-generals (gusan $i$ ejen) to be dispatched to each banner under the guise of assisting beile princes on banner affairs. He further established the new offices of I6 senior officials (shiliu dachen), designed to work with banner leaders on military affairs and judicial inquisitions. ${ }^{\mathrm{II7}}$ Through these arrangements, the imperial power began to have a strong presence within the banners. The old political order in which princes had hereditary control over their bannermen and enjoyed absolute administrative autonomy within their banners began to be challenged. ${ }^{\text {II8 }}$

As territories of the regime expanded, Abahai also acquired a greater fiscal base to carry his centralization agenda even further forward. In I629, the Three Inner Courts (nei san yuan), a modified version of the previous Literary Office (wenguan), were established, charged with offering administrative advice and secretarial assistance to the crown. ${ }^{\text {II9 }}$ Thereafter, this literary bureau became increasingly attractive to Chinese talents who were familiar with Confucian statecraft and offered them an opportunity to play an advisory role in the decision-making of the Manchu court. The year I63I saw the establishment of Six Boards (liubu; Manchu: ninggun jurgan) on the Ming

II6 Zhang Jinfan and Guo Chengkang, Qing ruguanqian guojia falv zhidushi (Shenyang: Liaoning minzu chubanshe, 1988), 398-404; Chen Jiexian, Huangtaiji xiezhen (Taibei: Yuanliu chubanshe, 2004), I6I-I62; Chen, Mingqing zhengzhi shehui shilun, vol. 2, 48I.

II7 Taizong shilu, 6.

II8 For a discussion of the actual overlapping staffing during Nurhaci's reign between banner officers and court officers, see Chen, Mingqing zhengzhi shehui shilun, 437 .

II) Zhang and Guo, Qing ruguanqian guojia falv zhidushi, 83-86. 
model, a milestone in the development of the administrative machinery of the Manchu state. Upon his Chinese advisor's advice, Abahai went on to establish the Censorate (ducha yuan) in 1636, an independent bureau that supervised and impeached the misconduct of Manchu nobles and state officials. ${ }^{120}$ Despite the Manchu dominance, the staffing of the Six Boards did enjoy a broad ethnic representation. More importantly, for the first time, Chinese advisors made their way to the top administrative bureaus of the Manchu court, and the later trajectory of the development of the Manchu state did prove that they were the best allies for Abahai's scheme of centralization. ${ }^{\text {I2r }}$

As Abahai took those forceful steps to subdue the powerful hosoi beile princes and placed bureaucratic constraints on them, the principle of the "eight privileges" itself began to change. In I631, Abahai made a major modification to this principle by granting imperial protection to any individual who stepped forward to be open about any misconduct of the beile princes. ${ }^{122}$ This revision of the "eight privileges « began to loosen the autonomy of the princes patrimony and thereby placed the princes under the surveillance of the state's laws. In I634, Abahai began to revise the time-honored Manchu practice that the eight princes should share power and wealth equally, and replaced it with one whereby any benefit acquired from conquests should go to the "deficient banners" (buzu zhi qi) first. ${ }^{123}$ This change gave the Manchu emperor the discretion to decide which banner should be considered as »deficient, " representing the start of the imperial intervention of the economic jurisdiction of the "eight privileges." In I635, the state's law further deemed the act of hiding the population as bondservants in order to evade the state's taxes, which was widely

I20 See Xu Mingyuan's memorial dated February 22, I634 in Luo, Tiancong chao chengong zouyi, 399-40I.

I2I For a chart of Manchu, Chinese, and Mongol officials who were appointed to the Six Boards in I63I, see Zhang and Guo, Qing ruguanqian guojia falv zhidushi, 55 .

I22 Taizong shilu, 153 .

I23 Zhongguo diyi lishi dang'anguan, ed., Qingchu neiguoshiyuan manwen dang'an yibian, vol. I (Beijing: Guangming ribao chubanshe, 1989), III. 
prevalent in banners as a way to increase the princes personal wealth, as illegal. ${ }^{124}$ By making those profound revisions to the "eight privileges, " the imperial power strengthened its control over the clan rule. The feudal and decentralizing tendency of the clan rule, formed and buttressed by the Eight Banners System, was effectively constrained.

Despite Abahai's gains, the fashioning of imperial power was not completed within his reign, because the crown's advantage in terms of the sheer number of banners he possessed was not yet dominant. ${ }^{125}$ The limits of the accomplishments achieved by Abahai toward a centralized throne were best reflected in the succession crisis following his death in I643. Instead of being set by the deceased crown's testamentary edict, his son's succession was decided by a joint conference of powerful nobles. ${ }^{126}$ Abahai's centralization efforts had met their limits, because the throne had not taken control of an economy strong enough to build an efficient bureaucracy. This inevitably led to the economic reliance of the crown on the financial support of the princes. When the Manchu regime first entered Beijing in I644, a symbolic event of the establishment of the Qing rule, the regime still faced mounting fiscal challenges, which left Shunzhi (I638-I66I) no option but to turn to the princes for help. ${ }^{127}$

It was the turning into a national regime that fundamentally changed the fiscal bases of Manchu rule. Upon taking over Beijing, Manchu rulers made systematic efforts to restore the tax collection on the Ming model. ${ }^{\mathrm{I} 28}$ By I66I, the last year of the Shunzhi emperor's

I24 Ibid., I48. For a decree concerning this problem in I635, see Nobuo Kanda, Jun Matsumura, and Hidehiro Okada, eds., Kyū Manshūtō (Tokyo: Tōyō bunko, 1972), 6I. For a legal case in I639 concerning the state's intervention in the tax evasion problem, see First Historical Archive, ed., Shengjing xingbu yuandang (Beijing: Qunzhong chubanshe, I985 [I639-I640]), I8I.

I25 Yao, Qingchu zhengzhishi tanwei, 252-53.

I26 Robert Oxnam, Ruling from Horseback: Manchu Politics in the Oboi Regency, I66I-1669 (Chicago: University of Chicago Press, I975), 38-40.

I27 Shin'yo jokei (Seoul: Keijo Teikoku Daigaku Hobun Gakubu, 1935), 425.

I28 Frederic Wakeman, Jr., The Great Enterprise: The Manchu Reconstruction of Imperial Order in Seventeenth-Century China (Berkeley: University of California Press, I985), $4 \mathrm{I} 6$. 
reign, the total count of agricultural lands had reached 549,357,640 $m u$ (one $m u$ is roughly equivalent to 66.7 square meters). The gap compared to the count of $701,397,628 m u$ in 1578 is largely due to the exclusion of lands still under the control of the Southern Ming court at the time. ${ }^{129}$ This data suggests that in the first two decades of the Qing dynasty's rule, taking control of the national economy gave the Manchu throne the fiscal resources it needed to build a fully functioning bureaucracy.

The expansion of the fiscal base of the Qing state in the post-I644 era fundamentally changed the power balance between the throne and the nobility in general, and the nature of the Eight Banners System in particular. The years I643-165I saw a remarkable reduction in the number of princely power contenders and continued tendencies to gravitate power toward the throne, laying the foundation for the Upper Three Banners after the young Shunzhi emperor assumed his personal rule. ${ }^{\mathrm{I} 0}$ In the post-I644 period, while each bannerman was granted a piece of banner land as their salary farm, they also began to receive silver or rice salaries directly from the crown. Initially only granted to cavalry soldiers, offers of silver or rice stipends extended to craftsmen, infantrymen, guards, and armored soldiers, although the salary gap still existed, with a soldier's monthly salary being two tales and a craftsman's salary only one tale. ${ }^{131}$ A significant salary increase occurred after the Qing defeated the Southern Ming court (1644-1662), because this victory, by expanding tax-collecting areas to South China, brought the Qing more revenues. ${ }^{132}$

I29 Liang Fangzhong, Zhongguo lidai hukou tiandi Tianfu tongji (Shanghai: Shanghai renmin chubanshe, 1980), 34I, 380.

I30 The three banners were his own Plain White banner, with the new additions of Plain Blue (preceded by Manggultai) and Bordered White (preceded by Dodo).

I3I Fu Lehuan, Liaoshi congkao (Beijing: Zhonghua shuju, I984), 4I9.

I32 For scholarly literature on the Southern Ming, a loyalist movement that was active in South China following the collapse of the Ming Dynasty in I644, see Lynn A. Struve, The Southern Ming, I644-1662 (New Haven, CT: Yale University Press, 1984); Wakeman, Jr., The Great Enterprise, 319-4I3. 
The changes to the military and political systems of the regime were also seen in the establishment of the Green Standard Army (lvying), a centralized army recruited exclusively from the Chinese population. ${ }^{133}$ The earliest recruits came from those who had surrendered from the Ming army, later joined by recruits who opted to do so as a way of making a living. ${ }^{134}$ Unlike Manchu bannermen, soldiers in the Green Standard Army received salaries paid in monetary cash and/or in rice directly from the state fiscal system. ${ }^{35}$ In 1654 , the number of Green Standard Army soldiers became triple that of Manchu banner soldiers. To feed the new troops, the Qing government paid an annual salary of II,5I8,400 tales in silver. Although the Qing government occasionally sought new financial sources to supplement the salary payments by selling offices (juanna) and opening up wasteland, in general, the majority of Chinese soldiers salaries were distributed by the Board of Revenue. ${ }^{136}$ Since the salaries of the soldiers came from the government, not the princes, they became the crown's soldiers, not to be compromised by the rule of the »eight privileges " anymore.

This changed power balance between the crown and the princes was immediately seen in the creation of new government regulations, designed to further check the influence of the princes in state affairs. In I651, the Shunzhi emperor decreed that bureaucrats working in a banner did not have to come from the same banner. For example, a plain yellow bannerman could have an appointment in the plain white banner, a bordered yellow bannerman could have the same in the plain yellow banner, etc. Since then, the princes began to lose personal control of personnel and appointments within their own

I33 Luo Ergang, Lvying bingzhi (Shanghai: Commercial Press, 1937), 26.

I34 Ibid., I7.

I35 The earliest record about the salaries of Green Standard Army soldiers was found in I654, which was II,518,400 tales of silver. For sources of Green Standard Army soldiers` salaries, see Lai Fushun, "Qingchu lvying bingzhi« (MA diss., Institute of Literary Studies of Private Chinese Culture College, Taibei, 1977), I67. For a representative view concerning the importance of the Manchus privileged identities as the conquerors, see Elliott, The Manchu Way, 2-13, 175-209.

I36 Lai, "Qingchu lvying bingzhi, « I68. 
banners. By I65I, the princes had even lost their power in the imperial decision-making process. Thereafter, they took part in discussions on state affairs only as high-ranking state officials, not in the same way as they used to in the Deliberative Council of Princes. ${ }^{137}$ In I65I, the incumbent of the Manchu throne both nominally and in reality established his imperial authority, not by strengthening the gentile military democracy that facilitated the conquest in its early stages, but by passing beyond it: "the gentile order was finished " and "the state took its place. $\aleph^{\mathrm{r} 38}$

\section{Conclusion}

Engels's The Origin of the Family, Private Property, and the State provides invaluable insights on the politico-economic aspects of the early Qing state-building process and, more generally, on the transition from the Manchu tribal society to the state. First, recognizing the fact that the pre-conquest Manchu society was fundamentally tribal and no exception to what Engels says about pre-state social organizations gets to the very root of the nature of the Eight Banners System, a trademark Manchu institution, which recent Qing historiography has regarded as the key to the maintaining of the Manchu ethnic identity throughout the dynasty and thus to the understanding of the nature of the Qing rule. The foregoing discussion has shown that, originating in the Manchu tribal era, the banners were, by origin, a constellation of gens-based hunting units. Using hunting units as early regime-building bases was not uncommon to other minority conquest groups in world civilizations, nor, after the state was in place, was the lasting influence of the "Manchu Way, " namely certain virtues such as toughness and virility in hunting and tribal life, unique. When discussing how the Athenian state arose to replace the gentes,

I37 Du, Baqi yu qingchao zhengzhi lungao, 257-259.

I38 Engels, Origin, I37. 
Engels argues that although »the organs of the gentile constitution were eliminated from public affairs ... their moral influence, the traditional conceptions and views of the old gentile period, survived for a long time and expired only gradually. ${ }{ }^{139}$ It was rather common among many other minority conquest groups for the "gentile mentality « to linger in its influence on the new social condition, despite the fact that "organs of the gentile constitution" were being transformed into organs of the state, and, for the benefit of the conquerors, this had to be done "quickly. ¿40 $^{\text {40 }}$

My second point is that only by coming to the gentile root of the Eight Banners System can we fully understand the Qing state-building process in the first half of the 17 th century. More specifically, I have argued that although tribal organizations such as banners played a crucial role in absorbing conquered populations when conquests remained confined to Manchuria, such organizations met their limits after the conquests extended to regions with a Han Chinese population as a majority, because, to borrow Engels's words, it was impossible to absorb the entire mass into "gentile bodies" or to "rule them with the aid of the latter. ${ }^{\mathrm{I} 4 \mathrm{II}}$ As Engels suggests, »[a]s soon as society passed beyond the limits for which this constitution sufficed, the gentile order was finished. It burst asunder and the state took its place. ${ }^{142}$ Our story above precisely shows that the Qing state arose not by sticking to or enhancing the gentile rule of »eight privileges, " but by undermining it. In sum, Engels's insights on the economic bases of the transition of the tribal society into the state remain relevant, not only to early civilizations but also to a minority conquest regime in early modern China. While certainly not intending to offer a universal theory to explain all the complex and diverse paths of tribes transitioning into states, Engels's work at least can serve to enlighten the importance of getting to the politico-economic roots of

\footnotetext{
I39 Ibid., II5.

I4O Ibid., I43, I46.

I4I Ibid., I43.

I42 Ibid., I37.
} 
certain ethnically colored institutions. In this case, it was those politico-economic forces that motivated the transition of Manchu society from tribe to state that determined the manner and degree to which a particular ethnic identity influenced the new order- not vice versa.

\section{Works Cited}

Anami, Korehiro. Shinsho gunji shi ronkō. Tokyo: Kōyō shobō, r98o.

Chen, Jiahua and Fu Kedong. "Baqi hanjun kaolve."In Manzushi yanjiuji, edited by Wang Zhonghan. Beijing: Zhongguo shehui kexue chubanshe, I988.

Chen, Jiexian. Huangtaiji xiezhen. Taibei: Yuanliu chubanshe, 2004.

Chen, Wenshi. »Qingtaizong shidai de zhongyao zhengzhi cuoshi.«In Chen Wenshi, Mingqing zhengzhi shehui shilun, vol. 2. Taibei: Taiwan xuesheng shuju, I99I.

Crossley, Pamela. A Translucent Mirror: History and Identity in Qing Imperial Ideology. Berkeley: University of California Press, 1999.

Du, Jiaji. Baqi yu qingchao zhengzhi lungao. Beijing: Renmin chubanshe, 2008.

Elliott, Mark. The Manchu Way: The Eight Banners and Ethnic Identity in Late Imperial China. Stanford: Stanford University Press, 200I.

Engels, Friedrich. The Origin of the Family, Private Property, and the State. Chippendale, Australia: Resistance Books, 2004.

First Historical Archive, ed. Manwen laodang. Beijing: Zhonghua shuju, I990.

First Historical Archive, ed. Shengjing xingbu yuandang. Beijing: Qunzhong chubanshe, 1985 [1639-1640].

Fu, Lehuan. Liaoshi congkao. Beijing: Zhonghua shuju, 1984.

Hummel, Arthur W. Eminent Chinese of the Ching Period (I644-19I2). Washington DC: US Government Printing Office, 1943.

Ishibashi, Hideo. Shindai Chägoku no shomondai. Tokyo: Yamakawa shuppansha, I995.

Jin-liang. Manzhou midang. Taibei: Wenhai chubanshe, 1967.

Kaihu, Cheng. "Dongyi nu' erhachi kao." In Qing ruguan qian shiliao xuanji, vol. I, edited by Pan Zhe, Li Hongbin and Sun Fangming. Beijing: People's University Press, 1985. 
Kanda, Nobuo, Jun Matsumura, and Hidehiro Okada, eds. Kyū Manshūtōo. Tokyo: Tōyō bunko, 1972.

Lai, Fushun. "Qingchu lvying bingzhi.» MA diss., Institute of Literary Studies of Private Chinese Culture College, Taibei, 1977.

Li, Yanguang and Guan Jie. Manzu tongshi. Shenyang: Liaoning minzu chubanshe, I991.

Liang, Fangzhong. Zhongguo lidai hukou tiandi Tianfu tongji. Shanghai: Shanghai renmin chubanshe, 1980.

Liu, Xiaomeng. Manzu cong buluo dao guojia de fazhan. Beijing: Zhongguo shehui kexue chubanshe, 2007.

Liu, Xiaomeng. Manzu de shehui yu shenghuo. Beijing: Beijing tushuguan chubanshe, 1998.

Luo, Ergang. Lvying bingzhi. Shanghai: Commercial Press, 1937.

Luo, Zhenyu, ed. Tiancong chao chengong zouyi. Taibei: Tailian guofeng chubanshe, 1968.

Manzhou shilu, comp. by reign. Reprint. Taibei: Huawen chubanshe, I964.

Meng, Sen. Mingqingshi lunzhu jikan. Beijing: Zhonghua shuju, I959.

Michael, Franz. The Origin of Manchu Rule in China: Frontier and Bureaucracy as Interacting Forces in the Chinese Empire. New York: Octagon Books, 1965 .

Mo, Dongyin. Manzushi luncong. Beijing: Renmin chubanshe, 1958.

Ortai et al., eds. Baqi manzhou shizu tongpu. Shenyang: Liaohaichubanshe, 2002 [1744].

Oxnam, Robert. Ruling from Horseback: Manchu Politics in the Oboi Regency, 166I-1669. Chicago: University of Chicago Press, I975.

Pei, Huang. Reorienting the Manchus: A Study of Sinicization, I583-I795. Ithaca, NY: Cornell University Press, $201 \mathrm{I}$.

Qi, Yunshi. Huangchao fanbu yaolve. Taibei: Wenhai chubanshe, 1965.

Rawski, Evelyn S. The Last Emperors: A Social History of Qing Imperial Institutions. Berkeley: University of California Press, 1998.

Shen, Zhongyi. "Jianzhou jicheng tuji.»In Qingchu shiliao congkan dishi, edited by Liaoning daxue lishixi. Shenyang: Liaoning daxue lishixi, I979.

Shin'yo jokei. Seoul: Keijo Teikoku Daigaku Hobun Gakubu, 1935.

Spence, Jonathan. T'ao Yin and the K'ang-hsi Emperor, Bondservant and Master. New Haven, CT: Yale University Press, 1978. 
Struve, Lynn A. The Southern Ming, I644-1662. New Haven, CT: Yale University Press, 1984.

Swope, Kenneth M. The Military Collapse of China's Ming Dynasty, I6I8-44. New York: Routledge, 2014.

Symons, Van Jay. "The Ch'ing Ginseng Monopoly." PhD diss., Brown University, 1974.

Taizu shilu, comp. by reign. Reprint. Taibei: Huawen chubanshe, 1964.

Torbert, Preston M. The Ching Imperial Household Department: A Study of its Organization and Principal Functions, I662-I796. Cambridge, MA: Harvard University Press, 1970.

Wakeman Jr., Frederic. The Great Enterprise: The Manchu Reconstruction of Imperial Order in Seventeenth-Century China. Berkeley: University of California Press, 1985.

Waley-Cohen, Joanna. »The New Qing History.« Radical History Review 88 (2004): 193-206.

Wang, Xianqian, comp. Donghua lu. Shanghai: Shanghai guji chubanshe, 2002 [1884].

Wang, Zhonghan, ed. Chaoxian lichao shilu. Shenyang: Liaoning daxue lishixi, I979.

Wu, Tingyu et al., eds. Qingdai manzhou tudi zhidu yanjiu. Changchun: Jilinwenshi chubanshe, 1993.

Yao, Nianci. Qingchu zhengzhishi tanwei. Shenyang: Liaoning minzu chubanshe, 2008.

Zhang, Jinfan and Guo Chengkang. Qing ruguanqian guojia falv zhidushi. Shenyang: Liaoning minzu chubanshe, 1988.

Zhao, Erxun, ed. Qingshi gao. Beijing: Zhonghua shuju, I977 [1928].

Zhao-lian. Xiaoting zalu. Beijing: Zhonghuashuju, 2017 [I8I4-1826].

Zhongguo diyi lishi dang'anguan, ed. Qingchu neiguoshiyuan manwen dang'an yibian, vol. I. Beijing: Guangming ribao chubanshe, 1989.

Zhou, Yuanlian. Qingchao kaiguoshi yanjiu. Shenyang: Liaoning renmin chubanshe, I98I.

Zhou, Yuanlian. Qingchao xingqi shi. Changchun: Jilin wenshi chubanshe, 1986. 


\section{Acknowledgements of Funding Supports}

This work is supported by the National Social Science Fund of China (20CZSo36), Shandong Social Science Planning Fund Program (19BYSJ56), and the Fundamental Research Funds of Shandong University (2018TBO27). 


\title{
The Contribution of Engels to the Critique of Political Economy ${ }^{1}$
}

\author{
Renildo Souza
}

Friedrich Engels, at the age of 24, launched an effort to criticize Classical Political Economy. In his indignation, the young Engels condemned the triumphant theory of Adam Smith as the hypocrisy of "beautiful speeches about a love of humanity and cosmopolitanism. «" Besides protesting, in his Outlines of the Critique of Political Economy, ${ }^{3}$ he paused in his analysis of classical economic categories, providing important embryonic formulations for Marxism.

The interpretation of the structure and operation of the capitalist economy, according to the laws, tendencies and regularities from a socio-historical standpoint, is an integral and relevant part of the elaboration and evolution of Marxist thought. The first steps in the critique of economic thought were taken by Engels. Before his meeting with Karl Marx, he wrote Outlines (I843-I844), and he published Franco-German Annals in February of 1844. Engels, although he was quite young, benefited from his experience in the family business in Manchester, the center of the English Industrial Revolution; he was

I This contribution is a translation of "A Contribuição de Engels para a Crítica da Economia Política, « in Friedrich Engels e a ciência contemporânea, eds. Muniz Ferreira, Ricardo Moreno, and Mauro Castelo Branco (Salvador: EDUFBA, 2007), 29-52. The editor of the present volume would like to thank the author and the publisher of the original work to include this translation.

2 Friedrich Engels, "Esobozo de crítica de la economia política, in Karl Marx and Friedrich Engels, Escritos econômicos vários (Barcelona: Grijalbo, 1975), 4.

3 In this text, the works Outlines of the Critique of Political Economy, The Condition of the Working Class in England, The Origin of the Family, Private Property and the State, Fundamentals of Political Economy Criticism (Grundrisse), and A Contribution to the Critique of Political Economy will be designated, respectively, as Outlines, Condition, The Origin of the Family, Grundrisse, and Contribution. 
also a witness of the Chartist movement. He was immersed in an environment in which the classical political economy of Adam Smith and David Ricardo flourished.

In the preface to $A$ Contribution to the Critique of Political Econo$m y$, Marx, when referring to Engels, speaks of »his brilliant outline of a critique of economic categories. « It should be noted that the title of Engels's article was borrowed by Marx for the subtitle of his masterwork, Capital. Outlines is quoted a few times by Marx in volume one of Capital.

Evidently, in his Outlines, Engels was in agreement with Smith in his criticism of the mercantilist system. He disputed the equating of bullion to wealth, the centrality of trade balance, and rivalry and war among nations. However, he pointed out that the first stage of trade had already been surpassed: »it was understood that our treasure, the capital that remained inactive, increased continually when in circulation. " Here we see the identification, in germinal form, of the idea of the circulation of money as capital, which results in the valorization of value. However, there is still the need, obviously, to locate the secret place where value is created, the sphere of production, and the concept of surplus-value.

Engels signaled the emergence of Political Economy as a "natural consequence of the spread of commerce. $\aleph^{6} \mathrm{He}$ understood that "the eighteenth century, the century of revolution, also revolutionized the economics. «7 All in all, Engels surpassed the evaluation of the practical conceptions of mercantilism and criticized Political Economy itself. "Modern economics - the system of free trade based on Adam Smith's Wealth of Nations - reveals itself to be that same hypocrisy, inconsistency and immorality which now confront free humanity in every sphere. ${ }^{8}$ Cyril Smith emphasized the contradiction between the previous defi-

4 Karl Marx, "Prefácio, "in Contribuiçâo para a Crítica da Economia Política (São Paulo: Nova Cultural, 1999), 53.

5 Engels, "Esobozo, «3-4.

6 Ibid., 3.

7 Engels, "Outlines, « 4I9

8 Ibid, 420. 
nition of Political Economy (according to the Outlines) ${ }^{9}$ and the other definition provided by Engels in Anti-Dühring: "Political Economy, in the broadest sense of the term, is the science of the laws that govern the production and exchange of the material means of life in human society. ${ }^{\text {IO }}$

Nonetheless, this contradiction, noted by Smith, cannot be supported. In the passage of Anti-Dühring used by Smith, Engels is using the term `Political Economy as an embryonic interpretation that reflects diverse economic forms depending on the concrete conditions of production and distribution in each place and in each historical period. He mentioned the problem of rudimentary forms of economic understanding. He referred to economy in general. Therefore, Engels was speaking hypothetically. He makes clear that "this Political Economy, conceived in these terms, with such amplitude (i.e., covering diverse human societies), is yet to be created. Everything that we have until now in terms of economic science is reduced, almost exclusively, to a genesis and to the development of the capitalist regime of production. «" Thought was restricted to Classical Political Economy, the liberalism of the writings of Adam Smith, John Ramsay McCulloch, James Mill, T. R. Malthus, J. B. Say and David Ricardo. It seems that Cyril Smith made a lot of noise for nothing.

\section{Extreme Moral Argumentation}

In the book Condition, Engels repeated the moral emphasis already present in the Outlines, asserting that the English bourgeoisie was an immoral and incurably selfish class. ${ }^{12}$ He protested that the bour-

9 Cyril Smith, "Friedrich Engels and Marx’s Critique of Political Economy," Capital \& Class 62 (1997): 127.

IO Friedrich Engels, Anti-Dühring (Rio de Janeiro: Paz e Terra, I990), I23.

II Ibid., I30.

I2 Friedrich Engels, $A$ situação da classe trabalhadora em Inglaterra (Lisboa: Presença), 364-365. 
geois individual was indifferent to the hunger of workers and was concerned only with profit. For the bourgeois, "whoever does not make money is an idiot." It was a "system of life in which each person works and enriches himself without showing concern for others. $\aleph^{13}$

This overwhelming, humanist, and moral argument reveals the limits of Engels's Outlines. The author repeatedly cited envy, avarice, covetousness, the right of the mightiest, cunning, and hypocrisy in contrast to honesty, sincerity, and reason. Mercantilism was a fraud, "the most repugnant selfishness, " while Political Economy was the "science of enrichment that springs out from the envy and avarice of the merchants. «On all these pages, we see the most outrageous indignation and moral condemnation. Already maturing, in I884, Engels, in his work The Origin of the Family, amplified the focus of temporality, proposing that "the most vulgar ambition has been the driving force of civilization from its early days to the present; its defining objective is wealth, and always wealth, but not the wealth of society but that of the petty individual. $\aleph^{\mathrm{I} 4}$

Ethical protest is essential. However, in science, it is not enough to simply replace an economic explanation with moral disapproval. The first moral protests by people like the leaders of Utopian Socialism (Saint-Simon, Fourier, and Owen) or the explosive episodes of indignation of the working masses reflected an injustice, resulting in the inequality of real economic conditions (in relation to the different social classes). It should then be recognized that »this appeal to morality and to right (law) does not make us advance scientifically even an inch. $\ll^{15}$

Moral protest, however, is inseparable both from the observation of the social and environmental ills caused as the result of the economic reproduction of capitalism and from the examination of the alternative to that state of affairs. The economic mechanism that preserves

\footnotetext{
I3 Ibid., I2O.

I4 Friedrich Engels, A origem da família, da propriedade privada e do Estado, Ioth ed. (Rio de Janeiro: Civilização Brasileira, 1985), 199-200.

I5 Engels, Anti-Dühring, I29.
} 
the interests and privileges of the ruling classes destroys the values and the sociability necessary for the ethics and the relationships among men. Instead of romanticism, naiveté, mere utopia, pious vows, and attacks against windmills, there is, besides other deficiencies, in the writings of the young Engels (in the Outlines), a complex and rich relationship between the ethical elements and the socio-economic analysis. Engels argues about the characteristics of the system of competition and private property, pointing towards classist domination while also discussing anarchy and economic crises, and the possibility of the affirmation of collective consciousness and social revolution.

We must take into account that the `modern restoration of slavery by capitalism, the horrors of colonialism, and the social consequences of the industrial revolution have accumulated a lot of material, providing many reasons for moral denunciation. Furthermore, for socialists, there can be no wall between economic development and ethics. The capitalist economic infrastructure is associated with the superstructure of prejudices, conservatism, and selfishness in bourgeois society. Gramsci drew attention to the need for a struggle in a moral and cultural direction, configuring a counter-hegemony of the workers and their allies with the aim of gaining power. In the new society, the socialist ethic consists of values like liberty, solidarity, and justice, rejecting the reductionism of the socialist transition to tasks for the development of productive forces. This ethic demands responsibility in the use of material resources; preserving the environment better, it demands democracy and the participation of the masses.

In I882, Engels, in the preface to the German edition of Condition, clarified that the context in which he made his first theoretical incursions was marked by a "juvenile stage of capitalist exploitation" in England. ${ }^{16}$ Thus, he correlates this fury of limitless exploitation with the beginnings of big industry. For this reason, at this point, in 1892 , he believed that that stage had been surpassed in England

I6 Friedrich Engels, "Introdução, "in A situação da classe trabalhadora em Inglaterra (Lisboa: Presença), 432. 
while capitalism advanced in France, Germany, and, especially, in the United States.

Engels explained that on the new English economic stage, cunning and small thefts against the workers no longer made sense, considering the progress of big industry and the broader markets. ${ }^{17}$ Big companies found the need for a certain commercial morality and to concentrate their time and attention on more relevant aspects of their business. Only small manufacturers still went for the pennies, the petty tricks, in order to survive. Social reforms, like the end of the struck system, and the law of ten hours, were "measures that challenged the spirit of free trade and unrestrained competition, but, at the same time, they increased the superiority of the colossal capitalists even more. ${ }^{18}$ The need for the presence of a large number of workers in the major companies led the bigger industrialists to prevent useless conflicts and to accept the operation of labor unions. All this was in conformity with the acceleration of the concentration of capital and the suppression of minor competitors.

For this reason, Engels modified his previous explanation of exploitation caused by immoral human behavior.

Thus,

... we should not seek the cause of this misery of the working class in these secondary effects but rather in the entire capitalist system. The worker sells his labor to the capitalist for a daily sum. After a few hours of work, he has reproduced the value of that sum, but his work contract demands that he continue working for a certain number of hours to finish the working day. At this point, the value he produces during these extra hours constitutes surplus-value, which costs nothing to the capitalist, but which he keeps in his pocket. This is the basis of the system, which increasingly divides civilized society: on the one hand, the likes of Rothschild and Vanderbilt_- owners of all the

I7 Ibid., 428.

I8 Ibid., 430. 
means of production and subsistence, and on the other, an enormous mass of salaried workers, who only have their labor. ${ }^{19}$

In juvenile capitalism, the worst abuses of the process of industrialization are found in peripheral countries like Brazil, as demonstrated in the tragic inequality of the distribution of income and the miserable living conditions of the huge working masses. In countries of this type, moreover, during this neoliberal era, new difficulties emerge, once again stressing the importance of extracting absolute surplus value. This resulted in making work more precarious, with partial hours and temporary contracts, outsourcing, hourly wages, the revocation of labor rights, pseudo-cooperatives of work, precarious systems of production engaging all the members of the family, etc.

\section{Highlighting Economic Contradictions}

Engels proposed a critique of Political Economy, declaring that he had turned to the study of the fundamental categories of classical theory, showing its contradictions and consequences. ${ }^{20}$ He noted that Political Economy's operation of interpreting the system with the isolation and individualization of interests, reducing "everything to a web of particular interests, only results in opening the way for a great transformation in which our century is going, which will lead humanity to reconcile with nature and with itself. $^{21}$

Why did Engels say that "the defenders of freedom of trade (that is, the classic economists) are worse monopolists than the old mercantilists? «"22 Why did liberalism hide the basic, sacrosanct monopoly represented by bourgeois private property? The existence of private property for a few and the misery of the English people excluded any

\footnotetext{
I9 Ibid., 430-43I.

20 Engels, „Esobozo, « 6.

2 I Ibid., 8.

22 Ibid., 5 .
} 
sense of coherence expressed in national wealth. However, focusing his attention on commerce, a consequence of private property, Engels erroneously saw the exchange of goods as "a direct source of profit, « since it is about "selling a higher price and buying as cheaply as possible."

In the controversy over value, Engels failed to understand the determination of value by the cost of production, in the sense of the quantity of labor incorporated into it, as Ricardo proposed. ${ }^{23}$ Engels saw this as "absurd abstractions." Correctly, he criticized Jean B. Say, who defined value only by the perception of the usefulness of the good, showing the subjectivity of this type of evaluation. Engels, then, proposed a kind of conciliation, asserting that "value is the relationship between cost of production and usefulness. "However, this could only be an approximation for a conventional definition of the market price.

It was only much later that Marx clarified the distinction between value, price of production, and market price. According to the distinction of the organic composition of capital, among companies, values would be transformed into prices of production, equalizing the rate of profit in different sectors within the field of competition. There would be a redistribution of surplus-value among companies through the difference between price and value, but the total value, the total surplus value, and its conformity with labor time would be maintained. Thus, the theory of value-labor was innovated and maintained. On this theme, Engels, looking at arguments about value, presented a complement to the third volume of The Capital, in which he addressed the relationship between the law of value and the rate of profit, defending the solution given by Marx for the transformation of values into production costs (in view of the criticism and confusion). ${ }^{24}$

In his Outlines, Engels perceives the contradiction present in the theory of distribution of goods. Income would be composed of the

23 Ibid., 8-IO.

24 Friedrich Engels, "La ley del valor e la quota de ganancia, in Karl Marx and Friedrich Engels, Escritos econômicos vários (Barcelona: Grijalbo, 1975), 232-248. 
remunerations of the so-called land, capital and labor services. However, "capital and labor are the same thing since [classic] economists themselves have confessed that capital is raccumulated labor « ${ }^{25}$. The separation of labor and capital, born from private property, is an expression of "the division of mankind into capitalists and workers-a division which daily becomes ever more acute, and which, as we shall see, is bound to deepen. $\ll^{26}$

Outlines presents an approach to the relationship between science and value that would later be developed by Marx in Grundrisse. Engels identified the negligence of Classic Economics with regard to the specific contribution of science towards the increase of goods: "the progress of science does not enter into its calculations. ${ }^{27}$ He shows the emergence of mechanical inventions in England to be a reaction, among other things, to the lack of workers. ${ }^{28}$ The effect of the introduction of machines was the reduction, relatively speaking, of the demand for labor. A part of the workers became unemployed while the other part saw their salaries reduced. Under these circumstances, the bargaining power of the collective actions of the workers became less effective.

Engels, in his Outlines, agrees with the Classic Economic argument that machines reduced the prices of goods, broadening the markets and resulting in new positions for the unemployed. However, he disputes the magnitude of these benefits. Let us remember the perennially large number of unemployed, the constant technological change, the division of labor that limited the worker to one specific activity in the function of the type of machine, and the difficulty for the worker to change to a new occupation.

25 Engels, "Esobozo, « II-I4.

26 Engels, »Outlines, « 430.

27 Ibid., II, 24.

28 Engels, at this point, did not yet understand the distinction between labor and a special merchandise workforce, later clarified by Marx. In I89I, Engels wrote the preface to Wage Labour and Capital, which was a work written by Marx and published in 1849 . In this preface, Engels provides a detailed explanation on the difference between concepts of labor and the workforce. 
In volume three of The Capital, Engels presents an addendum explaining that the increase in productivity consists of the decrease of live work and the increase of dead work, resulting in the reduction of the total sum of work in the commodity. He notes that this tendency to seek an increase in the productivity of labor is of no interest to capital in any circumstance. It matters »only when one saves more on the paid part of live work, than it is augmented in past work. ${ }^{29}$ However, he exaggerated the contradictions and the limits of the system, as is evidenced by technological progress in the contemporary capitalism. Engels concluded that the capitalist mode of production requires an increase in productivity, but in certain circumstances it contradicts itself, showing its senility, curbing that development of productivity.

It is obvious that Marx emphasized the centrality of the contradiction between the relations of production and the development of productive forces. This contradiction was essential for overcoming the capitalist mode of production. However, in Grundrisse, Marx presents the contradiction in a manner in which, implicitly, technological progress is not restrained:

The purpose of this production is, and continues to be, the magnitude of immediate working time .... To the extent, however, that big industry develops, the creation of effective wealth becomes less dependent on working time ... than on the power of agents [from science and technology] set in motion ... power that in turn ... has no relationship with the immediate working time that its production costs, depending more on the general state of science and the progress of technology .... Capital itself is a contradiction in progress [due to the fact] that it tends to reduce working time to a minimum, but on the other hand it puts working time as the only measure and source of wealth .... On the one hand, it awakens to life all the powers of science and nature, as well as social cooperation and exchange, in

29 Karl Marx, O Capital: Crítica da Economia Política, book 3, vol. IV.I, $3^{\text {rd }}$ ed. (São Paulo: Nova Cultural, 1988), I86-188. 
order to make the creation of wealth (relatively) independent of the working time employed in it. On the other hand, it proposes to measure these gigantic social forces created in this way in working time and reduce them to the required limits in order that the value already created is maintained as value. ${ }^{30}$

Engels implicitly placed competition as the main moment of economic activity, instead of production, just as Marx would formulate later. Engels did not yet understand that production, distribution, circulation, and consumption were indispensable, interlinked, and reciprocal conditioning moments within the same process. If, however, the Classical Economist classified the system through the beautification of free competition, contrary to the monopolies prevalent under mercantilism, then Engels's attraction to the study of competition and the market was only natural. The defense of free competition and the market by Smith is now retaken by neoliberalism, exalting the advantages of the market as the only regulating principle of the economy.

In Outlines, it is made clear that the consumer does not have perfect information about the goods offered in the market, as the Neoclassical Economy still assumes today. In spite of the veil of the freedom of the market, hiding the defects of the system, Engels genially anticipates the tendency of free competition to transform itself into a monopoly. In spite of liberal preaching, competition, based on interests that aspire to domination, "always ends in monopoly." Our author continues by clarifying that this does not mean the end of competition among companies since "a monopoly cannot contain the flow of competition. « ${ }^{\text {I }}$

The tendency to centralization and the concentration of capital was further developed by Marx in Capital. That law of movement

30 Karl Marx, Elementos fundamentales para la crítica de la economia politica (Grundrisse) $1857-1858$, vol. 2. I3th ed. (México: Siglo Veintiuno, 1997), 227-229. My emphasis.

3I Engels, »Esobozo, « I5, 23. 
originated from accumulation and competition, which are coercively inevitable. It stemmed from the possibilities opened by the credit system, from the role of limited liability companies, exemplified by the masses of capital of the English railroads. It stemmed from the need to increase the organic composition of capital due to the indispensable technological progress.

The capitalist dynamic, based on instability and imbalance, is marked by periodic crises, occurring "with the same regularity as that of comets, ${ }^{32}$ remarks Engels. Instead of information, calculation and planning, the economy is afflicted by the "lack of conscience of the interested parties." This is what the natural law of economic equilibrium comes down to, in spite of the illusions of Political Economy. Whereas Classical Economists emphasized the harmonious nature of the economy and individual interests, Engels argued for the necessity for a collective conscience and the actions of men, not of loose atoms. This argument about collective human will had nothing to do with the positivism that, with some simplifications, some tried to accuse Engels, as we can see:

What can we think of a law that can only be imposed through periodic revolutions? That it is precisely a natural law, based on the lack of conscience of the interested parties. If producers as such knew how much the consumers needed, if they could organize production and distribution, it would be impossible for there to be fluctuations in the competition [market] and their tendency towards crises. It produces in a conscious manner, and it overrides all those artificial and unsustainable contradictions. However, as long as it continues to produce, as it does now in an unconscious manner, there will continue to be commercial [economic] crises, and each one of them will be necessarily more universal and, consequently, more devastating than the previous ones. It will ruin a greater number of small capitalists, and it will increase, in greater proportions each time, the class of those who

32 Ibid., I6. 
live off their work. In other words, it will increase the mass of labor that requires occupation, which is the fundamental problem of our economists, until finally a social revolution that our economists are incapable of imagining is provoked..$^{33}$

In spite of its limitations, Outlines has a general view in which private property and competition are unmasked as the fundamentals of Classical Political Economy. In the work Condition, Engels reaffirms the appearance of periodic crises when the internal and external markets become filled with English products. ${ }^{34}$ This is a description of a certain regularity of the cycles of overproduction. It is an open challenge to Smith's self-regulation of the market and Say's law of markets, supported by Ricardo, in which production creates its own demand, without the possibility of a crisis.

According to Engels, the concept of anarchy in the system covers both the productive effort and the distribution of consumer goods. ${ }^{35}$ This anarchy is linked to the object of profit instead of the satisfaction of social needs. He concluded that this anarchic operation of the economy is what imposed the disturbances and crises. Malthus theory of population, ${ }^{36}$ justifying the "contradiction between simultaneous wealth and misery, « demanded a response. On the one hand, Engels, with a certain "productivist « charge, ${ }^{37}$ responded that, in the case of agriculture, »in a conscious manner and in the interest of ev-

33 Ibid., 16.

34 Engels, Classe trabalhadora, I2O.

35 Ibid.

36 "Population, when not controlled, increases in a geometric progression. The means of subsistence only grow in an arithmetic proportion [...]. Without doubt it is disheartening to think that the great obstacle on the road to any perfecting of society is of such a nature that we cannot hope to ever overcome it. The permanent tendency of the human species is to grow beyond the means of subsistence, and one of the general laws of nature is that we do not have any reason to think that it will change." Thomas Robert Malthus, Ensaio sobre a população (São Paulo: Nova Cultural, 1996), 246, 360-36r.

37 This productivism, contrasting with ecological concerns, is immediately relativized when Engels explains that this unlimited capacity, consciously conducted, 
eryone, " "the investment of capital, labor and science could potentialize the capacity of production of the soil infinitely. ॥ $^{38}$ On the other hand, referring to the general conditions of the market, he stated that "population is only excessive where the capacity of production is excessive." The unemployed workforce is only an excessive capacity under certain economic circumstances. Engels, despite the emphasis on competition, does not shy away from reasoning about production fluctuations. He reasons that there is a type of equilibrium in which the productive impulse is weak, in which unemployment and hunger are inevitable. If production accelerates, then we are open to the possibility of creating a future situation of super-production or even stagnation.

English industry needed a "reserve of unemployed workers. (39 $^{39}$ That reserve was permanent except during "short periods of greater prosperity." The magnitude of this reserve varies according to the behavior of the market, with greater or lesser occupation. A company's search for an increase in the productivity of each worker is associated with the problem of unemployment. Thus, "the productivity of each worker raised to its maximum by competition, the division of labor, the introduction of machinery, and the utilization of natural forces are factors that lead to the unemployment of a multiplicity of workers. ${ }^{40}$ This formulation about the reserve of unemployed workers would later be developed by Marx as the concept of the "industrial reserve army."

In contrast to the use of overpopulation to explain misery (and unemployment), in Malthus` proposition, Neoclassical Economics has enthroned, since the last decades of the nineteenth century, the balance of the labor market, with the economy naturally functioning at full employment and without crises. Only later, during the Great Depression, did John M. Keynes present a formulation of the

would reduce "the burden of work that weighs upon humanity, i i. e. upon the workers.

38 Engels, "Esobozo, " I8.

39 Engels, Classe trabalhadora, I23.

40 Ibid., II9. 
possibility that the economy would fall back and prostrate itself in a form of equilibrium with unemployment. Thus, Keynes broke with Neoclassicism and recognized the existence of involuntary unemployment. This conclusion could, in a certain way, be associated with Engels's intuition linking unemployment with the effects of the rate of growth of production. ${ }^{4 \mathrm{I}}$

\section{Popularization of Economic Theory}

Engels denounced the emergence of an abstract materialism, distant from concrete contradictions, in the explanation of the contempt and humiliation of men, that is, the "suffering of Christians. «2 $^{42}$ God was exchanged for nature as something absolute, inevitable, for the effects of the economy upon the fate of men. Thus, Political Economy, instead of bringing forth a revolutionary examination of economic contradictions, preferred to adapt itself to the coming bourgeois era. For this reason, Classical Economists only represent intermediate progress with regard to the mercantilists.

Throughout the history of capitalism, there is a conventional theory, with various versions, that attempts to naturalize the economy. It sounds like an interdiction against any political intervention that is contrary to bourgeois interests. Engels exposes classical theory as an effort to beautify the economy through the exaltation of gains for the consumers (which today is called the "principle of consumer sovereignty «) and the celebration of the market as a bond of harmony between nations and individuals.

4I In Keynes` thought, there is a reference to the analysis of Malthus (see Principles of Political Economy, Chapter VII), one of the representatives of Political Economy, who was alone in his argument about the possibility of the general saturation of merchandise and the insufficiency of demand, which contrasted with the statement of Say's law that prevails in Classical Economics.

42 Engels, »Esobozo, « 4. 
On the distinction between scientific Political Economy and vulgar Economics, Marx stated:

And to clarify once and for all, I understand as Classical Political Economics all economics since William Petty, which investigates the internal nexus of the bourgeois conditions of production as the antithesis of vulgar economics (which only moves within the apparent nexus), ruminating again on the material already provided by scientific economics, offering a plausible understanding of phenomena that are coarser and for the domestic use of the bourgeoisie, and is limited, moreover, to systematizing, pedantizing, and proclaiming as eternal truths the banal and presumptuous ideas that the agents of bourgeois production create around the world, which for them are the best possible. ${ }^{43}$

Political Economy only had a scientific character until David Ricardo, according to the judgment of Marx. ${ }^{44}$ Thus, the economy started to have a vulgar character from I830, when the class struggle began to manifest itself with more clarity. Economic categories started to be presented directly, wrapped in the veil of ideological contraband of the class interests of the bourgeoisie.

The author of Outlines presents similar reasoning to Marx's classification of vulgar Economics, but attacking, in some ways, even Ricardo himself: „While Smith and Malthus only met with loose fragments, later economists already had the whole system finished before them; all the consequences were in plain view, the contradictions were evident. «45 There was a course of vulgarization, that is, a growing bourgeois ideologization of Political Economy. Ricardo was blamed for the scientific regression more than Smith, while Stuart

43 Karl Marx, O Capital: Crítica da Economia Política, book I, vol. I.I (São Paulo: Abril Cultural, 1988), 76, n. 32.

44 Karl Marx, "Posfácio da segunda edição, " in O Capital: Crítica da Economia Política, book I, vol. I.I (São Paulo: Abril Cultural, I988), 22-23.

45 Engels, »Esobozo, « 5 . 
Mill had contributed more to the misrepresentation of economics than Ricardo.

In epistemological terms, Engels's intuition has great importance. It shows an escalation of superficiality or incessant reductionism, which accompany the unfolding of the dominant economic thought. And this is confirmed more and more, over time. In Political Economy, the attempt to naturalize economic facts, detaching them from the social and historical context, was repelled by Marx and Engels. Based on materialist conception of history, it was not possible to understand the capitalist system itself as something natural, eternal, the end of the evolution of humanity.

From the time of the founders of Marxism until today, things have only worsened in the field of the dominant economic theory. As we know, the accumulation of capital in our times has come to be understood as a gift of nature according to the automatism of the market, so long as each individual is not cut off from his activity, his entrepreneurship, and his self-interest by government interventionism, and »syndicalist monopolies". Therefore, let us look, briefly, at this growing abstraction of economic theory in the face of the prevailing socio-economic reality in the capitalist system. The Neoclassical school, which emerged in the I870s (particularly with Leon Walras, William Stanley Jevons, and Carl Menger), abandoned the focus of Political Economy on the determination of value based on labor. It covered up the investigation of problems regarding the distribution of goods among the social classes, putting aside Ricardo's concerns. They simplified the difficulties of effective demand, in spite of Malthus early warnings. Even the general equilibrium of Walras and the quantitative theory of money sanctioned reductionist visions of the general problems of production and circulation in the economy.

From Classical theory, the Neoclassical authors broadened and radicalized the concepts of the naturalization, harmony, and equilibrium of the economy. In the Neoclassical context, the marginalist analysis appears as an expression of the premises of rationality and the maximizing behavior of homo economicus. Thus, the preferences of 
the consumer enthrone the deciding role, resulting from the individual's choice in driving the economy. As a microeconomics of pricing, the theory was actually reduced to quantitativist formalism in order to simply describe the operation of the markets. The self-regulation of markets would promote economic stability.

The history of the vulgarization of economic thinking according to dominant ideas has been a long one. Keynesian thought, partially divergent from this decadence, identified involuntary unemployment and economic malfunctions, but this generated the illusion that government action would be capable of preventing the crises of capitalism. From the r970s onwards, there has been an upsurge in the vulgarization of economics with the monetarism of Milton Friedman and, later, the so-called school of rational expectations of Robert Lucas. The latter would represent the so-called ınew classics, $<$ as if it was a radicalized and worsened return to Classical Economics. There is a return to the aversion to any governmental intervention, assuming unlimited rationality on the part of individuals and sanctifying the self-regulation of the markets.

\section{History and Economics}

In the preface to Origin, Engels attests that the materialist analysis of history is Marx's and, he adds, "to a certain extent, our." In the epistemology of classical Marxism, an association predominates between the economic explanation and the theory of historical materialism. ${ }^{46}$ The economy is a decisive, though not exclusive, factor in the evolution of society. For this reason, Engels considered that an increase in productivity was the key to understanding the evolution of private property, exchange, and the use of others labor, resulting in contradictions among the recently constituted social classes. ${ }^{47}$ Over

46 Jacob Gorender, "Introdução, "in Karl Marx, Para a crítica da economia política: Salário, preço e lucro (São Paulo: Abril Cultural, 1982), vii.

47 Engels, $A$ origem da família, 3. 
time, moving from adaptation to incompatibility between the new conditions and the old structure, there emerged, after a long time, the superseding of a society based on ties of kinship by a society organized around the power of the State and relationships of property.

In civilization, slavery took deep roots, and society was divided between an exploiting class and a class of the exploited. ${ }^{8}{ }^{8}$ Over the course of time, the development of civilization always manifests the contradiction between the progress of production and the conditions of the oppressed class. ${ }^{49}$ In civilization, there is a march towards the exacerbation of the division between labor and mercantile production. ${ }^{5 \circ}$

In the evolution of capitalism, there was a period of so-called 'primitive accumulation between the sixteenth and seventeenth centuries. From the eighteenth and nineteenth centuries on, in England, there has been capitalism with its own technology, with big industry and the actual subsuming of labor to capital. Maurice Dobb records that Engels was one of the first to use the term Industrial Revolution to describe the transformations in the English economy and society. ${ }^{5 \mathrm{I}}$ Engels compared the importance of the Industrial Revolution, which had the creation of the proletariat as its main result, to the magnitude of the French Revolution. In the introduction to Condition, Engels asserted that the Industrial Revolution in England "transformed bourgeois society in its totality. "s2 $^{52}$

In order to study the proletariat, Engels did fieldwork, as he explains in the preface to Condition: "I lived for a long time among you [the workers], and for this reason I am well informed about your living conditions. ${ }^{53}$ This accelerated industrialization demanded the emigration of »compact masses of workers" from the countryside and

\footnotetext{
48 Ibid., 198.

49 Ibid., 200.

50 Ibid., 196.

5I Maurice Dobb, A evolução do capitalismo, 6th ed. (Rio de Janeiro: Zahar, 1977), 3I6, n. 3 .

52 Friedrich Engels, "Prefácio: Aos trabalhadores ingleses, " in A situação da classe trabalhadora em Inglaterra (Lisboa: Presença), I5.

53 Ibid., 7.
} 
provoked a rapid demographic growth. ${ }^{54}$ Artisans were ruined, and workers lost "the last vestiges of independent activity, " resulting in the blocking of mobility for the middle social strata. 5 This situation forces us to think, to become aware, and opens up, for the first time, the possibility for the proletariat to begin an independent movement, concludes our author.

Concerning the State in general, Engels presents two fundamental traits: first, the State is a cohesive force of civilized society; and second, the State, always, in all typical periods, is an exclusive institution of the dominant class and consists, essentially, of an instrument of repression against the oppressed and exploited class. ${ }^{56}$ Therefore, in the State, there is, simultaneously, a duplicity of cohesion and repression. Despite the classist character of the State, in the case of capitalism, the bourgeoisie has some reservations about the role of the State in certain matters that may contradict their economic interests. The bourgeoisie uses the State against the proletariat, but it keeps the State, according to their ability and convenience, distant from certain issues related to economic activity. ${ }^{57}$

After the crisis of 1847, Engels identified the emergence of a new industrial era. ${ }^{8}$ The liberalization of foreign trade emerged with the repeal of the grain law, the expansion of colonial markets, the opening of China, the conclusion of the ruin of millions of weavers in India as a result of the competition from mechanical weaving in England, and the accelerated economic transformation of the United States.

In Condition, Engels predicted, in 1844, the overcoming, within twenty years, of English industry by competition and the subsequent spread of unemployment to the majority of the proletariat, ${ }^{59}$ who

\footnotetext{
54 Engels, "Introdução, « 33.

55 Ibid., I8, 34 .

56 Engels, $A$ origem da família, 196.

57 Engels, Classe trabalhadora, 366.

58 Friedrich Engels, "Prefácio à edição inglesa em 1892, "in A situação da classe trabalhadora em Inglaterra (Lisboa: Presença), 428-429.

59 Engels, Classe trabalhadora, 387-388.
} 
would be left with no alternative but "to die of hunger or start a revolution. " ${ }^{60}$ In 1892, Engels recorded, as a confirmation of this forecast, the rupture of the English industrial monopoly, setting a watershed that would lead the English proletariat to the loss of its privileges and free itself from the influence of its workers aristocracy and turn towards the cause of socialism. ${ }^{61}$

Towards the end of the nineteenth century and at the beginning of the twentieth century, new circumstances emerged through financial capital, monopolies, and the end of the partition of overseas colonies by the great powers. Capitalism had entered its imperial stage, as evidenced by the development of Marxist theory through Rudolf Hilferding, Rosa Luxemburg, Nikolai Bukharin, and Vladimir Lenin.

This new era of financial domination did not escape the notice of Engels. ${ }^{62}$ Thus, in the last year of his life, 1885 , he wrote a note, later incorporated in Capital, analyzing the role of the stock market in the capitalist system. Engels noted the great changes in the significance of the stock exchange since Marx had written the third volume of Capital. The stock market had become "the most important representative of capitalist production." Along with the acceleration of accumulation, the group of rentiers was growing and new forms of associations were emerging in order to facilitate the investment of great amounts of capital. These new circumstances favored the emergence of trusts of production in commerce, banks, and lending institutions. Agriculture, foreign investments, and colonization companies would also become linked to the stock market.

60 "It is not right to suppress in the text numerous prophecies, in particular the one about an imminent social revolution in England, which were inspired by my juvenile ardor. What is surprising is not that many of those predictions did not come about but that many others were just and that in the critical period of English industry - consequence of the continental competition, mainly American-have effectively arrived." Ibid., 434.

6I Engels, "Prefácio à edição inglesa, " 432. Also see Dobb, Capitalismo, 366.

62 Friedrich Engels, »La bolsa, " in Karl Marx and Friedrich Engels, Escritos econômicos vários (Barcelona: Grijalbo, 1975), 248-249. 


\section{Engels's Place in his Collaboration with Marx on Economics}

There is some controversy around the legacy of Engels, including in his critique of Political Economy. Some find that Engels promoted a revision of Marx's theory, turning towards a sort of reductionism or determinism. It is not the purpose of this article to deal exhaustively with this problem, but it is important to address his synthesis. J. D. Hunley points out that, since the I960s, there has been an increase in questions about the compatibility between Marx and Engels. ${ }^{63}$ Hunley adds that the prevailing view today is that there are important differences between the two German revolutionaries. Eduard Bernstein (in the I890s), Rodolfo Mondolfo (I9I2), George Lichtheim (I96I), Norman Levine (1975), Terrell Carver (I883), and others are some of the so-called dichotomists since they have refuted, in different measures, the intellectual affinity between Marx and Engels.

Levine claims that there are important discrepancies between the first section of Engels's edition of Volume 2 of Capital and the manuscripts kept in the International Institute of Social History. Among other things, this would result in the substitution of the Hegelian understanding of the totality of the economic process with Marx's on the empiricist emphasis on particularity on the part of Engels. ${ }^{64}$ However, among the various materials left by Marx, we can see both possibilities (totality and particularity), thus revealing some ambiguity, according to Hunley. Jerrold Seigel recognizes that there are discrepancies between the manuscript and the edited text of Volume 3, but, in contrast to Levine, he sees the modifications introduced by Engels as necessary and justified. In his view, Engels rearranged some sections of chapters 13 and 14 of Volume 3 and attributed a more important role to neutralizing forces of the law of the decreasing tenden-

63 J. D. Hunley, "The Intellectual Compatibility of Marx and Engels, «Social Theory \& Practice I7, no. I (I99I): I.

64 Ibid., 8. 
cy of the rate of profit. That solution by Engels reduced the positivism of the text, according to the law mentioned above. ${ }^{65}$

Hunley concluded that the two friends were in agreement on the fundamental issues. The great proof of unity was the harmonious work that they did together for almost 40 years, which included books and numerous journal articles. ${ }^{66}$ It was Engels who suggested the title and the opening sentences of The Eighteenth Brumaire of Louis Napoleon. Engels also provided valuable insights into the mode of Asian production that were taken up by Marx.

In view of the strong accusation of vulgar economic determinism imputed on Marx and, above all, Engels, it is crucial to mention the letter that the latter sent to Bloch on September 2I, I890:

According to the materialist conception of history, the factor that ultimately determines history is the production and reproduction of real life. Neither Marx nor I stated anything more than this. If someone modifies the thesis saying that economic facts are the only determinant facts, then he would be making the thesis empty, abstract, and absurd. The economic situation is the basis, but the different factors of the superstructure that is built upon it - the political forms of the class struggle, the constitutions that, once a battle is won, the triumphant class writes, etc., the judicial forms, and even the reflections of all these real struggles in the brains of those who participate in them, the political, juridical and philosophical theories, the religious ideas and the further development that leads them to become a system of dogmas-also exert influence upon the course of historical struggles and, in many cases, determine their shape, as the predominant factor. It is a reciprocal game of actions and reactions among these factors, in which, through an infinite number of cases (that is, things and events whose internal connection is so remote or so difficult to demonstrate that we can consider it non-existent), the

65 Ibid.

66 Ibid., I7-I8. 
economic movement always imposes itself as a necessity. If that was not the case, applying the theory to any historical epoch would be easier than solving a first-degree equation. ${ }^{67}$

Cyril Smith claims that Engels did not understand Marx's attitude with regard to Political Economy. ${ }^{68}$ For this critic, Engels would have gradually distanced himself from his valuable discoveries recorded in Outlines, abandoning the ethical and human vision, neglecting the monopolistic meaning of bourgeois private property. One of the important findings of Outlines, the verification that the old mercantile system had "a certain open, catholic frankness, " did not indulge in theoretical economic competitions in order to cover up all its commercial immoralities. ${ }^{69}$ It changed reality and economic discourse. In Outlines, it was identified that in the new global conditions, now more humanized and attaching greater importance to value and morality, there was a place for Classical Economic theory in the form of Adam Smith. In Outlines, the pioneering perception of the links between economics and religion, within the framework of Protestantism, made Engels admire Adam Smith as an economic Lutheran, according to Cyril Smith.

Adam Smith showed the human aspect of commerce (that is, economic liberalism): without wars among nations, without deliberate economic privileges by the State, without repression of the freedom to decide by each economic agent, without the prohibition of the will of the consumer in the act of exchange. This humanism, however, was very partial. All of this, in essence, was a "way to abuse morality for immoral goals. $\aleph^{70}$ In fact, private property prevailed as a monopoly, free competition to defraud consumers, civilization as exploitation

67 Friedrich Engels, "Carta de Engels a Bloch, em 21 de setembro de I890, "in Karl Marx and Friedrich Engels, Obras Escolhidas, vol. 3 (Sáo Paulo: Alfa-ômega), $284-285$.

68 Smith, "Engels and Marx, «I23-I42.

69 Engels, »Esobozo, 7 .

70 Ibid. 
of the people in the colonies, free-for-all competition, antagonism between collective and individual interests.

Cyril Smith believes that Engels would have departed from the criticism of the categories of Political Economy, namely: use value and exchange value, value and price, labor, profit, and income. Engels would have underestimated the dual character of labour, the forms of value and fetishism. ${ }^{71}$ In contrast, Engels would have focused, over time, unilaterally on the concept of surplus-value, would have turned to the appreciation of value, emphasizing merely quantitative aspects. He would have become entangled in the question of materialist dialectics. He did not value his own critique of the population theory of Malthus in the terms that had already been established in Outlines. He did not go back to the universal human base employed to criticize both mercantilism and Political Economy. ${ }^{72}$

According to Cyril Smith, Marx's critique of Political Economy did not turn to an empirical, factual description of the operation of capitalism nor to the proposition of the economic elements of socialism. ${ }^{73}$ The word 'capitalism does not appear in Capital. The Marxist critique would have turned to the ideas and interpretations of the classics concerning the social relationships engendered by capital and its consequent contradictions. Cyril Smith thinks that criticism, for Marx, had the priority of challenging, in theory, in categories, in the most advanced and coherent system of economic thought, that is to say, Political Economy (since it explains the nature of modern society)..$^{74}$ The inhumanity of bourgeois relationships was theorized as something natural and eternal by Political Economy.

For Marx, the point of departure of the critique of Political Economy had to be human society, social humanism, in the view of Cyril Smith. ${ }^{75}$ Instead of capitalism, Marx spoke of capital as a social rela-

\footnotetext{
7I Smith, "Engels and Marx, « I36.

72 Ibid., $126-128$.

73 Ibid., I24-I25.

74 Ibid., I24-I26.

75 Ibid., I25.
} 
tionship, hidden by the fetishism of merchandise. Value, for Marx, surpassed quantification and expressed human relationships as if they were relationships among things (20 yards of linen = one coat).

In the face of these criticisms by Cyril Smith, it is worth asking: is it true that, for Engels, the understanding of economics and classical thought was different? Let us see what he says: "The economy is not about things but rather relationships among people, and, ultimately, between classes, although these relationships are always linked to things and they look like things. ¿ $^{76}$

The facts made it difficult for Engels to accept the accusation of falsifying Marx's thought. In the end, there were almost 40 years of intellectual collaboration between the two of them, with many texts written with the input of both. Furthermore, it is important to take into consideration all the revolutionary activity, in political affinity, that defined the lives of these friends. It is significant that after the death of Marx, the great political authority of the socialist movement was Engels, and even after his own death, his influence extended for many years among the ranks of the Second (Social-Democratic) International. There are many reasons for calling Marx and Engels the Dioscuri, the twin heroes of Greek mythology. For Paul Lafargue and Wilhelm Liebknecht, Engels was Marx's alter ego. Marx's daughter, Eleanor, referring to their life and work, said that it was impossible to separate them. ${ }^{77}$

It is counterproductive, in theory and method, to promote a clear separation between the work of Marx and the work of Engels. ${ }^{7}$ With

76 Friedrich Engels, "A contribuição para a crítica da economia política, de Karl Marx, « in Karl Marx and Friedrich Engels, Obras Escolhidas, vol. I (São Paulo: Alfa-ômega), 3II.

77 Hunley, »Intellectual Compatibility, « I.

78 In 1844 Engels published the Outlines and wrote Condition. Referring to his ideas during this period, Engels recognized, in I892, with regard to Condition that "a book in which what is good is as much as what is bad shows the youth of the author" (427), I was twenty years-old, today I am three times older, and when I reread that book, I do not think that I need to be ashamed of it, and »it is not worth noting that the general theoretical point of view of this book-on the 
regard to economics, in the division of work between the two friends, Marx took care of the deepening and systematizing of economic theory, but Engels was the precursor for some relevant ideas. He brought forth embryonic elements that stimulated Marx's study of economics. It is also inevitable to recognize that Engels assumed responsibility for editing the last two volumes of Capital, which included the technical work of redacting and, in the case of Volume 3, he made the effort to render intelligible some materials that had been left in rough shape by Marx. In that effort, beside his explanatory notes, Engels wrote the chapter on the effect of rotation on the rate of profit. Furthermore, we cannot ignore Engels's effort to popularize Capital, breaking the so-called 'Conspiracy of Silencer through the publication of reviews and summaries in multiple forms of print.

The possibility of differences in focus and understanding between both thinkers is natural. Without a doubt, Engels always made the main role of Marx clear in the context of their collaboration. This is especially noted with regard to their economic studies. In spite of this, Engels was sought by Marx before the writing of Capital to collaborate on certain investigations, in addition to their correspondence and the debates they held on economics and literature. In this sense, we can consider the following examples: Engels's criticisms of concepts that underestimated the progress of agriculture; Engels's reception of Marx's ideas that were contrary to what is called the quantitative school of currency (currency in circulation determining prices, foreign trade and crises $^{79}$ ); the information Engels provided to Marx

philosophical, economic and political plain-does not exactly coincide with my current position. In 1844 there was no modern international socialism that the works of Marx almost exclusively made into a science. My book represents one of the phases of that embryonic movement. (433). (Preface to the English 1892 edition of The Condition of the Working Class in England).

79 The monetarism of Milton Friedman, starting in the I970's, had its origins in ideas already refuted by Marx I50 years earlier. The dynamic of the economy and the movement of prices make the circulation of currency and the credit system into derivative phenomena, although a serious mistake of a Central Bank in monetary policy can create economic problems. 
on the share of consumption by capitalists in the revenues of their companies; and the report Engels wrote, at Marx's request, about the cotton crisis of $1965 .^{80}$

The accusations that are made are either exaggerated or totally false. Thus, for example, there is no room to say that Engels influenced Marx negatively, supposedly simplifying, for the sake of popularization, the explanations in chapter I of Volume I of Capital. In fact, it was in response to Marx's letter, dated 3 June I867, that Engels, without prejudice of logical or conceptual argument, suggested the use of historical illustrations on the process of the formation of money in addition to the organization of the presentation of the text.

Engels himself explained his methodology in his preface to Contributions.$^{8 \mathrm{I}}$ For him, it was possible to employ two methods, historical and logical, in the critique of Political Economy. With regard to the historical method, he says: "This form presents, apparently, the advantage of greater clarity since in it we find the real development of things, but in practice the only thing that would result, in the best of cases, would be its popularization. ... Therefore, the only method recommended is the logical one. However, this is, in reality, nothing but the historical method, stripped only of its historical form and its disturbing contingencies. ${ }^{82}$

Even in works that do not have economics as their main theme, Marx and Engels always make references to economic problems. For example, in The German Ideology, there is a strong presence of economic elements. And so, as in their collaborative works, is it possible to locate and separate the economic contributions of Marx and Engels, and then place those contributions in opposition, one in relation to the other? This would not make sense. It is obvious that there is a

80 Instituto de Marxismo-Leninismo, PCUS. Biografia de Friedrich Engels (Lisboa: Avante, 1986), 4II-4I3.

8I Preface in 1859 , that is, I5 years after Outlines, which negates the accusation that Engels, with the passing of time, had lost his understanding of Political Economy and had distanced himself from Marxist thought in this field

82 Engels, "Contribuição," 3IO. 
sense of unity throughout their work, even though it was written by two people.

Translated by Gilmar Visoni-Alonzo

\section{Works Cited}

Dobb, Maurice. A evoluçấo do capitalismo. 6th ed. Rio de Janeiro: Zahar, 1977.

Engels, Friedrich. „Esobozo de crítica de la economia política." In Escritos econômicos vários, by Karl Marx and Friedrich Engels. Barcelona: Grijalbo, 1975 .

-. "La ley del valor e la quota de ganancia." In Karl Marx and Friedrich Engels, Escritos econômicos vários. Barcelona: Grijalbo, 1975.

—. "La bolsa.« In Karl Marx and Friedrich Engels, Escritos econômicos vários. Barcelona: Grijalbo, 1975.

-. A situação da classe trabalhadora em Inglaterra. Lisboa: Presença.

—. "Prefácio: Aos trabalhadores ingleses. "In A situação da classe trabalhadora em Inglaterra. Lisboa: Presença.

—. "Introdução." In A situação da classe trabalhadora em Inglaterra. Lisboa: Presença.

—. "Prefácio à edição inglesa em I892. "In A situação da classe trabalhadora em Inglaterra. Lisboa: Presença.

—. "A contribuição para a crítica da economia política, de Karl Marx." In Obras Escolhidas, vol. I, by Karl Marx and Friedrich Engels. São Paulo: Alfa-ômega.

—. "Carta de Engels a Bloch, em 2I de setembro de I890." In Karl Marx and Friedrich Engels, Obras Escolhidas, vol. 3. São Paulo: Alfa-ômega.

-. A origem da familia, da propriedade privada e do Estado. $\mathrm{Io}^{\text {th }} \mathrm{ed}$. Rio de Janeiro: Civilização Brasileira, 1985.

—. Anti-Dühring. Rio de Janeiro: Paz e Terra, 1990.

Gorender, Jacob. "Introdução." In Karl Marx and Friedrich Engels, Para a crítica da economia política: Salário, preço e lucro. São Paulo: Abril Cultural, 1982. 
Hunley, J. D. "The intellectual compatibility of Marx and Engels."Social Theory \& Practice 17, no. I (Spring 199I): I-22.

Instituto de Marxismo-Leninismo. PCUS. Biografia de Friedrich Engels. Lisboa: Avante, 1986.

Malthus, Thomas Robert. Ensaio sobre a população. São Paulo: Nova Cultural, I996.

Marx, Karl. Elementos fundamentales para la crítica de la economia politica (Grundrisse) 1857-1858, vol. 2. 13 ${ }^{\text {th }}$ ed. México: Siglo Veintiuno, 1997.

-. "Posfácio da segunda edição. "In O Capital: Crítica da Economia Política, book I, vol. I.r. São Paulo: Abril Cultural, I988.

-. O Capital: Crítica da Economia Politica, book I, vol. I.I. São Paulo: Abril Cultural, 1988.

-. O Capital: Crítica da Economia Politica, book 3, vol. IV.r. $3^{\text {rd }}$ ed. São Paulo: Nova Cultural, 1988.

—. »Prefácio."In Contribuição para a Crítica da Economia Política. São Paulo: Nova Cultural, I999.

Marx, Karl and Friedrich Engels. A ideologia alemã. São Paulo: Martins Fontes, 2002.

Smith, Cyril. "Friedrich Engels and Marx's critique of political economy." Capital \& Class 62 (1997): I23-I42. 


\title{
The Psychology of Friedrich Engels
}

\author{
From the Materialist Theory \\ of Manual Labor to the Critique \\ of Empiricism and Ideology ${ }^{1}$
}

David Pavón-Cuéllar

Introduction: Engels as a Marxist Psychologist

Friedrich Engels (1820-1895) was a Marxist, but only to the extent that Marx was also an Engelsian. The two men followed each other, they learned together and forged their ideas together, including those of a psychological nature. Substantive parts of the psychology that we attribute to Marx, presented and explained recently, ${ }^{2}$ are also attributable to Engels. Hence, some authors prefer to speak of the psychology of Marx and Engels. ${ }^{3}$ However, there are also original Engelsian contributions that must be considered separately, not because they contradict Marxian theory but because they preceded Marx's theory and advanced it through new avenues that paved the way for a Marxian psychology, stabilizing concepts that were still volatile in Marx.

As we shall see, it is to the young Engels that we owe some of the first psychological formulations of Marx's psychologies of material and historical determination, economic personifications, bourgeois individuality, and resistance and rebellion. We also know the original mature Engelsian theories about psychic life: about its origin in manual work,

I The present chapter is a translation of "La psicología de Friedrich Engels: de las teorías materialistas del trabajo manual y del reflejo a la crítica del empirismo y de la ideología", Dialectus 2(6) (2015): I50-I62. The editor would like to thank the author and the publisher of the original work for the possibility to include it in the present volume.

2 "Las dieciocho psicologías de Karl Marx, "Teoría y Crítica de la Psicología 5 (2015): IO5-I32.

3 See Samuel P. Coe, Contemporary Psychology in Marx and Engels (New York: American Institute for Marxist Studies, 1978). 
its constitution as a reflection of the real, its mediating function between subject and mundane-corporeal reality, and its immaterial figuration as a primitive form of understanding dream phenomena. Engels offers us an interesting theoretical-methodological critique of empiricist materialism in his elucidation of the psyche, as well as a denunciation of the psychological operation in the essence of ideology and the expansion of the horizon of the psychological-materialist explanation, beyond the productive, social basis and towards the foundations of sexual reproduction.

Considering the importance of the articulations of Marxism and psychoanalysis in the various intellectual movements of the last 150 years, we will pay close attention to co-incidences between the Engelsian and Freudian perspectives. We will see Engels agree with Freud in his emphasis on sexuality and family, as well as in the valorization of symptoms, the problematization of individuality, the consideration of corporeal materiality (and not only the mundane form), and the redirection of the abstract dualism of soul-body to the concrete monism of the body, and even the demonstration of psychic determination through hypnotic suggestion. With regard to the commonalities with Marx, we will also see how they are permanent and tend to systematize into a unitary theory, which will justify our assertion that Engels's is the first of the Marxist psychologies. However, this does not exclude the existence of a critical tension between the psychological discipline and Engels's perspective.

\section{The Soul of the English Workers: The First Materialist Psychology}

In his early work The Condition of the Working Class in England, ${ }^{4}$ Engels presents some psychological reflections that Marx later develops. The psychology of material determination was already delineated in

4 Friedrich Engels, La situación de la clase obrera en Inglaterra (Moscow: Progreso, I980 [I845]). 
his dialectical characterization of the workers, who were both harmed by as well as beneficiaries of economic exploitation: deprived of »intellectual activity" and "degraded " to "the condition of beasts, « they were nonetheless favored with "completely developed feelings" and "strong passions" thanks, precisely, to their lack of bourgeois »intellectual culture" that "makes selfishness the main passion" and "concentrates all strength on money. " ${ }^{5}$ In terms of economic personification, the bourgeois man is a "money-man " who only seeks "accumulation," whereas the worker is "more social « and his eyes are open more widely since he does not relate to the world with selfishness and prejudices,

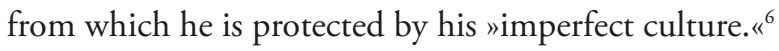

In the Engelsian psychology of the English workers, as well as in the later perspectives of Marx and Freud, ${ }^{7}$ the cultural disadvantage implies, dialectically, a vital advantage. The workers' lack of culture allows them to develop their sociability, knowledge, passions and feelings. Their fortune lies in their misery. Analogously, the misery of the bourgeois individual is rooted in his wealth, which isolates him in his prejudiced and selfish individuality.

Anticipating the theory of mass society, Engels transforms the psyche of bourgeois individuality into the hegemonic model of modern cities that promotes "sordid egotism, " the "isolation of each individual in his private interests, " and the fragmentation of society into "atoms" or "monads. $\aleph^{8}$ The "great cities" would discover the "disease of the social body, « and this was positive for Engels and his revalorization of the symptom because this enabled him to learn the "appropriate means to heal it. « ${ }^{9}$ This same Engelsian dialectic, a precursor of the Freudian principle of abstinence and of the Marxian psychology

\footnotetext{
$5 \quad$ Ibid., 89.

6 Ibid., 53 .

7 Karl Marx, Manuscritos: economía y filosofía (Madrid: Alianza, 1997 [1844]); S. Freud, "El porvenir de una ilusión, in Obras completas, vol. XXI (Buenos Aires: Amorrortu, 1998 [1927]), I-56.

8 Engels, La situación de la clase obrera en Inglaterra, II-I2.

9 Ibid., 52.
} 
of resistance and rebellion, also operates in the conviction that the workers, "treated like beasts, " are able to "save the consciousness and feelings of their humanity « in their "continuous internal rebellion. $\aleph^{10}$

The young Engels preceded Marx and Freud in the revalorization of the symptom, in the discovery of vital misery in cultural wealth, in problematizing individuality, in envisioning economic personification, and in underscoring material determination. The same young Engels was also a pioneer when he delineated a psychology of the historical determination of the English workers, in whose psyche he found the vestiges of past migrations, cultural fusions, economic changes, etc. Engels criticized those who »only recognize psychological development, the development of the abstract man, outside any connection to the past, when, in fact, the world depends on the past. " ${ }^{\text {II }}$ Such dependency, contradicting the amnesic tendencies of psychology, shows the presence of the past in everything that is present in the world, since everything depends on the past.

\section{Materialism of the Hands: The Origins of Corporeal Psyche}

Considerations of the present and the past are constant in the thought of Engels, and this makes him delve into the most remote, pre-historic and even pre-human times. These explorations always have a materialistic character. He is searching for the historical material determination, which, once discovered, serves to critique the idealistic and amnesic affectations of our knowledge.

If man now tends to explain "his acts through his thoughts" psychologically, it is because previously there were those who made the work "planned by their heads" be »executed by the hands of others. $«^{12}$

\footnotetext{
Io Ibid., 49 .

II Ibid., 99 .

I2 Friedrich Engels, "El papel del trabajo en el proceso de transformación del mono en hombre, in Obras filosóficas (Mexico: FCE, I876), 418.
} 
It was in this way that the mental-intellectual, the future subject of psychology, was abstracted from the corporeal-manual, distancing itself from it in order to devalue it, exploit it, marginalize it, dominate it, and repress it. Such an exercise of power, as a dominant-repressive material determination, allowed the powerful to acquire his apparently elevated and independent existence as spirit, ideal, refined soul, and the psychic, distinct from the somatic and susceptible to being studied by psychology. Like Marx and Freud, Engels redirects the soul-body duality towards the concrete material totality in which it originates through a process of abstraction. Such abstraction is idealization and psychologization, and it is also social dissociation and a cultural-economic division between two parts of the body: the heads that do the planning, the powerful, and the obedient hands that do the work, the exploited. In the Engelsian explanation of the origin of humanity, it is the body that adopts an "erect posture " and thus frees the hands, which, thanks to their lack of occupation, can then turn towards work that becomes progressively more complicated and collectivized, which in turn incentivizes the development of language, the transformation of the senses, and the conversion of the "monkey brain" into a "human brain, " which ends up thinking of itself as an incorporeal, spiritual, ethereal soul. ${ }^{13}$ It is true, then, that the psyche of Engels, as well as that of Marx and Freud, comes from the body and owes everything it is to the body. Humanity stands out, in the end, because of its erect body with its manual work and because of its rational soul with its intellectual work. If the intellect became free from the hands, it is because the hands freed themselves from the erect body. It was "with the hands" that "the head developed" and "consciousness emerged. «"4

Engels's explanation, just like Marx's and Freud's, is perfectly materialistic. Matter is the first, most decisive and most fundamental element. The development of the human psyche is founded on the

I3 Ibid., 4I2-4I8.

I4 Friedrich Engels, „Dialéctica de la naturaleza, « in Obras filosóficas (Mexico: FCE, I883), 299. 
development of language, the brain and the senses. This development is grounded in complex and collective work rooted in turn in the corporeal materiality of the hands, which become independent as they detach themselves from the ground.

\section{Materialism of Reflection: The Unreal Object of Psychology}

In Engels's materialistic approaches to psychology, the theory of corporeal-manual humanization (the material origin of human psychism) is complemented with conceptions of the socio-economic material bases of the historical psychic configurations. The "moral ideas" of each epoch, for example, are ultimately explained by the "economic relationships" from which they come, "consciously or unconsciously. (15 $^{\text {I5 }}$ The existence of private property imposes the moral precept of "thou shall not steal," as well as other contents of our consciousness, thoughts and feelings, invariably »determined by our current realities. $\aleph^{16}$

The Engelsian notion of the historical material determination tends to be schematized in a theory of reflection that ends up establishing itself as the guiding principle of the Leninist perspective ${ }^{17}$ and some of the main currents of Soviet Marxist psychology, ${ }^{18}$ but which originates in Marx's ideas such as the one that defines "the ideal" as "the material translated and transposed into the head of a man. "I9 $^{\text {In }}$

I5 Friedrich Engels, "La subversión de la ciencia por el señor Eugen Dühring (»Anti-Dühring«), « in Obras filosóficas (Mexico: FCE, I878), 81.

I6 Ibid., I58.

I7 Vladimir I. Lenin, Materialismo y empiriocriticismo (Beijing: Ediciones en Lenguas Extranjeras, I975 [1908]).

I8 See Sergei L. Rubinstein, Principios de psicología general (Mexico: Grijalbo, 1982 [1940]); Alexis N. Leontiev, Actividad, conciencia y personalidad (Mexico: Cartago, 1984 [1977]).

I9 Karl Marx, »Postfacio a la segunda edición, in El Capital (Mexico: FCE, 2008 [I873]), xxiii. 
the Engelsian development of reflex theory, we begin with the metaphor of the idealist consciousness critically conceived as a "concave mirror" that inverts things into a "deformed image " of "historical reality, $\varkappa^{2 \circ}$ but, very rapidly, through »religious reflections " of the »real foundation, ${ }^{21}$ we arrive at the representation of ideas and other mental contents as "more or less abstract images of real things and phenomena, ${ }^{22}$ as $»$ reflections in our thought $"$ of the »real conflicts, $«^{23}$ and as »refracted images of the real things. $\aleph^{24}$

The reflected images, identified with the psyche, constitute well-defined and limited objects that apparently allow us to preserve psychology, preventing its object from becoming dissolved in the world and in the body, as happens with the young Marx ${ }^{25}$ and the old Freud. ${ }^{26}$ Unlike Marxist and Freudian theories (which end up assimilating psychism into its economic-industrial and somatic-impulsive material determination), Engels maintains the object of psychology on the superficial field of the mirror that reminds us of the surface to which Freud reduced the ego and its psychology. ${ }^{27}$ The mirror creates a psychic world, deformed and sometimes inverted, that distinguishes itself from the world but does not stop being purely superficial, apparent, and imaginary. If we dig deeper into this world, we will go through it and we'll leave it behind.

It is true that reflection theory preserves psychology, not exactly as a positive science, but rather as a negative study of an unreal

20 Engels, »Anti-Dühring, « 83-84.

2 I Ibid., 276.

22 Friedrich Engels, "Del socialismo utópico al socialismo científico, « in Obras filosóficas (Mexico: FCE, I880), 593.

23 Ibid., 597.

24 Friedrich Engels, "Ludwig Feuerbach y el fin de la filosofía clásica alemana, « in Obras filosóficas (Mexico: FCE, I888), p. 562.

25 Marx, Manuscritos.

26 Sigmund Freud, "Esquema del psicoanálisis, "in Obras completas, vol. XXIII (Buenos Aires: Amorrortu, 1998 [1938]), I33-210.

27 Sigmund Freud, "El yo y el ello, « in Obras completas, vol. XIX (Buenos Aires: Amorrortu, 1998 [1923]), I-66; Sigmund Freud, "El malestar en la cultura, " in Obras completas, vol. XXI (Buenos Aires: Amorrortu, I998 [I929]), 57-I4O. 
object. And if it seems that we are falling into a certain dualism, this no longer divides the world into two realities, physical and psychic, but into the physical reality and the psychic unreality, into the imaginary and the real, into what is reflected and its deformed reflection. Psychology must adhere to the unreal reflection, which is the only psychic thing, which can only be explained by what is real, by what is reflected, by the non-psychic, which, besides being what is reflected, is also the socio-economic thing by which its reflection is deformed on the ideological plane through "inversions « and other "complications. $\ll^{28}$

The deformation of the psychic reflection (the difference that resists its assimilation into the physical-material reality) is determined and constituted by this same reality, by the economic system, by social classes and interests. What is reflected is what deforms itself ideologically, internally, in its own conscious exterior reflection. If men make history unconsciously and not only consciously, it is because their "ideal motives" exist interiorly and do not just reflect exteriorly the real "historical causes" that "determine them" and that »in the minds of the acting men are transformed into those motives. ${ }^{29}$

The Engelsian psychic motive, like the Freudian one, is not just a figuration of its immanent cause but transformation. In other words, what psychology is concerned with is not only the reflection of reality, its conscious deformed representation, but also its unconscious deforming presence, that is, the presence of what reflects itself in knowledge, deforms itself in ideology, and transforms itself in history. The whole deformed psychic reflection, the object of psychology, continues assimilating itself, monistically, to the deforming, reflecting and reflected non-psychic.

28 Engels, »Ludwig Feuerbach, " 562-574.

29 Ibid., 566. 


\section{From Empiricism to Mysticism:}

\section{A Critique of Observational and Experimental Psychology}

We have already seen that Engels's materialism does not lead, through reflection theory, either to the old body-soul duality or to a positive psychological science. We will now be able to observe that the Engelsian materialist psychology is not compatible with either an exclusively cerebral, cranial, neuronal materialism or with a purely observational or experimental empiricism. Engels makes this very clear in his critique of the phrenological projections of psychism on the shapes and parts of the cranium.

In order to arrive at his critique of the empiricist materialism of phrenology, Engels chose a path similar to the one that Freud would choose when distancing himself from the empiricist materialism of the scientificist medicine of the nineteenth century. Both used hypnosis, which, in both cases, demonstrated the mental determination of the physical and the necessity to theorize observation, allowing them to go beyond a series of empiricist excesses and materialist illusions. In the case of Engels, the hypnosis of an adolescent from Manchester, in the winter of $1843-44$, allowed him to refute the supposed phrenological location of certain psychic functions in certain parts of the cranium when he demonstrated that the location could be modified when the subject, in a hypnotic state, was induced to respond to the stimulation of other parts of the body and head. It was in this way that Engels, in his own words, discovered "a series of phenomena as the basis of the phrenological charlatanry, the majority of which were only different in a certain degree to the ones manifested in a waking state. $\aleph^{30}$

Many years before Freud admitted the influence of a sort of hypnosis in social life, specifically in mass phenomena, Engels recognized that the same type of suggestion exists in the waking state and studied it in order to explore the psychic causality of body responses. This cau-

30 Engels, »Dialéctica de la naturaleza, «315. 
sality would not be perceived in the empirical investigations that limited themselves to observation and experimentation, thus condemning themselves to "the chimera, credulity and superstition, « that science often incurs when it "emphasizes simple experience" and "treats thought with contempt. ${ }^{3 \mathrm{I}}$ Do we not have here a sort of premonition of what would be a significant part of the modern psychological discipline? Our psychology, in fact, falls into the "most trivial empiricism" that "despises everything that is theory" and thus leads us to "mysticism. « ${ }^{32}$ The mystical delusion would serve to establish those relationships that we have not established through "theoretical thought, « which, according to Engels, exists precisely to "relate [the facts] to each other « or to "penetrate the relationship that exists between them. «33

\section{The Origin of the Family and Sexual Love: Beyond Psychology}

When readdressing Marx's ethnological notes, Engels ${ }^{34}$ elaborated an intricate structure of theoretical relationships between scarce and doubtful empirical facts related to the pre-historic origins of the family and sexual love. The result was an enormous construct that not only reminds us of the fascinating interpretative excesses of Freud ${ }^{35}$ regarding the primordial horde but also contains valuable ideas that can serve as a bridge between Marxism and Freudian psychoanalysis. Many of these ideas come from Marx and, in particular, from his reading of Morgan, ${ }^{36}$ as in the case of the cardinal theses of primitive communism and its "in-

31 Ibid., 313.

32 Ibid., 320.

33 Ibid., 32I.

34 Friedrich Engels, El origen de la familia, de la propiedad privada y del Estado (Mexico: Colofón, 20II [I884]).

35 Sigmund Freud, "Tótem y Tabú, « in Obras completas, vol. XIII (Buenos Aires: Amorrortu, I998 [1913]), I-I64.

36 Lewis H. Morgan, Ancient Society, or: Researches in the lLnes of Human Progress from Savagery, through Barbarism to Civilization (New York: Holt, 1877). 
comparably superior vitality « over advanced societies ${ }^{37}$ and the (almost Freudian) conception of the monogamous family as a "microcosm of all the antagonisms that would later develop in society and the State. $\$^{38}$

In the work of Engels, based on that of Marx, ${ }^{39}$ we see an expansion of the Marxist field of research from the "means of production" to the "means of reproduction $\aleph^{40}$ and from the "class struggle" to the "struggle between man and woman. $\aleph^{4 \mathrm{I}}$ In this way, the socio-economic sphere, emphasized by Marxism, gives way to the familial-sexual sphere, emphasized by Freudian psychoanalysis. Like Freud, ${ }^{42}$ Engels did not separate both spheres but instead perceived a close relationship between the two: the familial-sexual transition from matriarchate to patriarchate represents the socio-economic victory of "individual property over spontaneous primitive communism, «43 the first "class oppression " was the oppression of »the feminine sex by the masculine sex, «44 and in modern society, "the family man is the bourgeoisie within the family« while »the woman represents the proletariat.«45

If the bourgeoisie is condemned to the monogamous family as a space for the exploitation of women, then the "oppressed classes « can aspire to equality between the sexes and to "marriage for love« and not "for convenience. $«^{46}$ The authentic sexual-loving feeling, the core of psychism in Freudian theory, turns into a privilege of the oppressed in the Engelsian representation of the society of classes. Besides being a social and classist phenomenon, this feeling is historically fixed in the barbarian invasions at the end of the Roman Empire. Engels searched

37 Karl Marx, »Proyecto de respuesta a la carta de V.I. Zasulich, in Obras escogidas de Marx y Engels, vol. III (Moscow: Progreso, 1980 [I88r]), 86.

38 Karl Marx, Los apuntes etnológicos de Karl Marx (Madrid: Siglo XXI y Pablo Iglesias, I988 [1882]), 94-95.

39 Marx, "Proyecto de respuesta«; Marx, Los apuntes etnológicos.

40 Marx, Manuscritos, 35 .

4I Ibid., 74-75.

42 Freud, "Tótem y Tabú."

43 Engels, El origen de la familia, 62-74.

44 Ibid., 74 .

45 Ibid., 84 .

46 Ibid., 8I-93. 
for the pre-historic origin of a gens that emerged from "group marriage in which "whole groups of men and whole groups of women possess each other reciprocally, « thereby "shutting out jealousy" and ensuring the "union of forces" necessary for the "evolution from animality to humanity. « ${ }^{47}$ This group-social origin of being human, of the family and of sexuality contrasts with the familial-sexual origin of humans and social groups in Freud..$^{48}$ However, outside of this contrast, Freud and Engels agree on the historical problematization-relativization of feelings of love, monogamous sexuality and the nuclear family in its modern Western versions. Neither of them accepts universal and eternal categories. Both insist on going beyond psychology, refraining from psychologizing social and cultural institutions.

\section{The Soul Apart: Psychology as the Essence of Ideology}

Engels went all the way back to pre-history in order to explain not only the origins of humanity, the family and sexual love, but also the human psyche as an entity separate from the human body. We have already seen that such an irruption of the object of psychology was explained through the development of the hand, language and brain, with the resulting division between the manual work of the slave and the intellectual work of the master. This Engelsian idea, compatible with the Marxian view, would later give way to the hypothesis that the pre-historic man, "excited by dreams, started to believe that his thought and his sensations were not activities of his body but of a separate soul that lived inside him." And »since that day, man has not been able to stop thinking about the relationship between the soul and the external world. « ${ }^{49}$

47 Ibid., 40.

48 Freud, "Tótem y Tabú«; Sigmund Freud, "Psicología de las masas y análisis del yo, " in Obras completas, vol. XVIII (Buenos Aires: Amorrortu, I998 [I92I]), 63-I36.

49 Engels, »Ludwig Feuerbach," 546. 
The idealistic abstraction of the soul existing apart is reconnected with the concrete, mundane-corporeal totality in the Engelsian approach to psychology. This reconnection compares psychism to a mediating function between the human subject and everything that acts upon him and "moves his life" and must "manifest" itself psychically in his "head«: on the one hand, there is the body that manifests itself in sensations like "hunger and thirst«; on the other hand, there is the "external world " that »reflects" itself in the »shape of sensations, thoughts, impulses and willful determinations. " so $^{5}$ It is in this way that the psychological, individualist dualism of body-and-soul is transformed in a sort of monism in which we can only distinguish two expressions of the same mundane-corporeal totality: its presence in the "propelling or determinant causes" and its representation through psychic reflections in the »ideological forms « of the »ideal or conscious motives. " ${ }^{\text {s }}$

In Engelsian theory, the object of psychology is reduced to an ideological reflection, ideal and conscious, of the world and the body. The psychological abstraction for which this reflection sees itself as a soul apart is the essential mechanism of ideology understood as "an activity that is in charge of thoughts, considered as entities with their own existence and developed in an independent manner, subject only to their own specific laws. «2 $^{52}$ This Engelsian definition of ideology is in itself a definition of psychology. However, more than being a precedent for a future critical Marxist conception of psychology as ideology, ${ }^{53}$ it is also an original representation that is also critical of ideology as psychology.

$50 \quad$ Ibid., 553 .

$5 \mathrm{I} \quad$ Ibid., 566-567.

52 Ibid., 57 I.

53 Carlos L. Sastre, La psicología, red ideológica (Buenos Aires: Tiempo contemporáneo, 1974); Néstor A. Braunstein et al. Psicología: Ideología y ciencia (Mexico: Siglo XXI, 1975); Ian Parker, La psicología como ideología (Madrid: Catarata, 20Io). 


\section{Conclusion: Engels as a Marxist Critic of Psychology}

The Engelsian critique of ideology is also a critique of the psychological mechanism through which a psychic, ideal or intellectual object abstracts itself from the concrete reality, conceived as relatively independent and ruled by its own laws. This mechanism is psychology itself and, consequently, when he criticized it, Engels also criticized psychology. In contrast with what is criticized, Engelsian research incorporates the psychic object in its concrete social, economic and historical reality on which it depends and by whose laws it is ruled. We can say, in this sense, that Engels was not so much a psychologist as a critic of psychology.

The Engelsian critique of psychology began early on in his investigations of English workers, in which the psyche spreads out of its own domain and dissipates through society, the economy and history. Then, this object of psychology is presented as a product of the classist division between head and hands, a division upon which psychology would be founded and which would be fought by the communist in his struggle against classism. In his fight against class society and its psychological product, Engels would reduce the psychic to an unreal, apparent and superficial condition, a reflection in which there is only the reflected non-psychic and its distortion, which, ultimately, will be explained by the real reflected and not by the unreal reflection.

As we have seen, Engels's Marxist critique does not stop at a strictly empirical psychology in which he alerts us to the dangers of a mysticism that would compensate for the lack of theory. Theoretical reflection, in the direction that Engels sets, can only take us beyond the boundaries of psychology, even when dealing with the more intimate and personal elements (such as sexual love), which are redirected to their historical, group-social origins. How can we not go past the psychology that we investigate when Engels conceives it as a simple surface, the appearance and representation of that which hides from us? 


\section{Works Cited}

Braunstein, Néstr et al. Psicología: Ideología y ciencia. Mexico: Siglo XXI, 1975. Coe, Samuel P. Contemporary Psychology in Marx and Engels. New York: American Institute for Marxist Studies, 1978.

Engels, Friedrich. La situación de la clase obrera en Inglaterra. Moscow: Progreso, 1980 [1845].

- . »El papel del trabajo en el proceso de transformación del mono en hombre.« In Obras filosóficas, 4I2-422. Mexico: FCE, I876.

—. »La subversión de la ciencia por el señor Eugen Dühring (»AntiDühring«).«In Obras filosóficas, I-284. Mexico: FCE, I878.

-. "Del socialismo utópico al socialismo científico."In Obras filosóficas, 578-636. Mexico: FCE, 1880.

—. "Dialéctica de la naturaleza."In Obras filosóficas, 285-533. Mexico: FCE, I883.

-. El origen de la familia, de la propiedad privada y del Estado. Mexico: Colofón, 20II [I884].

—. "Ludwig Feuerbach y el fin de la filosofía clásica alemana."In Obras filosóficas, 535-575. Mexico: FCE, I888.

Freud, Sigmund. »Tótem y Tabú.«In Obras completas, vol. XIII, I-I64. Buenos Aires: Amorrortu, 1998 [1913].

—. "Psicología de las masas y análisis del yo."In Obras completas, vol. XVIII, 63-I36. Buenos Aires: Amorrortu, 1998 [I92I].

—. "El yo y el ello." In Obras completas, vol. XIX, I-66. Buenos Aires: Amorrortu, 1998 [1923].

—. "El porvenir de una ilusión.«In Obras completas, vol. XXI, I-56. Buenos Aires: Amorrortu, 1998 [1927].

—. "El malestar en la cultura.«In Obras completas, vol. XXI, 57-I40. Buenos Aires: Amorrortu, 1998 [1929].

—. "Esquema del psicoanálisis.«In Obras completas, vol. XXIII, I33-210. Buenos Aires: Amorrortu, 1998 [1938].

Lenin, Vladimir I. Materialismo y empiriocriticismo. Beijing: Ediciones en Lenguas Extranjeras, 1975 [1908].

Leontiev, Alexis N. Actividad, conciencia y personalidad. Mexico: Cartago, I984 [1977].

Marx, Karl. Manuscritos: economía y filosofía. Madrid: Alianza, 1997 [1844]. 
—. "Postfacio a la segunda edición." In El Capital, xvii-xxiv. Mexico: FCE, 2008 [1873].

—. "Proyecto de respuesta a la carta de V. I. Zasulich."In Obras escogidas de Marx y Engels, vol. III, 85-90. Moscow: Progreso, 1980 [I88I].

-. Los apuntes etnológicos de Karl Marx. Madrid: Siglo XXI y Pablo Iglesias, I988 [1882].

Morgan, Lewis H. Ancient society; or, researches in the lines of human progress from savagery, through barbarism to civilization. New York: Holt, 1877.

Parker, Ian La psicología como ideología. Madrid: Catarata, 2oIo.

Pavón-Cuéllar, David. "Las dieciocho psicologías de Karl Marx.» Teoría y Critica de la Psicología 5 (2015): 105-132.

Rubinstein, Sergei L. Principios de psicología general. Mexico: Grijalbo, 1982 [1940].

Sastre, Carlos L. La psicología, red ideológica. Buenos Aires: Tiempo contemporáneo, 1974. 


\title{
Engels and Evolutionist Ethnology ${ }^{1}$
}

\author{
Maria Rosário de Carvalho
}

Strictly speaking, for the anthropologist, the title of this article brings up the issue related to the so-called 'primitive society, , which gave rise to many ideological positions. These ideological positions shared the belief that societies were based on blood or in soil, and that the consequent principles of descendance and territoriality could be equated to race and citizenship. The evolutionary or evolutionist structure offered the hope that although institutions may vary from society to society, they formed a hierarchy through which all would eventually progress. ${ }^{2}$

\section{The Antecedents to Lewis Morgan}

The first ideas developed on the theme had India as locus empiricus, apparently the central political issue of the I850s, and the dispute over the prevalence of law with regard to traditional customs and principles related to individual land rights derived from the British government and considerable parts of the utilitarian current. Henry S. Maine (I822-I888) intervened in the dispute, advocating for retaining the traditional system in India and, therefore, opposing a civil law based on a simplified English law. In fact, he and Bentham were on

I The present article is an extended translation of "Engels e a etnologia evolucionista, " in Friedrich Engels e a ciência contemporânea, eds. Muniz Ferreira, Ricardo Moreno, and Mauro Castelo Branco (Salvador: EDUFBA, 2007), 65-84. The editor would like to thank the author and the publisher for the possibility to include the translation in the present volume.

2 Adam Kuper, The Invention of Primitive Society (London, Routledge, 1988). 
opposite sides: whereas Bentham believed that government was based on a social contract established by individuals for the protection of property, Maine proposed that original societies were based on families related by status and shared property. The so-called sprimitive societies were subjected to a patrimonial despot. ${ }^{3}$

In his book Ancient Law, Maine sought to offer a solution to the conflict between the legal ideas of India and those of the British Empire through a legal history of the family under the mantel of Indo-European nations along a spectrum that connected India with ancient Germany and the British Crown through Rome. Nothing, in the light of that argument, prevented India from developing under British guidance, as had previously happened with Germany thanks to Rome.

The assumption, generalized at the time, that sprimitive peoples carried out female infanticide indiscriminately was one of the means used by McLennan to attack Maine's patriarchal theory. His argument imputed the practice of the large-scale search for women in external areas, which gave rise to the term sexogamy.، On the other hand, since there was supposed to be a permanent struggle between communities, exogamy could not have resulted from a peaceful modality of approach but from acts of violence on the part of men in the position of beings forced to capture wives. These women, captured in small numbers relative to the demand, would be shared in a group under an arrangement called rough polyandry.< The more or less obvious conclusion was that, under such circumstances, it was difficult to establish paternity, as a result of which the first system of kinship would have to be based on bloodlines defined only by the female lineage. ${ }^{4}$ As Radcliffe-Brown noted many years later (I95I), McLennan historically interpreted the custom of presenting the taking of a woman by one group from another as an act of hostility as a vestigial manifestation of the primitive conditions of human society. He presented the kidnapping or capture of women by another group

\footnotetext{
3 Ibid., 7 .

4 Ibid., 37.
} 
as the only way to obtain wives and generalized its diffusion. ${ }^{5}$ In this way, the excesses of evolutionist formulations were highlighted and delegitimized.

The roughest forms of women sharing would have increasingly given way to a more refined and restrictive arrangement, in which uterine brothers with a recognized degree of solidarity would share a woman, a modality called `Tibetan polyandry, considered by McLennan to be a stage in the development of marriage whose most important implication would be the sharing of descendance by the sons of a woman. In practice, Tibetan polyandry constituted another step towards the recognition of paternity. The idea of paternity, in turn, became firmly established, and its development was stimulated by the parallel growth of the welfare economy, which resulted from the necessity of having rules to govern the transmission of property between generations.

As the reader may realize, these ideas are built upon precarious correlations and false assumptions. This is due to their character as preliminary outlines in attempts to establish a nexus between past and present according to an ascending linear march. Regarding literature that deals particularly with kinship, Radcliffe-Brown incisively pointed out that the theories that produced it "can only be called pseudo-historical, «imputing upon them unhappy results through the "legacy of erroneous ideas." This legacy would be gradually discarded in favor of the development of field studies that did not refer to the origin of social systems, except when the actual history was known, in a clear allusion to the conjectures of McLennan, Maine and their contemporaries that ventured into this area. ${ }^{6}$

5 Alfred Reginald Radcliffe-Brown, "O Método Comparativo em Antropologia," in Antropologia, edited by J. C. Melatti (São Paulo: Ática, I978), 53.

6 Alfred Reginald Radcliffe-Brown, "Introducción," in Sistemas Africanos de Parentesco y Casamento, eds. Alfred Reginald Radcliffe-Brown and Daryll Forde (Barcelona: Editorial Anagrama, 1982), 60. 


\section{Lewis H. Morgan and the Order of Social Development}

In I871, a more elaborate version of McLennan's thesis- that the first systems based on kinship would have been matrilineal, and the order of social development had the sequence tribe/gens/family-was published by an American attorney, Lewis Henry Morgan. The Primitive Society provided a long and ambitious record of political and social evolution that, similarly to McLennan's formulations, started with a matrilineal group and ended with the triumph of the state and the family. However, unlike his predecessors, Morgan had established, for the purposes of his research, a relationship with the Iroquois of New York, from whom he collected copious kinship terminology, and with the Crow from Missouri, from whom he recorded information on rituals and religious behaviors. ${ }^{7}$

Morgan was particularly interested in issues concerning American ethnology and, before writing The Primitive Society, he published Letters on the Iroquois by Skenandoah (American Review, 1847), League of the Iroquois (I85I), and Systems of Consanguinity and Affinity of the Human Family (I87I). In this last work, hereafter referred to as SCAHF, he distinguished descriptive systems - in which there were different terms for linear and collateral relatives, i. e. for father and mother, husband and wife, brother and sister, and son and daughter, none of which was applied outside the family nucleus_-and he claimed that such systems would mirror the reality of biological kinship, clearly demarcating degrees of blood relationships. ${ }^{8}$ The systems of classification, on the contrary, would not reflect the natural degrees of kinship but would bring relationships of different types together under one term, which could refer to father, brother of the father, or son of the

7 Lewis Henry Morgan, A Sociedade Primitiva, Vol. I (Lisbon: Presença; São Paulo: Martins Fontes, 1976), I91.

8 The descriptive systems would be characteristic of all North American indigenous peoples (with the exception of the Inuit), southern Indian, Chinese, Southeast Asian and Pacific peoples, which for Morgan showed the unity of North American indigenous peoples and its relationship with Asian peoples. 
brother of the father, confusing different forms and degrees of biological parentage, as recorded among the Iroquois. ${ }^{9}$

The question, as Levi-Strauss pointed out, is that kinship should be interpreted as a phenomenon of structure and not as the result of the simple juxtaposition of terms and customs. ${ }^{\text {10 }}$ Furthermore, the systems of kinship cover two very different types of reality, that is, the terminological system (system of vocabulary) and the system of attitudes, of a psychological and social nature. It is additionally always necessary to distinguish between two types of attitudes, i. e. those that are diffused and deprived of an institutional character, and obligatory attitudes, sanctioned by taboos or privileges and expressed through fixed rituals. "In addition to automatically reflecting a nomenclature, these attitudes often appear as secondary elaborations destined to resolve contradictions and overcome insufficiencies inherent to the terminological system. " ${ }^{\text {II }}$

Morgan, on the contrary, gave excessive relevance to terminologies to the detriment of the system of attitudes. When opposing McLennan's refusal to admit that the systems that he had classified in terms of consanguinity and affinity (purely conventional and only established as a means to address one other when greeting), Morgan observed that a system of forms of greeting is ephemeral and postulated that a system of consanguinity is something very different, to the extent that the relationships of kinship that characterize it derive from the family and the matrimonial regime, being more permanent than the family itself since the latter evolves while the system remains immutable. This conception led to: a) the reification of kinship relationships, apprehended as mere expressions of the real conditions in which society lived in the period that the system was constituted, exerting an important influence on the daily life of human beings; and b) the conclusion that the uniformity

9 Lewis Henry Morgan, Systems of Consanguinity and Affinity of the Human Family (Washington, DC: Smithsonian Contributions of Knowledge, I87I).

Io Claude Lévi-Strauss, As Estruturas Elementares do Parentesco (Petrópolis: Paz e Terra; São Paulo: EDUSP, 1976), I64.

II Claude Lévi-Strauss, Antropologia Estrutural (Rio de Janeiro: Tempo Brasileiro, I970), 55-56. 
of immense regions of the globe and its preservation through very long periods of time should be the link to bring about marriage rules. ${ }^{\text {I2 }}$

Thus, he tried to explain the origin of two systems of consanguinity and affinity from the forms of marriage and family from which they derived, admitting via hypothesis the existence of those forms. Having obtained a satisfactory explanation for each system, the previous existence of each modality of marriage and family could be deduced from the system that they explained. He also admitted that the sequence postulated was based, in part, on hypotheses, but it was sufficiently corroborated by the evidence to be taken into consideration. Future ethnologists were left to »establish a full picture of this sequence. $\aleph^{13}$

Let us see how he proceeded in the case of a consanguineous family. Considered the first and oldest form of the family institution, it would have stopped existing "even among the most backward savage tribes, " hence, it would not be possible to provide direct evidence of its existence. ${ }^{14}$ The proof, then, that it had existed at a given moment in human history would have to be conclusive- - otherwise it would not demonstrate our thesis«— that is, strengthened by a system of consanguinity and affinity that for many centuries survived the marriage customs that had presided over its birth and whose presence demonstrated that this family existed at the moment the Malay system took shape. ${ }^{\text {is }}$ We are, then, confronted with something that resembles the petition of principle in Aristotelian terms: »Revealing relationships of kinship that ruled the consanguineous family and its existence implies the existence of this type of family. Furthermore, it strengthens the theoretical certainty of the existence of the consanguineous family at the time it was established. $\ll^{16}$

Another criticism directed at Morgan (who did not doubt the value of the terminologies of kinship to reveal the method of organizing relation-

I2 Lewis Henry Morgan, A Sociedade Primitiva, Vol. II (Lisbon: Presença; São Paulo: Martins Fontes, 1978), 27I.

I3 Ibid., I38.

I4 Ibid., I39.

I5 Ibid., I39-I40.

I6 Ibid., I40. 
ships) was his attempt to classify all terminological systems using the two types referred to above when it was perfectly possible to use both classificatory and descriptive principles, as Daryll Forde, among others, proved for the Yakö, a people established in the Ogoha province of southern Nigeria. According to Forde, their system constitutes an example of the total and simultaneous development of both groups of matrilineal and patrilineal relatives that, at the time of his fieldwork, were suffering from the impact of Western institutions but continued to give both lines of affiliation the same relevance. Forde identified the Abayong, Agwa'aguna and the Enna as other groups holding a similar dual system to the Yakö. ${ }^{17}$

The restriction ascribed to $S C A H F$ did not diminish its relevance, so much so that Claude Levi-Strauss did not hesitate in saying that Morgan founded, simultaneously, social anthropology and kinship studies $^{18}$ and that he and Frank Hamilton Cushing were the great precursors of structural research. ${ }^{19}$

\section{The Primitive Society}

In The Primitive Society, Morgan postulated that "the history of humanity is one in its origin, its experience, and its progress. ${ }^{20}$ Endowed with essentially identical intelligence and a similar physical organism by virtue of their common origin, in the same ethnic period, humans have always arrived at the same results, in all times and all places. ${ }^{21}$ It was this trait that led man to the invention of the arrow, which expresses the thought of a wild man, the fusion of iron ore, which represents the more developed intelligence of the barbarian, and, last-

I7 Daryll Forde, "Doble Filiación entre los Yakö, « in Sistemas Africanos de Parentesco y Matrimonio, eds. Alfred Reginald Radcliffe-Brown and Daryll Forde (Barcelona: Editorial Anagrama, 1982 [1950]), 317.

I8 Lévi-Strauss, Antropologia Estrutural, 325.

I9 Ibid., 3I4.

20 Morgan, Sociedade Primitiva I, 8.

2I Morgan, Sociedade Primitiva II, 308. 
ly, steel, the materialized triumph of civilization. Finally, the labors, difficulties, and successes of the barbarians and savages would have been part of the "plan of the Supreme Intelligence, " who envisioned to make from the savage a barbarian, and from this a civilized man. ${ }^{22}$

His purpose was to prove that human progress continued its march through successive ethnic periods, internally demarcated by certain subsistence arts, as evidenced by inventions, discoveries, and the development of ideas of government, family, and property. In a peremptory way, he stated that these inventions and discoveries were directly related to the progress of humanity, and as social and civil institutions developed from original seeds of thought, they would represent the same scale of development. Taken together and compared, these institutions, inventions and discoveries tended to demonstrate the origin of humanity in parallel to the needs of humans at the same stage of development and the identity of the activity of the human spirit in similar social conditions. ${ }^{23}$

Organization into gens, fraternities, and tribes would have prevailed throughout the longest part of the most recent savage stage and throughout the period of barbarism. The family, in a similar manner, would have assumed successively different forms, giving rise to systems of consanguinity and affinity that would attest to the experiences of humanity during the transition from the consanguineous family to the monogamic family. Finally, forms of government, under the two general systems, had very different bases. The first system depended on people and personal relationships, and it constituted a society whose organizing unity was the gens, from which the fraternity, the tribe, and the confederation of tribes would emerge (through successive integration); the second system was based on territory and property and was characterized by constructing a state (civitas). The city or agglomerate, circumscribed by limits in whose interior property was established, constituted the foundation of the state and would lead to political society. The notion of private property presented the same evolution and the same development. ${ }^{24}$

\footnotetext{
22 Ibid., 308-3io.

23 Morgan, Sociedade Primitiva I, 8.

24 Ibid., 8-9, 16-17, I9.
} 
The principle that apparently operated throughout human history was a tendency towards moral progress in the form of the organic movement of society to distance itself from unfavorable conditions. The decline of classificatory systems of kinship and their replacement by descriptive ones would have been impelled by the influence of relationships of property, a sign of so-called scivilization. The distribution of goods would be observed, and there was thus a sequence in the direction of concentration: if, in the so-called savage state, goods were distributed by members of the gens, in the early phase of barbarism they were restricted to the agnatic relatives, and finally, in the latter phase, goods were transmitted to sons as sole heirs. ${ }^{25}$

Ethnic Periods and Arts of Subsistence

I. FIES Natural means of subsistence

II. FMES Consumption of fish and use of fire

(Australia and Polynesia)

III. FSES Invention of the bow and arrow

(Coastal Tribes of the Americas)

IV. FIB Invention of pottery

(Amerindians east of the Mississippi)

V. FMB Animal domestication in the Oriental Hemi-

sphere and irrigation, brick buildings in the

Western hemisphere (Indians of New Mexico,

Mexico, Central America and Peru)

VI. FSB Smelting of iron ore (Homeric Greek tribes, Ita-

lic tribes, Germanic tribes during Roman times)

VII. Civilization Use of the phonetic alphabet and the production of literature

25 Morgan, Sociedade Primitiva II, 62. 
Source: A Sociedade Primitiva I, 20-24

According to Morgan, the systematic progress of ethnology demanded that the development of the normal living conditions of savage and barbarian tribes be studied in regions where the institutions were homogeneous. Thus, Polynesia and Australia would be the best places for the study of societies in a savage state, whereas for the early and later phases of barbarism, the best field of study would be the Americas during the time of their discovery. ${ }^{26}$

\section{Development of Types of Family}

- Promiscuous intercourse

- Intermarriage or the cohabitation of brothers and sisters

- Communal family (first stage of the family)

- Hawaiian custom

- Malay form of the classificatory system

- Tribal organization

- Turanian and Ganowanian systems of relationships

- Marriage between couples

- Barbarian family (second stage of the family)

- Polygamy

- Patriarchal family (third stage of the family)

- Polyandry

- Emergence of private property and establishment of linear succession

- Civilized family (fourth stage of the family)

- Decline of classificatory systems of kinship, replaced by descriptive systems

Morgan dedicated close to half of his book to the development of the system of the gens, based on the fact that it had survived the greater part of human history. The stages of progress were illustrated by five

26 Ibid., 206. 
crucial case studies, each one of which was given its special relevance: Australian, Iroquois, Aztec, Greek, and Roman.

The Australian case represented the most primitive system, being only a short distance from the initial condition in which brother supposedly married sister in a form of incestuous group marriage; the Iroquois material was used to illustrate the subsequent stage of evolution in which the democratic gens was associated with larger federations; and the Aztecs, who would follow, were at the middle stage of barbarism. Later, Morgan classified the Aztec stage as a more advanced version of the Iroquois federation. His particular interest in the Aztecs was related to his attempt to refute the sources represented by Spanish chroniclers in which the Aztec monarchy was presented as analogous to European monarchies. ${ }^{27} \mathrm{He}$ gave credence to the chronicles insofar as they described the actions of the conquistadors and the personal characteristics of the Indians, as well as their technology, diet, and dress; however, Morgan did not give any value to what the chroniclers wrote about the natives society and government. In this respect, the value of the Spanish chroniclers narratives was "practically null, since they did not know or learn anything with regard to the issue, « leading to his rejection of their formulations and to his study of the issue from the beginning, "using, however, that which is in concordance with what we know about Indian society. ${ }^{28}$

As far as the Greeks are concerned, their primitive government was essentially democratic, as gens, fraternities, and tribes were organized as self-governed bodies based upon the principles of freedom, equality, and fraternity, whereas the Roman empire was artificial and illogical, albeit capable of great achievements. ${ }^{29}$

When the data produced by Morgan or collected from the available bibliography proved insufficient to support his ambitious project, he complemented them with other means, such as established English informants or bureaucratic or religious injunctions in different

27 Morgan, Sociedade Primitiva I, 69.

28 Ibid., 225 .

29 Morgan, Sociedade Primitiva II, 70. 
parts of the world. For Australia, for example, he used the help of English missionaries, and for other ethnographic contexts, he used the most diverse sources, such as Edward Tylor (Early History of Mankind and Primitive Culture), Homer (The Iliad and The Odyssey), Herrera (History of America), Lucretius (De Rerum Natura), Prescott (Conquest of America), Fernando de Alvarado Tezozomoc (Mexican Chronicle), Titus (Germania), Cicero (Topica), and many others.

\section{The Reception of Morgan by Engels}

Several authors, in the field of anthropology, disagree on the point that Morgan actually developed a materialist theory of history, taking into consideration that he also saw socio-political progress to be a signal of God, part of the master plan of the Supreme Intelligence, in which the barbarian was preceded by the savage and followed by civilization..$^{30}$ What would have motivated Engels and Marx to embrace his ideas with such enthusiasm? In order to answer this question, it may be necessary to remember that Marx published little about non-European societies in that field, his most important contribution was his model of Asian production, a type of society with state organization whose village communities held communal land and would distribute the surplus internally, except for a certain amount reserved for the state. This model presented theoretical problems for Marxism, in part because Marx did not consider development to be geographically specific, and in part because it did not clearly signal the direction that societies of that type could take in terms of development. ${ }^{3 \mathrm{I}}$

Towards the end of his life, Marx became attracted to new anthropology, having written extensive notes on the works of Morgan and his predecessors, notes that he never got to use. Engels then used these notes as the starting point for The Origin of the Family, Private

\footnotetext{
30 Ibid.

3I Kuper, Invention of Primitive Society, 74.
} 
Property, and the State (1884), hereafter referred to as OFPPS. There is no way to know if Engels expressed Marx's enthusiasm in an exaggerated form or in what way Marx related Morgan's sequence of development to the Asiatic model. ${ }^{32}$ However, the consensus is that Morgan became especially relevant within the Marxist tradition. The aspect of Morgan's theory that interested Engels the most was his rediscovery of the primitive matriarchal gens as the first stage of the gens in primitive peoples, which would be as important to anthropology as Darwin's theory was to biology and the Marxist theory of value was to political economy. The evolutionary importance of this discovery was in showing a history of the development of the family as the product of historical processes and not as a natural institution.

It is worth noting, preliminarily, the various convergences among the formulations of Morgan, Marx, and Engels, starting with the importance given to kinship relations within the context of so-called pre-capitalist societies. Claude Levi-Strauss, in responding to criticisms leveled by Georges Gurvitch regarding his distinction between stationary, fluctuating, and cumulative history, observed, quite appropriately, that the idea that societies considered primitive were ruled by links of consanguinity (kinship structures) and not by relationships of production is frequently expressed in Marx and Engels, who argued that, if those societies were not destroyed from the outside, they could perpetuate themselves indefinitely. ${ }^{33}$

These themes, the French anthropologist reminds us, are constantly taken up in Capital in relation to Indian and Germanic societies, which were, at that time, more 'primitiver than Marx thought. These themes were generalized by Engels in Anti-Dühring and OFPPS. ${ }^{34}$ In order to clarify the parallel between the "Germans of Tacitus" and the "American Redskins, « Engels said:

32 Lawrence Krader, The Ethnological Notebooks of Karl Marx (Assen: Van Gorcum, I974).

33 Kuper, Invention of Primitive Society, 72-73.

34 Lévi-Strauss, Antropologia Estrutural, 36I-362. 
The similarity is in fact more striking in that the mode of production is so fundamentally different-here hunters and fishermen, without husbandry or agriculture, there the nomadic breeding that passes to the culture of the fields. This proves precisely how much, at this stage, the mode of production is less decisive than the degree of composition of the old ties of consanguinity and the ancient reciprocal community of the sexes in the tribe. Without that, the Tlingit of the formerly Russian America ${ }^{35}$ could be copies of the old Germanic tribesmen. ${ }^{36}$

In response to Kautsky's attempt to interpret primitive societies according to historical materialism and through the exclusive use of economic notions, such as that of barbarism, Engels replied: "It is not barbarism that proves the primitive character but the degree of integrity of the old links of consanguinity in the tribe. It is those that must be established in a particular case before one is able to draw conclusions for particular tribes from those phenomena. ${ }^{37}$ For all these reasons, we can conclude that Morgan's attempt to elaborate a new typology of systems of kinship, in light of the knowledge acquired and the emphasis given to the organization of the gens, attracted the genuine interest of Marx and Engels.

\section{Was the Materialist Conception of History Rediscovered by Morgan?}

In the preface to OFPPS, Engels states, dramatically, that:

...the following pages will be, in a way, the execution of my will. Marx was willing to present the results of Morgan's research in rela-

35 Russian colonial possessions in America between 1733 and I867, currently the U.S State of Alaska and the most distants settlements to Southern California and Hawaii.

36 Ibid., 362.

37 Letter from Engels to Marx, December 8, I882, cited in Lévi-Strauss, Antropologia Estrutural, 364-365. 
tion to the conclusions of his (to a certain extent, our) materialistic analysis of history, to clarify in that way, and only in that way, his entire scope. In America, Morgan rediscovered, in his own way, the materialistic conception of history, formulated by Marx forty years earlier — and, based on it—arrived, contrasting barbarism and civilization, at the same essential results as Marx. I have, however, not only the detailed excerpts that Marx obtained from Morgan's work but also the criticisms that he annotated that I will reproduce whenever they seem relevant. ${ }^{38}$

Engels points out that the social order in which men live at a given time or in a given country is conditioned by two types of production, that is, by the degree of development of labor, on the one hand, and of the family, on the other; the less developed labor is, the more restricted the quantity of its products and, consequently, the wealth of society are; "with all the greater strength is the dominant influence of the bonds of kinship over social regime manifested. «" Thus, Morgan's great merit was the discovery and the reestablishment, in its essential traits, of this pre-historic foundation of our written history, as well as in finding, in the free unions of gens among North American Indians, the key to deciphering important enigmas, until then unresolved, about the history of Greece, Rome, and Germany. ${ }^{40}$

As is widely known, for the materialist conception, political economy constitutes the fundamental and determinant factor in man's historical and social life. In this sense, Marxist materialism is, in fact, "economic materialism, " which identifies the trace of the union between the evolution of nature ${ }^{41}$ and the evolution of human society

38 Letter from Engels to Kautsky, February IO, I883, cited in Maximilien Rubel, Karl Marx: Essai de biographie intellectuelle (Paris, I957), 30I-302.

39 Friedrich Engels, A Origem da Família, da Propriedade e do Estado (Lisbon: Presença), 7-8.

40 Ibid., 8.

4I Ibid., 9. 
in the economic process conceived as "material production " through which men reproduce and continuously develop their means of existence and, therefore, their existence and everything contained in it. Every other event of historical, social, and practical existence, including spiritual existence, has less influence over the development of everything. ${ }^{42}$

Engels's embracement of the way in which Morgan rediscovered the materialistic conception of history was not without restrictions. In the history chapters devoted to Greece and Rome, Engels did not limit himself to reproducing the documentation of Morgan but also increased the data at his disposal; the section concerning the Celts and the Germans was sessentially his, since Morgan's documents on the matter were second-hand; and, finally, he was forced to recreate the whole economic argument, which underscored that although it was sufficient for Morgan's objective, it was not for his. ${ }^{43}$

In this manner, the initially enthusiastic reception became more rhetorical, and Engels would later tone down his wording when he recognized that Morgan was the first who knowingly introduced a precise order to the pre-history of humanity and did so in light of the assumption that all of the great eras of human progress coincide, more or less directly, with the times when sources of subsistence broaden. The parallel development of the family, however, did not offer criteria that were as conclusive for delimiting the different periods as those offered by the arts of subsistence. ${ }^{44}$

42 Karl Korsch emphasizes the value that Marx attributed to the complement and reasoning of his socio-historical materialism for the "natural sciences. "To prove it, he cites the observation that he made about Darwin's theory of natural selection in a letter dated December 19, I869: "Although roughly elaborated, as is the English custom, this is a work that contains the natural history foundations that serve our ideas." Karl Korsch, Marxismo e Filosofia (Porto: Ediçóes Afrontamento, I966), I60.

43 Ibid., I58.

44 Engels, Origem, Io. 


\section{Translator ... Traitor?}

The assumption that the Asiatic mode of production was no more in I884, in OFPPS, became a problem for specialists in the evolution of Marxist theory. As the reader may remember, for Marx, the Asiatic mode of production is, necessarily, the one that remains for the longest, which is implicit in its assumptions; the individual does not become independent from the community, and there is a self-sustaining circle of production, a unity of agriculture and manufacture. If the individual changes his relationship with the community, he changes the community and acts in a destructive manner upon it, and thus upon its economic assumptions. "In the Oriental model, the loss of property is almost never possible, except through completely external influences, since the individual member of the community never enters into a free relationship to lose his economic objective with the community. «45

The exchange of letters of June 1853 between Marx and Engels is evidence of the conviction of both that the absence of private property is the "key to the whole Orient." That is the conclusion of Jean Chesneaux, who problematized the influence that the publication of The Primitive Society, which Engels read in 1883 , had on him, and he recalled that Plekhanov had proposed to attribute this influence to the apparent change in Engels's attitude. However, instead of supporting the accusation that Engels had been disloyal to Marx's opinion on the Asiatic mode of production, Chesneaux thought that it was more appropriate to determine the reach-decisive, but limited—of OFPPS, which did not seek to analyze the evolution of all human societies. ${ }^{46}$

In the prologue to the republished version of the article $" \mathrm{~A}$ notion of the 'Asiatic mode of production of the evolution of society, " published originally in 1964, Maurice Godelier admits having been wrong in concluding that Engels, after

45 Ibid., 3I.

46 Karl Marx, Elementos Fundamentales para la Critica de la Economía Política (Grundisse) (Madrid: Siglo XXI, I857-I858), 446-455. 
reading Morgan, had abandoned the concept of the Asiatic mode of production. A more detailed analysis and the chronology of the correspondence between Marx and Engels left no doubt in his mind that neither of them rejected the ideas elaborated from I853 to I877 on the existence of despotic forms of state, as edified in Asia, Russia, and other regions. ${ }^{47}$

He notes that Marx, in I88I, after reading Morgan, affirmed, once again, the existence of a despotic state in Russia and tried to discover its foundations, not in the necessity for great works but in the dispersion and isolation of agricultural communities in an immense territory, and in the Mongol domination. On the other hand, in OFPPS, he left behind the histories of Asia and America because, contrary to the history of the Greco-Roman West, the former would not develop, according to Engels, more direct forms of transition from old clannish communities to the typical forms of states and class societies. In this way, OFPPS deepens, in light of Morgan's formulations, one of the ways of transitioning to the state that Engels suggested in Anti-Dühring, that is, the Western way that leads to a generalization of productive slavery and mercantile production. Godelier claims, therefore, that there is continuity between Grundisses, Anti-Dühring, and OFPPS, the theses on the Asiatic mode of production having remained valid for Engels and continuing to designate a form of transition from societies without classes to societies with classes, "a transition that is incomplete and motivates slowness or stagnation in social development. (4 $^{8}$

The position defended by Godelier seems to me to be the correct one, which it may be possible to demonstrate by referring directly to OFPPS. At the end of this book, Engels investigates the general

47 Jean Chesneaux, "O Modo de Produção Asiático: Algumas Perspectivas de Pesquisa, "in O Modo de Produçáo Asiático, ed. Centro de Estudos e de Pesquisas Marxistas (C. E. R. M.) (Lisbon: Seara Nova, 1974), 22-23.

48 Maurice Godelier, "A noção de modo de produção asiático e os esquemas marxistas de evolução das sociedades, "in O Modo de Produção Asiático, ed. Centro de Estudos e de Pesquisas Marxistas (C. E. R. M.) (Lisbon: Seara Nova, 1974), 53. 
economic conditions that undermined, in the so-called later phase of the barbarian stage, the organization of the gens-based society and made it disappear. Up until this stage, production had been essentially collective, and consumption also took place under a regime of direct distribution of goods in the midst of small or large communal collectivities. Production, then, did not overlap with producers. I suppose that Engels was describing the Asiatic model, in whose mode of production the division of labor was gradually introduced. It was in this way that production and common appropriation were undermined, with individual appropriation emerging as the dominant rule, which opened the path to mercantile production, in short, the dominant model. ${ }^{49}$

\section{Final Considerations}

For Franz Boas the question related to the origin of universal ideas was the most difficult problem in anthropology. He rebelled against the point of view that the same ethnological phenomena always have the same causes, as well as against the generalization that the similarity of ethnological phenomena found in different regions of the world is proof that the human mind obeys the same laws in all places. $\mathrm{He}$ urged anthropologists to demand that the causes from which a phenomenon developed be investigated and that comparisons be restricted to those phenomena that could be proven to be effects of those same causes. ${ }^{50}$ Boas became a firm opponent of what he designated as the excesses of evolutionism and emphasized that the evolutionist hypothesis implied the idea that modern civilization represented the highest cultural development, with the implication that all other cultural types were considered more primitive. He concluded: "We retrospectively build an orthogenetic development in the direction

\footnotetext{
49 Ibid., 53-55.

50 Engels, Origem, 209.
} 
of our own modern civilization." We contrapose, then, against the general evolutionary scheme, the admission of the existence of diverse "definitive and coexisting " types of civilization..$^{\text {sI }}$

Claude Levi-Strauss understood Boasian anti-evolutionism as a reaction derived from the fact that he used mainly mechanical models (whose constitutive elements are scaled according to the phenomena studied), for which a notion of evolution does not have a heuristic value. ${ }^{52}$ In doing so, he identified the weakness of evolutionist studies, that is, the utilization of mechanical models when statistical models should have been employed. The correct interpretation of Levi-Strauss eliminated, however, the strong critical position of Boas in relation to the evolutionary schemes developed throughout the nineteenth century, in which he identified a strong tendency to combine the historical aspect with the subjective evaluation of the various phases of development, the present serving as the standard of comparison.

The frequently observed change from supposed simple forms to more complex forms, from uniformity to diversity, was interpreted as a change from something of less value to something of greater value. Thus, he accurately concluded that the historical view assumed, in many cases, a poorly concealed teleological matrix. ${ }^{33}$ Furthermore, he observed that the generalizing method of the science of the period, according to which a real event did not possess scientific value in itself but only to the extent that it led to the discovery of a general law, collided with a purely historical vision, causing the subordination of historical facts to the concept of natural law. All the sciences that adopted the historical point of view would soon evolve into attempts to discover the laws that determined evolution, and anthropology was not, in that sense, an exception. ${ }^{54}$ Boas did not shy away, however,

5I Franz Boas, Antropologia Cultural (Rio de Janeiro: Zahar, 2004 [I896]), 29, 3I-32.

52 Ibid., 42.

53 Lévi-Strauss, Antropologia Estrutural, 310.

54 Franz Boas, A formaçâo da antropologia americana, I883-I9II: Antologia (Rio de Janeiro: Contraponto/Editora UFRJ, 2004), 44. 
from admitting that anthropology owes its existence to the stimulus provided by those scholars and the conclusions they reached, but, at the same time, he exhorted us to not overestimate the influence of their bold generalizations. .5

\section{Afterword}

Kevin B. Anderson readdressed, ${ }^{56}$ albeit much later than Lawrence Krader, ${ }^{57}$ the notebooks of Karl Marx, also called "annotations of Marx, « "ethnological notebooks, " and "notebooks of citations, « in which Marx summarized passages of books that he was studying, among which was Ancient Society by Lewis Morgan. These notebooks (to which Engels would not do justice) show him as a subtle and dialectical reader at a moment in which he seemed to be turning towards "new directions, " towards non-Western societies, which would give rise to new theoretical dislocations..$^{88}$

Certain aspects emphasized by Anderson clarify the motivations behind Marx's interest in Morgan and, above all, in the relevance of non-Western, pre-capitalist societies in order to enhance their perception through a comparison of social forms in order to reorient his thoughts on fundamental themes - such as history and the relationship between complementarity and Western and non-Western social

55 Ibid., 45.

56 Kevin B. Anderson, Marx at the Margins: On Nationalism, Ethnicity and Non-Western Societies (Chicago: University of Chicago Press, 20II); Kevin B. Anderson, Marx nas Margens: Nacionalismo, Etnia e Sociedades Não Ocidentais (São Paulo: Boitempo, 2019).

57 Lawrence Krader, The Ethnological Notebooks of Karl Marx (Amsterdam: Internationaal Instituut voor Sociale Geschiedenis, 1974).

58 Societies that had been the object of colonization (India, Indonesia, Algeria, etc.); societies located outside the developing global capitalist system (Poland, Russia, China, etc.); and societies that were included in that system (the United States and Ireland). 
formations - for the unleashing of revolutionary developments. This is the direction of this brief afterword.

Marx's position in favor of differentiated examinations of European and Asian history, and contrary to the mere transference of concepts of social structure originating in the European model to non-Western societies, already suggested that he was in the process of an inflection that would move him away from the unilinear perspective expressed in the Communist Manifesto (and which would make him adopt a multilinear perspective). 59

For this inflection, the notes of Maxim Kovalevski (a Russian sociologist and jurist), Lewis Morgan (on the American Indians) and Robert Sewell (a colonial official in India) may be determinant. Thanks to the former two, Marx came to admit that Indian society had a history, and the lines of castes that he saw in 1853 as "unsurmountable barriers that prevented social cohesion in the face of foreign invasion « became, by 1879 , something that amazed him due to their porosity. The supposition of an »invincible march of great historical forces « gave way to the contingent character of conquests, like those of the Muslim and British conquests in India. ${ }^{60}$

Marx's anti-colonialist position also emerges in his late writings and notes, ${ }^{61}$ either when taking the side of the colonized by suppressing the excerpts of Sewell portraying the British conquest as a heroic struggle against Asiatic barbarism, or when reporting the death by suffocation of Ioo British soldiers int the "Black Hole of Calcutta", or when he highlighted the transformation of ancient forms of property into unrestricted private property through the voracious forms of

59 Anderson, Marx nas Margens, $3 \mathrm{I2}$.

60 Ibid., 315-316.

6I For Anderson, Marx's anti-colonialist side became more pronounced in the years 1856-I857 through his articles in the New York Tribune. He supported the Chinese resistance against the British during the Second Opium War and the revolt of the Sepoys in northern India during 1857-1859. It was during this period that some of his new thoughts on India were incorporated into the Grundrisse (1857-1858), as well as his multilinear theory of history. Anderson, Marx nas Margens, 348. 
British capitalism. ${ }^{62}$ He supported the Polish uprising of 1863 , judged as fundamental for the labor and socialist movements, and he alerted the First International to the possibility that the denial of political and social rights to emancipated slaves in the United States would precipitate a bloodbath in the country. ${ }^{63} \mathrm{He}$ also wrote notes about the colonial system of repartimiento in Spanish America, where Amerindians were hunted down if the supply of agricultural labor declined. ${ }^{64} \mathrm{He}$ also commented on the system of encomiendas, which imposed heavy communal taxes that led to the flight and suicide of many Amerindians. ${ }^{65}$

Kovalevski's notes about Algeria were concerned with communal forms of property in the pre-colonial and colonial periods, whose strength was prevalent in the Maghreb region. The French National Assembly of 1873 tried to disassemble the foundations of communal property, convinced that the breakdown of the connection between the Arabs and the land would be the only way to prevent an anti-colonial revolt. ${ }^{66}$

The persistence of these communal structures would lead Marx to interpret them, preliminarily, as a potential source of resistance to capital, and, later, as a source of revolution when impelled by an "external subjective factor, «i. e. in association with a self-conscious and organized working-class movement. ${ }^{67}$

In his last writing on Russia, Marx would move away from the "model of implicitly unilinear development " when he admitted the possibility that non-capitalist societies may transition directly to socialism from autonomous communal structures. However, the condition for this to happen, as Marx and Engels state in the preface to the I882 edition of the Manifesto (which was, incidentally, Marx’s last

\footnotetext{
62 Ibid., 319.

63 Ibid., 225 .

64 Ibid.

65 Ibid., 216.

66 Ibid., 323-324.

67 Ibid., 34I.
} 
publication), would be through the association of communal structures with social sectors of the developed West. ${ }^{68}$ Similarly, any new system could emerge in the context of a wider social transformation involving the Western working class. ${ }^{69}$ It would be possible, then, for non-Westerners to share »the fruits of Western modernity.»

Translated by Gilmar Visoni-Alonzo

\section{Works Cited}

Anderson, Kevin B. Marx at the Margins: On Nationalism, Ethnicity and Non-Western Societies. Chicago: University of Chicago Press, $201 \mathrm{I}$.

Anderson, Kevin B. Marx nas Margens: Nacionalismo, Etnia e Sociedades Não Ocidentais. São Paulo: Boitempo, 2019.

Boas, Franz. Antropologia Cultural. Rio de Janeiro: Zahar, 2004 [1896].

Boas, Franz. A formação da antropologia americana, I883-I9II: Antologia. Organização e introdução de George W. Stocking Jr. Rio de Janeiro: Contraponto/Editora UFRJ, 2004.

Chesneaux, Jean. "O Modo de Produção Asiático: Algumas Perspectivas de Pesquisa.« In O Modo de Produção Asiático, edited by Centro de Estudos e de Pesquisas Marxistas (C. E. R. M.). Lisbon: Seara Nova, 1974.

Engels, Friedrich. A Origem da Família, da Propriedade e do Estado. Lisbon: Presença.

Forde, Daryll. "Doble Filiación entre los Yakö.«In Sistemas Africanos de Parentesco y Matrimonio, edited by Alfred Reginald Radcliffe-Brown and Daryll Forde. Barcelona: Editorial Anagrama, I982 [1950].

Godelier, Maurice. "A noção de modo de produção asiático e os esquemas marxistas de evolução das sociedades. "In O Modo de Produção Asiático, edited by Centro de Estudos e de Pesquisas Marxistas (C.E. R. M.). Lisbon: Seara Nova, 1974 .

Korsch, Karl. Marxismo e Filosofia. Porto: Ediçóes Afrontamento, 1966.

68 Ibid., 328.

69 Ibid., 34I-342. 
Krader, Lawrence. The Ethnological Notebooks of Karl Marx. Assen: Van Gorcum, I974.

Krader, Lawrence. The Ethnological Notebooks of Karl Marx. Amsterdam: Internationaal Instituut voor Sociale Geschiedenis, I974.

Kuper, Adam. The Invention of Primitive Society. London, Routledge, 1988.

Lévi-Strauss, Claude. Antropologia Estrutural. Rio de Janeiro: Tempo Brasileiro, I970.

Lévi-Strauss, Claude. As Estruturas Elementares do Parentesco. Petrópolis: Paz e Terra; São Paulo: EDUSP, 1976.

Marx, Karl. Elementos Fundamentales para la Critica de la Economía Politica (Grundisse). Madrid: Siglo XXI, I857-I858.

Morgan, Lewis Henry. Systems of Consanguinity and Affinity of the Human Family. Washington, DC: Smithsonian Contributions of Knowledge, I87I.

Morgan, Lewis Henry. A Sociedade Primitiva, Vol. I. Lisbon: Presença; São Paulo: Martins Fontes, 1976.

Morgan, Lewis Henry. A Sociedade Primitiva, Vol. II. Lisbon: Presença; São Paulo: Martins Fontes, 1978.

Radcliffe-Brown, Alfred Reginald. „O Método Comparativo em Antropologia." In Radcliffe-Brown: Antropologia, edited by J. C. Melatti. São Paulo: Ática, I978.

Radcliffe-Brown, Alfred Reginald. "Introducción."In Sistemas Africanos de Parentesco y Casamento, edited by Alfred Reginald Radcliffe-Brown and Daryll Forde. Barcelona: Editorial Anagrama, 1982.

Rubel, Maximilien. Karl Marx: Essai de biographie intellectuelle. Paris, 1957. 



\title{
Friedrich Engels's Philosophy of Nature
}

\author{
An Interpretation of the Concept \\ of the Dialectics of Nature ${ }^{1}$
}

Gottfried Schweiger

"Marx and I were pretty well the only people to rescue conscious dialectics from German idealist philosophy and apply it in the materialist conception of nature and history. $\aleph^{2}$

It was due to (unfortunate) external circumstances, including in particular the death of Karl Marx and the need to finish and edit his work on political economy, that Friedrich Engels never found the time to flesh out his philosophy of nature and that he was not able to explicate the mentioned rescuer of dialectics and its application with regard to the natural world. Engels's Dialectics of Nature was only left as a fragment, which complicates its interpretation and leaves many questions open. ${ }^{3}$ His other work that deals with

I This is a revised version of a German text that was published almost ten years ago. I did not have time to incorporate recent literature on Engels, in particular Kaan Kangal's recent and thoughtful study Friedrich Engels and the Dialectics of Nature (Basingstoke: Palgrave Macmillan, 2020).

2 Karl Marx and Friedrich Engels, "Anti-Dühring, " in Collected Works, vol. 25 (1987), II. I will cite Marx and Engels and thereafter provide the volume/page number. I will also always provide the original German text. "Marx und ich waren wohl ziemlich die einzigen, die aus der deutschen idealistischen Philosophie die bewußte Dialektik in die materialistische Auffassung der Natur und Geschichte hinübergerettet hatten.«Karl Marx and Friedrich Engels, Werke, edited by the Institut für Marxismus-Leninismus beim Zentralkomitee der SED (Berlin 1956-) [= $M E W]$, 20: 10 .

3 The origins and the history of Engels's Dialectics of Nature are explored in Anneliese Griese, „Engels's >Dialektik der Natur`. Theoretische Konzeption und philosophiehistorische Auseinandersetzung, " Deutsche Zeitschrift für Philosophie 29, no. 6 (1981): 613-628; Anneliese Griese and Gerd Pawlzig, „Friedrich Engels und Charles Darwin, in Dialektik s: Darwin und die Evolutionstheorie, 
questions of the natural sciences and nature is Anti-Dühring, a polemic against Eugen Dühring and his "revolution in science." As a polemic, this work should not be misread as systematic treatise and is no substitute for what the Dialectics of Nature should have been, other than that remarks about a dialectics of nature and the natural sciences are scattered throughout the work. In this chapter I will, nonetheless, try to explicate Engels's concept of a philosophy of nature, but not without also acknowledging the shortcomings and missteps in the existing fragments and texts. I will focus on two questions. First, what is Engels's concept of a philosophy of nature, and what should its relation with the natural sciences be? Second, what is the relation of Engels's concept of a philosophy of nature to the one of Hegel, where is Engels different from Hegel, and where are there certain similarities?

Engels develops his philosophy of nature as a necessary addition to Marx's political economy, without which the project of historical and dialectical materialism would be incomplete. There are no indications that Marx did not think highly of this enterprise or that Engels would be misguided to view the dialectics of nature as complementing the dialectics of history and society. Engels was convinced that a dialectics of nature could not be done without an engagement with Hegel's philosophy, in particular his philosophy of nature. With Hegel, classical philosophy had come to its end, Marx and Engels believed, and so had the philosophy of nature. Engels was convinced that with the advent of the modern natural sciences, the whole project of a philosophy of nature had become obsolete. He wrote: »To-

ed. Hans Heinz Holz and Hans Jörg Sandkühler (Cologne: Pahl-Rugenstein, 1982), I27-I53; Anneliese Griese and Gerd Pawlzig, "Naturwissenschaft und Dialektik in der 2. Hälfte des 19. Jahrhunderts, " in Naturdialektik-Naturwissenschaft: Das Erbe der Engelsschen ,Dialektik der Natur und seine aktuelle Bedeutung für die Wissenschaftsentwicklung, ed. Manfred Buhr and Herbert Hörz (Berlin: Akademie-Verlag, 1986), 32-48; Kurt Bayertz and Wolfgang Krohn, "Engels im Kontext. Natur- und Wissenschaftsphilosophie im Zeitalter des Szientismus," in Dialektik I2: Die Dialektik und die Wissenschaften, ed. Hans Heinz Holz and Hans Jörg Sandkühler (Cologne: Pahl-Rugenstein, 1986), 66-98. 
day, when one needs to comprehend the results of natural scientific investigation only dialetically, that is, in the sense of their own interconnection, in order to arrive at a ssystem of natures sufficient for our time; when the dialectical character of this interconnection is forcing itself against their will even into the metaphysically-trained minds of the natural scientists, today natural philosophy is finally disposed of. Every attempt at resurrecting it would be not only superfluous but a step backwards. «4 Despite this programmatic retirement of a philosophy of nature, the Dialectics of Nature, which Engels himself planned and laid out in fragments, is a work of a philosophy of nature, but a philosophy of nature of a new type. I will try to explain this type here.

\section{The Natural Sciences as the Heirs of the Philosophy of Nature}

Engels shares the view that a philosophy of nature should be understood as an enterprise that tries to understand and analyze nature, its essence and laws, but from a philosophical perspective. While the natural sciences are concerned with questions relating to particular natural objects, the relations between them or particular laws of nature, a philosophy of nature has a wider aim and aims to uncover deeper truths (and also truths that are more steadfast than those of the natural sciences). Engels believes, as we can see in the quote above, that such a philosophy of nature has become obsolete because the natural

4 Marx and Engels, "Ludwig Feuerbach and the End of Classical German Philosophy, "Collected Works, vol. 26 (1987), 386. "Heute, wo man die Resultate der Naturforschung nur dialektisch, d. h. im Sinn ihres eignen Zusammenhangs aufzufassen braucht, um zu einem für unsere Zeit genügendem 'System der Natur`zu kommen, wo der dialektische Charakter dieses Gesamtzusammenhangs sich sogar den meta-physisch geschulten Köpfen der Naturforscher gegen ihren Willen aufzwingt, heute ist die Naturphilosophie endgültig beseitigt. Jeder Versuch ihrer Widerbelebung wäre nicht nur überflüssig, er wäre ein Rückschritt." $M E W$ 2I: 296. 
sciences can take its place. But Engels includes one condition for that to happen, namely that the natural sciences become »dialectic. "In one fragment, he writes the following in this respect: "Only when natural and historical science has become imbued with dialectics will all the philosophical rubbish — other than the pure theory of thought-be superfluous, disappearing in positive science. "Engels also believes that this incorporation of dialectics into the natural sciences is something scientists have to do themselves and which they are forced to do if they want to continue to make progress. For him, empirical research alone is not sufficient to understand nature, but they need sufficient and better theories to explain the empirical knowledge they gather. Nature itself is dialectical for Engels, and if the natural sciences want to better understand nature, they will have to become dialectical. He writes in the Anti-Dühring: "Empirical natural science has accumulated such a tremendous mass of positive material for knowledge that the necessity of classifying it in each separate field of investigation systematically and in accordance with its inner inter-connection has become absolutely imperative. It is becoming equally imperative to bring the individual spheres of knowledge into the correct connection with one another. In doing so, however, natural science enters the field of theory and here the methods of empiricism will not work, here only theoretical thinking can be of assistance. « ${ }^{6}$ And for Engels, this "theoretical thinking" is dialectical, because only dialectics can explain nature and natural processes and developments. He writes:

$5 \quad$ Marx and Engels, "Dialectics of Nature, Collected Works, vol. 25 (1987), 49I. "Erst wenn die Natur- und Geisteswissenschaften die Dialektik in sich aufgenommen, wird all der philosophische Kram—außer der Lehre vom reinen Denken—überflüssig, verschwindet in der positiven Wissenschaft.« $M E W$ 2I: 296.

6 Marx and Engels, Collected Works, vol. 25, 338. "Die empirische Naturforschung hat eine so ungeheure Masse von positiven Erkenntnisstoff angehäuft, daß die Notwendigkeit, ihn auf jedem einzelnen Untersuchungsgebiet systematisch und nach seinem inneren Zusammenhang zu ordnen, schlechthin unabweisbar geworden ist. Ebenso unabweisbar wird es, die einzelnen Erkenntnisgebiete unter sich in den richtigen Zusammenhang zu bringen. Damit aber begibt sich die Naturwissenschaft auf das theoretische Gebiet, und hier versagen die Methoden der Empirie, hier kann nur das theoretische Denken helfen." $M E W$ 20: 330. 
"But it is precisely dialectics that constitutes the most important form of thinking for present-day natural science, for it alone offers the analogue for, and thereby the method of explaining, the evolutionary processes occurring in nature, inter-connections in general, and transitions from one field of investigation to another. « Engels acknowledges in this passage, and throughout his writings, a "reflection theory" ("Widerspiegelungstheorie") of knowledge and truth, which has its roots in Aristotle and was further explored and canonized in classical and orthodox Marxism, for example by Lenin. Knowledge, according to this theory, is constituted by thinking and reflecting on the outside world. Because nature and thinking are both dialectical, knowledge is only possible. Thinking represents "subjective dialectics, « and nature, as well as everything else existing outside the mind, represents "objective dialectics. ${ }^{8}$ Based on these epistemological and ontological premises, Engels believes that the natural sciences will themselves incorporate dialectical thinking as soon as they want to make further progress. Herbert Hörz called this the "objective force" of dialectics, which compels the natural sciences to become dialectical. ${ }^{9}$ Philoso-

7 Marx and Engels, Collected Works, vol. 25, 362. "Grade die Dialektik ist aber für die Naturwissenschaft die wichtigste Denkform, weil sie allein das Analogon und damit die Erklärungsmethode bietet für die in der Natur vorkommenden Entwicklungsprozesse, für die Zusammenhänge im ganzen und großen, für die Übergänge von einem Untersuchungsgebiet zum anderen.« $M E W$ 20: 330-33I.

8 "Dialectics, so-called objective dialectics, prevails throughout nature, and socalled subjective dialectics, dialectical thought, is only the reflection of the motion through opposites which asserts itself everywhere in nature, and which by the continual conflict of the opposites and their final passage into one another, or into higher forms, determines the life of nature." Marx and Engels, Collected Works, vol. 25, 492. "Die Dialektik, die sog. objektive, herrscht in der ganzen Natur, und die sog. subjektive Dialektik, das dialektische Denken, ist nur Reflex der in der Natur sich überall geltend machenden Bewegung in Gegensätzen, die durch ihren fortwährenden Widerstreit und ihr schließliches Aufgehen ineinander, resp. in höhere Formen, eben das Leben der Natur bedingen. "MEW 20: 48I.

9 Herbert Hörz, "Naturdialektik und moderne Naturwissenschaft, " in Naturdialektik-Naturwissenschaft: Das Erbe der Engelsschen ,Dialektik der Natur und seine aktuelle Bedeutung für die Wissenschaftsentwicklung, ed. Manfred Buhr and Herbert Hörz (Berlin: Akademie-Verlag, 1986), II-3I. See also his magnum 
phy could help them and support that development, but in the end, they are no longer necessary in the field of knowledge about nature, its history and developments. Thus no separate enterprise of a philosophy of nature is longer needed. Engels believed that the natural sciences are already implicitly dialectal, but without being aware of that or openly acknowledging this, and throughout his writings on nature, he referred to recent discoveries and theories in the natural sciences that he believed would support his thesis. Still, Engels also put forward the thesis that the natural sciences were still dominated by non-dialectical thinking, which he called »metaphysical thinking," and which hindered its further progress.

Dialectics would help the natural sciences to overcome this. He writes in a longer passage: "One can scarcely pick up a theoretical book on natural science without getting the impression that natural scientists themselves feel how much they are dominated by this incoherence and confusion, and that the so-called philosophy now current offers them absolutely no way out. And here there really is no other way out, no possibility of achieving clarity, than by a return, in one form or another, from metaphysical to dialectical thinking. This return can take place in various ways. It can come about spontaneously, by the sheer force of the natural-scientific discoveries themselves, which refuse any longer to allow themselves to be forced into the old Procrustean bed of metaphysics. But that is a protracted, laborious process during which a tremendous amount of unnecessary friction has to be overcome. To a large extent that process is already going on, particularly in biology. It could be greatly shortened if the theoreticians in the field of natural science were to acquaint themselves more closely with dialectical philosophy in its historically existing forms. «O $^{\text {10 }}$

opus: Herbert Hörz, Marxistische Philosophie und Naturwissenschaften (Cologne: Pahl-Rugenstein, 1974).

Io Marx and Engels, Collected Works, vol. 25, 340-34I. "Man kann kaum ein theoretisches naturwissenschaftliches Buch in die Hand nehmen, ohne den Eindruck zu bekommen, daß die Naturforscher es selbst fühlen, wie sehr sie von dieser Zerfahrenheit und Verworrenheit beherrscht werden und wie ihnen die jetzt 
Engels mentions biology here because he, as well as Marx, believed that the discovery of the evolution of species and Darwin's theoretical work were the most recent and most impressive examples of dialectics in nature. The evolution of new species and its underlying "laws of nature " are dialectical, in their view. Based on these premises, a distinct philosophy of nature is no longer needed or desirable. For Engels, the scope and aim of a philosophy of nature was always to study and research nature, its laws and essence. This was no longer needed, now that the natural sciences were themselves able to do this. For him, philosophical and scientific knowledge of nature were no longer separate but one and the same if they incorporated dialectical thinking. What remains for philosophy, with respect to nature and the natural sciences, is epistemology, logics and methodology.

To sum up, Engels's thesis that the whole project of a philosophy of nature has become superfluous rests upon two distinct premises. The first premise is ontological and states that nature is dialectical, and the second is epistemological and methodological, stating that the natural sciences can and will become dialectical. Engels aims to show both throughout his writings, and the Dialectics of Nature would have been a long argument for both theses. That is the reason why the Dialectics of Nature is a work incorporating discussions about the essence of nature, the relation between philosophy and the natural sciences, and long treatments of recent discoveries and knowledge of the natural sciences, which Engels interprets in such a way that they

landläufige sog. Philosophie absolut keinen Ausweg bietet. Und hier gibt es nun einmal keinen andern Ausweg, keine Möglichkeit, zur Klahrheit zu gelangen, als die Umkehr, in einer oder anderen Form, vom metaphysischen zum dialektischen Denken. Diese Rückkehr kann auf verschiednen Weg vor sich gehen. Sie kann sich naturwüchsig durchsetzen, durch die bloße Gewalt der naturwissenschaftlichen Entdeckungen selbst, die sich nicht länger in das alte metaphysische Prokrustesbett wollen zwängen lassen. Das ist aber ein langwieriger, schwerfälliger Prozeß, bei dem eine Unmasse überflüssiger Reibung zu überwinden ist. Er ist großenteils schon im Gang, namentlich in der Biologie. Er kann sehr abgekürzt werden, wenn die theoretischen Naturforscher sich mit der dialektischen Philosophie in ihren geschichtlich vorliegenden Gestalten näher beschäftigen wollen.« $M E W 20: 332$. 
support his ontological thesis of the dialectical nature of nature. From the perspective of a present-day reader, Engels's insistence that the natural sciences should become dialectical and his ontological view that nature itself is dialectical seem quite odd and in contradiction with modern natural sciences and philosophy. Dialectics is discredited in many ways, and today the standard position towards the natural sciences is that they are not dialectical and that it is not up to philosophy to criticize them for being non-dialectical. Engels's view was different; he saw himself as an eager supporter of modern natural sciences and tried to free them from philosophy and "metaphysical thinking, " which he saw at its best in Hegel's philosophy and his philosophy of nature. But Engels was not a positivist either. He was convinced that the natural sciences needed dialectics and that they could also learn something from classical philosophy, in particular from Hegel, otherwise they would be unfree and bound to sbad philosophical assumptions and methods.

\section{Engels's and Hegel's Philosophy of Nature}

We can now discuss the relation between Engels's idea of a dialectics of nature and Hegel's philosophy of nature in more detail. However, before we do so, a few words need to be said about Hegel's philosophy of nature. ${ }^{\text {II }}$ Unfortunately, basically everything we know about this work is what is said in the Encyclopaedia of the Philosophical Sciences, since Hegel did not write a separate book on the philosophy of nature. There is not much text available in the Encyclopaedia and what is there is written in a particular style because the Encyclopaedia was intended by Hegel to be a stextbookı for his lectures; as such,

II Much has been written about Hegel's philosophy of nature and views have changed over time. While even many Hegelians rejected Hegel's philosophy of nature as pure speculation and absurd for a long time, recent work is more favorable. I provide an overiew of the debate in my book: Gottfried Schweiger, Dialektische Naturphilosophie (Frankfurt am Main: Peter Lang, 20II). 
the text leaves many details open and room for interpretation. We know that Hegel provided much more information and detailed arguments in his lectures, and he lectured on the philosophy of nature several times during his time in Berlin in the I820s. Some lectures are now available through the transcripts of students, which makes them unreliable to some extent. ${ }^{12}$ Furthermore, a lot of text is also available through the so-called "Zusätze," which were compiled by Karl Ludwig Michelet and added to some editions of the Encyclopaedia. ${ }^{13}$ The Zusätze are also not entirely reliable and are based on the transcripts of lectures as well, but Michelet did not provide the sources. Still, every interpretation of Hegel's philosophy of nature will have to draw on these sources, simply because the original text in the Encyclopaedia is insufficient and only provides the core of Hegel's thought. Hegel himself would not have argued that his text in the Encyclopaedia should count as a fully fleshed out philosophy of nature.

For Hegel, it is evident that the natural sciences cannot substitute the philosophy of nature precisely because they are not dialectical in his view. In the Zusatz to $\$ 246$ of the Encyclopaedia, he writes about physics, which stand for him for all natural sciences: "Now the inadequacy of the thought-determinations used in physics can be traced to two points which are closely bound up with each other. $(\alpha)$ The universal of physics is abstract or only formal; its determination is not immanent in it and it does not pass over into particularity. ( $\beta$ ) The determinate content falls for that very reason outside the universal; and so is split into fragments, into parts which are isolated and detached from each other, devoid of any necessary connection, and it is

I2 For example, Georg W. F. Hegel, Naturphilosophie, Bd. I: Die Vorlesung von I8I9/20, ed. Manfred Gies with Karl-Heinz Ilting (Naples: Bibliopolis, I982); Georg W. F. Hegel, Vorlesung über Naturphilosophie, Berlin I823/24, ed. Gilles Marmasse, postscript by K. G. J. von Griesheim (Frankfurt am Main: Peter Lang, 2000).

I3 Georg W. F. Hegel, Encyclopaedia of the Philosophical Sciences, Part Two (Oxford: Clarendon Press, 1970). 
just this which stamps it as only finite. $\aleph^{14}$ Only philosophy can sthink nature as it is, that is to say, dialectical. That is what Hegel tried in his philosophy of nature, and that is why most of the text is invested in doing something quite similar to Engels: Hegel interpreted findings and theories of the natural sciences with the aim to show that nature is indeed dialectical. But Hegel was not a dialectical materialist but an idealist, and thus his relation with the natural sciences is complicated. At several points in his philosophy of nature, he assumes that his philosophical enterprise needs the natural sciences to access the dialectics in nature ${ }^{15}$, while at some other points he seems to suggest that a philosophy of nature could be done entirely without reference to the natural sciences and that one could sdeducer most if not all that is philosophically important about nature from thinking alone, without the need for any empirical research. ${ }^{16}$ It is unclear how far

I4 Hegel, Encyclopaedia, \$246, Zusatz. „Das Ungenügende nun der physikalischen Denkweise läßt sich auf zwei Punkte zurückführen, die aufs engste zusammenhängen. a) Das Allgemeine der Physik ist abstrakt oder nur formell; es hat seine Bestimmungen nicht an ihm selbst oder geht nicht zur Besonderheit über. b) Der bestimmte Inhalt ist eben deswegen außer dem Allgemeinen, damit zersplittert, zerstückelt, vereinzelt, abgesondert, ohne den notwendigen Zusammenhang in ihm selbst.« Hegel, Werke (Frankfurt am Main: Suhrkamp, 1970).

I5 For example: "The Philosophy of Nature takes up the material which physics has prepared for it empirically, at the point to which physics has brought it, and reconstitutes it, so that experience is not its final warrant and base. Physics must therefore work into the hands of philosophy, in order that the latter may translate into the Notion the abstract universal transmitted to it, by showing how this universal, as an intrinsically necessary whole, proceeds from the Notion." Hegel, Encyclopaedia, \$246, Zusatz. "Die Naturphilosophie nimmt den Stoff, den die Physik ihr aus der Erfahrung bereitet, an dem Punkte auf, bis wohin ihn die Physik gebracht hat, und bildet ihn wieder um, ohne die Erfahrung als letzte Bewährung zugrunde zu legen; die Physik muss so der Philosophie in die Hände arbeiten, damit diese das ihr überlieferte verständige Allgemeine in den Begriff übersetze, indem sie zeigt, wie es als ein in sich selbst notwendiges Ganzes aus dem Begriff hervorgeht."

I6 "The relation of philosophy to the empirical sciences was discussed in the general introduction [to the Encyclopaedia]. Not only must philosophy be in agreement with our empirical knowledge of Nature, but the origin and formation of the Philosophy of Nature presupposes and is conditioned by empirical physics. 
thinking alone can provide knowledge about nature, its laws and objects, but Hegel believes that at its core nature is dialectical, which for him means that nature is developmental but not historical. Maybe it is because Hegel lived before Darwin, but history for him is reserved for human history and development in nature only happens within a particular organism; there is no evolution. So while Engels strongly believed that evolution is proof of the dialectics of nature, Hegel confines the dialectics of nature to a dialectics of the Notion or Idea. Hegel writes: »A thinking consideration must reject such nebulous, at bottom, sensuous ideas, as in particular the so-called origination, for example, of plants and animals from water, and then the origination of the more highly developed animal organisms from the lower, and so on. « ${ }^{17}$ Hegel can make this separation between Notion and Idea

However, the course of a science's origin and the preliminaries of its construction are one thing, while the science itself is another. In the latter, the former can no longer appear as the foundation of the science; here, the foundation must be the necessity of the Notion. It has already been mentioned that, in the progress of philosophical knowledge, we must not only give an account of the object as determined by its Notion, but we must also name the empirical appearance corresponding to it, and we must show that the appearance does, in fact, correspond to its Notion. However, this is not an appeal to experience in regard to the necessity of the content. « Hegel, Encyclopaedia, \$246, Zusatz. "Nicht nur muß die Philosophie mit der Naturerfahrung übereinstimmend sein, sondern Entstehung und Bildung der philosophischen Wissenschaft hat die empirische Physik zu ihrer Voraussetzung und Bedingung. Ein anderes aber ist der Gang des Entstehens und die Vorarbeiten einer Wissenschaft, ein anderes die Wissenschaft selbst; in dieser können jene nicht mehr als Grundlage erscheinen, welche hier vielmehr die Notwendigkeit des Begriffs sein soll._Es ist schon erinnert worden, daß, außerdem daß der Gegenstand nach seiner Begriffsbestimmung in dem philosophischen Gange anzugeben ist, noch weiter die empirische Erscheinung, welche derselben entspricht, namhaft zu machen und von ihr aufzuzeigen ist, daß sie jener in der Tat entspricht. Es ist dies jedoch in Beziehung auf die Notwendigkeit des Inhaltes kein Berufen auf die Erfahrung."

I7 Hegel, Encyclopaedia, \$249, Zusatz. "Solcher nebuloser, im Grunde sinnlicher Vorstellungen, wie insbesondere das sogenannte Hervorgehen z. B. der Pflanzen und Tiere aus dem Wasser und dann das Hervorgehen der entwickelteren Tierorganisationen aus den niedrigeren usw. ist, muß sich die denkende Betrachtung entschlagen. « He further explains: »It is a completely empty thought to represent species as developing successively, one after the other, in time. Chronological 
and the appearance (Erscheinung) of nature because for him, nature is the other of the idea but is still bound to it and interwoven with it. He writes in paragraph $\$ 246$ of the Encyclopaedia: "Nature has presented itself as the Idea in the form of otherness. Since therefore the Idea is the negative of itself, or is external to itself, Nature is not merely external in relation to this Idea (and to its subjective existence Spirit); the truth is rather that externality constitutes the specific character in which Nature, as Nature, exists. $\Perp^{18}$ What Hegel really means by this characterization of nature and how he understands the relation of the Notion and the Idea to nature is far from easy to grasp, which is also because several seemingly conflicting remarks are available in the Zusätze and in transcripts of his lectures, and I will leave that question open here. What is important is to understand that, for Hegel, philosophy can understand the Notion or Idea that is present in nature (in the form of its Otherness), and that is what it should do. Philosophy is able to $>$ deduce what is in nature a priori. ${ }^{19}$ Hegel writes: »None the

difference has no interest whatever for thought." Hegel, Encyclopaedia, \$249, Zusatz. "Es ist völlig leer, die Gattungen vorzustellen als sich nach und nach in der Zeit evolvierend; der Zeitunterschied hat ganz und gar kein Interesse den Gedanken."

I8 Hegel, Encyclopaedia, $\$ 246$. „Die Natur hat sich als die Idee in der Form des Andersseins ergeben. Da die Idee so als das Negative ihrer selbst oder sich äußerlich ist, so ist die Natur nicht äußerlich nur relativ gegen diese Idee (und gegen die subjektive Existenz derselben, den Geist), sondern die Äußerlichkeit macht die Bestimmung aus, in welcher sie Natur ist."

I9 That is one prominent interpretation of Hegel's method, defended, for example, by Wolfgang Neuser and Vittorio Hösle. Neuser writes: "According to Hegel, natural philosophy then proves to be philosophy in that it can specify Notions a priori. [...] The content of the specification of Notions can only be proved in the philosophical a priori deduction.« (»Nach Hegel erweist sich Naturphilosophie dann darin als Philosophie, daß sie Begriffsbestimmungen apriori angeben kann. [...] Der Inhalt der Begriffsbestimmungen kann nur in der philosophischen a priori-Deduktion erwiesen werden.") Wolfgang Neuser, "Die Naturphilosophie, " in Hegels "Enzyklopädie der philosophischen Wissenschaften" (I830): Ein Kommentar zum Grundriß, ed. Hermann Drüe et al. (Frankfurt am Main: Surhkamp, 2000), I4I-I42. Hösle even argues that such an a priori deduction of natural objects, relations and laws can produce knowledge that has not yet been discovered or proved by the natural sciences. In such a case, philosophy of 
less, Reason must have confidence in itself, confidence that in Nature the Notion speaks to the Notion and that the veritable form of the Notion which lies concealed beneath Nature's scattered and infinitely many shapes, will reveal itself to Reason. $\aleph^{20}$ Engels, on the other hand, rejects such idealist metaphysics; for him, a philosophy of nature does not reflect on any kind of Notion or Idea that exists in nature (and forms it) because there is no such thing-for Engels, nature stands alone and for itself.

Despite the ontological differences between Hegel and Engels, and also despite the fact that Engels views Hegel's philosophy of nature as obsolete and wrong in its intentions, both works show a lot of similarities in that both philosophers invest much work into interpreting the findings and theories of the natural sciences and both claim that, through this work of interpretation, they can show that nature is dialectical. They do that with different goals in mind, no less. As I showed earlier, Hegel is convinced that the natural

nature can show that such objects, relations or laws must necessarily exist, even though the natural sciences are not yet aware of them. Hösle writes: "[S]o there may be the case that the a priori working philosopher, in fact, correctly works out conceptual structures, but that these do not correspond to any empirical conception of his time, because simply the sciences have not yet discovered the reality corresponding to the conceptual structure at the time." ("[S]o kann es den Fall geben, daß der apriorisch verfahrende Realphilosoph zwar korrekt begriffliche Strukturen herausarbeitet, daß diese aber keiner empirischen Vorstellung seiner Zeit entsprechen, weil einfach die Wissenschaften zu seiner Zeit noch nicht die der begrifflichen Struktur korrespondierende Wirklichkeit entdeckt haben.«) Hegel, Encyclopaedia, $\$_{376}$, Zusatz. "Aber dessen ungeachtet muß die Vernunft das Zutrauen zu sich selbst haben, daß in der Natur der Begriff zum Begriffe spricht, und die wahrhafte Gestalt des Begriffes, die unter dem Außeinander der unendlich vielen Gestalten verborgen liegt, sich ihr zeigen wird." Right at the beginning of the philosophy of nature, Hegel makes it clear what he aims to achieve: "As the Philosophy of Nature is a comprehending [begreifende] treatment, it has as its object the same universal, but explicitly, and it considers this universal in its own immanent necessity in accordance with the self-determination of the Notion.«Hegel, Encyclopaedia, \$246. "Indem die Naturphilosophie begreifende Betrachtung ist, hat sie dasselbe Allgemeine, aber für sich zum Gegenstand und betrachtet es in seiner eigenen, immanenten Notwendigkeit nach der Selbstbestimmung des Begriffs." 
sciences will always be deficient and not be able to fully grasp the Nation or Idea in nature, while Engels is convinced that the natural sciences will make any philosophy of nature and thus also his own work superfluous as soon as they become themselves dialectical enterprises. But although Engels rejects Hegel's idea of a philosophy of nature as some kind of better natural science, the dialectics that he aims to prove is present in nature and can be acquired by the natural sciences is something he takes from Hegel. Engels writes in this respect: "It is, therefore, from the history of nature and human society that the laws of dialectics are abstracted. For they are nothing but the most general laws of these two stages of historical development, as well as of thought itself. And indeed they can be reduced in the main to three: The law of the transformation of quantity into quality and vice versa; The law of the interpenetration of opposites; The law of the negation of the negation. All three are developed by Hegel in his idealist fashion as mere laws of thought: the first, in the first part of his Logic, in the Doctrine of Being; the second fills the whole of the second and by far the most important part of his Logic, the Doctrine of Essence; finally the third figures as the fundamental law for the construction of the whole system. The mistake lies in the fact that these laws are foisted on nature and history as laws of thought, and not deduced from them. This is the source of the whole forced and often outrageous treatment; the universe, willy-nilly, has to conform to a system of thought which itself is only the product of a definite stage of development of human thought. If we turn the thing round, then everything becomes simple, and the dialectical laws that look so extremely mysterious in idealist philosophy at once become simple and clear as noonday. ${ }^{21}$

2I Marx and Engels, Collected Works, vol. 25, 356. „Es ist also die Geschichte der Natur wie der menschlichen Gesellschaft, aus der die Gesetze der Dialektik abstrahiert werden. Sie sind eben nichts andres als die allgemeinsten Gesetze dieser beiden Phasen der geschichtlichen Entwicklung sowie des Denkens selbst. Und zwar reduzieren sie sich der Hauptsache nach auf drei:

- das Gesetz des Umschlagens von Quantität in Qualität und umgekehrt; 
In this passage, Engels makes several important claims that help us to better understand his dialectics of nature. The first claim is that the laws of dialectics can be found in nature itself and that Hegel was wrong to assume that they are only laws of thought. The second claim is that the relation of nature and thought or nature and Notion is turned around, and that Engels claims that nature is foundational. Thirdly, he rejects Hegel's methodology in his philosophy of nature, which claims that it can sthink to the natural sciences. It is the other way around for Engels. The natural sciences provide proof for the truth of dialectics and that it really exists in nature, while Hegel thought of the natural sciences as unable to provide any such definitive proof. Fourthly, despite his critique of Hegel and his dismissal of his methodology and idealist philosophy, Engels was convinced that Hegel said a lot of truths about nature and the dialectics within it. He even defended Hegel against objections that assumed that his dialectics was nothing more than speculation or even plain wrong. ${ }^{22}$

- das Gesetz von der Durchdringung der Gegensätze;

- das Gesetz von der Negation der Negation.

Alle drei sind von Hegel in seiner idealistischen Weise als bloße Denkgesetze entwickelt: das erste im ersten Teil der "Logik, « in der Lehre vom Sein; das zweite füllt den ganzen zweiten und weitaus bedeutendsten Teil seiner "Logik« aus, die Lehre vom Wesen; das dritte endlich figuriert als Grundgesetz für den Aufbau des ganzen Systems. Der Fehler liegt darin, daß diese Gesetze als Denkgesetze der Natur und Geschichte aufoktroyiert, nicht aus ihnen abgeleitet werden. Daraus entsteht dann die ganze gezwungene und oft haarsträubende Konstruktion: Die Welt, sie mag wollen oder nicht, soll sich nach einem Gedankensystem einrichten, das selbst wieder nur das Produkt einer bestimmten Entwicklungsstufe des menschlichen Denkens ist. Kehren wir die Sache um, so wird alles einfach und die in der idealistischen Philosophie äußerst geheimnisvoll aussehenden dialektischen Gesetze werden sofort einfach und sonnenklar.« $M E W$ 20: 348.

22 "It must however be recalled that the natural scientists` polemic against Hegel, in so far as they at all correctly understood him, was directed solely against these two points: viz., the idealist point of departure and the arbitrary, fact-defying construction of the system. "Marx and Engels, Collected Works, vol. 25, 343. "Es ist aber daran zu erinnern, daß die naturwissenschaftliche Polemik gegen Hegel, soweit sie ihn überhaupt richtig verstanden, sich nur gegen diese beiden Punkte 


\section{Hans Heinz Holz: From Engels to Hegel and the Plan of the Dialectics of Nature}

Hans Heinz Holz provides us with one of the most sophisticated interpretations of both Hegel's and Engels's work. I want to discuss a few of his insights in his work and also where, in my view, he errs in his interpretation of the programmatic of the Dialectics of Nature. In this discussion, I also want to explore a few more of the basic tenets of Engels's concept. Holz aims to show that the Dialectics of Nature is a necessarily ontological project. He distinguishes between a philosophy of nature as the project of an interpretation of the findings of the natural sciences and a philosophy of nature that takes the place of an ontology. Ontology, for Holz, is a necessary part of the Marxist philosophical program and the dialectics of nature takes its place. ${ }^{23} \mathrm{Holz}$ specifies these two levels or domains of a dialectics of nature: "This means that a dialectics of nature unfolds on two levels: On the one hand, in that general and fundamental domain of an ontology of nature and of the regions and layers of natural being, i. e. an ontology of the forms of movement of matter and of natural history; on the other hand, in those areas of the specification of nature that are opened up by the individual natural sciences and in which statements about the particular form of dialectical processes and structures result depending directly on the respective state of the development of science and are consequently also quite clearly provisional and outdatable. $\aleph^{24}$ In

gerichtet hat: den idealistischen Ausgangspunkt und die den Tatsachen gegenüber willkürliche Konstruktion des Systems. « $M E W$ 20: 334 .

23 "In this sense, the dialectics of nature is a theory of the world's constitution of being [Seinsverfassung der Welt] and thus takes the place of metaphysics in the system of forms of knowledge and its ideological function." Hans Heinz Holz, Weltentwurf und Reflexion Versuch einer Grundlegung der Dialektik (Stuttgart: J. B. Metzler, 2005), 540. »In diesem Sinne ist die Naturdialektik eine Theorie von der Seinsverfassung der Welt und übernimmt damit die Stelle der Metaphysik im System der Wissensformen und deren weltanschauliche Funktion."

24 Holz, Weltentwurf und Reflexion, 556-557. "Das bedeutet, daß eine Dialektik der Natur sich auf zwei Ebenen entfaltet: Einmal in jenem allgemeinen und fundamentalen Bereich einer Ontologie der Natur und der Regionen und Schichten 
his view, Engels's Dialectics of Nature aimed to combine these two distinct tasks, but most of the text that he was able to finish falls under the second category and is, therefore, largely outdated today. A similar objection could be raised towards Hegel's philosophy of nature but with the difference that Engels was well aware of this, while Hegel's program of an idealistic philosophy of nature aimed to uncover undisputable and everlasting truths also in the second area, which Holz calls »the specification of nature, « which are, for Holz, only available through the natural sciences and which are fallible.

Holz believes, in contrast to Engels, as I think, that the first task of a dialectics of nature, the development of a dialectical ontology, is not bound to the natural sciences and thus not dependent on the current state of their development or particular findings. Rather, as he aims to show, the basic ontological premises of dialectics and that the natural world is dialectical can be proven independently of the natural sciences. That brings Holz's concept of a philosophy of nature closer to Hegel's. Holz bases his interpretation that Engels makes such a sharp distinction with regard to the ontological side of the Dialectics of Nature on a few remarks of Engels. For example, Engels writes that, according to his "Outline of the General Plan« of the Dialectics of Nature, it contains "dialectics as the science of universal interconnection" ("Dialektik als Wissenschaft vom Gesamzusammenhang $)^{25}$ For Holz, this »science of universal interconnection« can only be the product of philosophical "speculation, « hence ontology, not the product of an interpretation of the findings of the natural sciences. The "universal interconnection, « which in other places is translated as "totality« and which somehow better grasps its meaning,

des natürlichen Seins, also eine Ontologie der Bewegungsformen der Materie und der Naturgeschichte; zum anderen in jenen Bereichen der Spezifikation der Natur, die durch die einzelnen Naturwissenschaften erschlossen werden und in denen Aussagen über die bestimmte Form dialektischer Prozesse und Strukturen unmittelbar abhängig vom jeweiligen Stand der Wissenschaftsentwicklung auftreten und folglich auch ganz unmittelbar vorläufig und überholbar sind."

Marx and Engels, Collected Works, vol. 25, 313; MEW 20: 307. 
is for Holz not an empirical object ${ }^{26}$ in contrast to everything else that exists in nature, which are objects, and the relations between them. Thus the method of this variation of a dialectics of nature as ontology is not an interpretation of the findings of the natural sciences but a philosophical reflection on the very grounds of reality. Holz writes in this regard: "Rather, the dialectic of nature-as a philosophical theory of nature [...] is to be derived from the theory of the reflection of the objective reality through consciousness. ${ }^{27}$ And he continues: "[T] he dialectic of nature [is] to be derived from the dialectic of thought, without having to fall into a subjective-idealistic constitutional theory. ${ }^{28}$ This is, obviously, a reference to the Kantian approach, which states that ontology and epistemology are inseparable. Holz believes that a materialist dialectics of nature can be constructed starting from the epistemological premises of a theory of reflection, and he assumes that Engels's work can be interpreted in such a way to support this approach.

This interpretation of Engels is misguided for two reasons in particular. And it is a step back to Hegel, and his idea of a philosophy of nature, that Engels would not support. Firstly, Engels is quite clear that his method is not one of speculation and he does not deduce or construct the dialectics of nature starting from an ontological or epistemological idea. He uses very different notions to describe

26 Holz is very close to Hegel in this interpretation when he writes: "That the totality [Gesamtzusammenhang] is always only thought, that is, given as an idea or in the form of a metaphysical model, does not mean that it exists only as an idea (idealiter); the idea is rather the reflection of the reality of the world as totum." Holz, Weltentwurf und Reflexion, 54I, n. 3. "Daß der Gesamtzusammenhang immer nur gedacht, das heißt als Idee oder in der Form eines metaphysischen Modells gegeben ist, besagt nicht, daß er nur als Idee (idealiter) existiere; die Idee ist vielmehr die Widerspiegelung der Realität der Welt als totum."

27 Holz, Weltentwurf und Reflexion, 560. „Vielmehr ist die Naturdialektik—als philosophische Theorie der Natur [...] herzuleiten aus der Theorie von der Widerspiegelung des objektiven Seins durch das Bewußtsein."

28 Holz, Weltentwurf und Reflexion, 56I. "[D]ie Dialektik der Natur [ist] im Rückschluß aus der Dialektik des Denkens zu gewinnen, ohne dabei in eine subjektiv-idealistische Konstitutionstheorie verfallen zu müssen." 
his methods. He claims that the dialectics of nature, the dialectical laws, etc., are to be "found " (»auffinden«) in the natural sciences and their findings, that they can be "derived" (»ableiten«) or "abstracted" ("abstrabieren") from them. He is very clear that this is not a very philosophical enterprise at all, far from the speculative methods of Holz or Hegel, for that matter. I believe that Kurt Bayertz and Wolfgang Krohn, among others, interpret this correctly when they write: "This is the goal of the dialectics of nature, which according to Engels's self-understanding, however, must not be a restitution of a philosophy of nature separated from the specialized sciences, but must reconstruct the envisaged comprehensive conception of nature [Gesamtbild der Natur] from the results of the specialized sciences themselves. ${ }^{29}$ In the German Democratic Republic, and throughout orthodox Marxism, this was the mainstream interpretation of Engels and his Dialectics of Nature. Herbert Hörz, who was the main figure in the canonization of this interpretation, established the notion or concept of "generalization " ("Verallgemeinerung") to describe Engels's method. And because the Dialectics of Nature is the result of such a generalization of the findings and theories of the natural sciences, a distinct philosophy of nature, at least in the sense of Hegel or Holz, is obsolete and bourgeois. ${ }^{30}$

Secondly, Engels not only rejects the method Holz proposes but also his idea that we need something like such an ontology or »science of totality." Rather, Engels assumes that what the natural sciences can

29 Bayertz and Krohn, "Engels im Kontext, « 82. "Dies ist das Ziel der Dialektik der Natur, die dem Engelsschen Selbstverständnis nach jedoch keine Restitution einer von den Fachwissenschaften getrennten Naturphilosophie sein darf, sondern das angestrebte Gesamtbild der Natur aus den Resultaten der Fachwissenschaft selbst zu rekonstruieren hat."

30 "Marxist philosophy does not need to be supplemented by a philosophy of nature inasmuch as it is itself also the generalization of the results of the natural sciences." Herbert Hörz and Karl-Friedrich Wessel, eds., Philosophie und Naturwissenschaften (Berlin: Deutscher Verlag der Wissenschaften, 1986), 17. „Die marxistische Philosophie bedarf insofern keiner Ergänzung durch eine Naturphilosophie, als sie selbst die Verallgemeinerung auch der Ergebnisse der Naturwissenschaften ist." 
tell us about nature and the dialectics within it are sufficient: »As soon as each special science is bound to make clear its position in the great totality of things and of our knowledge of things, a special science dealing with this totality [Wissenschaft vom Gesamtzusammenhang] is superfluous. That which still survives independently of all earlier philosophy is the science of thought and its laws-formal logic and dialectics. Everything else is subsumed in the positive science of nature and history. «I $^{31}$

\section{Conclusions}

What Engels wanted to do in the Dialectics of Nature was threefold. He wanted to show that there actually is a dialectics of nature, which means that he wanted to show that the laws of dialectics are actually operating in nature. That dialectics is not just an idea and that it is not just present in human history but in everything that exists. One major insight for him in this respect was that nature is historical, that nature is ever-changing and developing. While Hegel only knows a dialectics of Notion and denies the historicity of nature, Engels was a staunch supporter of the idea of evolution. For him, evolution was a dialectical process, and the natural sciences themselves would become aware of that sooner rather than later. For Engels, there was no longer a sharp break between natural and human history; instead, they are interwoven and the latter evolved out of the former. He writes: "The whole of nature also is now merged in history, and history is only differentiated from natural history

3I Marx and Engels, Collected Works, vol. 25, 26. "Sobald an jede einzelne Wissenschaft die Forderung herantritt, über ihre Stellung im Gesamtzusammenhang der Dinge und der Kenntnis von den Dingen sich klarzuwerden, ist jede besondre Wissenschaft vom Gesamtzusammenhang überflüssig. Was von der ganzen bisherigen Philosophie dann noch selbständig bestehen bleibt, ist die Lehre vom Denken und seinen Gesetzen-die formelle Logik und die Dialektik. Alles andre geht auf in die positive Wissenschaft von Natur und Geschichte." $M E W$ I9: 207. 


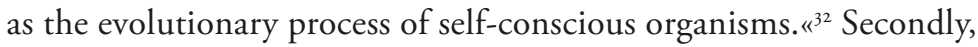
Engels aimed to show that a separate philosophy of nature, which aims to uncover universal truths about nature and which is somehow superior to the natural sciences, had become obsolete. Rather, what is necessary is to study and interpret the findings of the natural sciences, and the dialectics of nature thus becomes evident and stands for itself. For sure, Engels does not say much about how such an interpretation should be made, and his own work is not of much help either in this respect. Engels does not clearly say, for example, what should be done if some findings or theories of the natural sciences point in a different direction or outright deny dialectics. Should philosophy then criticize the natural sciences or try to prove them wrong? Engels himself does not shy away from such criticism and accuses the natural sciences from time to time in his work of being infiltrated by »bad « metaphysics and that they are themselves not able to understand that they are dialectical, even if they do not see or want that. He does that, though, with the intention to support them to become better natural sciences and to set them free from such bad metaphysics. Thirdly, and closely related to the previous point, Engels proposes a new relation between philosophy and the natural sciences, which can, at least in some points, be described as positivistic. He not only acknowledges that the natural sciences are the best available sources for knowledge about nature, but he also believes that philosophy depends entirely on them if it wants to say something meaningful about nature and natural processes. And because the natural sciences are themselves developing and the process of knowledge generation is never finished, so is the project of a dialectics of nature open-ended.

32 Marx and Engels, Collected Works, vol. 25, 516. "Jetzt auch die ganze Natur in Geschichte aufgelöst, und die Geschichte nur als Entwicklungsprozeß selbstbewußter Organismen von der Geschichte der Natur unterschieden. " $M E W$ 20: 504. 
Engels's project of a dialectics is unfinished. It was largely ignored outside of orthodox Marxism and sharply criticized, ${ }^{33}$ even by most Marxists in what were the Western countries during the Cold War. Natural scientists also largely ignored Engels's writings, and they showed basically no interest in doing what Engels hoped they would do: prove that nature is dialectical. ${ }^{34}$ That is unfortunate, because the basic premises of Engels's concept are worth re-reading and studying. Even if he is wrong, he provides the modern reader with an interesting discussion of the aims and scope of a philosophy of nature, its methods, and its relation with the natural sciences. ${ }^{35}$ The latter point is crucial for all of the modern philosophy of nature, which still is positioned somewhere between Hegel or Holz and Engels, in that it is either envisaged as an enterprise separate from the natural sciences or an enterprise closely bound to and dependent on them. Even if there is nothing like a dialectics of nature and nature does not follow the laws of dialectics, the question remains as to whether there is anything particularly philosophical to say about nature or to discover in the findings and theories of the natural sciences.

33 Helena Sheehan, Marxism and the Philosophy of Science: A Critical History (Atlantic Highlands, NJ: Humanities Press, 1993).

34 Two exceptions in the Western countries were John B.S. Haldane, The Marxist Philosophy and the Sciences (New York: Random House, 1939) and Richard Levins and Richard C. Lewontin, The Dialectical Biologist (Cambridge, MA: Harvard University Press, 1985).

35 Bonifaz Kedrow interpreted the Dialectics of Nature as a dialectics of the natural sciences. He argues that Engels was concerned with showing that the natural sciences are dialectical in themselves and that they stand in dialectical relations with each other. The dialectics of the natural sciences reflects the dialectics of nature, for example, like the transition from dead matter to living organisms is dialectical, as is the relation between chemistry and biology. Bonifaz M. Kedrow, Friedrich Engels über die Dialektik der Naturwissenschaft (Colognne: Pahl Rugenstein, 1979); Bonifaz M. Kedrow, Klassifizierung der Wissenschaften, vol. I (Cologne: Pahl-Rugenstein, 1975). 


\section{Works Cited}

Bayertz, Kurt and Wolfgang Krohn. „Engels im Kontext. Natur- und Wissenschaftsphilosophie im Zeitalter des Szientismus. "In Dialektik I2: Die Dialektik und die Wissenschaften, edited by Hans Heinz Holz and Hans Jörg Sandkühler, 66-98. Cologne: Pahl Rugenstein, 1986.

Griese, Anneliese and Gerd Pawlzig. "Friedrich Engels und Charles Darwin." In Dialektik 5: Darwin und die Evolutionstheorie, edited by Hans Heinz Holz and Hans Jörg Sandkühler, I27-I53. Cologne: Pahl-Rugenstein, I982.

— and Gerd Pawlzig. "Naturwissenschaft und Dialektik in der 2. Hälfte des I9. Jahrhunderts." In Naturdialektik_Naturwissenschaft. Das Erbe der Engelsschen "Dialektik der Natur" und seine aktuelle Bedeutung für die Wissenschaftsentwicklung, eds. Manfred Buhr and Herbert Hörz, 32-48. Berlin: Akademie-Verlag, I986.

Griese, Anneliese. „Engels's »Dialektik der Natur». Theoretische Konzeption und philosophiehisto rische Auseinandersetzung." Deutsche Zeitschrift für Philosophie 29, no. 6 (1981): 613-628.

Haldane, John B.S. The Marxist Philosophy and the Sciences. New York: Random House, I939.

Hegel, Georg W. F. Encyclopaedia of the Philosophical Sciences, Part Two. Oxford: Clarendon Press, I970.

-. Naturphilosophie, Bd. I: Die Vorlesung von I8Ig/20. Edited by Manfred Gies with Karl-Heinz Ilting. Naples: Bibliopolis, 1982.

- Vorlesung über Naturphilosophie, Berlin I823/24. Edited by Gilles Marmasse, postscript by K. G. J. von Griesheim. Frankfurt am Main: Peter Lang, 2000.

—. Werke. Frankfurt am Main: Suhrkamp, i970.

Holz, Hans Heinz. Weltentwurf und Reflexion Versuch einer Grundlegung der Dialektik. Stuttgart: J. B. Metzler, 2005.

Hörz, Herbert. Marxistische Philosophie und Naturwissenschaften. Cologne: Pahl-Rugenstein, I974.

-. "Naturdialektik und moderne Naturwissenschaft." In Naturdialektik-Naturwissenschaft. Das Erbe der Engelsschen "Dialektik der Natur" und seine aktuelle Bedeutung für die Wissenschaftsentwicklung, edited by Manfred Buhr and Herbert Hörz, II-3I. Berlin: Akademie-Verlag, 1986. 
- and Karl-Friedrich Wessel, eds. Philosophie und Naturwissenschaften. Berlin: Akademie-Verlag, 1986.

Kangal, Kaan. Friedrich Engels and the Dialectics of Nature. Basingstoke: Palgrave Macmillian, 2020.

Kedrow, Bonifaz M. Friedrich Engels über die Dialektik der Naturwissenschaft. Cologne: Pahl-Rugenstein, I979.

-. Klassifizierung der Wissenschaften, Vol. I. Colgogne: Pahl-Rugenstein, 1975.

Levins, Richard and Richard C. Lewontin. The Dialectical Biologist. Cambridge, MA, 1985 .

Marx, Karl and Friedrich Engels. »Anti-Dühring.« In Collected Works, Vol. 25. 1987.

- Werke. Edited by the Institut für Marxismus-Leninismus beim Zentralkomitee der SED. Berlin, I956-.

—. "Dialectics of Nature." In Collected Works, vol. 25, 1987.

-. "Ludwig Feuerbach and the End of Classical German Philosophy." In Collected Works, vol. 26. 1987.

Neuser, Wolfgang. "Die Naturphilosophie.«In Hegels „Enzyklopädie der philosophischen Wissenschaften "(I830). Ein Kommentar zum Grundriß, edited by Hermann Drüe et al. Frankfurt am Main: Suhrkamp, 2000.

Schweiger, Gottfried. Dialektische Naturphilosophie. Frankfurt am Main: Peter Lang, 20II.

Sheehan, Helena. Marxism and the Philosophy of Science: A Critical History. Atlantic Highlands, NJ: Humanities Press, 1993. 


\section{The Relationship between Art and Politics \\ On the Letter of Friedrich Engels \\ to Margaret Harkness ${ }^{1}$}

Henrique Wellen

\section{An Allegory on Art and Politics}

There is a famous fable about the relationship between art and politics. In the story (presented here with some alterations), a king, vain and materialistic in equal measure, vindictive and with revolutionary pretensions, made a call upon all artists to paint a portrait of him with the intention of selecting the one that portrayed him in the most realistic manner. The winner, as was the practice in that imaginary era, would also obtain a noble title. However, a specific corporal trait of the subject of the painting introduced an unusual element to the contest and made it a difficult and dangerous proposition. The king had a physical malformation on his entire left side that was impossible to leave out of the portrait. This existential question that could determine the fate of the artists led to artistic alternatives and subterfuges that produced paintings of astounding complexity. How could it be possible to portray the king faithfully without offending him, given his vain sensibilities? If, on the one hand, the painting should reflect the closest representation of reality, the painter should also be careful not to present his subject in a light where he might suffer social humiliation as a result of his physical shortcomings being exposed.

I This contribution is the translation of "Relação entre arte e política: sobre a carta de Friedrich Engels a Margaret Harkness, « Revista Espaço Acadêmico 17, no. 199 (20I7): II-2I and the editor would like to thank the author and the publisher of the original work for granting permission to publish it in the present volume. 
The first contestant, after much reflection on the nuances and implications of this paradox, resolved to depart from the second premise, since that one, being less explicit than the first, could save him from greater aggravations and would reduce the severity of his punishment. He thus opted to avoid a faithful portrait of the monarch, especially the representation of his physical defect, so by avoiding the physical problems of the king, he ended up creating a work of art that, in his view, would be superior to reality itself. When he finished his work, one could observe that the portrait looked superior to the real-life subject. In order to achieve that artistic effect, the painter used a risky subterfuge: the subject seemed to be in great physical shape, without a single defect.

The king appeared painted from the front with very bright colors and with accented shadings, portrayed with a strength that would make Hercules envious and a sagacity that would fool Ulysses himself. As expected, the first impression that the painting created in the king was one of satisfaction and plain happiness. When he saw himself represented in that way, without any defects and showing corporal strength, his face showed a mixture of pride and sadness, and, according to some witnesses, a few tears could be seen rolling down his face. There was a long pause in which the king, immersed in thoughts about the past, the present and the future, imagined himself in the physical condition depicted by the painting. How many humiliations could have been avoided! How many compliments he would have received! The painting evoked a myriad of sensations and feelings in the consciousness of the monarch, but, at the same time, it suggested the possibility of an alternative life that he was able to erase from his mind only with great effort.

Even though immersing himself in his thoughts gave him an intense sensation of joy, the return to reality, the return from that cathartic subjectivity, had a drastic impact in the most intimate corners of his being. When confronted with hard reality, he realized that it had had an even greater effect than his imagination. In reality, that painting was like a Siren's song, analogous to the temptations experi- 
enced by Ulysses, ${ }^{2}$ barely useful to outwit the people with regard to the reality that he needed to confront. And so, exhibiting an amalgam of rancor and materialistic axioms, the king made a pronouncement on the painting and the fate of its creator.

That painting — said the king — is clearly surrounded by idealistic elements and, for that reason, it represents a counter-revolutionary person. And since the painting cannot express a concrete reality, it serves as an instrument for human and social alienation. It therefore represents an attempt to counter revolutionary forces, an opiate of the people, because it induces them to fall asleep in the face of reality. And so there is no alternative but to punish the artist with the death penalty. And this is how the king dealt with the first painter and the first painting.

The second candidate felt a lot of paradoxical sensations; he felt relief because it was not his life that had been condemned to end but, on the other hand, the possibility of death was still very real for him. And here there is an important lesson about the rejection of art with idealist and subjectivist content, art intended as an escape from reality. He would not make the same mistake, and he would make an effort to portray the object with as much fidelity as possible. No arbitrary additions would be made. The work would simply reflect what is explicit and natural.

Based on these premises, the second candidate made a great effort to take away the processes and contradictions that could affect the corporal or mental expression of the king. In his painting, the king would be portrayed as a simple object, as a simple thing. If this had happened in a different period, one could say that the second artist

2 In The Odyssey, through the use of a synthesis of oral history and myths, Homer narrated the adventures of Ulysses in his attempt to return home after the Trojan War. In his journey, one of the main challenges that the hero faced was his encounter with the Sirens who tried to seduce the sailors with their song. Ulysses ordered that all members of his crew cover their ears with wax, but he would be tied to the mast of the ship so that he could listen to the Sirens and survive. See Homer, A Odisseia (São Paulo: Editora 34, 20II). 
would, in a Positivist manner, "consider everything as simple things. $\mathbb{1}^{3}$ In order not to repeat the mistake of his predecessor, he would produce an elemental copy of that which would express immediacy and the physical appearance of the king. In that way, with the king having an explicit physical deficiency, there would be no way to hide his shortcomings through idealist subterfuges. The second artist gathered his artistic abilities to produce a purely scientific reflection that would adhere to the rules of nature, just like the laws of gravity.

And so he presented the king frontally, showing not only his human nature but also representing his immutable human condition. The naturalist content was rooted in the desire to immortalize that situation as the only possible one for the king, and for that reason, he should be worshiped like a statue not only in the present but forever. The details of the second painting were so surgical that one could observe so many defects of reality itself on the body of the king and on his clothes, as well as in the surroundings of the portrait, that at first glance they were hard to identify. The painting showed several defects, but, as stated by the author of the work, they were not creations of the mind of the artist but only exact copies from that which served as the model for the painting.

When faced with this new and unexpected painting, the impact felt by the king was the opposite of the one caused by the first work. If the first idealist painter brought him feelings of happiness and satisfaction, the second painting inspired feelings of sadness and rejection. The king was stunned; at that moment, he was simultaneously subject and object, looking at the most minute corporal defects. Seeing himself portrayed in such a manner, he not only felt diminished but also experienced an unfamiliar sense of impotence. If in the first painting he could be compared to great heroes who had been able to alter the fate that the gods had imposed upon humanity, in the second paint-

3 According to Durkheim, at the beginning of the second chapter of The Rules of the Sociological Method, "The first and most fundamental rule is to consider social facts as things." Émile Durkheim, As Regras do Método Sociológico (São Paulo: Martins Fontes, 2007), I5. 
ing he seemed like a man who could hardly cope with the most insignificant challenges of life. At that moment, the king, master over the destinies of countless people, felt powerless against the world. And so the feeling that invaded him at that moment was one of resignation, of the knowledge that nothing could be done to change the human condition. This was accompanied by a sense of paralysis, just as with the first painting, but for opposite reasons. When the king saw himself idealized in the first painting, he felt as if he had escaped reality (seduced by the song of the Sirens); faced with the second image, he felt that his body was devoid of force, like a statue made of stone, as if he was experiencing the effects of having seen Medusa. ${ }^{4}$ Hoping to chase away the naturalism presented in the painting, the king spoke loudly and with even more vigor than previously. This painting, he said, is even more alienating than the first one since it lacks a sense of history and a sense of social dynamic; one needed to be extremely strong not to succumb to the sense of resignation irradiated by this work. And so, with a proud defense of his alleged historical heroic traits, the king condemned the artist to the same fate as the first one.

Given the fates of the two artists, there was great fear when a new candidate emerged. If the two artists had been executed after being accused of the opposite of what they had wanted to portray, the main concern with regard to the contest was not the benefit that one could obtain but their own survival. At this moment, after everything that had occurred, the new candidate stepped forward.

If the first painter (contrary to his intention of glorifying the king) was executed on charges of idealism, and the second candidate (who intended to portray the king in a more descriptive manner)

4 In Greek mythology, Medusa was a monster of the underworld (a Gorgon) that had the body of a woman and serpents on her head instead of hair. As related in the adventures of Perseus, Medusa had the power of turning anyone who saw her into stone. References to Gorgons precede the feats of the demi-god Perseus. They were present in Aeschylus Prometheus Chained as monsters who inhabited the plains of Quistene. See Aeschylus, "Prometeu accorentado, " in Prometeu acorrentado-Édipo Rei-Medéia by Aeschylus, Sophocles and Euripides (São Paulo: Abril cultural, I980), 39. 
received the capital penalty under charges of naturalism, why would anyone want to enter this contest? The new candidate had probably lost his senses, and that is why he drove towards his death so willingly. And even though this situation scared all those present, the king's pronouncement was an even greater surprise. After announcing that he was already devoid of the hope of finding a painting that would reflect his wishes and, therefore, was close to ending the whole process, he remarked upon how surprised he was to find a work that could bring him such artistic and political satisfaction. Not satisfied with this compliment, the king continued to extol the third artist's virtues and his ability to depict the king in such a precise aesthetic manner, without a hint of idealism or naturalism. The artist was thus deserving of all the titles and prizes promised to him. Furthermore, he would become a magistrate of the kingdom for life. For having demonstrated such competence in the aesthetic field, the painter should, according to a royal decree, assume the master chair in the field of arts and culture of the State. The general surprise from all those present (with the exception of the painter and his subject) was understandable. And everyone was curious as to the content of the portrait. What colors were used? What kinds of strokes were used? Was there a contrast of light and shadow? The use of curved lines or any other techniques typical of illusionist painting?s There was only one way to find out, but the intimidation derived from all that had happened had drained all the courage necessary to placate the collective curiosity. There was such joy and such relief when the king, extremely pleased with his portrait, invited everyone present to contemplate the masterpiece. And thus, everyone was able to appreciate the virtues presented in the painting and confirm that it was deserving of praise.

5 One of the most common expressions of Brazilian reality in the so-called illusionist paintings is found in Baroque art. These paintings create figures that enhance the spiritual and religious elements to the detriment of rational and Renaissance traits. To that end, artists used several resources, such as the juxtaposition of colors, light and shadow, drapes, and curved lines. 


\section{Friedrich Engels and the Triumph of Realism in Literature}

In the spring of 1888, Friedrich Engels, the famous German communist, sent a letter to Margaret Harkness in which he communicated some of his thoughts about one of the writer's works entitled City Girl. Harkness (who used the pseudonym John Law) was an English writer who, as a result of contacts with socialist thinkers like Eleanor Marx (Karl Marx's daughter), had made incursions into political thought and was resolved to use her literary talents in the advancement of the socialist cause.

The content of the letter did not demonstrate any analytical pretensions about aesthetics but, nevertheless, it stands as a landmark of great importance for the Marxist analysis of the relationship between art and politics. ${ }^{6}$ The letter centers on the relationship between art and politics and, especially, on the specificity of each of their qualities and the elements that the writer utilizes to avoid equalizing art and politics. The letter addresses in an essentialist and introductory manner the parameters that must be used to carry out a realistic analysis of literature and the relationship between those determinations and the political consciousness of the author.

With this argument in mind, and after congratulating Harkness for her artistic talent and courage to write such a work, Engels proceeded to analyze the quality of the book, ${ }^{7}$ defining what should be at the center of a work of art, namely its realistic character. Realism in art implies, beside truth of detail, the truthful reproduction of typical characters under typical circumstances. ${ }^{8}$ In this manner, next

6 Several authors within the Marxist tradition point to the premise of the triumph of realism as the foundation of aesthetic analysis and cite Engels's letter as the fundamental reference. Among the analyses that deal with this topic are the works of György Lukács. For a didactic synthesis of the relationship between Lukács` analysis and Engels's position, see Ranieri Carli, A estética de György Lukács e o triunfo do realismo na literature (Rio de Janeiro: EDUFRJ, 20I2).

$7 \quad$ Engels uses the term "ein kleines Kunstwerk« to describe Harkness` novel.

8 Friedrich Engels, "Engels to Margaret Harkness, " in Marx \& Engels Collected Works, Vol. 48: Letters I887-90 (London: Lawrence \& Wishart, 20I0), I67. 
to narrative faithfulness and the delineation of characters and events, there must be a "typicality" to the work.

For Engels, that is the central problem of the analyzed work, since the imbalance of that relationship marks an insufficiency on the part of the writer. On the one hand, the characters are "typical enough," but on the other, »the circumstances which surround them and make them act are not perhaps equally so. ${ }^{9}$ Engels cites the way in which the working-class characters in City Girl are lacking with regard to historical development. The tuning fork between art and the portrayed reality was out of tune since Harkness` narrative presents a working class that played a passive role and needed external help (something that was valid for conditions in England at the beginning of the $19^{\text {th }}$ century). Such conditions were very different from what English workers were experiencing during the last quarter of the $19^{\text {th }}$ century when they had become organized into labor unions and political parties. At that point, they had become an active political force. ${ }^{\circ}$

One of the elements of the character of typicality noted by Engels can be found in the precise figurative expression of the reflected moment of reality. Art cannot do without that realistic relationship with a specific reality. Such a condition would not necessarily be derived from the submission of art to history, as if the former had to portray the most perfunctory details of the latter. ${ }^{\text {II }}$ What Engels pointed out

9 Ibid.

Io An important framework in this development was the so-called "Spring of the Peoples, " a series of insurrections that spread throughout Europe in I848. This represented the gradual strengthening of the working class in the political struggle against capitalist exploitation. Providing historical, political, and documentary evidence of this movement, we have the Communist Manifesto, composed and published by Marx and Engels during this historical moment. See Karl Marx and Friedrich Engels, Manifesto do Partido Comunista (São Paulo: Cortez, I998).

II There is no consensus for this premise either among the many art critics or among the Marxist aesthetes, as we can see in the critiques of Perry Anderson on the events and character of the war between France and Russia narrated in Tolstoy's War and Peace. See Perry Anderson, "Trajetos de uma forma literária," Revista Novos Estudos 77 (March 2007): 205-220; Leo Tolstoy, Guerra e Paz (São Paulo: Cosac Naify, 20II). 
was the indispensable relationship between those two forms of representation (art and history) in order to prevent art from becoming a form of escape from reality, as well as an arbitrary crystallization of its appearance. However, one could question whether the German communist wanted to present this admonition as an attempt to defend or to aggrandize the political struggle of the workers for the construction of socialism. The answer to this conflict appears in the following comments, in which instead of pleading for the artistic writing of socialist content, he praises a very different condition: "I am far from finding fault with your not having written a socialist novel, « or, as the Germans called it, a Tendenz-roman (an engaged novel), in order to "glorify the social and political ideas of the author. «" That is to say, instead of criticizing Harkness for not writing a novel engaged in proletarian causes, the impenitent defender of the working class praises the English writer precisely for the fact that she did not introduce her own political and ideological preferences into the narrative of the novel. And just to make things even clearer, Engels adds: "The more the opinions of the author remain hidden, the better for the work of $\operatorname{art.}$ « $^{13}$

As a way of exemplifying what he defends as realism in art (and, in this case, the possibility and necessity of creating a great work of art independent of the political proclivities of the author), Engels weaves comparisons among literary works produced by artists with very different ideologies. Whereas Émile Zola was a writer known not only for his literary work but also for his socialist political engagement, Honoré de Balzac was an author whose political perspective could be qualified as not only conservative but also sympathetic towards reactionary (and aristocratic) positions. Faced with both authors, one would expect that Engels, the defender of the working class, would be more sympathetic towards Zola's work. ${ }^{14}$ However, as he admonished,

\footnotetext{
I2 Engels, "Engels to Margaret Harkness, « I67.

I3 Ibid.

I4 It is important to note that Émile Zola is the author of one of the artistic pieces of great importance in denouncing the exploitation of the workers by the capital-
} 
such a relationship should not be transposed to artistic specificity. In other words, what would serve in the effort to develop political militancy would not necessarily be useful in terms of aesthetic appreciation. It is precisely in this spirit that Engels issues his judgment on the author who is the real French master of world literature:

Balzac was politically a Legitimist; his great work is a constant elegy on the irretrievable decay of good society; his sympathies are all with the class doomed to extinction. But for all that his satire is never keener, his irony never bitterer, than when he sets in motion the very men and women with whom he sympathises most deeply-the nobles. And the only men of whom he always speaks with undisguised admiration, are his bitterest political antagonists, the republican heroes of the Cloîtred Saint-Méry, the men, who at that time (1830-36) were indeed the representatives of the popular masses. That Balzac thus was compelled to go against his own class sympathies and political prejudices, that he saw the necessity of the downfall of his favourite nobles, and described them as people deserving no better fate; and that he saw the real men of the future where, for the time being, they alone were to be found-that I consider one of the greatest triumphs of Realism, and one of the grandest features in old Balzac..$^{\text {Is }}$

In the case of that illustrious French author, the triumph of realism was expressed in the fact that his political and social beliefs did not impose limits on the typical representation of characters and events. The issue, made explicit in the quote above, is to defend the autonomy of art before politics in the sense that the specific quality of the former cannot be substantiated by the latter. That is to say, art has its own specificity and, even if political determinations are not absent, those elements only have expressive validity as part of the whole context.

ists. In Germinal, Zola exposes the ordeals experienced by coal miners oppressed under the thumb of capitalism. See Émile Zola, Germinal (São Paulo: Estação Liberdade, 20I2).

I5 Engels, „Engels to Margaret Harkness, « I68. 
When dealing with aesthetic objects, it is the specificity of art that must absorb political elements in its particularity and not the other way around.

Engels did not claim that realist artist is endowed with ideological neutrality or that he is devoid of political values or ideas, but rather that the measure of art cannot be subsumed by its political interests. Realist art does have, however, a lot of values that can, depending on the audience, produce reflective effects with political content. However, it is not these effects that measure the greatness of the work of art that produced them. Due to the need to represent reality departing from its essence, realism endorsed by defenders of communism presupposes a necessary reflection of the historical dynamic, its processes, and its immanent contradictions.

This why the search for the artistic representation of typicality in both characters and events is prohibited by the escape from reality as well as by the naturalization of reality. This is because neither artistic idealism (very present in avant-garde and subjectivist conceptions) nor artistic naturalism (which in the case analyzed by Engels is exemplified by Zola) can express the complexity of the historical dynamic in its essential movements of continuity and rupture.

In both of the analyzed cases of aesthetic figurations, history appears, to a greater or lesser degree, fractured in its processes, either by the fantastic propelling of the character towards his social possibilities or by the imagery taken from the character's immanent capacity for historical intervention. The relationships between individual and society, between subjectivity and objectivity, and between teleology and causality are such that, when one pole is hypertrophied at the expense of the other, the artistic reflection will not capture the typical essence of the characters and events in the mediation between the singular and the universal.

In both cases, a painting about reality will represent a curtailment imposed on the character, either by his awareness of the concrete possibilities that surround him or by his interventionist practice against greater obstacles. Fundamentally, what will happen in these cases are 
watertight paintings about history that do not represent the complexity of reality portrayed artistically but rather express, in a direct or indirect manner, the values, thoughts, and wishes of the artist himself.

Translated by Gilmar Visoni-Alonzo

\section{Works Cited}

Aeschylus. „Prometeu accorentado." In Aeschylus, Sophocles and Euripides, Prometeu acorrentado_Édipo Rei-Medéia. São Paulo: Abril cultural, I980.

Anderson, Perry. »Trajetos de uma forma literária.« Revista Novos Estudos 77 (2007): 205-220

Carli, Ranieri. A estética de György Lukács e o triunfo do realismo na literature. Rio de Janeiro: EDUFRJ, 2012.

Durkheim, Émile. As Regras do Método Sociológico. São Paulo: Martins Fontes, 2007.

Engels, Friedrich »Engels to Margaret Harkness. «In Marx \& Engels Collected Works, Vol. 48: Letters 1887-90. London: Lawrence \&Wishart, 2010.

Homer. A Odisseia. Sáo Paulo: Editora 34, 20 II.

Marx, Karl and Friedrich Engels. Manifesto do Partido Comunista. São Paulo: Cortez, 1998.

Tolstoy, Leo. Guerra e Paz. São Paulo: Cosac Naify, 20 II.

Zola, Émile. Germinal. São Paulo: Estação Liberdade, 2012. 


\title{
Friedrich Engels
}

\author{
From the 'Woman Questions \\ to Social Reproduction Theory
}

Vincent Streichhahn

The so-called 'woman question appeared in the context of the bourgeois revolution of I848 as a political field of conflict in Germany. It is a broad bundle of topics that were negotiated in the igth century in the political, social and literary fields. "It represented a space of political argument in which the nature, implications and origins of sexual difference might be debated, and was regarded as intensely significant for both its symbolic and its practical import. "The situation of single and married women, women's work, sexuality, as well as political rights for the female sex were among the issues discussed. On the one hand, this discourse opened up a space in which women could think about themselves differently, while on the other hand, actors of all political persuasions were forced to react to the swoman question order to become or remain hegemonic in this political field. ${ }^{2}$

The 'woman question, in this case the right to women's gainful employment or suffrage, was more than controversial in the organizations of the young German labor movement. The General German Workers Association (Allgemeiner Deutscher Arbeiterverein) under the leadership of Ferdinand Lassalle (1825-1864) openly advocated a ban on women's work, because female workers were considered competition in the job market. The Social Democratic Workers

I Lucy Delap, "The ,Woman Question ‘ and the Origins of Feminism, " in The Cambridge History of Nineteenth Century Political Thought, ed. Gareth Stedman Jones and Gregory Claeys (Cambridge: Cambridge University Press, 20II), 319.

2 On the defensive reaction against female emancipation efforts in the German Empire see Ute Planert, Antifeminismus im Kaiserreich: Diskurs, soziale Formation und politische Mentalität (Göttingen: Vandenhoeck \& Ruprecht, 1998). 
Party (Sozialdemokratische Arbeiterpartei), founded by August Bebel (1840-1913) and Wilhelm Liebknecht (1826-1900) in I869, also presented an extremely antagonistic picture. Although the first voices raised in their ranks called for the political and economic equality of the sexes, they did not prevail. The unification party conference of the Socialist Workers« Party of Germany (Sozialistische Arbeiterpartei Deutschlands) in Gotha in 1875 did not change much about this. ${ }^{3}$

It took the commitment of Bebel, who in 1879 wrote what is probably the most popular book of the German labor movement, ${ }^{4}$ namely Woman and Socialism (Die Frau und der Sozialismus), 5 to reverse the trend. Five years later followed the famous publication by Friedrich Engels (1820-1895) entitled The Origin of the Family, Private Property and the State (Der Ursprung der Familie, des Privateigentums und des Staats). ${ }^{6}$ After the repeal of the Socialist Laws (1878-1890), the 'woman question by the German Social Democratic Party, allowing the activities of the proletarian women's movement to develop increasingly within their structures in the following years. ${ }^{7}$

3 Manfred Scharinger, Proletarische Frauenbewegung. Kritische Bilanz und politische Lehren (Vienna: Arbeitsgruppe Marxismus, 2009), 28-5I.

4 In 1898 , the Berliner Illustrierte asked its readers about the most influential book of the last century. Bebel's Woman and Socialism hardly after the Conversational Encyclopaedia, the Bible and On the Origin of Species by Darwin already ranked fourth (Willy Brandt, "Hundert Jahre nach August Bebel. Ein Bestseller dient der Gleichberechtigung," in Frauen heute. Eine Bestandsaufnahme, ed. Willy Brandt (Reinbek: Rowohlt, I98I), I4.

5 August Bebel, "Die Frau und der Sozialismus," in Ausgewählte Reden und Schriften, vol. Io, ed. Internationales Institut für Sozialgeschichte Amsterdam (Munich: K. G. Sauer, 1996 [1879]).

6 Friedrich Engels, "Der Ursprung der Familie, des Privateigentums und des Staats, " in Marx-Engels-Werke (henceforth MEW), vol. 2I (Berlin: Dietz, 1962), 25-I73.

7 Richard Evans, Sozialdemokratie und Frauenemanzipation im deutschen Kaisserreich (Bonn: Dietz Verlag 1979); Elisabeth Haarmann, Schwestern zur Sonne zur Gleichheit: Die Anfänge der proletarischen Frauenbewegung (Hamburg: ErgebnisseVerlag 1985); Florence Hervé, ed., Geschichte der deutschen Frauenbewegung (Cologne: Pahl-Rugenstein 1982); Heinz Niggemann, Emanzipation zwischen Sozi- 
The present chapter pays special attention to a contextualizing appreciation of Engels's theoretical contribution to the swoman question. In addition, The Origin of the Family will be confronted with some selected feminist critiques. Finally, the social reproduction theory (SRT) will be discussed, which in a certain sense is in a line of tradition with Engels, but also overcomes his theoretical gaps and deficits in important points. The article focuses on two theses: I) on the one hand, Engels's work, alongside Bebel's book, was of great practical importance for overcoming "proletarian anti-feminism $\ll^{8}$ as a multidimensional obstacle to organization in the German working class; and 2) on the other hand, Engels left behind with The Origin of the Family and the dualism postulated therein a momentous revision of Marx's theory that brings fatal theoretical problems.

\section{Engels and The Origin of the Family as a Tacit Course Correction}

Three possible readings of Engels's book ${ }^{9}$ should be mentioned: The Origin of the Family $\mathrm{I}$ ) as the central writing of the Marxist theory of women's emancipation, which is probably the most common reading; 2) as a construction process that should give historical materialism a

alismus und Feminismus: Die sozialdemokratische Frauenbewegung im Kaiserreich (Wuppertal: Hammer, 198I); Sabine Richebächer, Uns fehlt nur eine Kleinigkeit: Deutsche proletarische Frauenbewegung (Frankfurt am Main: Fischer Taschenbuch-Verlag 1982).

8 Werner Thönnessen, Frauenemanzipation: Politik und Literatur der Deutschen Sozialdemokratie zur Frauenbewegung (1863-1933) (Frankfurt am Main: Europäische Verlangsanstalt, 1969).

9 On the history of the immediate development of the book see Editha Nagel, "Zur Geschichte der unmittelbaren Entstehung von Friedrich Engels's Schrift ,Der Ursprung der Familie, des Privateigentums und des Staates` und ihre Herausgabe in Deutschland (I884-I894), "Beiträge zur Marx-Engels-Forschung 3 (I978): I25-I4I. 
unified form ${ }^{\mathrm{Io}}$; and 3) as a tacit course correction against Bebel's publication, which in its first editions was still predominantly marked by political liberalism.

In general, The Origin of the Family is presented in the research literature as one of the early central writings of the Marxist theory of women's emancipation. This is factually correct, but it masks the actual intention of the author. That does not mean, of course, that Engels has nothing to say about the oppression of women, but because his intention was different, he deals only with certain aspects of this oppression. Overall, he says very little about the situation of women under capitalism. ${ }^{\text {II }}$ Only in the last pages of his book does he reach the phase of civilization, in which capitalism, in turn, has only a short life. The comments on this issue are therefore rather scattered throughout the book. This is no coincidence, but rather the expression of a focus of interest. In other words, it was its reception by female socialists that began a few years after publication that made it a classic on this issue. Because of the proletarian anti-feminism in the labor movement, they literally absorbed the remarks of Engels and Bebel.

Right at the beginning, it must be mentioned that the controversy surrounding Engels's book often gives the impression that the main subject is the family and everything else is an accessory. This is an unacceptable reduction. The title alone indicates that the family is merely part of a triad that still includes the state and private property. In

IO "No (male) commentator on Marxism has taken The Origin of the Family as methodologically central to Marxism and to understanding Marx« (Terrell Carver, "Marxism and Feminism: Living with Your 'Ex`, in Karl Marx and Contemporary Philosophy, ed. Andrew Chitty and Martin McIvor (New York: Palgrave Macmillan, 2009), 258).

II Working in his father's company in the textile industry, in which women played an important role, Engels was well aware of the situation of women under capitalism. In one of his early writings, Engels described the extremely precarious situation of female workers under capitalism very vividly (Friedrich Engels, "Die Lage der arbeitenden Klasse in England, "in $M E W$, vol. 2 (Berlin: Dietz 1972 [1845]), 225-506). The widespread absence of such descriptions in The Origin of the Family shows once again that it was not Engels's task to systematically explain the oppression of women under capitalism in this book. 
contrast, Engels accomplishes with his work, as he modestly informs the reader in the preface, the completion of a »legacy." We can characterize this claim as a kind of 'metapolitics that no longer depends on climbing into the arduous valley of critique in the melee, ${ }^{12}$ but rather aims to cast historical materialism into a coherent form that will shape posterity. What Engels wanted to show was the concrete application of historical materialism throughout human history. The family undoubtedly plays an important role in this, but the state and private property certainly do to no less a degree as well. It was by no means Engels's intention to develop a systematic explanation of women's oppression. With his approach, Engels (perhaps involuntarily) made a disastrous revision of Marx's theory, which will be discussed below. Nevertheless, it must be emphasized that it was an important merit of Engels to point out the historicity of the family (the state and private property) and thus deprive it of its supposed immutability. ${ }^{13}$

The reasons for Engels's decision to write the book are unfortunately in some ways still mysterious today. The creation process can only be partially reconstructed through the correspondence of Engels and some contemporaries. On February 16, I884, in a letter to Karl Kautsky (1854-1938), Engels reported Marx's enthusiasm for Lewis Henry Morgan's (I8I8-I88I) book ${ }^{14}$ : "If I had the time, I would edit the material with Marx's notes [...], but that is not to be thought of. $\aleph^{15}$

I2 Matthias Bohlender, "Marx, Engels und der 'wahre Sozialismus` oder: Die Geburt des 'historischen Materialismus` aus dem Handgemenges, " in 'Kritik im Handgemenger. Die Marx'sche Gesellschaftskritik als politischer Einsatz, ed. Matthias Bohlender et al. (Bielefeld: Transcript, 2018), 15-49.

I3 "However, an adequate political challenge to the status quo requires more than an awareness that existing social relations are not natural; it is also essential to point to the tendencies immanent to the system which point beyond it. This aspect of Engels's analysis in Origin is less successful. « Paul Blackledge, »Frederick Engels, Social Reproduction, and the Problem of a Unitary Theory of Women's Oppression, "Social Theory and Practice 44, no. 3 (2018): 3 II.

I4 Lewis H. Morgan, Ancient Society (Tucson: University of Arizona Press, 1995 [1877]).

I5 Friedrich Engels, "Engels an Karl Kautsky, I6. Februar I884, « in $M E W$, vol. 36 (Berlin: Dietz, I979), IIo. 
From late February to early March, Eduard Bernstein (I850-1932) visited Engels in London and reported: »Now, when I came over, he read to me from these manuscripts and the draft of a book based on Marx's excerpts from the American Lewis Morgan's Ancient Society, evening after evening until deep into the night. ${ }^{16}$ At the same time, the unfinished Capital volumes were waiting for completion. We must assume that the book project became increasingly important for Engels, and he almost fell into a kind of frenzy. In a letter to Friedrich Adolph Sorge (I828-1906) dated March 7, he says that Morgan "naturally rediscovered " Marx's theory of history and concluded with "communist conclusions for today. ${ }^{177}$ And on May Io, he tells Paul Lafargue (I842-I9II) that he hopes to finish the manuscript, "a very important work, ${ }^{18}$ by the end of next week.

An additional reading, that of the tacit course correction, should be suggested here. This means that Engels recognized the significance of the 'woman question` as a political field of conflict, but neither Bebel's nor Kautsky's comments satisfied him. In other words, Engels's The Origin of the Family is a political intervention written in order to maintain its own theoretical supremacy in the labor movement. Bebel's book in particular lacked a well-founded historical-materialistic foundation and Engels wanted to demonstrate his authority in interpretation. Admittedly, this reading is, in some respects, the flip side of the construction process, but sets a different accent. In the following, this reading will be checked for plausibility with some arguments.

Although Bebel and Engels corresponded with each other, the two 'woman experts of the labor movement did not seem interested in a joint substantive debate on the 'woman question. This non-relation-

I6 Quoted after Lawrence Krader, "Einleitung, " in Die ethnologischen Exzerpthefte, ed. Lawrence Krader (Frankfurt am Main: Suhrkamp, 1976), II7.

I7 Friedrich Engels, "Engels an Friedrich Adolph Sorge, 7. März I884, " in $M E W$, vol. 36 (Berlin: Dietz, 1979), I24.

I8 Friedrich Engels, „Engels an Paul Lafargue, Io. Mai I884, « in $M E W$, vol. 36 (Berlin: Dietz, 1979), I45. 
ship is initially surprising, since Engels had a lively correspondence with Kautsky in the early I880s on questions of the origins of the family and marriage, ${ }^{19}$ as well as on the distribution of his new book. ${ }^{20}$ In a letter to Engels dated May II, I882, Kautsky informed him that his own publication functioned in a certain sense as a "counterpart" to Bebel's work, since in it he focused on the early history of mankind. ${ }^{21}$ After its publication in the Stuttgarter Kosmos, a Darwinian monthly journal that was highly regarded at the time, Engels was not very convinced of its content and sharply criticized some of Kautsky's assumptions. ${ }^{22}$ In contrast, the correspondence with the thoroughbred parliamentarian Bebel was quite sober: only once did Engels mention to Bebel that he had read his remarks "with great interest" and had discovered "many good things « in them. He does not really specify this general remark: „What you say about the development of industry in Germany is particularly clear and beautiful." In the following, Engels only refers to his own position on industrial development in Germany ${ }^{23}$ and thus deliberately chooses a discursive avoidance strategy.

It seems obvious, due to the convergence in time, that Engels wanted to use his writing (not only) to intervene in a corrective manner. He met Kautsky personally in London in I88I and maintained a close relationship with him even before Kautsky's London exile (1885-1890). Therefore, Engels did not hesitate to call his friend quite harshly to order. Although he appreciated Bebel for his importance

I9 The three articles written by Karl Kautsky in I88I-I882 (»Hetärismus, " Die Raubehe und das Mutterrecht: Der Clan, and "Die Kaufehe und die patriarchale Familie«) were published together: Karl Kautsky, "Die Entstehung der Ehe und der Familie, Kosmos: Zeitschrift für einheitliche Weltanschauung auf Grund der Entwicklungslehre I2, no. 2 (I882): 190-207.

20 Kautsky wrote to Engels on July I6, I884: "Paper like that from Bebel's Woman" (Benedikt Kautsky, ed., Friedrich Engels Briefwechsel mit Karl Kautsky (Vienna:

Danubia-Verlag, 1955), I33).

2I Ibid., 57.

22 Ibid., 46-I64.

23 Friedrich Engels, "Engels an August Bebel, I8. Januar 1884, " in $M E W$, vol. 36 (Berlin: Dietz, 1979), 87. 
to the German movement, it is precisely this fact that might have prevented Engels from a direct confrontation with the ,Workers Emperor (Arbeiterkaiser) in terms of content, since he shied away from the open conflict because of the possible consequences for the organization in Germany. ${ }^{24}$ However, an open conflict was not necessary at all, since Bebel willingly allowed himself to be taught by Engels's theoretical authority. ${ }^{25}$

By shifting the focus to the historical development since the primitive societies, which Engels classifies as egalitarian societies in reference to Morgan's investigations and Marx's excerpts, he abstains from an explicit criticism of Bebel. At the same time, he elevates his own occupation to another level by identifying it as the completion of a »legacy."

It can be said that Engels's book had a considerable influence not only on Bebel's Woman and Socialism, which became more popular in Germany. However, the popularity of Bebel's book, which introduced the masses to Marxism, was by no means only due to his remarks on the 'woman question. As early as 1926, the bourgeois sociologist Hilde Lion (1893-1970) described in her study of the women's movement that " $[\mathrm{f}]$ or the intellectually vibrant proletarian, Bebel was almost always the mediator to Marx. $\aleph^{26}$ In addition, it should not be forgotten that the socially highly controversial and partly tabooed topic of sexuality certainly had a certain appeal to readers (like the authors). The importance of the utopian, i.e. the pointing out of concrete utopias, must not be overlooked either. For example, Bebel's book »was almost the only work in the Marxist literature of the time

24 Marie-Claire Hoock-Demarle, „Frauen und Frauenemanzipation in Engels Briefen, " in MEGA-Studien Journal 2 (1996): 54-65.

25 Engels turns Bebel's explanations in a historical-materialistic way. Bebel's book continued to grow in the following editions. While the first edition had just I8o pages, the final German version had 519 pages. This was due to the fact that he took over large parts of Engels's prehistory and materalistic arguments, but above all to the fact that he constantly added empirical material.

26 Hilde Lion, Zur Soziologie der Frauenbewegung: Die sozialistische und die katholische Frauenbewegung (Berlin: Herbig, 1926), 38. 
that openly met people's needs for a detailed and specific account of the socialist future. $\ll^{27}$

\section{Bebel's Influence, Engels and Political Liberalism}

Marxist theory has long been accused of gender blindness. In the meantime, research has shown that this accusation is not tenable in its entirety. Heather A. Brown shows in her systematic study Marx on Gender and the Family: A Critical Study ${ }^{28}$ how the question of gender relations and the family runs through the work of Marx and Engels. ${ }^{29}$ Although it is certainly not a dominant theme, it can nevertheless be found in the margins of many of their writings..$^{30}$ Despite this fact, they did not provide a coherent theory of women's oppression or gender relations, although some claim that for The Origin of the Family. I will show below that this is not true. However, from the early writings to the late work of Marx and Engels, there are aspects that indicate a

27 Lise Vogel, Marxismus und Frauenunterdrückung: Auf dem Weg zu einer umfassenden Theorie (Münster: Unrast Verlag, 2019 [1983]), I48.

28 Also noteworthy is her analysis of Marx's ethnographical notebooks, which have not been examined to date with regard to their position on gender, but which at the same time form the basis for Engels's The Origin of the Family. Heather A. Brown, Marx on Gender and the Family: A Critical Study (Chicago: Haymarket Books, 2013), 133-162, 176-209.

29 Brown claims to have presented the first systematic work on this question (Brown, Marx on Gender, 3). However, Manfred Scharinger published on this issue a few years earlier. This fact does not detract from the significance of Brown's work, as it sets different accents to the more historiographically oriented book from Austria. Unfortunately, the latter work, probably due to language barriers, usually gets lost in the reception. Manfred Scharinger, Geschlechterverhältnisse bei Marx und Engels: Eine kritische Auseinandersetzung (Vienna: Arbeitsgruppe Marxismus, 2007).

30 As far as I know, only Sam Stark has mentioned that Marx also dealt with the situation of women in one of the so-called "London Notebooks" (I850-I853): "But in the common descriptions of this period in the life of Karl Marx as a time of systematic studies on a critique of political economy, which was only occasionally interrupted by journalism, this issue has no clear place." Sam Stark, "Marx und die Frauenfrage, "Zeitschrift für Ideengeschichte II, no. 3 (2017): 55. 
preoccupation with gender issues and can be made fruitful in part for a gender-sensitive analysis. Moreover, and this is hardly mentioned, the two were early advocates of women's political participation in workers associations while the majority of their German comrades still vehemently opposed it. ${ }^{31}$

But precisely because of Marx's and Engels's fragmentary preoccupation with the swoman question-almost completely hidden in the excerpt notebooks ${ }^{2}$ - it was another book that focused Marxist attention on the swoman question for the first time: of course, it was August Bebel's Woman and Socialism. Female Marxists in particular oriented themselves according to these works in the following period. Clara Zetkin (1857-1933) would take the writings of Bebel and Engels as the starting point for her speech at the founding congress of the Second International in Paris in I889, which she published quite quickly as a pamphlet. Marxist theoretical works on the 'woman question ‘ in the I9th century were dominated by German authors, which is also evident from the reception of these works by foreign female socialists. ${ }^{33}$

Political activism by women was not a matter of course in the labor movement at that time. It took two authorities of the German labor movement, Bebel and Engels, to deal with the swoman question in order to partially push back sproletarian anti-feminism within Social Democracy. This was mainly supported by a misogyne journeyman culture that formed the basis of the young German labor movement. ${ }^{34}$ The industrial proletariat, as the ideal type of working

3I Judy Cox, "How Marx and Engels fought for women's liberation, «International Socialism, March 29, 2020, https://isj.org.uk/jcox-marx-engels-women-lib/.

32 It should be noted that it is often not clear what Marx intended to do with the thousands of pages of excerpts and that he did not use most of them directly for his work.

33 Eleanor Marx Aveling and Edward Aveling, "The Woman Question: From a Socialist Point of View, « Westminster Review I25 (I886): 207-222; Nadežda Konstantinovna Krupskaja, Zhenschina-rabotnica [The Woman Worker] (Munich, I90I).

34 Thomas Welskopp, "'Der Geist ächt männlichen Strebensı: Mikropolitik und Geschlechterbeziehungen im Vereinsmilieu der frühen deutschen Arbeiterbewegung, "Kurswechsel 3 (1997): 67-8I. 
class imagined by Marx, was still a minority in the workers organizations in Germany in the I86os due to the catch-up development of German capitalism. However, there were at least two other relevant approaches to Marxism: one via Christianity and one via liberalism. The latter shaped figures such as Bebel, ${ }^{35}$ Zetkin, and also Engels and Marx at different times.

In particular, the influence of liberalism on Marxist political positions and theory development is often misunderstood. In a recent essay, Cornelia Klinger refers to this fact in a semi-serious way as "a leftist melancholia about liberal democracy. ${ }^{{ }^{36}}$ Klinger thus describes an affinity that shames the actors: a close relationship between liberalism and the labor and women's movements. This close relationship results from »the thinking of the Enlightenment and the ideals of the bourgeois revolution. «7 $^{37}$ This is decisive, since Bebel's political socialization through liberalism, as well as his contacts with the bourgeois women's movement, ${ }^{38}$ according to my thesis, from the perspective of the sociology of knowledge represent a constitutional condition of the Marxist theory of women's emancipation that could not flourish in the anti-feminist milieu of the young German labor movement. ${ }^{39}$

The situation is similar for Clara Zetkin, who came into contact with the bourgeois women's movement through her mother at Au-

35 Although Bebel himself was a wood turner, he came into close contact with the liberal thinking of the time through his membership and chairmanship of the Workers` Educational Association (Gewerblicher Bildungsverein) in Leipzig.

36 Cornelia Klinger, "Weder eine bürgerliche Ehe noch eine perverse Wahlverwandtschaft: Von Liberalismus und Frauenbewegung zu Neoliberalismus und Postfeminismus, " in Liberalismus: Traditionsbestände und Gegenwartskontroversen, ed. Karsten Fischer and Sebastian Huhnholz (Baden-Baden: Nomos, 2019), 362.

37 Ibid.

38 Margrit Twellmann, Die deutsche Frauenbewegung: Ihre Anfänge und erste Entwicklung I843-I889 (Kronberg: Athenäum-Verlag, 1976), I39-I77.

39 A similar argumentation is found in Evans, who describes not only Bebel's ideas "as a reaction to the theoretical views that determined the position of bourgeois-liberal individualism in the woman question." Evans, Sozialdemokratie und Frauenemanziaption, 27. The specification made here emphasizes more strongly a sociological perspective of knowledge. 
guste Schmidt's (1833-1902) teacher training seminar in Leipzig from I874 to $1878.4^{\circ}$ At the end of the 19th century, Zetkin's theoretical views on the 'woman question « were by no means sstrictly These "developed only gradually. Her articles from the I880s show little Marxist influence and generally use arguments borrowed from either Bebel or Saint-Simon or the bourgeois-liberal theory of women's emancipation. ${ }^{41}$ After the repeal of the Socialist Laws, Zetkin became one of the outstanding leaders of the proletarian women's movement in Germany. In doing so, she earned merit less as a theoretician than as an organizer, agitator, and editor of Die Gleichheit (Equality). ${ }^{42}$

Especially in the second women's movement, Marx and Engels were accused of having largely ignored gender relations in their work. Engels and Bebel were even called "fairy-tale uncles of the woman question « by feminist activists in order to brand their supposed sexism. ${ }^{43}$ This vehemence, despite certain prejudices of Bebel and Engels regarding the gender question, fails to recognize the significance of these two books for the constitution of the proletarian women's movement in the ranks of the German Social Democrats.

Of course, there were also socialist feminists for whom the works of Engels and Bebel were indispensable reference works. ${ }^{44}$ During this

40 Clara Zetkin's mother, Josephine Eißner, maintained good relations with the two pioneers of the bourgeois women's movement, Auguste Schmidt and Louise Otto-Peters, which made it possible for her daughter to be admitted to the Leipzig teacher training seminar. Gilbert Badia, Clara Zetkin: Eine neue Biographie (Berlin: Dietz, I994), II-I4.

4I Evans, Sozialdemokratie und Frauenemanziaption, 98.

42 Mirjam Sachse, Von sweiblichen Vollmenschen und Klassenkämpferinnen: Frauengeschichte und Frauenleitbilder in der proletarischen Frauenzeitschrift, Die Gleichheit (I89I-1923) (Kassel: Universitätsbibliothek Kassel, 20II).

43 Roswitha Burgard and Gaby Karsten, Die Märchenonkel der Frauenfrage: Friedrich Engels und August Bebel (Berlin: Frauen-Selbstverlag, 1975).

44 Some activists at the time saw The Origin of the Family as the cornerstone of socialist feminism, primarily because of the fact that Engels historicized the institution of the family and, by demanding the socialization of reproductive tasks, provided important remarks for a post-capitalist organization of reproduction. 
time, they made the first attempts to make the economic writings of Marx and Engels fruitful for an analysis of women's oppression under capitalism. They rely primarily on a critical re-reading of Capital. The rich debate that developed between socialist feminists from the I970s onwards is made clear by the so-called domestic-labor debate. ${ }^{45}$ Building on Lise Vogel's work, the SRT, which is predominantly represented by Anglo-Saxon authors, emerged from this historical controversy. ${ }^{46}$ This will be discussed in more detail below. Beyond this, from the end of the 2000 onward, the first systematic attempts were made to appreciate the complete works of Marx and Engels from a gender-sensitive perspective. ${ }^{47}$

To put it all in a nutshell, Marx and Engels certainly reflected on gender relations in their writings, albeit not systematically. However, without the influence of political liberalism, the debate would probably not have been so intense. Female Marxists at the turn of the century oriented themselves mainly to Bebel's and Engels's works. After all, it was the task of the second women's movement to take on classic works, to subject them to fundamental criticism, and to develop them further. In the next section, selected feminist critiques of Engels will be presented in a concise manner to crystallize the crucial points.

\section{Selected (Socialist-)Feminist Critiques}

In this section, the criticisms of Engels by three female authors are explained in more detail, namely those of Simone de Beauvoir (1908-1986), Lise Vogel and Heather A. Brown. In The Other Sex, de

For example: Kate Millett, Sexus und Herrschaft. Die Tyrannei des Mannes in unserer Gesellschaft (Munich: Desch, I97I), I48-172.

45 For a compact presentation see Lise Vogel, "Hausarbeitsdebatte, " in Historisch-kritisches Wörterbuch, vol. I, ed. Frigga Haug (Hamburg: Argument Verlag, 2003), 540-554.

46 Tithi Bhattacharya, ed., Social Reproduction Theory: Remapping Class, Recentering Oppression (London: Pluto Books, 20I7).

47 Brown, Marx on Gender; Scharinger, Geschlechterverhältnisse. 
Beauvoir probably presented the first feminist critique of Engels. ${ }^{48}$ It comprises only a few pages but reveals fundamental logical inconsistencies. Vogel, ${ }^{49}$ on the other hand, is exemplary for a line of criticism that focuses on the dual-system topic. Brown, meanwhile, refers to Engels's economic and technical determinism, ${ }^{50}$ which leads to a one-sided framework. The criticisms are partly complementary.

As a reminder, Engels's argumentation ${ }^{51}$ is presented here in radical brevity: Engels assumed that the primitive societies of mankind were egalitarian societies. With economic and technical development, i.e. the development of productive forces, people succeeded in producing a considerable surplus over time. Private ownership of land and tools, which had previously been common property, was created. These things used to be inherited along the maternal line of inheritance (matrilineality) to the children, since only mothers knew beyond doubt who their biological children were. According to Engels, maternal rights had to make way for the paternal line of inheritance (patrilineality). Engels calls this »the world historical defeat of the female sex. ${ }^{5^{2}}$ As an institution, the family had the primary purpose of preserving property and bequeathing it to its descendants. The circle of the family became narrower with time. The women were obliged to monogamy by the men to ensure that only their own children would inherit. A central thesis of Engels is therefore that women's oppression is directly linked to the emergence of class societies. The struggle between the sexes, according to Engels, occurs

48 Simone de Beauvoir, Das andere Geschlecht: Sitte und Sexus der Frau (Hamburg: Rowohlt, I983 [1949]), 62-68.

49 Vogel, Marxismus und Frauenunterdrückung.

50 An argument that Vogel, de Beauvoir and also Michèle Barrett, as another classic feminist, have already cited in a similar way. Michèle Barrett, "Introduction, « in The Origin of the Family, Private Property and the State (Harmondsworth: Penguin Books, 1986), 7-30.

5I For a more detailed presentation see Scharinger, Geschlechterverhältnisse, 264-413; Brown, Marx on Gender, I63-175; Vogel, Marxismus und Frauenunterdrückung, II9-I45.

52 Engels, »Der Ursprung der Familie, « 6I. 
at the same time as class relations. ${ }^{53}$ Engels treats both developments as simultaneous.

De Beauvoir deals with Engels in her magnum opus, published in 1949, in the context of a tribute to historical materialism. A woman cannot be considered simply as a sex-determined organism: "the consciousness that woman has of herself is not determined by her sexuality alone: it reflects a situation that depends on the economic structure of society, a structure that expresses the degree of technological de-

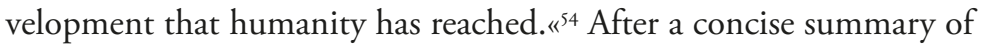
Engels's argumentation, de Beauvoir points to two central cruxes in it. The main problem is the "transition from public to private ownership, but nobody tells us how it happened. ${ }^{55}$ She notes that Engels himself admits "[w]e don't know anything about that yet. ${ }^{56}$ According to de Beauvoir, he neither provides historical evidence nor attempts an interpretation.

De Beauvoir hits the real sore spot with her second criticism: "Nor is it convincing that private property necessarily entailed the enslavement of women. Historical materialism [sic!] takes for granted facts that should be explained; it simply accepts the bond of the interior that links man with property. «" Although it is Engels and not the premises of historical materialism that makes this argument, the criticism is correct. It is logically impossible to deduce from the emergence of private property the inevitable oppression of women.

Why does oppression take place precisely along the category of gender (and race)? Why does the gendered division of labor have such serious effects? This cannot be explained simply by the end of matrilineal society due to the introduction of private poverty and patrilin-

53 "The first class opposition that appears in history coincides with the development of the antagonism between man and woman in monogamous marriage, and the first class oppression coincides with that of the female sex by the male." Ibid., 68.

54 De Beauvoir, Das andere Geschlecht, 62.

55 Ibid., 64 .

56 Engels, "Der Ursprung der Familie, « I57.

57 De Beauvoir, Das andere Geschlecht, 65. 
eality. Again, this only describes what needs to be explained. On the other hand, de Beauvoir also emphasizes the demands of motherhood, which lead to an asymmetrical relationship with men if society does not deal with them appropriately.

In Marxism and the Oppression of Women: Toward a Unitary Theory, Vogel focuses on a different theme, which Engels raises with a formulation in the foreword..$^{58}$ Interestingly, the argument was not taken up by his contemporaries, ${ }^{59}$ but only activists of the second women's movement did so. In the foreword to the I884 edition, Engels talks about two forms of production that take place separately: the production of food and that of people. ${ }^{60}$ Paradoxically, he thus laid the foundation for a dualism with serious consequences. In doing so, he drew on the manuscript of The German Ideology, ${ }^{61}$ which was not published during his or Marx's lifetimes. There, in 1846 , the two write in a very similar way: »The production of life, both of one's own in labor and of fresh life in procreation, now appears as a double relationship: on the one hand as a natural, on the other as a social relationship. ${ }^{62}$

58 Vogel, Marxismus und Frauenunterdrückung, I4I-I43.

59 "At the end of the century, socialists found the assertion in the preface concerning a duality of social reproduction sextremely remarkable, ‘ in fact salmost incomprehensible. Soviet commentators finally agreed that Engels was wrong, and that this statement could only refer to the earliest stages of human history, when humans were supposedly so much a part of nature that one could not even speak of the existence of social relations of production." Vogel, Marxismus und Frauenunterdrückung, I42.

60 "According to the materialistic conception, the determining factor in history is, in the final instance, the production and reproduction of the immediate essentials of life. This, again, is of a twofold character. On the one side, the production of the means of existence, of articles of food and clothing, dwellings, and of the tools necessary for that production; on the other side, the production of human beings themselves, the propagation of the species. The social organization under which the people of a particular historical epoch and a particular country live is determined by both kinds of production: by the stage of development of labor on the one hand and of the family on the other." Engels, "Der Ursprung der Familie, « 27-28.

6I Karl Marx and Friedrich Engels, "Die deutsche Ideologie, « in $M E W$, vol. 3 (Berlin: Dietz, 1969 [1846]), 5-530.

62 Ibid., 29. 
We can extend this point with comments from Terrell Carver, who emphasizes the importance of this shift. Engels "attempted to build on this revision an apparatus of twin-track >determination in history, involving sex-oppression and class-oppression. « $^{63}$ These "major revisions to Marx's theoretical work" had not been dealt with in detail by the interpretative tradition. Marx had already taken a different approach in the Preface to $A$ Contribution to the Critique of Political Economy. ${ }^{64}$ "The Origin of the Family [...] complicates what was otherwise a settled and (reasonably) simple story of historical rdetermination by an identifiably singular factor (production, albeit of its >means and >relations ) — as opposed to the obviously dual-factor 'production « and ‘re-production`» It was certainly not that simple and complete in Marx's writings, but Carver is correct when he remarks that "those problems have rarely, if ever, been addressed outside the feminist context, and given the airing they evidently merit. " ${ }^{65}$

Vogel argues that by using the manuscript of The German Ideology, which Engels rediscovered after Marx's death, he acquired many theoretical weaknesses of their earlier work. By postulating two separate systems of production of material life, he makes a very rudimentary distinction between natural and social phenomena, which Marx had actually overcome. It implies that the family would be an independent unit of social development. "And it is precisely this implication that has caught the imagination of contemporary socialist feminists, often tempting them into a quite cavalier reading of the Origin. " ${ }^{66}$

According to Vogel, however, he should have based his account on Marx's theory of social development. She criticizes Engels's technological determinism, which he takes over from Morgan, the uncritical adoption of the idea of the double production of The German Ideology and a utopian critique of property. "The Origin constituted a

63 Carver, "Marxism and Feminism, 258.

64 Karl Marx, »Einleitung: Zur Kritik der Politischen Ökonomie, « in $M E W$, vol. I3 (Berlin: Dietz, I97I [1857]), 615-64I.

65 Carver, "Marxism and Feminism, « 260.

66 Vogel, Marxismus und Frauenunterdrückung, I43. 
defective text whose ambiguous theoretical and political formulations nevertheless became an integral part of socialist legacy. « ${ }^{67}$

Brown aims in a similar direction to Vogel: "While de Beauvoir, Barrett, and Vogel all provide important critiques of Engels's Origin of the Family, all three tend to conflate the positions of Marx and Engels. ${ }^{68}$ However, the above should make it clear that this does not apply to Vogel. Brown argues that Marx took a more nuanced approach to this issue "since he was operating within a more dialectical framework [and was therefore] able to avoid the sort of determinism that Engels's study displays. «69 While Engels assumed, according to Brown, that the introduction of private property created the conditions of women's oppression, Marx did not believe that property was the only relevant factor. In contrast, Marx saw that the contradictions developed very early, even in communal societies. Brown quotes Raya Dunayevskaya (1910-1987) in more detail, which is reproduced here, since it is a key passage:

Nothing less than the vital question of transitions is at stake in the differences between Marx's and Engels's views. Marx was showing that it is during the transition period that you see the duality emerging to reveal the beginnings of antagonisms, whereas Engels always seems to have antagonisms only at the end, as if class society came in very nearly full blown after the communal form was destroyed and private property was established. Moreover, for Marx the dialectical development from one stage to another is related to new revolutionary upsurges, whereas Engels sees it as a unilateral progression..$^{\circ}$

The development of class and gender antagonisms is embedded by Engels in a monocausal narrative. This leads him to the assumption

67 Ibid.

68 Brown, Marx on Gender, I65.

69 Ibid.

70 Raya Dunayevskaya, Rosa Luxemburg, Women's Liberation, and Marx's Philosophy of Revolution (Atlantic Highlands, NJ: Humanities Press, I982), I80-I8I. 
that social conflicts would not have been possible at all before a relevant generation of added value. ${ }^{71}$ Referring to Marx's notes on Morgan in the notebooks, Brown explains how Marx saw the potential in early primitive societies for the development of inequalities that did not arise from private property. There, Marx recognized "the establishment of ranks - relationship of chief to mass - and the economic interests that accompanied it. "72 $^{2}$

Accordingly, Marx saw a multitude of factors for social conflicts and for the development of antagonisms. But Marx also assumed a certain power of action on the part of women, even under the most difficult conditions, which does not seem to be the case with Engels's description of the "world historical defeat of the female sex." Brown therefore sees the greatest difference between Marx and Engels in the more deterministic arguments of the latter. »Engels primarily looks to economic and technological forces to explain possibilities for change. Thus, Engels remains within a relatively deterministic and unilinear framework, whereas Marx outcomes and for much greater degree of human agency, especially for women. "73 $^{73}$

It became apparent that the criticisms of the three authors have different nuances, but complement each other in part. De Beauvoir emphasizes that Engels neglects the question of gender and treats its appearance as a cause. Vogel and Brown are united by their concern to separate Marx from Engels. While Vogel explains in abstract form that Engels's dualism does not explain the social development of the family and changes because he does not see the family as a component of social totality, Brown demonstrates it concretely. She argues that Engels sees social development too deterministically and exclusively in the field of technology and production, while Marx also considers social factors. The two views are not mutually exclusive, but complement each other.

7I Brown, Marx on Gender, I74.

72 Dunayevskaya, Rosa Luxemburg, I8I.

73 Brown, Marx on Gender, I75. 


\section{Theoretical Confusion in the Marxist Tradition}

In the following, I will concentrate on Lise Vogel's criticism of Engels's approach, which postulates two independent forms of production. Tithi Bhattacharya, currently one of the most impressive theorists in the field of SRT, succinctly sums up the void of "classical « Marxism concerning the oppression of women: "There is an unresolved tension at the heart of Marxist explanations for women's oppression under capitalism. Although there is general agreement that the bourgeois family, as the dominant kinship unit, has something to do with generating and reproducing that oppression, the exact role of the family varies among Marxists. «74 In other words, Marxist theory has long failed to theorize the family/domestic labor, which has led to an inadequate explanation of women's oppression under capitalism. Engels made a significant contribution to this with his approach.

What role does the family, as one of the core institutions for the production of life and equally importantly the production of the commodity labor, play in Engels's thinking? „Reproductive labor had social forms that organized it, such as marriage and the family; but the labor itself was seen as biological. Women who performed this labor were also naturalized, as biological beings unable to effect changes in these social orders. " 175 Engels reproduced a version of what Bhattacharya calls the dependence through sexual division of labor explanation of women's oppression. ${ }^{76}$ Bebel, too, represents a variant of this thinking, but in contrast to Engels, he locates the reasons for women's oppression on dynamics within the household and in the dependence of women on men. This rather simplistic explanation leads

74 Tithi Bhattacharya, "Liberating Women from `Political Economy`: Margaret Benston's Marxism and a Social-Reproduction Approach to Gender Oppression, « Monthly Review, January I, 2020, https://monthlyreview.org/2020/oI/oI/ liberating-women-from-political-economy/.

75 Elisabeth Armstrong, Marxist and Socialist Feminism (Northampton, MA: Smith College, Faculty Publications).

76 Bhattacharya, »Liberating Women from >Political Economy»"» 
to the fact that Bebel, especially in the first editions of his book, barely manages to go beyond bourgeois-liberal demands for equality. ${ }^{77}$ Due to his materialistic foundation, Engels is more theoretically grounded, but still deficient.

The programmatic conclusions refer to demands for equal education and the economic independence of women through wage labor. "Liberal reformers usually emphasized the emancipation-through-education route while the socialist stress was on emancipation-through-waged work, albeit with many overlaps between the two paths. ${\aleph^{78}}^{8}$ We recognize in both Bebel and Engels the heritage of the liberal tradition, which is enriched by socio-material aspects. Engels calls complete legal equality a prerequisite for true social equality of the sexes. "Then it will be plain that the first condition for the liberation of the wife is to bring the whole female sex back into public industry, and that this in turn demands the abolition of the monogamous family as the economic unit of society. «79

Engels and Bebel assumed that the liberation of women is not possible under capitalism. Both therefore linked the liberation of the female sex very closely to the fate of the working class. Thus Bebel wrote in the first edition of his book: "The woman and the worker both have in common that they have been the oppressed since time immemorial. ${ }^{80}$ According to Bebel, only the common fight could help: "The woman is also called upon not to be left behind in this struggle. $\|^{8 \mathrm{I}}$ For Bebel, there was indeed a connection between the 'woman question` and the slabor question, but in his case they do not fall into one. ${ }^{82}$ And Engels wrote in a letter to Gertrude Guillaume-Schak on July 5, I885: "In my opinion, true equality between man

77 Evans, Sozialdemokratie und Frauenemanzipation, 40-52.

78 Bhattacharya, "Liberating Women from >Political Economy`."

79 Engels, »Der Ursprung der Familie, « 76.

80 Bebel, "Die Frau und der Sozialismus, « Io.

8 I Ibid., i98.

82 "A full and complete solution of the woman question-by which I mean that women are not only equal to men by law, but are also economically free and independent of them, and as far as possible equal to them in intellectual train- 
and woman can only become a truth when the exploitation of both by capital is eliminated and private domestic work is transformed into a public industry. ${ }^{83}$ The demand to socialize private domestic work would become a central principle of the socialist strategy. In Engels's case, however, women's liberation seems to be the inevitable result of capitalist development and shows his economic determinism:

We can already see from this that to emancipate woman and make her the equal of the man is and remains an impossibility so long as the woman is shut out from social productive labor and restricted to private domestic labor. The emancipation of woman will only be possible when woman can take part in production on a large, social scale, and domestic work no longer claims anything but an insignificant amount of her time. And only now has that become possible through modern large-scale industry, which does not merely permit of the employment of female labor over a wide range, but positively demands it, while it also tends towards ending private domestic labor by changing it more and more into a public industry. ${ }^{84}$

The constant struggle against sexism-even within the working class - was not at the top of Engels's priority list. Even a relatively simple measure to reduce the double burden on women unfortunately did not come to his mind: men can also do work in the household. The sexual division of labor approach has a profound theoretical weakness. The misleading statement of Engels in his foreword certainly contributed to this confusion. In close reference to Bhattacharya, three points in particular can be criticized concerning the classical approach taken by Engels and Bebel.

ing-is just as impossible under the present social and political institutions as the solution of the labour question." Ibid., Io.

83 Friedrich Engels, »Engels an Gertrude Guillaume-Schak, 5. Juli I885, « in $M E W$, vol. 36 (Berlin: Dietz, 1979), 34I.

84 Engels, »Der Ursprung der Familie, « I58. 
I. Perhaps the most important point concerns the fact that "the division of labor explanation set up social production as being externally related to the family, as though the family merely bore the effects of social production rather than was a unit that alongside the production of commodities co-constituted those very relations making up the totality of social production under capitalism. ${ }^{85}$

2. This approach underestimates the importance that women have always had in social production. Participation in social production as the key to women's emancipation does not explain at all why women have so far failed in their liberation, even though they had a major role in work in earlier class societies. "The elevation of waged work as the path to equality, similarly, fails to explain why or how gender inequalities are consistently and reliably reproduced through the very functioning of that work. ${ }^{86}$

3. Engels failed to sufficiently theorize the family under capitalism, since he causally links the division of labor, property relations and women's oppression. The thesis of the dissolution of the family, already established in the Communist Manifesto, has, despite all the changes, not been confirmed in any way, however. Historically, on the other hand, it can be said that working families themselves held fast to the maintenance of the oppressive institution of the family, since it apparently promised them security. Even in the present day, at least in the Western hemisphere, family forms have pluralized, but by no means dissolved.

Despite all progress in the political practice of the movement evoked by the writings of Engels and Bebel, which of course still had to be fought for by women, the theoretical explanatory power of these approaches is severely limited by the points made. "If this was the totality of thinking about gender in the Marxist tradition, then we would be facing a serious problem. ${ }^{87}$ Fortunately, various socialist

85 Bhattacharya, "Liberating Women from >Political Economy^."

86 Ibid.

87 Ibid. 
feminists have pointed out in the past that this approach, formulated in The Origin of the Family, is by no means congruent with the theoretical considerations of Marx. Vogel and Brown have already been mentioned. Bhattacharya makes a similar point when she writes that the "Marxist method remains the key to understanding, and solving, the problem of gender oppression. [...] [T] heir writings on general social production contain the seeds of a far more robust, creative, and historical materialist theory of gender under capitalism. This is the social reproduction approach. ${ }^{88}$

While it was of immense importance for the common organization of women and men in the workers associations that two authorities of the labor movement dealt with the 'woman question in a progressive way, they left behind serious theoretical problems. The political consequence, therefore, is that Engels's dualism has led to confusion about the meaning of the family in the socialist tradition following him.

\section{Socialist Feminism}

In the context of the second women's movement, a debate was held which is now known as the domestic-labor debate. ${ }^{89}$ Following historical forerunners such as Mary Inman, ${ }^{90}$ Margaret Benston presented a theoretically important contribution in $1969.9{ }^{91}$ Benston's considerations are important because it is probably the first time that domestic labor was understood as an economic activity and thus located within the capitalist mode of production. What Benston did

88 Ibid.

89 Vogel, "Hausarbeitsdebatte, «540-554.

90 Mary Inman was an American communist, who argued that the reproductive labor of women should be recognized as productive work. Mary Inman, In Woman's Defense (Los Angeles: The Committee to Organize the Advancement of Women, 1940).

9I Margaret Benston, »The Political Economy of Women's Liberation, « Monthly Review 21, no. 4 (1969): 13-27. 
not yet find, however, was a consideration of what specific commodity domestic work produces. This is the (re)production of commodity labor. Finally, in the I970s, the domestic labor debater unfolded, which produced important contributions such as those of Mariarosa Dalla Costa and Selma James, ${ }^{92}$ Wally Seccombe ${ }^{93}$ and many others. "Largely unhappy with the economist focus of these earlier pieces and dual-system theory, Lise Vogel sought to expand beyond the focus on domestic labour without positing separate spheres. «94 The central concern of her approach was to overcome the dualism led by Engels and adopted by many feminists of the second women's movement and to develop a uniform theoretical framework for the analysis of women's broaden our understanding of the political economy of social reproduction. «95

\section{Social Reproduction Approach}

Vogel's approach is characterized by the attempt to examine women's oppression in the context of a feminist critique of political economy. The value-theoretical specification of the concept of reproduction can theoretically grasp the structural interlocking of the reproduction of commodity labor and the production of added value far more systematically than previous approaches, and at the same time free them from normative assumptions. Furthermore, this value-theoretical concept of reproduction can expand our understanding of class struggles, which by no means take place only in the factory but also in the public reproduction sector, such as the health and education sec-

92 Mariarosa Dalla Costa and Selma James, The Power of Women and the Subversion of the Community (Bristol: Falling Wall Press, 1972).

93 Wally Seccombe, "The Housewife and Her Labour under Capitalism, "New Left Review 83, n oppression under capitalism. "Thus, Vogel begins to o. I (1974): 3-24.

94 Brown, Marx on Gender, 69.

95 Ibid., 70. 
tors. ${ }^{96}$ Vogel developed her concept of reproduction from a feminist re-reading of the theory of value in the first volume of Marx's Capital. Ultimately, Vogel theorizes reproductive work as a component of Marx's concept of necessary work. ${ }^{97}$

In Capital, Marx refers, among other things, to the significance of gender in determining the value of labor, but explicitly excludes it from further investigation..$^{98}$ Nevertheless, his economic writings contain some important remarks on the reproduction of labor. Marx, for example, emphasizes the central importance of the consumption of labor. ${ }^{99}$ This is characterized by two sides: productive and individual consumption. In the production of goods, the workers themselves consume means of production and thus increase the value of the product. The worker thereby acts "as the moving force of capital and belongs to the capitalist." In individual consumption, on the other hand, the the worker and her/his labor belongs to her/himself and "performs vital functions outside the production process." This means the consumption of food, »the consumption of which serves to reproduce the muscles, nerves, bones, brains of existing workers and to create new workers. «100

Vogel ties in at this point: it is true that individual consumption describes an area of the daily reproduction of individual workers.

96 Ronda Kipka and Vincent Streichhahn, "Kapital gegen Leben: Plädoyer für einen politik-ökonomischen Reproduktionsbegriff," Prokla 197, no. 4 (2019): $585-590$.

97 Vogel himself does not find the extension of the necessary work entirely convincing in an essay from 2000 and was criticized for this; see Susan Ferguson and David McNally, »Capital, Labour-Power, and Gender-Relations: Introduction to the Historical Materialism Edition of Marxism and the Oppression of Women, « in Lise Vogel, Marxism and the Oppression of Women: Toward a Unitary Theory (Chicago: Haymarket Books, 2013), xvii-xl, here xxxiii.

98 Karl Marx, "Größenwechsel von Preis der Arbeitskraft und Mehrwert, « in $M E W$, vol. 23 (Berlin: Dietz, I962 [1867]), 542.

99 Karl Marx, »Lohn, Preis und Profit, « in $M E W$, vol. I6 (Berlin: Dietz, 1962 [1865]), I3I.

Ioo Karl Marx, "Der Akkumulationsprozeß des Kapitals, in $M E W$, vol. 23 (Berlin: Dietz, 1962 [1867]), 596-597. 
However, there is no systematic explanation for how this relates to people outside of the wage employment relationship (e.g. children, the sick, the elderly). Marx ignores the fact that an entire class of workers and not only the individual worker must be reproduced. Moreover, the processes of social reproduction must be organized over generations in order to ensure the maintenance of the accumulation of capital in the long term. ${ }^{\text {Ior }}$ Against the background of these considerations, Vogel develops a typology with which she distinguishes three areas of the reproduction of the labor force: I) the production of the products directly consumed by the worker, 2) the maintenance, education and care of all those outside the work process, and 3) generative reproduction (primarily childbirth, but also migration, etc.). ${ }^{102}$

Up to now, the value-theoretical definition of the concept of reproduction has not included gender relations. From a theoretical point of view, Vogel concludes, the reproduction of the labor force »is by no means bound to private kinship-based households [...]. In particular, it does not necessarily include any or all of the following components: heterosexuality, biological reproduction, family forms or generational renewal. ${ }^{103}$ Nevertheless, social reproduction cannot be thought of at present without the security of women. In order to understand how the dynamics of capital accumulation (re)produce a social-reproductive contradiction as well as modern gender (and race) relations, it is necessary, among other things, to functionally determine the social-reproductive significance of the household for capital.

What is certain is that women still do significantly more unpaid domestic labor than men and are increasingly exposed to (male) violence in their own families. "While the family is fundamental to women's oppression in capitalist society, the pivot of this oppression is not women's domestic labour for men or children, however op-

\footnotetext{
IOI Vogel, Marxismus und Frauenunterdrückung, I45.

IO2 Ibid., I88.

IO3 Lise Vogel, "Nachtrag: Hausarbeit neu gedacht, in Marxismus und Frauenunterdrückung: Aufdem Weg zu einer umfassenden Theorie (Münster: Unrast Verlag, 2019 [2000]), 259.
} 
pressive or alienating this might be. ${ }^{104}$ However, the household is undoubtedly one of the central institutions of women's oppression because it functions as a venue for the structurally contradictory relationship between reproduction and the accumulation of capital. The domestic unit receives its oppressive function through its social-reproductive function for capital. This does not mean, however, that the specific form of this oppression is deterministic and monocausal, but rather that it is permanently reproduced through processes of subjectivation. ${ }^{\text {10s }}$ The family remains tenacious because it continues to be the most practicable model for ensuring the necessary reproduction of the commodity of labor at the lowest cost. However, and this is a central point of SRT, it is not necessarily responsible for the reproduction of labor.

But why do predominantly women take over reproductive tasks? Vogel assumes that the biologically limited period of pregnancy in class societies tends to lead to a gender-specific division of labor and its institutionalization. Under capitalism, this sideally expresses itself in the form of the bourgeois nuclear family. This does not mean that women are more caring because of a supposed snature and therefore take over predominantly unpaid reproductive work. The private and domestic tasks are, however, performed according to the biological-physical facts that reproduction and breastfeeding require bodies of the rfemaler sex. ${ }^{106}$ From the perspective of the ruling class, the bearing of children tends to be cost-intensive, since potentially value-added-producing labor is withdrawn from the market during this period. At the same time, childbearing is necessary to generatively reproduce the working class. In this respect, a socially-reproductive contradiction arises between the highest possible rate of exploitation

IO4 Ferguson and McNally, „Capital, «xxv.

Ios Julia Dück und Katharina Hajek, "Intime Verhältnisser: Eine gesellschaftstheoretische Erweiterung der Debatte um soziale Reproduktion, « in Feminismus und Marxismus, ed. Alexandra Scheele und Stefanie Wöhl (Weinheim: Beltz Juventa 2018), 220-233.

Io6 Ferguson and McNally, „Capital, «xxv. 
and the long-term preservation of the commodity of labor, which unfolds the fatal dynamic that produces the androcentric gender relations that are reproduced and naturalized every day through cultural and symbolic practices. ${ }^{\text {I07 }}$

It is up to the state as $»$ ideal total capitalist ${ }^{108}$ to deal politically with this contradiction in the tension between state, market and family. The relationship between these three classical poles of welfare state research ${ }^{109}$ was applied to social reproduction by Nancy Fraser. She distinguishes three different phases of reproduction from the I9th century until today. ${ }^{\text {IIO }}$ The extent to which the processes of social reproduction are organized by the state, commodified or left within the family is the result of a variety of factors: labor requirements, economic conditions, class struggles and contingent developments. Class struggles can influence the value of the commodity labor, since it is not a fixed quantity. From a classical Marxist perspective, the workers, traditionally the industrial proletariat, can increase the value of their labor force through union wage struggles in production. However, on the one hand, this sociological determination of the working class does not go far enough but, on the other, the rate of exploitation can also be tweaked through struggles in the public reproductive sector. ${ }^{\text {III }}$

Moreover, already in Marx's work, a class is the variable result of a historical process in which one class constitutes itself in an antagonistic struggle against another class. According to Cinzia Arruzza, one of the worst political mistakes, therefore, is to want to determine what

Io7 Pierre Bourdieu, Die männliche Herrschaft (Frankfurt am Main: Suhrkamp, 2005).

I08 Friedrich Engels: „Die Entwicklung des Sozialismus von der Utopie zur Wissenschaft, in $M E W$, vol. I9 (Berlin: Dietz, 1987 [I88o]), 222.

Io9 Gøsta Esping-Andersen, The Three Worlds of Welfare Capitalism (Princeton, NJ: Princeton University Press, 1990).

IIo Nancy Fraser, "Contradictions of Capital and Care, «New Left Review Ioo (2016): 99-II7.

III Kipka and Streichhahn, »Kapital gegen Leben, « 585-590. 
is considered class struggle and what is not. ${ }^{\mathrm{II} 2}$ The feminist struggles of recent years have initiated a process of class subjectivation that has made the organized working class more colorful and feminine. The reproductive strikes carry a huge potential for class struggles to unfold, since schools and hospitals are essential for the reproduction of the whole capitalist system and, at the same time, function as crystallization points where different parts of classes meet. This potential must be used in the struggle for a society free of domination beyond exploitation and oppression.

For Vogel, as she writes in her essay from 2000, the attempt of a uniform materialistic theoretical framework is still an unfinished project. The representatives of SRT have taken up the thread of that time again. Finally, the SRT is intended to develop a "historical-materialist reading of social power relations that identifies the conditions under which race, gender, sexuality and class can be (co-)reproduced, transformed and potentially revolutionized. ${ }^{\mathrm{II3}}$ So the challenges have not diminished and are by no means solved, but many activists are working on these important issues in a promising way.

\section{Outlook}

Engels's The Origin of the Family, indissolubly linked to Bebel's work, had an immensely important meaning for the political practice of the labor movement. Bebel and Engels made it possible to partially overcome "proletarian anti-feminism" so that proletarian women-despite continuing resistance-were able to organize themselves in the ranks of the German Social Democrats after the fall of the Socialist Laws. Engels had two main reasons for publishing his book. On the

II2 Cinzia Arruzza, "From Women's Strikes to a New Class Movement: The Third Feminist Wave, "Viewpoint, December 3, 2018, https://www.viewpointmag. $\mathrm{com} / 2018 / \mathrm{I} 2 / 03 /$ from-womens-strikes-to-a-new-class-movement-the-thirdfeminist-wave/.

II3 Ferguson and McNally, "Capital, « xxxvii. 
one hand, the publication was a tacit course correction that seemed necessary to him due to the publication of Bebel's work. On the other hand, he apparently believed to have found proof of the Marxist world view in the works of Marx and Morgan. Engels was determined to present this proof to the public. It was, however, not him but the book's reception by female socialists that began a few years after its publication that made it a classic on this issue.

Nevertheless, with Engels's book and the dualism postulated therein, he left behind a momentous revision of Marx, which mainly preoccupied socialist feminists of the second women's movement. Fortunately, the approaches of Engels and Marx are not congruent on this issue. The Marxist method includes the possibility of solving the theoretical problems raised. It was Lise Vogel who made the first well-founded attempt to overcome Engels's dualism within a unitary materialist theoretical framework. But as she herself has admitted, this project is still unfinished.

To bring this project to a conclusion is the concern of many Marxist feminists who have been working on the SRT in the last decade. "Marxist feminist scholars did not simply expand the definition of sproduction to include unpaid and racialized reproductive labor as its hidden center, but asked what it revealed about capitalism as a whole." "It4 I am convinced that SRT is currently the most fruitful attempt, but it is still an immense task that is becoming increasingly urgent in the face of worsening crises of civilization. There is, however, a tradition in Marxism that we should turn to more intensively again in order to deal with these theoretical and practical challenges. Engels (and Marx), though not his writing on The Origin of the Family, is an indispensable reference point for this.

II4 Armstrong, Marxism and Socialist Feminism. 


\section{Works Cited}

Armstrong, Elisabeth. Marxist and Socialist Feminism. Northampton, MA: Smith College, Faculty Publications.

Arruzza, Cinzia. „From Women's Strikes to a New Class Movement: The Third Feminist Wave."Viewpoint, December 3, 2018. https://www.view pointmag.com/2018/12/03/from-womens-strikes-to-a-new-class-move ment-the-third-feminist-wave/.

Badia, Gilbert. Clara Zetkin: Eine neue Biographie. Berlin: Dietz, 1994.

Barrett, Michèle. »Introduction. "In The Origin of the Family, Private Property and the State. Harmondsworth: Penguin Books, 1986.

Bebel, August. "Die Frau und der Sozialismus."In Ausgewählte Reden und Schriften, vol. Io, edited by Internationales Institut für Sozialgeschichte Amsterdam. Munich: K. G. Sauer, 1996 [1879].

Benston, Margaret. »The Political Economy of Women's Liberation. "Monthly Review 21, no. 4 (1969): 13-27.

Bhattacharya, Tithi. "Liberating Women from >Political Economy: Margaret Benston's Marxism and a Social-Reproduction Approach to Gender Oppression." Monthly Review, January I, 2020. https://monthlyreview. org/2020/or/or/liberating-women-from-political-economy/.

Bhattacharya, Tithi, ed. Social Reproduction Theory: Remapping Class, Recentering Oppression. London: Pluto Books, 2017.

Blackledge, Paul. »Frederick Engels, Social Reproduction, and the Problem of a Unitary Theory of Women's Oppression." Social Theory and Practice 44, no. 3 (July 2018): 297-321.

Bohlender, Matthias. "Marx, Engels und der 'wahre Sozialismus oder: Die Geburt des historischen Materialismusı aus dem Handgemenge«" In ’Kritik im Handgemenger. Die Marx'sche Gesellschaftskritik als politischer Einsatz, edited by Matthias Bohlender et al., I5-49. Bielefeld: Transcript, 2018.

Bourdieu, Pierre. Die männliche Herrschaft. Frankfurt am Main: Suhrkamp, 2005.

Brandt, Willy. "Hundert Jahre nach August Bebel. Ein Bestseller dient der Gleichberechtigung." In Frauen heute. Eine Bestandsaufnahme, edited by Willy Brandt. Reinbek: Rowohlt, 198I.

Brown, Heather A. Marx on Gender and the Family: A Critical Study. Chicago: Haymarket Books, 20I3. 
Burgard, Roswitha and Gaby Karsten. Die Märchenonkel der Frauenfrage: Friedrich Engels und August Bebel. Berlin: Frauen-Selbstverlag, 1975.

Carver, Terrell. "Marxism and Feminism: Living with Your 'Exı." In Karl Marx and Contemporary Philosophy, edited by Andrew Chitty and Martin McIvor. New York: Palgrave Macmillan, 2009.

Cox, Judy. "How Marx and Engels fought for women's liberation." International Socialism, March 29, 2020. https://isj.org.uk/jcox-marx-engels-women-lib/.

Dalla Costa, Mariarosa and Selma James. The Power of Women and the Subversion of the Community. Bristol: Falling Wall Press, 1972.

De Beauvoir, Simone. Das andere Geschlecht: Sitte und Sexus der Frau. Hamburg: Rowohlt, 1983 [1949].

Delap, Lucy. "The 'Woman Question` and the Origins of Feminism." In The Cambridge History of Nineteenth Century Political Thought, edited by Gareth Stedman Jones and Gregory Claeys. Cambridge: Cambridge University Press, 20 II.

Dück, Julia and Katharina Hajek. mIntime Verhältnisses: Eine gesellschaftstheoretische Erweiterung der Debatte um soziale Reproduktion." In Feminismus und Marxismus, edited by Alexandra Scheele und Stefanie Wöhl, 220-233. Weinheim: Beltz Juventa, 2018.

Dunayevskaya, Raya. Rosa Luxemburg, Women's Liberation, and Marx's Philosophy of Revolution. Atlantic Highlands, NJ: Humanities Press, I982.

Engels, Friedrich. „Der Ursprung der Familie, des Privateigentums und des Staats."In Marx-Engels-Werke, vol. 2I. Berlin: Dietz, 1962.

Engels, Friedrich. "Die Entwicklung des Sozialismus von der Utopie zur Wissenschaft.«In Marx-Engels-Werke, vol. 19. Berlin: Dietz, 1987 [I880].

Engels, Friedrich. "Die Lage der arbeitenden Klasse in England.« In MarxEngels-Werke, vol. 2. Berlin: Dietz, 1972 [1845]

Engels, Friedrich. "Engels an Karl Kautsky, 16. Februar 1884." in MarxEngels-Werke, vol. 36. Berlin: Dietz, 1979.

Esping-Andersen, Gøsta. The Three Worlds of Welfare Capitalism. Princeton, NJ: Princeton University Press, 1990.

Evans, Richard. Sozialdemokratie und Frauenemanzipation im deutschen Kaisserreich. Bonn: Dietz Verlag, 1979.

Ferguson, Susan and David McNally. "Capital, Labour-Power, and Gender-Relations: Introduction to the Historical Materialism Edition of Marxism and the Oppression of Women."In Lise Vogel, Marxism and 
the Oppression of Women: Toward a Unitary Theory, xvii-xl. Chicago: Haymarket Books, 2013.

Fraser, Nancy. „Contradictions of Capital and Care." New Left Review Ioo (2016): 99-117.

Haarmann, Elisabeth. Schwestern zur Sonne zur Gleichheit: Die Anfänge der proletarischen Frauenbewegung. Hamburg: Ergebnisse-Verlag, 1985.

Hervé, Florence, ed. Geschichte der deutschen Frauenbewegung. Cologne: Pahl-Rugenstein, 1982.

Hoock-Demarle, Marie-Claire. "Frauen und Frauenemanzipation in Engels Briefen."MEGA-Studien Journal 2 (1996): 54-65.

Inman, Mary. In Woman's Defense. Los Angeles: The Committee to Organize the Advancement of Women, 1940.

Kautsky, Benedikt, ed. Friedrich Engels Briefwechsel mit Karl Kautsky. Vienna: Danubia-Verlag, 1955.

Kautsky, Karl. "Die Entstehung der Ehe und der Familie."Kosmos: Zeitschrift für einheitliche Weltanschaung auf Grund der Entwicklungslehre 12, no. 2 (1882): 190-207.

Kipka, Ronda and Vincent Streichhahn, „Kapital gegen Leben: Plädoyer für einen politik-ökonomischen Reproduktionsbegriff." Prokla 197, no. 4 (2019): 585-590.

Klinger, Cornelia. „Weder eine bürgerliche Ehe noch eine perverse Wahlverwandtschaft: Von Liberalismus und Frauenbewegung zu Neoliberalismus und Postfeminismus." In Liberalismus: Traditionsbestände und Gegenwartskontroversen, edited by Karsten Fischer and Sebastian Huhnholz. Baden-Baden: Nomos, 2019.

Krader, Lawrence. "Einleitung." In Die ethnologischen Exzerpthefte, edited by Lawrence Krader. Frankfurt am Main: Suhrkamp, 1976.

Krupskaja, Nadežda Konstantinovna. Zhenschina-rabotnica [The Woman Worker]. Munich, I90I.

Lion, Hilde. Zur Soziologie der Frauenbewegung: Die sozialistische und die katholische Frauenbewegung. Berlin: Herbig, 1926.

Marx Aveling, Eleanor and Edward Aveling. "The Woman Question: From a Socialist Point of View." Westminster Review I25 (I886): 207-222

Marx, Karl and Friedrich Engels. "Die deutsche Ideologie." In MarxEngels-Werke, vol. 3. Berlin: Dietz, 1969 [1846].

Marx, Karl. »Der Akkumulationsprozeß des Kapitals.«In Marx-Engels-Werke, vol. 23. Berlin: Dietz, 1962 [1867]. 
Marx, Karl. „Einleitung: Zur Kritik der Politischen Ökonomie.« In MarxEngels-Werke, vol. I3. Berlin: Dietz, I97I [1857].

Marx, Karl. »Lohn, Preis und Profit.«In Marx-Engels-Werke, vol. I6. Berlin: Dietz, 1962 [1865].

Millett, Kate. Sexus und Herrschaft. Die Tyrannei des Mannes in unserer Gesellschaft. Munich: Desch, I97I.

Morgan, Lewis H. Ancient Society. Tucson: University of Arizona Press, 1995 [1877].

Nagel, Editha. "Zur Geschichte der unmittelbaren Entstehung von Friedrich Engels's Schrift ‘Der Ursprung der Familie, des Privateigentums und des Staates und ihre Herausgabe in Deutschland (1884-1894)."Beiträge zur Marx-Engels-Forschung 3 (1978): 125-I4I.

Niggemann, Heinz. Emanzipation zwischen Sozialismus und Feminismus: Die sozialdemokratische Frauenbewegung im Kaiserreich. Wuppertal: Hammer, I98I.

Planert, Ute. Antifeminismus im Kaiserreich: Diskurs, soziale Formation und politische Mentalität. Göttingen: Vandenhoeck \& Ruprecht, 1998.

Richebächer, Sabine. Uns fehlt nur eine Kleinigkeit: Deutsche proletarische Frauenbewegung. Frankfurt am Main: Fischer Taschenbuch-Verlag, 1982.

Sachse, Mirjam. Von weiblichen Vollmenschen und Klassenkämpferinnen: Frauengeschichte und Frauenleitbilder in der proletarischen Frauenzeitschrift ,Die Gleichheit, (I89I-1923). Kassel: Universitätsbibliothek Kassel, 201 I.

Scharinger, Manfred. Geschlechterverhältnisse bei Marx und Engels: Eine kritische Auseinandersetzung. Vienna: Arbeitsgruppe Marxismus, 2007.

Scharinger, Manfred. Proletarische Frauenbewegung. Kritische Bilanz und politische Lehren. Vienna: Arbeitsgruppe Marxismus, 2009.

Seccombe, Wally. »The Housewife and Her Labour under Capitalism. New Left Review 83, no. I (1974): 3-24.

Stark, Sam. "Marx und die Frauenfrage." Zeitschrift für Ideengeschichte II, no. 3 (2017): 55-66.

Thönnessen, Werner. Frauenemanzipation: Politik und Literatur der Deutschen Sozialdemokratie zur Franenbewegung (1863-1933). Frankfurt am Main: Europäische Verlangsanstalt, 1969.

Twellmann, Margrit. Die deutsche Frauenbewegung: Ihre Anfänge und erste Entwicklung 1843-1889. Kronberg: Athenäum-Verlag, 1976.

Vogel, Lise. "Hausarbeitsdebatte." In Historisch-kritisches Wörterbuch, vol. I, edited by Frigga Haug, 540-554. Hamburg: Argument Verlag, 2003. 
Vogel, Lise. "Nachtrag: Hausarbeit neu gedacht." In Marxismus und Frauenunterdrückung: Auf dem Weg zu einer umfassenden Theorie. Münster: Unrast Verlag, 2019 [2000].

Vogel, Lise. Marxismus und Frauenunterdrückung: Auf dem Weg zu einer umfassenden Theorie. Münster: Unrast Verlag, 2019 [1983].

Welskopp, Thomas. "'Der Geist ächt männlichen Strebensı: Mikropolitik und Geschlechterbeziehungen im Vereinsmilieu der frühen deutschen Arbeiterbewegung.«Kurswechsel 3 (1997): 67-8I. 


\section{In the Shadow of Karl Marx \\ Perception and Reception of Friedrich Engels in the Digital Age \\ Riccardo Altieri}

\section{Reciprocity or Hierarchy?}

The following article is dedicated to Friedrich Engels's perception in academic literature. The aim is to determine why Engels was often overshadowed by Karl Marx, how he has been signored in the literature, and what influence this shift in perception has had on his own biography. The center of this study will be his presence on the Internet compared to that of Marx. Is there a reciprocity of both or a kind of hierarchy, where Marx is ranked (far) above Engels? But before talking about the two by name, a comparison of the concepts that subsume their theories under one term should take place first.

If one searches for the German term 'Engelsismus on the Internet, one will get different results on different platforms: while Google $(G)$ has 964 hits, there are 983 on Ecosia (E) and 71,80o on Bing (B) and Yahoo (Y). ${ }^{\mathrm{I}}$ The English translation ,Engelsism and 45,500 (G) hits. Comparing these terms with the corresponding terms 'Marxismus and 'Marxism, it can be quickly realized that Marx outperforms his contemporary Engels everywhere (Fig. I).

I Searches were conducted on Bing.com, Ecosia.org, Google.com, and Yahoo.com. Because of the often-identical algorithms behind B, E, and Y, the results are sometimes but not always the same. The used data are to be understood purely quantitatively; there is no qualitative differentiation regarding the plausibility of the search results. 


\begin{tabular}{|l|c|c|c|c|}
\hline $\begin{array}{r}\text { matches } \\
\text { for }\end{array}$ & Engelsismus & Marxismus & Engelsism & Marxism \\
\hline on & $7 \mathrm{I}, 800$ & 450,000 & 4,050 & $4,030,000$ \\
\hline Bing (B) & 983 & 450,000 & 4,050 & $4,030,000$ \\
\hline Ecosia (E) & 964 & I, 520,000 & 45,500 & $13,600,000$ \\
\hline Google (G) & 71,800 & 450,000 & 4,050 & $4,030,000$ \\
\hline Yahoo (Y) & & & & \\
\hline
\end{tabular}

Fig. 1: Search engine results for Marxism and Engelsism in German and English. Search date: April 4th, 2020.

A look at the results on Google, for example, offers the following: while the term Marxismus is approximately I, 575 times more common than Engelsismus, we find comparable tendencies for the English translation: there, the term `Marxism`scores nearly 300 times more hits than "Engelsism. "But do these numbers really reflect the performance ratio of the theoretical impact of those two authors? The Berlin Institute for Critical Theory would maybe contradict this assumption. In his Historical-Critical Dictionary of Marxism, Sven-Eric Liedmann wrote: "In a way, what has been commonly referred to as 'Marxism s since about 1890 is more a creation of Friedrich Engels than Karl Marx, so that Arnold Künzli could say that the expression ‘E[ngelsism] « was actually more appropriate. $\aleph^{2} \mathrm{~A}$ second tool provided by Google is one called Google Trends. Unfortunately, it is only possible to check the data from 2004 until the present, but in these years, another unambiguous fact emerges: Karl Marx (red) has an average impact of 27, while that of Friedrich Engels (blue) is only 3 (Fig. 2). The peak in 2018 refers to the 2ooth birthday of Karl Marx, which also had minor repercussions on the impact value of Engels.

2 Sven-Eric Liedmann, "Engelsismus, " in Historisch-Kritisches Wörterbuch des Marxismus, vol. 3: Ebene-Extremismus, ed. Wolfgang Fritz Haug (Hamburg: Argument-Verlag, 1997), 384. This refers to Arnold Künzli, Karl Marx. Eine Psychographie (Wien: Europa, 1966), I8. See also Helmut Hirsch, Friedrich Engels in Selbsterzeugnissen und Bilddokumenten (Hamburg: Rowohlt, 1968). 


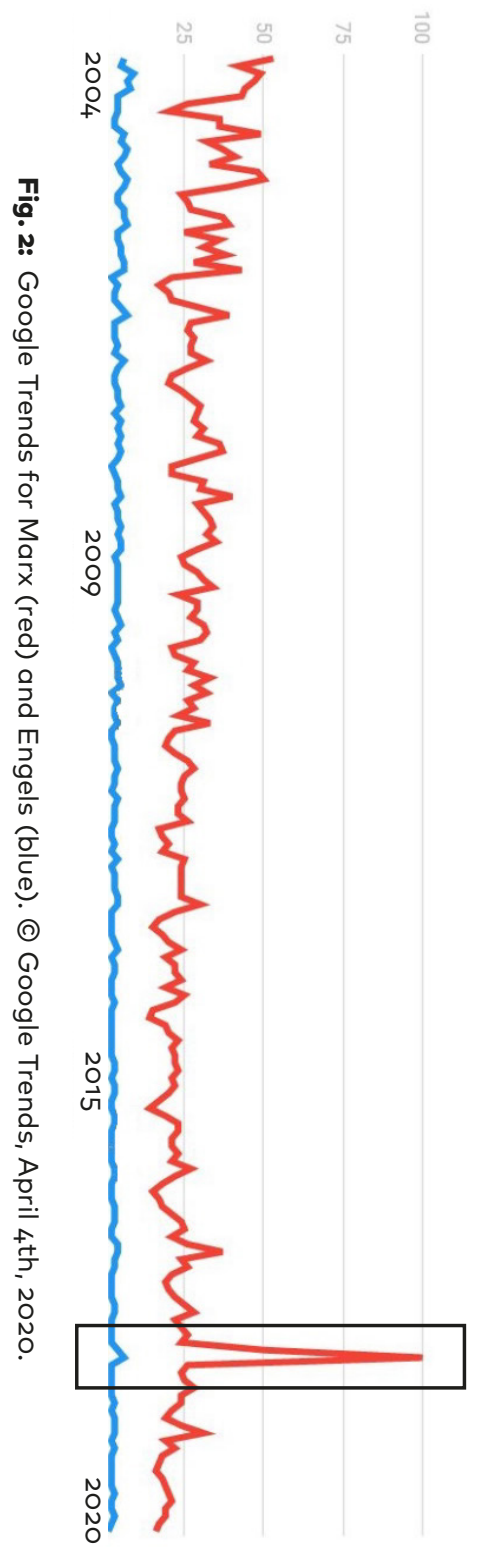


Although terms such as the former Marx-Engels Institute in Moscow, the Marx-Engels Works (Marx-Engels-Werke, MEW) or the Marx-Engels Complete Edition (Marx-Engels-Gesamtausgabe, MEGA') have the names of both philosophers in their titles, Karl Marx was always in the spotlight while Friedrich Engels stepped back. But this imbalance was not always so.

\section{Engels vs. Marx?}

At the beginning, Engels even stood before Marx. In the first years of the Second International, Engels was considered an "undisputed authority, « even an "oracle, « by labor leaders and theorists. ${ }^{3}$ How, when and where did this shift of perspective occur, then? "The orthodox Marxist-Leninist myth looks at Marx and Engels as intellectual twins who took on different tasks for practical reasons. «4 Accordingly, the short-term dominance of Engels can be determined during the early phase of his work, which is replaced by a reciprocity for the duration of orthodox Marxism-Leninism before Karl Marx was clearly granted preference in contemporary history and the digital age. Any kind of partisanship and comparison of the two, however, requires critical consideration, since it mostly takes place superficially. ${ }^{5}$

Again and again, Engels was accused of making fundamental mistakes in his reading of Marx, which would have led to a complete distortion of content that can still be found in the perception and reception through adaptation. ${ }^{6}$ Even Engels himself had problems with adequately reviewing Marx’s works, did not feel empowered, and

3 Liedmann, »Engelsismus, « 384.

4 Ibid.

5 Ingo Elbe, "Die Beharrlichkeit des ,Engelsismus`. Bemerkungen zum `Marx-Engels-Problem`," in Marx-Engels-Jahrbuch 2007, ed. Beatrix Bouvier et al. (München: Oldenbourg Akademie-Verlag, 2008), I05.

6 Ingo Elbe, Marx im Westen. Die neue Marxlektüre in der Bundesrepublik seit I965 (Berlin: Akademie-Verlag, 2008), 24; Jan Hoff, Marx global. Zur Entwicklung des internationalen Marx-Diskurses seit 1965 (Berlin: Akademie-Verlag, 2008), I99. 
was almost forced by his friend to grant him such a favor. ${ }^{7}$ Engels wrote: "Marx was a genius, the rest of us at most were talents. ${ }^{8}$ Jürgen Herres would contradict Engels here because, in his opinion, the latter was equal to his friend in terms of education, knowledge and language, and even superior in his linguistic skills. ${ }^{9}$ But later, he became part of the `Marx Party` and voluntarily submitted to his friend. Together they built a "unity of the different ones. ${ }^{10}$ In the year of Engels's 2ooth birthday, Hein Paler published a German book with the expressive title Friedrich Engels: The Creative Shadow, which is symbolic of his hidden-remaining character. ${ }^{\text {II }}$

It is common knowledge that Engels came from a well-known family of entrepreneurs, lived a bourgeois lifestyle throughout his life-recognizable by clothing style, living situation and habitus - and even owned millions in shares. Many only saw him as a socialist, comparable to a prophet who preaches water but then drinks wine himself, or in his case, champagne. He left not only $£ 2$ million on his death, but also 150 bottles of the expensive French beverage. ${ }^{12}$ But was it not precisely his financial security that made Marx's work even possible? Engels is not the only millionaire in history who was also a socialist or communist: Felix Weil, for example, was close to the Communist Party of Germany (KPD), and later the Communist Party of Germany (Opposition) (KPO) and also the Socialist Workers Party (SAP); $;^{13}$ Diether Dehm is a member of Die Linke (The Left) in

Previously contradicted by Hans-Holger Paul, Marx, Engels und die Imperialismustheorie der II. Internationale (Hamburg: VSA-Verlag, I978), 55.

7 Elbe, Marx, I05.

8 Quoted in Jürgen Herres, Marx und Engels. Porträt einer intellektuellen Freundschaft (Stuttgart: Reclam, 20I8), I8.

9 Ibid., I9.

IO Ibid., 7 .

II See Hein Paler, Friedrich Engels_-Der kreative Schatten (Norderstedt: Books on Demand, 2020).

I2 Ibid., I6-I7.

I3 See Jeanette Erazo Heufelder, Der argentinische Krösus. Kleine Wirtschaftsgeschichte der Frankfurter Schule (Berlin: Berenberg-Verlag, 20I7). 
the German Bundestag; ${ }^{14}$ and the Marxist-Leninist Party of Germany (MLPD) receives financial support from millionaires and their heirs for each election campaign ${ }^{15}$ - to name just three arbitrary examples. What they all have in common is that they themselves were never in the front row of the political movement, but always acted as patrons in the background or played a somewhat different subordinate role.

If we speak today of Marxism and less often of Engelsism, their works were by no means closed theories. Rather, it can be seen as a fragmentary œuvre. While Marx still published the first volume of Das Kapital during his lifetime, volumes 2 and 3 were edited and published by Engels after Marx's death. ${ }^{16}$ Taking everything into account, their work should be understood primarily as a contribution to early globalization and its counter-movement. ${ }^{17}$ It was precisely because he was so close to Marx that Engels was perfect for publishing and continuing his work. ${ }^{18}$ But this is also the main reason for his position within the reception of Marxist history. Michael Krätke stated that for the duration of orthodox Marxism-Leninism, the perceptions of Engels in the West and in the East went through different stages of development. In the Soviet Union and its allied states, the image of Engels had an increasingly negative connotation. "As a result, Engels was forgotten as a historian, as a political theorist and as a military specialist, and as a whole his intellectual achievement was irrelevant,

I4 Peter Jochen Winters, "Ist die PDS am Ende?, "in Zehn Jahre Deutsche Einheit. Eine Bilanz, ed. Wolfgang Thierse (Opladen: Leske+Budrich, 2000), I07.

I5 Kevin Hagen, "Sieger im Klassenkampf. Jahr für Jahr kassiert die linksextreme Splitterpartei MLPD riesige Summen von privaten Einzelspendern. Warum ist das so? Geschichten über das revolutionäre Erbe, « Spiegel online, December 29, 2015, https://www.spiegel.de/politik/deutschland/mlpd-die-grossspender-der-kom munisten-a-I06987i.html.

I6 Herres, Marx und Engels, II.

I7 Ibid., I2-I3.

I8 Michael R. Krätke, „Das Marx-Engels-Problem: Warum Engels das Marxsche ,Kapital nicht verfälscht hat, " in Marx-Engels-Jahrbuch 2006, ed. Beatrix Beauvier et al. (München: Oldenbourg Akademie-Verlag, 2007), I42. 
compared to the Marxian, his work was not congenially and rather negatively dismissed. (19 $^{\text {9 }}$

\section{Reception}

What did the reception of Engels look like in later decades? If one considers, for example, the Ist volume of the 2nd edition of Gustav Mayer's important Engels biography from 1934, Engels appears there over I,200 times (Fig. 3). Marx, however, is only mentioned 496 times. ${ }^{20}$ So Engels is mentioned about two and a half times as often as his friend. But how about in other works on both or written by them?

Of course, there is no publication that reaches the ideal value of I.o, since that would mean that Marx's and Engels's names were mentioned exactly the same number of times. But as these twenty examples clearly show, there are unambiguous trends: in the eight works that have Friedrich Engels as their central theme, the Engels-Marx factor always exceeds the value of I.O. Conversely, this value always fell below I.O in the six books that have Marx as their main subject. It really becomes interesting when looking at the values for the six examples that can be assigned to Marx and Engels equally. There, the value falls below I.O in each and every case. Although this tendency does not guarantee general statements, it allows forecasts that go in a clear direction: at least in the works that deal equally with Marx and Engels, Engels is apparently fundamentally surpassed by Marx-at least when it comes to the simple frequency of their names appearing. In the tabular example, Dethmann's work from 1920 (-I.19) achieved the ‘best value, whereas the 'worst result was achieved by Eubanks in I984 (-3.6I). Of all twenty examples chosen, Dethmann also achieved the stop result in the overall comparison. This work is the second oldest of those reviewed, whereas the 'worst result in total was in the

I9 Ibid., I43.

20 Gustav Mayer, Friedrich Engels. Eine Biographie. Erster Band: Friedrich Engels in seiner Frühzeit (The Hague: Springer Science+Business Media, 1934). 


\begin{tabular}{|c|c|c|c|c|c|c|c|c|c|}
\hline \multirow{2}{*}{$\begin{array}{l}20 \text { random works } \\
\text { by release date }\end{array}$} & \multicolumn{3}{|c|}{ Engels Biographies } & \multicolumn{3}{|c|}{ Marx Biographies } & \multicolumn{3}{|c|}{ Books on/by both } \\
\hline & Engels & Marx & factor & Engels & Marx & factor & Engels & Marx & factor \\
\hline $\begin{array}{l}\text { Mehring, Karl Marx } \\
\text { [I9I 8]. }\end{array}$ & & & & 806 & $\mathrm{I}, 820$ & -2.26 & & & \\
\hline $\begin{array}{l}\text { Dethmann, Rätege- } \\
\text { danke (I920). }\end{array}$ & & & & & & & I 26 & 150 & -I.I9 \\
\hline $\begin{array}{l}\text { Mayer, Friedrich } \\
\text { Engels [1920]. }\end{array}$ & I,206 & 496 & +2.43 & & & & & & \\
\hline $\begin{array}{l}\text { Marx/Engels, Die } \\
\text { deutsche Ideologie } \\
\text { [1932]. }\end{array}$ & & & & & & & 440 & 919 & -2.09 \\
\hline $\begin{array}{l}\text { Mescheryakov, Life } \\
\text { and Work (1933). }\end{array}$ & & & & 64 & 196 & -3.06 & & & \\
\hline $\begin{array}{l}\text { Berlin, Karl Marx } \\
\text { [I939]. }\end{array}$ & & & & II9 & 680 & $-5.7 \mathrm{I}$ & & & \\
\hline $\begin{array}{l}\text { McLellan, Karl } \\
\text { Marx [1973]. }\end{array}$ & & & & 718 & 3,305 & -4.60 & & & \\
\hline $\begin{array}{l}\text { Rosdolsky, Friedrich } \\
\text { Engels [1964]. }\end{array}$ & 552 & 208 & +2.65 & & & & & & \\
\hline $\begin{array}{l}\text { Marx/Engels, } A r \text { - } \\
\text { ticles (I969). }\end{array}$ & & & & & & & 243 & 320 & $-\mathrm{I} .32$ \\
\hline $\begin{array}{l}\text { Marx/Engels, Paris } \\
\text { Commune (I980). }\end{array}$ & & & & & & & I 37 & 369 & -2.69 \\
\hline $\begin{array}{l}\text { Eubanks, Marxism } \\
\text { [1984]. }\end{array}$ & & & & & & & 508 & $\mathrm{I}, 834$ & $-3.6 \mathrm{I}$ \\
\hline $\begin{array}{l}\text { Stepanova, Frederick } \\
\text { Engels [1985]. }\end{array}$ & $\mathrm{I}, 040$ & 807 & +1.29 & & & & & & \\
\hline $\begin{array}{l}\text { Schmitt, Introducti- } \\
\text { on [1987]. }\end{array}$ & & & & & & & 407 & $72 \mathrm{I}$ & $-\mathrm{I} .77$ \\
\hline $\begin{array}{l}\text { Carver, Friedrich } \\
\text { Engels (1990). }\end{array}$ & $\mathrm{I}, 243$ & 502 & +2.48 & & & & & & \\
\hline $\begin{array}{l}\text { Boden, Red Clause- } \\
\text { witz (200I). }\end{array}$ & $I, 325$ & 235 & +5.64 & & & & & & \\
\hline $\begin{array}{l}\text { Hunt, Marx's Gene- } \\
\operatorname{ral}(2009) \text {. }\end{array}$ & $\mathrm{I}, 623$ & 753 & +2.16 & & & & & & \\
\hline $\begin{array}{l}\text { Hollander, Friedrich } \\
\text { Engels (2OI I). }\end{array}$ & I,9 I I & 802 & +2.38 & & & & & & \\
\hline
\end{tabular}


Sperber, Karl Marx

(2013).

Heinrich, Karl Marx

(2018).

Brie, Sozialist-wer-

$\operatorname{den}(2020)$.
555

$2,448 \quad-4.4 \mathrm{I}$

$\begin{array}{lll}\text { I 4I } & \text { I,479 } & - \text { I0.49 }\end{array}$

Fig. 3: The Engels-Marx Ratio in (Biographical) Literature (1918-2020) ${ }^{21}$. (C) Riccardo Altieri, April 8th, 2020.

second most recent study, namely Heinrich's Marx biography from 2018 (-IO.49). The best overall result was achieved by the Master's thesis by Michael A. Boden, a Major in the US Army, from 200I (+5.64).

Especially in Germany, as a non-academic, Engels always had a hard time surviving in front of the inflated Marx. He had no high school or university degree and no doctorate. Or, as Krätke sums it up, »[i]n Germany, where academic cretinism has always blossomed, one has to add: the man wasn't even habilitated! ${ }^{22}$ Until today, Engels's own creativity is defined by his work in the service of Marx; for example, by the fact that he is considered to be the one whom Marx could always trust without reservation. ${ }^{23}$ In Western Marxism, there is also the exaggerated accusation that Engels did not understand his friend's work; maybe he defined Marxism, but he also garbled it up. He was accused of not having published the Marxian work in its orig-

2I All data for this survey come from files of the works of Marx and Engels that can be obtained in some way on the Internet. The formula for the factor follows mathematical law: big number divided by small number equals the factor. If the numerical value is exactly I.O, there is a reciprocity between Engels and Marx. If the factor is bigger than I.O, there is a gradient between Engels and Marx, and if it is smaller than I.O there is an incline between Engels and Marx. Of course, it is possible that the data are slightly distorted, considering that the name 'Marx also appears in terms such as `Marxism` or can refer to relatives with the same surname who are mentioned in the books. This also applies to Engelsism and the Engels family. So, this approach in fact underlines the argument.

22 Krätke, »Marx-Engels-Problem, « I43, fn. 5.

23 Ibid., I43-I44. 
inal wording. In doing so, he changed the text to such an extent that it seems possible to speak of a falsification. ${ }^{24}$ However, let us get back to the digital age.

\section{Engels and Marx in the Digital Age}

The results from various online search engines for the terms "Engelsismus/Engelsism" and "Marxismus/Marxism " have already been presented. But how about target words like "Friedrich Engels» and "Karl Marx«? In the following table (Fig. 4), the searchable platforms named before have been supplemented by specifically academic ones.

The number of scientific search engines is of course significantly higher than the chosen selection. However, in order not to exceed the confines of an essay, a maximum number of twenty was set again. In addition to the four search engines already used, sixteen explicitly academic tools were added. The decisive factor was not the level of the results obtained, but rather their general level of awareness. Although B, E and $\mathrm{Y}$ again use the same search algorithms, their result factor $(-5.72)$ is slightly better than that of $G(-6.06)$, which, however, was able to achieve significantly more hits. What is essential to note is how much higher the number of hits was in all four cases for the search term "Karl Marx" compared to "Friedrich Engels." And this one-sided trend unfortunately also runs through all the academic search engines.

The highest hit results were achieved for "Friedrich Engels« on infotopia $(\mathrm{I}, 300,000)$ and for "Karl Marx» on VirtualLRC (19,700,000). But both search engines are among the four sworst when it comes to optimizing the Engels-Marx factor. The top result was achieved by academic.microsoft.org (-I.55), which had the lowest hit rate, followed by Science.gov (-2.12). But however the numbers get interpreted, each

24 Ibid., I47. See also Michael Heinrich, "Engels's Edition of the Third Volume of Capital, and Marx’s Original Manuscript, « Science and Society 6o, no. 4 (I995). 


\begin{tabular}{|c|c|c|c|}
\hline $\begin{array}{l}\text { target words } \\
\text { searchable platforms }\end{array}$ & $\begin{array}{l}\text { Friedrich } \\
\text { Engels }\end{array}$ & $\begin{array}{l}\text { Karl } \\
\text { Marx }\end{array}$ & factor \\
\hline Bing.com (B) & I,030,000 & $5,890,000$ & $-5 \cdot 72$ \\
\hline Ecosia.org (E) & $\mathrm{I}, 030,000$ & $5,890,000$ & $-5 \cdot 72$ \\
\hline Google.com (G) & $4,260,000$ & $25,800,000$ & -6.06 \\
\hline Yahoo.com (Y) & I,030,000 & $5,890,000$ & $-5 \cdot 72$ \\
\hline $\begin{array}{l}\text { Academia.edu } \\
\text { Paper titles } \\
\text { Papers (full articles) }\end{array}$ & $\begin{array}{c}I 43 \\
25,678\end{array}$ & $\begin{array}{l}\text { I } 346 \\
\text { I } 46,000\end{array}$ & $\begin{array}{l}-9.4 I \\
-5.68\end{array}$ \\
\hline academic.microsoft.org & 293 & 455 & $-I .55$ \\
\hline Baidu.com & I 5,800 & 75,100 & $-4 \cdot 75$ \\
\hline base-search.net & $\mathrm{I}, \mathrm{I} 42$ & I0,806 & -9.46 \\
\hline core.ac.uk & I 2,669 & $7 \mathrm{I}, 445$ & -5.64 \\
\hline Google Scholar & I 26,000 & $\mathrm{I}, 040,000$ & -8.25 \\
\hline Infotopia & $\mathrm{I}, 300,000$ & I 5,400,000 & -I I.85 \\
\hline jstor.org & 10,636 & 60,666 & -5.70 \\
\hline Libgen.is & $42 I$ & 999 & -2.37 \\
\hline refseek.com & 329,000 & $4,130,000$ & -I 2.55 \\
\hline ScienceDirect.com & 529 & 7,857 & $-I 4.85$ \\
\hline Science.gov & I98 & 419 & -2.12 \\
\hline semanticscholar.org & I 3,400 & $7 \mathrm{I}, 400$ & $-5 \cdot 33$ \\
\hline VirtualLRC.com & I,060,000 & I9,700,000 & -I 8.58 \\
\hline worldcat.org & 22,295 & I 20,00 I & $-5 \cdot 38$ \\
\hline worldwidescience.org & 702 & $\mathrm{I}, 482$ & $-2 . \mathrm{II}$ \\
\hline
\end{tabular}

Fig. 4: Search results for Marx and Engels on academic platforms.

(C) Riccardo Altieri, April gth, 2020 
result reflects that Karl Marx can be found in the digital world many times more often than his friend and contemporary Friedrich Engels. This process, which has now lasted well over Ioo years and has only recently emerged in the digital age, is unstoppable in its development and also irreversible.

Freed from the dogmata of the Cold War era, this observation is just an observation and nothing else. No course corrections or sentimentalities are required here. For historical science, data can be derived from this on the question of how an apparently historically equivalent personality can be marginalized over decades by setting an ideological focus. Internal Marxist debates showed long ago that, in the case of Engels vs. Marx, there is no >right dition to this special situation, methodical-analytical approaches are also appropriate for comparable stwin pairs in history: for example, Romulus and Remus, Goethe and Schiller, or Liebknecht and Luxemburg. Almost always, one benefited from the other and outshone his partner through his own growth-intentionally or unintentionally.

\section{Final remarks}

To take a step back, Marx position and ranking was, to a certain extent, a conscious decision by Friedrich Engels himself, too. To name just one example, Marx's death in the year of I883 should be mentioned here. When he died, friends like Johann Philipp Becker (I809-I886)

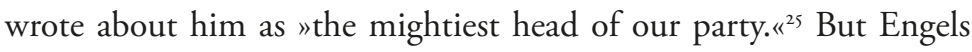
also put him on an indisputable podium. Instead of talking about the loss of his friend, in his funeral speech, he regretted the loss of his fellow combatant and spoke of him as the "greatest living thinker«: "Like Darwin with the law of the development of organic na-

25 Quoted in Hans Peter Bleuel, Friedrich Engels. Bürger und Revolutionär. Die zeitgerechte Biographie eines großen Deutschen (Bern/München: Scherz-Verlag, 198I), 359 . 
ture, Marx discovered the law of development of human history. ${ }^{126}$ German Social Democrats, specifically August Bebel, asked Engels to give up his British exile and come back to Germany. But he refused. ${ }^{27}$ Perhaps that would have been the moment when Engels could have stepped out of the shadows to follow in the footsteps of his revered friend. Instead, he devoted himself to the publication of the estate, thereby increasing Marx's later reputation.

In the first foreword to the 1883 German edition of the Communist Manifesto, which he signed alone, Engels wrote: »Unfortunately, I have to sign the foreword to the current edition alone. Marx, the man to whom the entire working class of Europe and America owes more than anyone else-Marx lies in the Highgate cemetery, and the first grass is already growing over his grave." Then he put forward the basic ideas of the manifesto, which he had written together with Marx, only to add: "This basic idea belongs only and exclusively to Marx. I have said this many times, but it is necessary now to do it also before the Manifesto itself. ${ }^{28}$ In the foreword to the English edition of I888, he reduced his performance in the manifesto even further: "Although the >Manifesto was the work we both did, I feel obliged to state that the basic idea at its core belongs to Marx. $\ll^{29}$

A question might now arise as to why Engelsism never really developed alongside Marxism, especially in a positive connotation. $\mathrm{Ru}$ dolf Walther knows the right answer when he writes about Engels that " $[\mathrm{t}]$ he one who lived, thought, and wrote so freely was and is too good for a church, a sect, or a party and all their Isms. ॥º $^{30}$ But apart

26 Quoted in ibid., 360.

27 Ibid., 362-363.

28 Friedrich Engels, "Vorwort zur deutschen AusgabeI883, " in Manifest der Kommunistischen Partei, ed. Karl Marx and Friedrich Engel (Berlin: Karl-Dietz-Verlag, 1959), xvii-xviii.

29 Friedrich Engels, "Vorrede zur englischen Ausgabe von 1888, "in Manifest der Kommunistischen Partei, ed. Karl Marx and Friedrich Engel (Berlin: Karl-DietzVerlag, 1959), xxiii.

30 Rudolf Walther, Aufgreifen, begreifen, angreifen. Historische Essays, Porträts, politische Kommentare, Glossen, Verrisse (Münster: Oktober Verlag, 20II), 232. 
from that, the question about why Marx is clearly overrepresented on the Internet, as he previously was in the literature, remains justified, and we must also ask how Engels can be better served in the future. If there were no answers to this, science would have no choice but to agree with Engels in his humble judgment when he wrote to Eduard Bernstein (1850-1932) while Marx was still alive, which he expressed as follows: "I don't understand how to be jealous of a genius; it is such a thing of its own kind that we, who do not have it, know in advance that it is unreachable for us. «I The 2ooth birthday of Engels may at least increase interest in the man, who was an important intellectual not only following Marx, but next to him.

A judgment by Josef Stalin (I878-1953) that he expressed on Engels should convince the last doubters, however, that the philosopher deserves to be put in the spotlight as an independent personality-and, of course, in contrast to the dictator's purge fantasies: „Even Engels was not right about everything. It wouldn't be a bad thing if we could implicate Engels somewhere in Nikolai Bukharin's (I888-1938) writing. (12 $^{32}$ It is well-known what Stalin thought of Bukharin, although his murder was a completely different way of removing someone from the collective memory.

\section{Works Cited}

Berlin, Isaiah. Karl Marx. His Life and Environment. 4th ed. Oxford: Oxford University Press, 2002 [1939].

Bleuel, Hans Peter. Friedrich Engels. Bürger und Revolutionär. Die zeitgerechte Biographie eines großen Deutschen. Bern/München: Scherz-Verlag, I98I.

Boden, Michael A. "'The First Red Clausewitz: Friedrich Engels and Early Socialist Military Theory, I848-I870.« MA diss., U.S. Army Command and General Staff College, 200I.

3I Quoted in Herres, Marx und Engels, I8.

32 Quoted in Alan Bullock, Hitler and Stalin: Parallel Lives (Toronto: McClelland \& Stewart, 1993), 402. 
Brie, Michael. Sozialist-werden. Friedrich Engels in Manchester und Barmen, I842-I845. Berlin: Rosa-Luxemburg-Stiftung, 2019.

Bullock, Alan. Hitler and Stalin: Parallel Lives. Toronto: McClelland \& Stewart, I993.

Carver, Terrell. Friedrich Engels. His Life and Thought. New York: Palgrave Macmillan, I990.

Dethmann, Adolf. „Der Rätegedanke als Staatstheorie und seine Keime in den Schriften von Karl Marx und Friedrich Engels." PhD thesis, Kiel, I920.

Elbe, Ingo. „Die Beharrlichkeit des `Engelsismus`. Bemerkungen zum ,Marx-Engels-Problem «. In Marx-Engels-Jahrbuch 2007, edited by Beatrix Bouvier et al., 92-I05. München: Oldenbourg Akademie-Verlag, 2008.

-. Marx im Westen. Die neue Marx-Lektüre in der Bundesrepublik seit I965. Berlin: Akademie-Verlag, 2008.

Engels, Friedrich. "Vorrede zur englischen Ausgabe von I888."In Manifest der Kommunistischen Partei, edited by Karl Marx and Friedrich Engels, xix-xxv. Berlin: Karl-Dietz-Verlag, 1959.

-. "Vorwort zur deutschen Ausgabe von I883."In Manifest der Kommunistischen Partei, edited by Karl Marx and Friedrich Engels, xvii-xviii. Berlin: Karl-Dietz-Verlag, I959.

Erazo Heufelder, Jeanette. Der argentinische Krösus. Kleine Wirtschaftsgeschichte der Frankfurter Schule. Berlin: Berenberg-Verlag, 2017.

Eubanks, Cecil L. Karl Marx and Friedrich Engels. An Analytical Bibliography. 2nd ed. London/New York: Routledge, 2015 [1984].

Hagen, Kevin. "Sieger im Klassenkampf. Jahr für Jahr kassiert die linksextreme Splitterpartei MLPD riesige Summen von privaten Einzelspendern. Warum ist das so? Geschichten über das revolutionäre Erbe.« Spiegel online, December 29, 2015. https://www.spiegel.de/politik/deutschland/ mlpd-die-grossspender-der-kommunisten-a-I06987I.html.

Heinrich, Michael. "Engel's Edition of the Third Volume of Capital, and Marx’s Original Manuscript. «Science and Society 60, no. 4 (I995): 452-466.

- Karl Marx and the Birth of Modern Society: The Life of Marx and the Development of His Work. Vol. I: I8I8-I84I. New York: Monthly Review Press, 2018.

Herres, Jürgen. Marx und Engels. Porträt einer intellektuellen Freundschaft. Stuttgart: Reclam, 2018.

Hirsch, Helmut. Friedrich Engels in Selbstzeugnissen und Bilddokumenten. IIth ed. Hamburg: Rowohlt, I968. 
Hoff, Jan. Marx global. Zur Entwicklung des internationalen Marx-Diskurses seit 1965. Berlin: Akademie-Verlag, 2009.

Hollander, Samuel. Friedrich Engels and Marxian Political Economy. Cambridge: Cambridge University Press, 2011.

Hunt, Tristram. Marx's General: The Revolutionary Life of Friedrich Engels. New York: Metropolitan Books, 2009.

Krätke, Michael R. „Das Marx-Engels-Problem: Warum Engels das Marxsche 'Kapital nicht verfälscht hat." In Marx-Engels-Jahrbuch 2006, edited by Beatrix Bouvier et al., I42-I70. München: Oldenbourg Akademie-Verlag, 2007.

Künzli, Arnold. Karl Marx. Eine Psychographie. Wien: Europa, 1966.

Liedmann, Sven-Eric. „Engelsismus. "In Historisch-Kritisches Wörterbuch des Marxismus, vol. 3: Ebene-Extremismus, edited by Wolfgang Fritz Haug, 384-392. Hamburg: Argument-Verlag, 1997.

Marx, Karl and Frederick Engels. On the Paris Commune. 3rd ed. Moscow: Progress Publishers, 1980.

Marx, Karl and Friedrich Engels. Articles in the New American Cyclopaedia. Edited by Hal Draper. Berkley, CA: Independent Socialist Press, I969.

- Die deutsche Ideologie. Edited by Harald Bluhm. Berlin: Akademie-Verlag, 20IO [1932].

Mayer, Gustav. Friedrich Engels. Eine Biographie. Erster Band: Friedrich Engels in seiner Frühzeit. 2nd ed. The Hague: Springer Science+Business Media, 1934 [1920].

McLellan, David. Karl Marx: A Biography. 2nd ed. London: Macmillan, I995.

Mehring, Franz: Karl Marx. The Story of His Life. Ann Arbor, MI: University of Michigan Press, 1962 [1918].

Mescheryakov, Nicolai Leonidovich: The Life and Work ofKarl Marx. Moscow/ Leningrad: Co-Operative Publishing Society of Foreign Workers in the USSR, 1933 .

Paler, Hein. Friedrich Engels_Der kreative Schatten. Norderstedt: Books on Demand, 2020.

Paul, Hans-Holger. Marx, Engels und die Imperialismustheorie der II. Internationale. Hamburg: VSA-Verlag, 1978.

Rosdolsky, Roman. Friedrich Engels y el Problema de los Pueblos "sin Historia". La Questión de las Nacionalidades en la Revolution de I848-1849 a la Luz de la "Neue Rheinische Zeitung". México City: Ediciones Pasado y Presente, I980 [German 1964]. 
Schmitt, Richard. Introduction to Marx and Engels: A Critical Reconstruction. and ed. Boulder, CO: Westview Press, I997 [1987].

Sperber, Jonathan: Karl Marx: A Nineteenth-Century Life. New York/London: Liveright Publishing Corp., 2013.

Stepanova, Yevgenia. Frederick Engels: A Short Biography. Moscow: Progress Publishers, I988 [1985].

Walther, Rudolf. Aufgreifen, begreifen, angreifen. Historische Essays, Porträts, politische Kommentare, Glossen, Verrisse. Münster: Oktober Verlag, $201 \mathrm{I}$.

Winters, Peter Jochen. "Ist die PDS am Ende?» In Zehn Jahre Deutsche Einheit. Eine Bilanz, edited by Wolfgang Thierse et al., 99-II2. Opladen: Leske + Budrich, 2000 . 



\section{Post-Truth Coronavirus Outbreak \\ Engels's Perspective}

Nuruddin Al Akbar

"But the necessity of authority, and of imperious authority at that, will nowhere be found more evident than on board a ship on the high seas. There, in time of danger, the lives of all depend on the instantaneous and absolute obedience of all to the will of one." -Friedrich Engels ${ }^{1}$

"[T]here is no fixed and constant authority, but a continual exchange of mutual, temporary, and, above all, voluntary authority and subordination." -Mikhail Bakunin²

"Today humanity faces an acute crisis not only due to the coronavirus, but also due to the lack of trust between humans. To defeat an epidemic, people need to trust scientific experts, citizens need to trust public authorities, and countries need to trust each other. [...] In this moment of crisis, the crucial struggle takes place within humanity itself. If this epidemic results in greater disunity and mistrust among humans, it will be the virus's greatest victory." -Yuval Noah Harari ${ }^{3}$

I Friedrich Engels, "On Authority, " in The Marx-Engels Reader, ed. Robert C. Tucker (New York: W. W. Norton, 1978), 732.

2 Mikhail Bakunin, "What is Authority?" The Marxists Internet Archive, accessed April I, 2020, https:/www.marxists.org/reference/archive/bakunin/works/various/ authrty.htm.

3 Yuval Noah Harari, »In the Battle Against Coronavirus, Humanity Lacks Leadership, "Time, March I5, 2020, https://time.com/5803225/yuval-noah-harari- 


\section{Introduction: Reading Engels in the Time of the Coronavirus Outbreak}

This study seeks to elaborate on the thoughts of Friedrich Engels (1820-1895) about authority. ${ }^{4}$ This study is important because, traditionally, the name Engels tends to be considered »small« compared to his colleague Karl Marx (I818-1883).5 Many of Marx's ideas were born together with Engels, such as the Communist Manifesto (I848), a monumental work that raised Marx to the status of one of the world's leading thinkers that endures to this day. ${ }^{6}$ Another of Marx's impressive works that is known to the world today, Das Kapital, also could not have been born without the help of Engels. ${ }^{7}$ Marx is known as a person who read more than he wrote. ${ }^{8}$ The reason is predictably that Marx wanted his writing to be a work built on strong theoretical and data foundations. ${ }^{9}$ However, Engels had another consideration,

coronavirus-humanity-leadership/.

4 In particular, the study considers his short writings entitled On Authority« and "Versus the Anarchists. "Although short, a lot of inspiration can be drawn from the writings of Engels, primarily to help us understand contemporary phenomena such as the coronavirus outbreak.

5 Terrell Carver, Engels: A Very Short Introduction (Oxford: Oxford University Press, 2003), vii.

6 Tristram Hunt, Marx's General: The Revolutionary Life of Friedrich Engels (New York: Holt Paperbacks, 2009), I-2.

7 Even after the publication of Das Kapital, Engels was instrumental in introducing this book to a broad audience. For example, Engels wrote nine reviews about Das Kapital that had a positive tone. Engels also became a supervisor in the translation of the book into English so that Marx's work could gain a wider audience. See Shlomo Avineri, Karl Marx: Philosophy and Revolution (New Haven: Yale University Press, 2019), I44; Michael Charles Howard and John Edward King, $A$ History of Marxian Economics, vol. I: I883-1929 (Princeton, NJ: Princeton University Press, 1989), 8.

8 Michael Evans, Karl Marx (London: Routledge, 2004), 47.

9 For example, Marx did not want to rush to complete the second volume because he wanted to get accurate data about the latest developments that had occurred in the UK related to the potential crisis of capitalism. See Bertell Ollman, Alienation: Marx's Conception of Man in Capitalist Society (London: Cambridge University Press, 197I), 62. 
wherein the publication of Das Kapital — of which Marx planned to publish six volumes - would not be finished if Marx read too much. Because Marx used more and more of his time to read, to explore particular topics, extra work was needed, and in the end, the writing of Das Kapital continued to be delayed. ${ }^{\text {o }}$ Finally, thanks to Engels's insistence, Marx was able to complete the first volume of the original six-volume plan that Marx envisioned. ${ }^{\text {II }}$ Engels was also instrumental in editing Marx's second and third volumes of Das Kapital, which were left unfinished until the end of his life, and later, Engels chose to publish them. ${ }^{12}$ In other words, Engels was a »big « intellectual, as was his colleague Marx. ${ }^{13}$

However, it is unfortunate even long after his death, Engels's name is still positioned as a "complement" to the big-name Marx (even in the academic world, his ideas are known as Marxism and not Engelsism ${ }^{14}$ )

Io Even after the publication of the first volume, Marx felt that his work was still not perfect. He stressed that he would revise his work if he found new findings from the results of his research process and critical readings on various issues. See Paul Prew, Tomás Rotta, Tony Smith and Matt Vidal, "The Enduring Relevance of Karl Marx, " in The Oxford Handbook of Karl Marx, ed. Tomás Rotta, Tony Smith, Matt Vidal and Paul Prew (New York: Oxford University Press, 2019), I3.

II William Otto Henderson, The Life of Friedrich Engels Volume II (London: Routledge, 1976), 399.

I2 Lars Magnusson and Bo Stråt, A Brief History of Political Economy: Tales of Marx, Keynes and Hayek (Cheltenham: Edward Elgar, 2016), Io.

I3 William Otto Henderson, The Life of Friedrich Engels Volume I (London: Frank Cass, 1976), xi; Peter Singer, Marx: A Very Short Introduction (Oxford: Oxford University Press, 2000), 59.

I4 Regarding with the term Englelsism, it can be said that, there is a unique tendency among some academics who seek to "purify« Marxism from Engels's influence. The attempt to "purify« Marxism was driven, for example, by their suspicion of Engels, who was the editor of some of Marx's works such as the second and third volumes of Das Kapital. They feared that Engels's subjective interpretation influenced the originality of Marx's work. In other words, there was the potential for Marx's ideas to be interfered with by Engels's thought as a thinker who had different ideas to Marx. So for these academics, further studies must be conducted to clarify the influence of Engels on Marx's work. This trend is rather excessive, because Engels can be said to be a figure who 
so serious studies on him by academics are lacking. ${ }^{\text {is }}$ But now it is undeniable that a new trend has also emerged. Many academics are now interested in studying the figure and thought of Engels. ${ }^{16}$ This new trend in studying Engels seriously is something to be celebrated because, with the increasing number of academics involved, the in-

contributed to shaping Marx's thinking, so it would be naive if they wanted to erase the role of Engels in the formulation of Marxism. However, if the direction of this trend is to uncover the vital role of Engels in formulating Marxism, then this tendency can be accepted. Marx and Engels must be appreciated as intellectuals who both contributed to the creation of an original idea called scientific socialism. See Carver, Engels, I2-I3.

I5 Terrell Carver is one of the academics who are aware of the lack of fascination in the academic world with positioning Engels as a brilliant thinker. Even the number of those who study him as a historical figure is relatively small. Carver has tried to fill this academic vacuum by writing an introduction to placing Engels as an independent thinker who deserves to be taken into account in the academic world. See Carver, Engels, vii; Terrell Carver, Friedrich Engels: His Life and Thought (New York: St. Martin's Press, 1990), xvi.

I6 For example, two biographies of Engels written by two different authors appeared at not too distant times. The first book by John Green is titled Engels: A Revolutionary Life and the second book written by Tristam Hunt is titled Marx's General: The Revolutionary Life of Friedrich Engels. Although they focus more on the historical side of Engels and do not explicitly elaborate on his thinking, both books got a warm appreciation from both contemporary socialists and non-Marxist academics. Interestingly, this appreciation was at the same time their affirmation that Engels was a thinker who could not merely be "reduced " to a subordination of Marx. Ian Angus, who wrote a review for the Socialist Review, appreciates the books as works that fill the void in the study of Engels. Angus even states that there have only been two biographical studies of Engels in the Ioo years since the death of the great thinker, namely the works of Gustav Meyer (1936) and William Henderson (1976). The two works are now out of print, so it is difficult for public audiences to access them. Angus also encouraged a more serious study of Engels with an emphasis on the ideas he generated, rather than merely studying the life of Engels. Likewise, Martin Jacques - a non-Marxist academic — appreciated Hunt's work as one that gave readers a new insight into the life of Engels. Despite the scarcity of studies of Engels, Hunt was able to show that he is a great thinker-equivalent to Marx. See Ian Angus, "Two Accounts of Engels's Revolutionary life, "Socialist Voice, August 24, 2009: 28; Martin Jacques, "Marx's Keeper, "The Guardian, May 2, 2009, https:/www.theguardian.com/books/2009/may/o2/frock-coated-engelshunt. 
formation discovered on the history of the life and intellectuality of Engels that was previously unknown to the public will be priceless treasure. ${ }^{17}$ The exploration of the life history of Engels is undoubtedly not only crucial for the academic world but also for the general public. This view is no exaggeration because, like Marx, Engels was a man who walked in a critical tradition in which he was committed to developing the project of the emancipation of the people from the various forms of oppression that enveloped them..$^{18}$ This study is expected to be a complement to previous works on Engels. In other words, it is hoped that this work can become part of a new trend of Engels studies. This work highlights Engels's ideas about authority, as he turned the debate about authority in an axiological direction. For Engels, authority can be emancipatory but also can be oppressive. Engels stated that if one negates the distinction between the two models of authority, then what happens is chaos because that authority is necessary, especially in emergencies. ${ }^{19}$ This study argues that Engels's thought is relevant for understanding contemporary phenomena, specifically those related to COVIDI9. ${ }^{20}$ This paper argues that the coronavirus outbreak is unique be-

I7 J.S. McClelland, for example, underlines several of Engels's intellectual works in the context of the development of Marxism that might not have been previously realized by many parties. For example, according to McClelland, Engels contributed to giving Marx knowledge about Feuerbach's criticism of Hegel. So it is not surprising that Marx's critique of Feuerbach is printed along with Engels's work on Feuerbach (as an appendix). McClelland himself concluded that Engels's position was not subordinate but equivalent to Marx. See J.S. McClelland, A History of Western Political Thought (London: Routledge, 1996), 574 .

I8 José Manuel Sánchez Bermúdez, The Neoliberal Pattern of Domination: Capital's Reign in Decline (Leiden: Brill, 20I2), 87.

I9 Engels, "On Authority, " 732; Friedrich Engels, "Versus the Anarchists, " in The Marx-Engels Reader, ed. Robert C. Tucker (New York: W. W. Norton, 1978), 729.

20 The medical world gave this virus the name COVID-I9 as an identity marker to distinguish it from other types of coronavirus. When the term coronavirus is used in this study, this refers to COVID-I9, not to another type of coronavirus. See Jianxing Yu, "Confronting and Governing the Public Health Emergency," Journal of Chinese Governance 5, no. 2 (2020): 137-139. 
cause it grew in the post-truth era, ${ }^{21}$ so it can be said that it is the first post-truth outbreak of the 2ist century. ${ }^{22}$

Furthermore, this study is considered even more important because although other works on Engels have begun to emerge, attempts to contextualize the ideas of Engels with contemporary events can be said to be very rare. ${ }^{23}$ Recall that in 2008 when the global economic

2I The term post-truth has become popular since it was named as the 2016 Word of the Year by Oxford Dictionaries. Oxford Dictionaries defines post-truth as a condition in which objective factors influence public opinion less than emotions and personal beliefs. Oxford Dictionaries definition emphasizes the binary opposition between facts and opinions where subjective opinions have more of an effect on people in the post-truth era. This study argues that post-truth is built on facts. But it also agrees with Keyes notion that there is a blur between fact and fiction. That means that post-truth description is not merely an opinion, but the reality is wrapped up in a story that tends to be fiction (or difficult to verify). Post-truth is not only a matter of the decaying boundary between facts and opinions but also its effect on society. It can be said that post-truth is almost sure to cause unrest, fear, and panic for the public so they take actions that tend to be irrational. See Kai Horsthemke, "»\#FactsMustFall??-Education in a Post-Truth, Post-Truthful World, "Ethics and Education I2, no. 3 (2017): 273-288; Scott Wilson, "Pre-Truth, Post-Truth and the Present: Jacques Lacan and the Real Horror of Contemporary Knowledge, " in Post-Truth and the Mediation of Reality: New Conjunctures, ed. Rosemary Overell and Brett Nicholls (Cham, Switzerland: Springer, 2020), 154; Lisa Portmess, "Post-Truth: Marcuse and New Form of Social Control, in America's Post-Truth Phenomenon: When Feelings and Opinions Trump Facts and Evidence, ed. C. G. Prado (Santa Barbara: Preager, 2018), 65.

22 Although not similar, there is a previous study conducted by Hakkı Taş in which he tried to understand one particular event as a post-truth event. In his research, Taş examines the failed coup that occurred on I5 July 2016 in Turkey as an example of a post-truth coup. Taş explicitly used the term "Turkey post-truth coup» because the nature of the coup was filled with a variety of bombastic narratives (about the Gulenist conspiracy), very little of which was supported by robust data. The impact of the coup itself became a new marker for politics in Turkey, termed by Taş as "new Turkey, " where, according to the author, the failed coup became an excuse for Erdogan to strengthen his grip on the country by making himself a hero who had succeeded in defeating foreign conspiracies (such as the US and Germany were accused of being involved in) that had aimed at overthrowing him. See Hakkı Taş, "The Is July Abortive Coup and Post-Truth Politics in Turkey," Southeast European and Black Sea Studies I8, no. I (2018): I4-I5.

23 An exception, for example, is the work of Michael Löwy, who tried to develop the tradition of eco-socialism. Interestingly, Löwy underlines Engels's work, 
crisis occurred, there was a strong attraction from academics-and also from the public - to Marx's ideas. ${ }^{24}$ The financial crisis that began in the US, where there was a problem of credit, eventually spread widely and impacted various countries in the world. ${ }^{25}$ Some academics, for example, issued arguments that the global economic crisis was following Marx's thesis on the plight of capitalism ${ }^{26}$ where capitalism tries to defend itself from a crisis by introducing several strategies, one of which is through the credit system, to ensure the small bourgeoisie does not collapse. But the effort of capitalism to maintain its existence ultimately has limitations. These limitations were reflected in the occurrence of bad credit in the US, and finally, led to the crisis of global capitalism. ${ }^{27}$ This study cannot elaborate the argument further for reasons of space, but this does underline that Marx's ideas have been discussed again. Even at the grassroots level, the thoughts of

which sought to draw a link between the destruction of nature (forests in Cuba) and the Spanish colonial capitalist production system that operates in the region. Although, according to Löwy, Engels did not elaborate much on the linkage between capitalism and environmental damage more systematically, Engels's idea could become a foundation for developing a Marxist analysis of current global ecological damage. See Michael Löwy, "Marx, Engels, and Ecology, Capitalism Nature Socialism 28, no. 2 (2017): I6.

24 Slavoj Zizek, a well-known scholar who studies Lacanian philosophy, is one of the academics who affirmed a new trend of intellectual and public excitement about the ideas of political economy developed by Marx. Beyond academics like Zizek, popular media also became involved in the trend; Time, for example, released a special edition on February 2, 2009 with the provocative title "Global financial crisis: What would Marx think? « See Christian Fuchs, „Dallas Smythe Today-The Audience Commodity, the Digital Labour Debate, Marxist Political Economy and Critical Theory. Prolegomena to a Digital Labour Theory of Value, " in Marx and the Political Economy of the Media, ed. Christian Fuchs and Vincent Mosco (Leiden: Brill, 20I6), 523.

25 Paul st Hart and Karen Tindall, "From 'Market Correction` to 'Global Catastrophes: Framing the Economic Downturn, " in Framing the Global Economic Downturn: Crisis Rhetoric and the Politics of Recessions, ed. Paul it Hart and Karen Tindall (Canberra: ANU E Press, 2009), 3.

26 Peter Hudis, Marx's Concept of the Alternative to Capitalism (Leiden: Brill, 20I2), I-2.

27 Christian Fuchs, Digital Labour and Karl Marx (New York: Routledge, 20I4), I3. 
Marx received much appreciation and became the basis of inspiration for the emergence of the 20II Occupy Wall Street movement in the US. ${ }^{28}$ This took place in New York with people chanting the slogan, "we are the $99 \%$." This development means that Marx's ideas have been discussed again both in public and academic circles because his ideas are considered relevant in reading contemporary phenomena.

A strong interest in Marx can be found again with the outbreak of the coronavirus. For example, academics like David Harvey have tried to apply Marx's ideas to understand the origin of the coronavirus outbreak. ${ }^{29}$ Harvey's analysis is in line with the big ideas developed by eco-Marxist exponents who are trying to develop a Marxist analysis to see the link between capitalism and natural exploitation, which leads to environmental damage. ${ }^{30}$ The difference is that Harvey specifically developed an argument about the connection between capitalism, the exploitation of nature, and the emergence of the coronavirus. ${ }^{3 \mathrm{I}}$ Harvey argued that nature became a kind of "iron cage « that traps many dangerous viruses. However, the destruction of nature

28 Singer, Marx, I05.

29 Harvey, a contemporary Marxist geographer, analyzed the coronavirus outbreak as an unintended consequence of a capitalist system that sought to turn nature into mere industrial raw material. Harvey's idea was in line with non-Marxist academics such as David Quammen, who believes that the disruption of ecosystems by human activity causes viruses. According to Quammen, the viruses are then targeting humans as new hosts due to their lost ecosystems. See David Harvey, »Anti-Capitalist Politics in the Time of COVID-r9, "Jacobin, March 20, 2020, https:// jacobinmag.com/2020/03/david-harvey-coronavirus-political-economy-dis ruptions; David Quammen, "We Made the Coronavirus Epidemic, "The New York Times, January 28, 2020, https:/www.nytimes.com/2020/or/28/opinion/ coronavirus-china.html.

30 Bradley J. Macdonald, Performing Marx: Contemporary Negotiations of a Living Tradition (Albany: State University of New York Press, 2006), 47-49.

3I In comparison, another famous scholar, Vandana Shiva argued similarly to Harvey. Although she did not explicitly base her writings on Marx's ideas, Shiva concluded that the coronavirus pandemic could not be separated from capitalistic logic, which sees nature as the raw material of production. Shiva presented evidence that the Ebola outbreak also occurred due to deforestation. Shiva, as an ecofeminist thinker, has made an argument for de-industrialization, especially for changes in the food system. See Vandana Shiva, "Ecological Reflections 
and subsequent human contact with this damaged nature allows the transfer of various viruses that were previously »isolated « from humans, one of which is the coronavirus..$^{32}$

Another analysis was conducted by Martin Suryajaya, ${ }^{33}$ who tried to underline the potential crisis of capitalism caused by the coronavirus. ${ }^{34}$ According to him, the coronavirus will encourage the creation of the lumpenproletariat. Its emergence would happen as a natural consequence of the policy that required the manufacturing industry to lay off hard work to prevent the spread of the coronavirus. The cessation of production for a long time will result in companies losing money and going out of business. In his analysis, Suryajaya believes this crisis will not only occur in the manufacturing industry but will widen to a variety of other industries that cannot be based on working from home, such as the entertainment industry. Along with the fall of various industries, the monetary system may also be destroyed if many people no longer invest their money but prefer to withdraw it to guard against uncertain situations for a long time. In short, the coronavirus outbreak has the potential to lead to a severe crisis of capitalism - although Suryajaya politely says that it is only a prediction and will not necessarily occur. ${ }^{35}$

Unfortunately, amid the popularity of the name Marx, it can be said there has been no serious effort from academics to elaborate Engels's thought in context to understand the coronavirus outbreak-at least, not as far as the search conducted by the author has shown. ${ }^{36}$

on the Coronavirus," Medium, March 23, 2020, https://medium.com/postgrowth-institute/ecological-reflections-on-the-coronavirus-93d5obbfe $9 \mathrm{db}$.

32 Harvey, "Anti-Capitalist Politics."

33 Martin Suryajaya is a young Indonesian thinker who is well known for his works on Marxism.

34 Martin Suryajaya, "Membayangkan Ekonomi Dunia Setelah Korona Atau Cerita tentang Dua Virus, "MartinSuryajaya.com, March 30, 2020, https://www. martinsuryajaya.com/post/membayangkan-ekonomi-dunia-setelah-korona.

35 Ibid.

36 There are various other critical analyses of the coronavirus outbreak with different emphases. Take, for example, Yasraf Amir Pilliang, a famous Indonesian post-modern thinker, who took inspiration from Paul Virilio to put forward an argument 
Amid the scarcity of Engels studies, this article tries to contextualize Engels's ideas for a better understanding of the coronavirus outbreak. Engels's thoughts on authority are essential to counter the post-truth tendencies that coincide with the global spread of epidemics. ${ }^{37}$ These post-truth tendencies have caused severe problems for humanity because the anti-authority biases inherent in the post-truth era make it difficult for humans to work together as a species to "wage war" against the coronavirus. ${ }^{38}$ At the same time, Engels also contributed to revealing another dangerous tendency where the anti-authority trend is faced with the logic of traditional authority based on the spirit of territorialism within the framework of the Westphalian state. ${ }^{39}$ The

for the de-globalization trend that occurred due to the outbreak. Other famous academics such as Naomi Klein, also known as an anti-capitalist activist, tried to see the outbreak as based on the ideas of shock doctrine and disaster capitalism. She tried to explain the symptom of the return of elite characters in this outbreak who manipulated people's fears to pass unpopular policies (leading to widening injustice, benefiting the elite, and harming ordinary citizens). Interestingly, Klein concluded that we should be wary of elite discourse and that citizens would be being selfish by staying quiet at home. Klein said we would never be safe if we did not help our neighbors because without them (for example, those who carry out the production process) our needs are also potentially in danger. The demands on the elite to enforce a policy that will cover all parties then become an inevitability. But once again, it needs to be emphasized that in the middle of an abundance of weighty analyses, academics who refer to Engels to analyze the coronavirus outbreak critically have not yet been seen. See Yasraf Amir Pilliang, „Virus De-Globalisasi, "Kompas, March 30, 2020, https://kompas.id/baca/opini/2020/o3/30/virusde-globalisasi/; Marie Solis, "Coronavirus Is the Perfect Disaster for $>$ Disaster Capitalism «, «Vice, March I3, 2020, https://www.vice.com/en_uk/article/5dmqyk/naomiklein-interview-on-coronavirus-and-disaster-capitalism-shock-doctrine.

37 Engels, "Versus the Anarchists, « 729.

38 The post-truth narrative cannot be separated from the spirit of anti-authority, especially authority in the mainstream sense (e.g. legal-formal authority). See Gabriele Cosentino, Social Media and the Post-Truth World Order (Cham, Switzerland: Springer, 2020), 8-9; Steve Fuller, Post-Truth: Knowledge As A Power Game (London: Anthem Press, 2018), Io.

39 Michael E. Clarke, Xinjiang and China's Rise in Central Asia-A History (Abingdon: Routledge, 20II), 3; Kal Raustiala, Does the Constitution Follow the Flag? The Evolution of Territoriality in American Law (Oxford: Oxford University Press, 2009), I0. 
tendency of the return of authority in the Westphalian sense also has the potential to cause various new problems. The conclusion that Westphalian logic is problematic is not an exaggeration, given the nature of Westphalian authority, which emphasizes potential territorial isolation (disengagement), hampering the possibility for global cooperation..$^{40}$ Furthermore, the application of a Westphalian style of authority raises the risk of the presence of an authoritarian state that considers that a single command lies in its hands and potentially eliminates other ideas that are deemed not to be under its command. ${ }^{4}$

On the other hand, the efforts to bring back Westphalian logic in our era will also potentially strengthen anti-authority tendencies in society. This trend, for example, is reflected in the Indonesian context where local governments - even citizens at the local level-choose to take actions that are different from the national government command line..$^{42}$ This phenomenon happened because they feel that the excessive domination of the central government is not followed by ef-

40 Interestingly, the WHO eventually revised the use of the term social distancing and turned it into physical distancing. The reason, as stated by Maria van Kerkhove, an epidemiologist working at the WHO, is that efforts to build a feeling of interconnection are essential for maintaining public mental health amid the epidemic. In other words, the WHO is aware that without robust global connectivity, efforts to fight the coronavirus will encounter major obstacles. See Harmeet Kaur, »Forget ,Social Distancing. ‘ The WHO Prefers We Call It `Physical Distancing Because Social Connections Are More Important Than Ever, CNN, April I8, 2020, https:/edition.cnn.com/2020/04/I5/world/social-distancing-languagechange-trnd/index.html.

4I Florian Bieber, "Authoritarianism in the Time of the Coronavirus, "Foreign Policy, March 30, 2020, https://foreignpolicy.com/2020/03/30/authoritarianismcoronavirus-lockdown-pandemic-populism/.

42 Jamal A. Nashr, »Tegal Lockdown karena Corona, Wali Kota: Tak Ditegur Mendagri,« Tempo, April 3, 2020, https://nasional.tempo.co/read/1327529/tegal-lock down-karena-corona-wali-kota-tak-ditegur-mendagri; Irwan Syambudi, »Lockdown Mandiri ala Jogja: Ditolak Pemerintah, Diinginkan Warga, «irto, March 27, 2020, https://tirto.id/lockdown-mandiri-ala-jogja-ditolak-pemerintah-diing inkan-warga-eH 30. 
fective policymaking in the face of the increasingly widespread coronavirus epidemic across Indonesian territory. ${ }^{43}$

This study will use the case of the global response to the coronavirus outbreak to elaborate on how the logic of anti-authority and authority in the traditional sense (Westphalian state) have emerged at the same time. It seeks to reflect on the circumstances of China, the US, Europe, Indonesia, and other cases deemed relevant. This study places Engels's thought as an analytical framework in which the coronavirus outbreak is interpreted as a post-truth outbreak. To deal with the posttruth coronavirus outbreak, we must enter into the discussion of the crisis of authority that has occurred globally, followed by efforts to find a new form of authority that would have the function of liberating humans from the threat of a coronavirus outbreak. Without realizing the importance of the axiological aspects of the existence of authority, as stated by Engels, the world will have a hard time facing this pandemic. ${ }^{44}$ Furthermore, what happens by choosing a non-liberating form of authority has the potential to give birth to new chaos amid humans race to face the coronavirus, which can develop quickly and is also known to be able to mutate. Without the search for accurate solutions amid diminishing time, humans existence as a species is at stake.

\section{Contextualizing Engels's Thought in the Coronavirus Crisis}

Before entering into the discussion of Engels's idea of authority when dealing with the coronavirus outbreak, we first need to understand his idea in more detail. This discussion is also important because Engels's idea of authority has been criticized by some academics and

43 The Jakarta Post, „COVID-19: Regions Start Locking Down as Govt Works on Regulation, "The Jakarta Post, March 28, 2020, https://www.thejakartapost.com/ news/2020/03/28/covid-I9-regions-start-locking-down-as-govt-works-on-regu lation.html.

44 Engels, »On Authority, « 732; Engels, »Versus the Anarchists, « 729. 
contemporary anarchist writers who feel that Engels's criticism of anarchists is inappropriate. ${ }^{45}$ This study argues that Engels's idea of authority, raised in the nuance of the debate between Marxists and anarchists, was not a misplaced criticism ${ }^{46}$ but rather a valid academic criticism. Engels tried to direct the debate over authority to the axiological side, and it can be said that this axiological side did not receive adequate discussion from anarchists. ${ }^{47}$

Although this study believes that Engels's criticism of anarchists positions can be justified, it must be acknowledged that anarchists positions remained useful in the debate about the idea of authority. Mikhail Bakunin's (18I4-1876) most important contribution to the debate over authority was bringing it into the ontological domain..$^{8}$

45 For example, academics such as Paul McLaughlin say that Marxist criticism of anarchists on authority is only based on prejudice, which tends to be simplistic and inaccurate. Anarchists, who write on a number of websites using pen names like Yuki, also say figures like Engels failed to understand the concept of anarchism about authority. Another article called "An Anarchist FAQ" labelled Engels's criticism of anarchists non-fundamental, accusing Engels of being ignorant and of not understanding what he criticized. See Paul McLaughlin, Anarchism and Authority: A Philosophical Introduction to Classical Anarchism (Aldershot: Ashgate, 2007), I2; Yuki, "The Semantical Issue Behind Engels's »On Authority« and How It Relates to Modern Day Anarchism, " The Anarchist Library, July I2, 2019, https://theanarchistlibrary.org/library/yuki-the-semantical-issue-behind-engelson-authority-and-how-it-relates-to-modern-day-anarchism\#fnI; The Anarchist FAQ Editorial Collective, "An Anarchist FAQ (09/17), " accessed April I, 2020, https://theanarchistlibrary.org/library/the-anarchist-faq-editorial-collectivean-anarchist-faq-09-I7.pdf.

46 Engels, "Versus the Anarchists, « 729.

47 Anarchists are more concerned with the ontological side of authority. See Saul Newman, From Bakunin to Lacan: Anti-authoritarianism and the Dislocation of Power (Lanham: Lexington Books, 200I), 25-26; David W. Lovell, From Marx to Lenin: An Evaluation of Marx's Responsibility for Soviet Authoritarianism (Cambridge: Cambridge University Press, 1984), 74.

48 It should be stated here that the views of famous thinkers such as Bakunin do not necessarily »bind " anarchists in general. This tendency can be seen as a manifestation of a strong anti-authority tendency among anarchists. So the ideas put forward by thinkers from Bakunin and Kropotkin to Proudhon cannot be considered as ideas that are fully accepted and shape the face of the anarchist movement as a whole. That is why it is also a question for academics and or anar- 
Bakunin's argument is right when he mentions the destructive potential of an authority that is considered positive by the Marxist (e.g. the concept of a proletarian state)..$^{49}$ Based on that concern, Bakunin tried to formulate an alternative to reduce the destructive potential of an authority. He then discusses a new form of authority based on the idea of "voluntary" to minimize the form of authority that has the potential to oppress individuals in the future. ${ }^{50}$ History proves that deviations of authority, previously believed by Marxists to be a liberating authority, occurred in the history of the Russian Revolution. ${ }^{\text {sI }}$ The Russian Revolution experienced corruption, especially in the Stalin era, which changed the proletarian state into a totalitarian state by placing Stalin as the absolute ruler in that country.52

The synthesis of Engels's and Bakunin's thoughts is also relevant if it is related to the discussion about the coronavirus outbreak. Before looking at the synthesis of Engels's and Bakunin's thoughts, it is

chist exponents who then blame Engels's criticism of the anarchist movement by describing the views of one of the leading anarchist thinkers, because it could be that the ideas of the thinkers on which they base their arguments were not fully agreed on by the anarchist movement in the days of Engels. See Richard T. De George, "Anarchism and Authority, « Nomos i9 (1978): 92.

49 Feigan, "Marx's "Dictatorship of the Proletariat, "Contemporary Chinese Thought 46, no. 2 (2015): 28.

50 Bakunin, "What is Authority?"

5I Leon Trotsky (I879-I940), one of the architects of the Russian Revolution, also had concerns like Bakunin that the revolution could experience symptoms of corruption. Trotsky saw that there was a potential similarity between the Russian Revolution and the French Revolution, which, despite its noble goals, ultimately led to the growth of the dictator Napoleon Bonaparte (I769-I82I). Trotsky's concern can be said to be reasonable. In the Stalin era, it seems that Russia turned into a kind of new empire that had control over its satellite states in Eastern Europe. See Jay Bergman, The French Revolutionary Tradition in Russian and Soviet Politics, Political Thought, and Culture (Oxford: Oxford University Press, 2019), 438-439.

52 An ironic historical fact is that Stalin (I878-1953), who had a major role in deviating the authority of the workers for his political interests, is an admirer of Engels's idea of authority-It is not surprising, then, that Stalin used Engels' thought as his main guide in arguing with anarchists. See Roland Boer, Stalin: From Theology to the Philosophy of Socialism in Power (Singapore: Springer, 2017), I20. 
necessary to understand the nature of this post-truth era, which is characterized by anti-authority. ${ }^{53}$ Why does a rejection of authority symbolize post-truth? To grasp this, we must understand the nature of post-truth and its effects on the global public. Post-truth, as emphasized by Oxford Dictionaries, is a marker of shifting public confidence from facts to personal opinions. ${ }^{54}$ The facts referred to here are facts obtained from the empirical method. 5 For example, statements that the Statue of Liberty exists in the US can be empirically verified by visiting the location of the statue. But there are also subjective interpretations of facts. Take, for example, the statement that the Statue of Liberty is an icon of the US. A different approach must be taken to verify this statement, because it cannot be checked empirically. The way to validate this statement is to look at the collective imagination of the global community. If it is proven that the citizens of the US and the world have a relatively similar vision - that the building is an icon of the US - , we can say that this statement can be declared valid. The subjective side of interpreting this reality is natural, related to the symbolic side inherent in human beings. ${ }^{56}$ However, the personal side of reality becomes problematic in the post-truth era due to the construction of imagination related to one fact, which tends to spread fear and excessive distrust of the "external world. "\$7

Take the example of the coronavirus, which first appeared in the territory of China, as far as experts have been able to verify. However, the presence of the virus in Wuhan was then given the subjective

53 Robert Farrow and Rolin Moe, »Rethinking the Role of the Academy: Cognitive Authority in the Age of Post-Truth, "Teaching in Higher Education 24, no. 3 (2019): 273 .

54 Wilson, »Pre-truth, Post-truth and the Present, « I54.

55 Saulo de Freitas Araujo, "Truth, Half-Truth, and Post-Truth: Lessons from William James, Journal of Constructivist Psychology [online] (February 2020), https://doi.org/IO.IO80/I0720537.2020.1727390.

56 Ibid.

57 Frank Fischer, "Knowledge politics and Post-Truth in Climate Denial: On the Social Construction of Alternative Facts, Critical Policy Studies 13, no. 2 (2019): I34-I35 
interpretation that the virus was a biological weapon belonging to China that had leaked out. ${ }^{8}$ It is true that the virus initially spread in the Wuhan region (which became the epicenter of the spread of the virus). ${ }^{59}$ It is also a fact that there is a virus research laboratory in Wuhan which has the official name of the Wuhan Institute of Virology. ${ }^{60}$ But it is become problematic when the events are arranged in the framework of the narrative of

fear. ${ }^{61}$ The fear narrative is increasingly "convincing " by showing images of the laboratory, the logo of which resembles that of the fictitious company "Umbrella Corporation" in the Hollywood films and video games titled Resident Evil, which is responsible for releasing viruses that turn humans into zombies. However, if one examines the image critically, the image that appears "convincing " turns out to be built on wild fantasies that are difficult to verify and some irrelevant data. ${ }^{62}$ The emergence of post-truth narratives that are difficult to check, such as this case, quickly spread through social media and

58 BBC, „China coronavirus: Misinformation spreads online about origin and scale, « $B B C$, January 30, 2020, https://www.bbc.com/news/blogs-trending-5I27I 037.

59 Huan Yang, Peng Bin and Alex Jingwei He, "Opinions from the Epicenter: An Online Survey of University Students in Wuhan Amidst the COVID-I9 Outbreak, "Journal of Chinese Governance 5, no. 2 (2020): 234-248; Yu, "Confronting and Governing the Public Health Emergency, « I37-I39

60 Emily Makowski, "Theory that Coronavirus Escaped from a Lab Lacks Evidence, "The Scientist, March 5, 2020, https:/www.the-scientist.com/news-opinion/theory-that-coronavirus-escaped-from-a-lab-lacks-evidence- 67229.

6I Molly Stellino, "Fact Check: Did the Coronavirus Originate in a Chinese Laboratory? «USA Today, March 22, 2020, https://www.usatoday.com/story/news/fact check/2020/03/2I/fact-check-did-coronavirus-originate-chinese-laboratory/288 II5000I/.

62 The laboratory logo that is claimed to be similar to the Umbrella Corporation logo is actually a logo of a laboratory in Shanghai named Shanghai Rulian Bao Hu San Biotech. So it would be naive for the logo in Shanghai to be used as a justification for the development of biological weapons in Wuhan. Further studies conducted on the laboratory in Shanghai also found no indication of biological weapons being developed. See Rachael Krishna, "This Company Is Based in Shanghai, not Wuhan, «Full Fact, January 30, 2020, https://fullfact.org/online/wuhan-residentevil-coronavirus/. 
affect the public at large, which then causes mass fear. In this context, anxiety and, at the same time, hatred of China emerged. ${ }^{63}$ The implications can be very complicated, such as the growth of racism towards Chinese people, which led to efforts to blockade their territory to avoid the "threat " of China. ${ }^{64}$ From this explanation, we can conclude that, starting with a post-truth narrative, it turns out to be possible to influence global politics. We can also find that the panic response is not much help because the coronavirus cannot be prevented from spreading globally just by closing off one particular territory. ${ }^{65}$ So, instead of the post-truth narrative contributing to saving the world, it opens the way for the virus to develop more quickly because China is left to struggle alone in facing the threat of the coronavirus. ${ }^{66}$ When China could no longer restrict the spread of the virus, it quickly spread to various other parts of the world, breaking through territorial boundaries that many imagined would be effective against the global spread of the virus. ${ }^{67}$

Based on the example above, we can see several anti-authority tendencies arising from the post-truth narrative about China. If we look at the WHO release, it is said that the spread of the virus should

63 Eoghan Macguire, "Anti-Asian Hate Continues to Spread Online Amid COVID-r9 Pandemic," Al Jazeera, April 5, 2020, https://www.aljazeera.com/ news/2020/o4/anti-asian-hate-continues-spread-online-covid-I9-pandemic-200 4050630I5286.html.

64 Lauren Aratani, "Coughing while Asianı: Living in Fear as Racism Feeds Off Coronavirus Panic, "The Guardian, March 24, 2020, https://www.theguardian. $\mathrm{com} /$ world $/ 2020 / \mathrm{mar} / 24 /$ coronavirus-us-asian-americans-racism.

65 Lucy Budd and Stephen Ison, "Air Travel Restrictions Won't Protect Us from the Coronavirus, "The Jakarta Post, February IO, 2020, https://www.thejakartapost. $\mathrm{com} / \mathrm{travel} / 2 \mathrm{O} 2 \mathrm{O} / \mathrm{O} 2 / \mathrm{Io} /$ air-travel-restrictions-wont-protect-us-from-the-coronavirus.html.

66 James T. Areddy, "Amid Coronavirus, the World Closes Its Doors to China: $I$ Feel So Isolated, « The Wall Street Journal, February I8, 2020, https://www.wsj. $\mathrm{com} /$ articles/amid-coronavirus-the-world-closes-its-doors-to-china-i-feel-so-iso lated-II5820608II.

67 Jessie Yeung, "A Global Coronavirus: Travel Bans, Face Masks, and Fear, "CNN, February 27, 2020, https://edition.cnn.com/2020/02/27/world/gallery/coronavi rus-prevention/index.html. 
not be used as a basis for racist action. ${ }^{68}$ However, WHO's authorities have been ignored by a number of parties. For example, in some European countries, there has been an increase in anti-Chinese sentiment. The rise of anti-Chinese sentiments in Europe is related to the spread of the post-truth idea that ethnic Chinese, in general, are "carriers" of the coronavirus. ${ }^{69}$ Likewise, global mistrust in the Chinese government authorities increased, which led to many countries taking action to isolate China. ${ }^{70}$ Yet it was precisely the isolation of China that essentially provided ample space for the coronavirus to multiply. The virus is able to multiply quickly, and thus relying on Chinese energy alone was not going to be enough to contain the spread of the deadly virus. So it is not surprising that Xi Jinping continued to push for global cooperation rather than shut down and the placing of suspicion on Chinese authorities. ${ }^{71}$ Antipathy toward Chinese authority and citizens does not provide much benefit in dealing with the threat of the virus. ${ }^{72}$

This strong anti-authority tendency, inherent in the post-truth era, is one of the reasons why the world has become so desperate while

68 Paula Larsson, "Anti-Asian Racism during Coronavirus: How the Language of Disease Produces Hate and Violence, "The Conversation, March 3I, 2020, https:// theconversation.com/anti-asian-racism-during-coronavirus-how-the-languageof-disease-produces-hate-and-violence-I34496.

69 Kung Phoak, "Stop Prejudice, the Novel Coronavirus Has no Race, "The Jakarta Post, February 22, 2020, https:/www.thejakartapost.com/academia/2020/02/22/ stop-prejudice-the-novel-coronavirus-has-no-race.html.

70 Leslie Josephs, "China Grows Isolated as Airlines Cancel More than 50,000 Flights Amid Coronavirus Epidemic, « $C N B C$, February 6, 2020, https://www. cnbc.com/2020/02/06/coronavirus-china-becomes-increasingly-isolated-as-air lines-pull-out.html.

7I Stuart Lau and Owen Churchill, "Xi Jinping Urges 'Stronger International Cooperation` and Quick Action to Fight Coronavirus Pandemic and Stave Off Global Recession, "South China Morning Post, March 26, 2020, https://www. scmp.com/news/china/politics/article/3077174/xi-jinping-urges-stronger-inter national-cooperation-and-quick.

72 Mara Pillinger, „Virus Travel Bans Are Inevitable But Ineffective, «FP, February 23 , 2020, https://foreignpolicy.com/2020/O2/23/virus-travel-bans-are-inevitable-butineffective/. 
facing the coronavirus outbreak. This statement does not mean that if this outbreak happened in the context of a »normal« era, the world could quickly solve this problem. However, this post-truth situation naturally complicates global cooperation..$^{73}$ Global cooperation is the key to fighting a pandemic that does not recognize territorial logic, including gender and certain social classes. In other words, humans are weakening their position amid the threat of this deadly plague if they continue to maintain their anti-authority logic that impedes global cooperation. ${ }^{74}$

However, it is also interesting to realize that the emergence of the post-truth era also brought strong sentiments about restoring "traditional " authority. ${ }^{75}$ This desire for resurrecting "traditional " authority can be traced back to long before this outbreak began. There is a growing trend in the academic world that seeks to resurrect "traditional" authority, such as the authority of scientists, as a solution to the post-truth era. ${ }^{76}$ So what is happening today where there is a desire to strictly re-enforce Westphalian territorial logic, is a manifestation of a long-standing desire to restore the "traditional " authority that has been marginalized due to the rising tide of the post-truth era. The desire to turn back history by positioning traditional authority as an answer to overcoming the post-truth problem can be said to be problematic. To say that there are problems inherent within the desire to resurrect "traditional" authority is not an exaggeration because reality shows that the closing of borders between one country and another does not prevent the spread of the virus in countries that are trying to isolate themselves. ${ }^{77}$ In the context of finding solutions, the synthesis of Engels's and Bakunin's ideas could be an alternative

73 Harari, "In the Battle Against Coronavirus."

74 Ibid.

75 Fischer, »Knowledge Politics, « I35-I36.

76 Ibid.

77 Noah Higgins-Dunn, »Travel Restrictions `Irrelevant` if Coronavirus Becomes a Pandemic, Top US Health Official Says, « CNBC, February 26, 2020, https:// www.cnbc.com/2020/02/26/fauci-travel-restrictions-irrelevant-if-coronavirusbecomes-a-pandemic.html. 
that transcends the »traditional « logic of territorialism and also offers a form of authority that encourages human cooperation at all levels. ${ }^{78}$ Engels's concept of authority cannot be separated from the prolonged debate between Marxists and anarchists. ${ }^{79}$ Marx, who at that time became an intellectual defender of Marxism, faced one of the giant intellectuals of the anarchists, Bakunin. ${ }^{80}$ Both Marx and Bakunin believed that capitalism was an oppressive system, and they agreed that revolution was the starting point for changing current harsh orders ${ }^{81}$ But despite these similarities, both had different philosophical foundations that made them argue about some fundamental problems, one of which is authority. ${ }^{82}$

Bakunin was an intellectual who grew up in a tradition of empiricism that recognizes the supremacy of experience over abstract concepts. ${ }^{{ }_{3}}$ Bakunin was also an intellectual who was influenced by the philosophy that emphasizes the idea of a "state of nature. $\varkappa^{84}$ The idea of a "state of nature " envisions a primitive human era that tends to be good but then experiences degradation due to the concept of

78 This study agrees with Emma Woods that post-truth cannot be confronted by reviving "traditional« authority but instead by devising a new form of authority that is more dynamic, open, and dialogic. Specifically, Woods believes that scientific authority must be transformed in such a way as to make it more open to public criticism. In line with Woods, this study believes that the authorities based on Westphalian logic are not adequate to fight the coronavirus outbreak. A new form of authority that is more nuanced in universal human interconnection is needed, and this would also open up a broad range of movements for individuals that are needed to deal with the pandemic. See Emma Woods, "Science Policy in a Post-Truth World, « in Risk and Uncertainty in a Post-Truth Society, ed. Sander van der Linden and Ragnar E. Löfstedt (Abingdon: Routledge, 20I9), 4I.

79 Newman, From Bakunin to Lacan, I7.

80 Paul McLaughlin, Mikhail Bakunin: The Philosophical Basis of His Theory of Anarchism (New York: Algora Publishing, 2002), 96.

8I Eric Voegelin, From Enlightenment to Revolution (Durham: Duke University Press, 1975), 20I.

82 Newman, From Bakunin to Lacan, 17.

83 McLaughlin, Mikhail Bakunin, II3.

84 Barbara Goodwin, Using Political Ideas (Chichester: John Wiley \& Sons, Ltd., 2007), I33. 
organized society, especially in the era of capitalism. ${ }^{85}$ Interestingly, Bakunin did not take the idea of "state of nature " wholeheartedly because he agreed with Marx that the fundamental phase of humanity was a primitive society era where humans lived in communality but still maintained their autonomy. ${ }^{86}$ Primitive society for Bakunin was a society that naturally existed because individuals needed each other, but in which there was no attempt by one party to dominate another. ${ }^{87}$ He believed that there was no domination in primitive communist society because there was no "external « authority capable of influencing individual movements. ${ }^{88}$ Individual autonomy remains a fundamental thing in Bakunin's thought about freedom. ${ }^{89}$ For Bakunin, the ideal of revolution is the desire to return man to his primitive state. ${ }^{\circ}$ From this desire, it can be concluded that Bakunin considers that the concept of authority is naturally problematic..$^{\text {I }}$ The spontaneity of life and cooperation is the key and not the "imposed authority/external authority," which is the key to overcoming the problem of contemporary human oppression. ${ }^{92}$ His view about the spontaneity of life makes Bakunin and other anarchists uncomfortable with the concept of the proletarian dictatorship echoed by Marx.93

85 Samuel Rezneck, "The Political and Social Theory of Michael Bakunin, "The American Political Science Review 2I, no. 2 (1927): 280-28I.

86 John Morrow, History of Western Political Thought (London: Red Globe Press, 2019), 9I.

87 Rebecca A. Martusewicz, "'All this Boundless Multitude:^ Rereading Mikhail Bakunin for EcoJustice Education, "Educational Studies 48, no. I (2012): I-2.

88 William L. Remley, Jean-Paul Sartre's Anarchist Philosophy (London: Bloomsbury Academic, 20I8), 8I-82.

89 McLaughlin, Anarchism and Authority, I9.

90 Leon P. Baradat, Political Ideologies: Their Origins and Impact (Abingdon: Routledge, 2016), I52.

9I Lawrence Wilde, Global Solidarity (Edinburgh: Edinburgh University Press, 2013), 29.

92 Martin Phillip Johnson, The Paradise of Association: Political Culture and Popular Organizations in Paris Commune of I87I (Ann Arbor: The university of Michigan Press, 1996), 278.

93 Lyman Tower Sargent, "Mikhail Bakunin (18I4-76), " in Encyclopedia of Nineteenth-century Thought, ed. Gregory Claeys (Abingdon: Routledge, 2005), 32. 
Unlike Bakunin, Marx grew up in a Hegelian tradition. ${ }^{94}$ Marx acknowledged that the primitive society era was a classless society.95 Still, according to dialectical law, there was a process of community development that led to the idea of individual ownership. ${ }^{96}$ Historical movements continued until the era of capitalism, which for Marx was an era of humans exploitation of other humans. ${ }^{97}$ But unlike Bakunin, Marx viewed capitalism as not entirely evil..${ }^{8}$ Even Marx saw the bourgeoisie as revolutionaries of his time ${ }^{99}$ because, at that time, the worker was not in a state of being aware of his class consciousness. ${ }^{100}$ Capitalism, in its turn, will open the consciousness of the working class because of the alienation effect produced by the system. ${ }^{\text {Ior }}$ In the end, the workers will carry out a revolution and then create a communist society, which is the end of the dialectics of history. ${ }^{\text {I02 }}$

Unlike Bakunin's position, Marx felt that history was moving forward and not backward. ${ }^{103}$ Marx also felt that because the foundation

94 Norman Levine, "Hegelian Continuities in Marx, Critique 37, no. 3 (2009): 346-370.

95 Marian Sawer, Marxism and the Question of the Asiatic Mode of Production (The Hague: Martinus Nijhoff, I977), 2II-2I2.

96 Simon Clarke, Marx, Marginalism and Modern Sociology: From Adam Smith to Max Weber (Aldershot: Macmillan Academic, 1991), 59.

97 William Clare Roberts, Marx's Inferno: The Political Theory of Capital (Princeton, NJ: Princeton University Press, 2017), I27.

98 Chilla Bulbeck, Re-orienting Western Feminisms: Women's Diversity in a Postcolonial World (Cambridge: Cambridge University Press, 1998), I9.

99 R. J. Holton, The Transition from Feudalism to Capitalism (New York: St. Martin's Press, 1985), I89.

Ioo Elliott Johnson, David Walker and Daniel Gray, Historical Dictionary of Marxism (Lanham: Rowman \& Littlefield, 20I4), 8I.

IOI I. Fetscher, "Karl Marx on Human Nature, in Karl Marx's Economics: Critical Assessments, ed. John Cunningham Wood (London: Routledge, I998), 220.

IO2 Fred Moseley and Tony Smith, "Introduction, " in Marx's Capital and Hegel's Logic: A Reexamination, ed. Fred Moseley and Tony Smith (Leiden: Brill, 20I4), I.

IO3 Huaiyin Li, "Rewriting Modern Chinese History in the Reform Era: Changing Narratives and Perspectives in Chinese Historiography, " in Marxist Historiographies: A Global Perspective, eds. Q. Edward Wang and Georg G. Iggers (Abingdon: Routledge, 2016), 95. 
was class consciousness, so the state could be used for the sake of class struggle as well. ${ }^{104}$ Marx suggests that the state (which in the modern framework is attached to formal legal authority) can be used for the benefit of workers, especially in the transition to socialism. ${ }^{\text {Ios }}$ So even though Marx does not explicitly elaborate on the concept of authority, he does not consider authority in the sense of "external authority" to be a problem. ${ }^{106}$ Marx also stated that class consciousness needs to be formed before the revolution. ${ }^{107}$ In other words, he considers the idea of the "state of nature " that Bakunin believed was inaccurate because "naturally" they (the workers) did not have class consciousness, so they had to become "aware " by learning. ${ }^{108}$ Unlike Marx, Bakunin believed in spontaneity rather than the indoctrination of "abstract concepts " by an external actor as the key to revolution. ${ }^{\text {109 }}$

Engels entered the debate between Marxism and anarchism by trying to strengthen the argument of Marxism. ${ }^{\text {I0 }}$ Engels also raised the discussion about authority as a new academic debate. He felt that if the issue of authority were not cleared up first, various discussions about the revolution, the state, and so on would become endless de-

IO4 Newman, From Bakunin to Lacan, 27-28.

IO5 David Pavon-Cuellar, Marxism and Psychoanalysis: In or Against Psychology? (Abingdon: Routledge, 2017), 7I.

I06 Paul Thomas, Karl Marx and the Anarchists (Abingdon: Routledge, 2010), I6.

IO7 Joseph M. Schwartz, The Permanence of the Political: A Democratic Critique of the Radical Impulse to Transcend Politics (Princeton, NJ: Princeton University Press, I995), I50-152.

I08 Timothy Messer-Kruse, The Haymarket Conspiracy: Transatlantic Anarchist Networks (Urbana, IL: University of Illinois Press, 20I2), 34.

Io9 Nathan Jun, "Anarchism and Just War Theory, " in Comparative Just War Theory: An Introduction to International Perspectives, eds. Luis Cordeiro-Rodrigues and Danny Singh (Lanham, MD: Rowman \& Littlefield, 2020), 23-24.

IIO Engels's analysis completes the position of Marx, who believes that it is not authority but an oppressive form of authority that must be rejected. Marx imagined that a new form of emancipatory authority would come along with the proletarian revolution. The difference is that Marx talks about the future, while Engels talks about the nature of authority by bringing it into the philosophical realm. See Peter Lamb, Marx and Engels's Communist Manifesto (London: Bloomsbury, 2015), 97. 
bate. ${ }^{\text {III }}$ For Engels, when discussing authority, we must speak in terms of an axiological realm. ${ }^{\text {I2 }}$ Engels argued that authority could not be reduced to merely a form of evil. An authority that has a liberating vision is an authority worth supporting. ${ }^{\mathrm{II} 3}$

Engels gave the simple example of a ship sinking in the middle of an ocean. ${ }^{\text {II4 }}$ Without apparent authority, all the passengers on the ship could drown. ${ }^{\text {II }}$ The authority, which has the function of liberating, becomes crucial to ensure the safety of the ship's passengers. ${ }^{\text {I16 }}$ So for Engels, the discussion about authority must start from its function and then discuss its form. This form adjusts according to the liberating function to be achieved. In the case of a ship that is threatened with sinking, passenger survival is a fundamental idea that forms the basis of the joint motion of the passengers. From the discovery of this specific function, Engels gives the example that there must be exceptional leadership that is obeyed by all passengers of the ship. ${ }^{\text {II7 }}$ Engels talked about someone who had sufficient leadership capacity so that all passengers would not be in a panic and take various irrational actions, such as throwing themselves into the sea, which would be an act of suicide. The existence of this one command is crucial to regulating passenger movements. No passenger may act to violate his

III Barry Hindess, "Socialism, Communism, Anarchism, " in Edinburgh Companion to the History of Democracy, eds. Benjamin Isakhan and Stephen Stockwell (Edinburgh: Edinburgh University Press, 2012), 350-35I.

II2 According to Herbert Marcuse (I898-I979), Engels did not want the abolition of authority but to transform it into a democratic form. In other words, Engels talks about the axiological realm where the purpose of authority is what must be addressed rather than imagining authority as an evil concept, which then necessitates erasing the idea of authority. See Paul Blackledge, Friedrich Engels and Modern Social and Political Theory (Albany: State University of New York Press, 2019), I47-I48.

II3 Engels, "On Authority, " 732-733.

II4 Ibid, 732 .

IIs Ibid.

II6 Ibid.

II7 Ibid. 
orders in order that all human resources on the ship can be utilized optimally for the safety of all of them. ${ }^{\mathrm{II}}$

The example used by Engels is interesting because it is related to several dimensions, namely binding concepts together, leadership, and obedience. ${ }^{\text {II }}$ Without these three dimensions of authority, we can be sure the ship will sink. In other words, it is not spontaneity but a rationally planned work (concept-based) that becomes important. ${ }^{\text {I20 }}$ Engels attempted to refute Bakunin's position and those who agreed with him by asserting that authority was a necessity if he wanted freedom or safety from danger. ${ }^{\text {.2I }}$

For Engels, authority is a matter of axiology. If authority is based on the idea of liberating, then it becomes valid, but if it is not, then it is rejected. ${ }^{122}$ From Engels's explanation, it can also be drawn that "shared concepts" are essential because these are the fundamental dimension of liberating authority. ${ }^{123}$ Based on these shared concepts, a contextual strategy can be designed depending on the mission it intends to carry out.

Engels's contribution to the debate over authority deserves appreciation. But the position of anarchists, especially Bakunin, is not entirely wrong. Bakunin's concept, which is based on spontaneity, if used in the context of saving a ship from the possibility of sink-

II8 Ibid.

II The three dimensions of liberating authority are not explicitly stated by Engels in his article, but are provided here to make it easier for the reader to understand Engels's explanation of the concept.

I20 Lenin agreed to Engels's idea of authority and tried to add his argument that without centralized coordination and based on rational planning, it would be impossible for a factory to produce, or for ships to sail smoothly at sea. In other words, Lenin underlines the issue of rational planning and not spontaneity as the key to the success of the workings of an order. See George G. Brenkert, Political Freedom (London: Routledge, 1991), I66.

I2I Daniel E. Saros, Information Technology and Socialist Construction: The End of Capital and the Transition to Socialism (Abingdon: Routledge, 20I4), 29.

I22 Stanislaw Ehrlich, Pluralism On and Off Course (Oxford: Pergamon Press, I982), I48.

I23 Engels, »On Authority, « 732-733. 
ing, may end in chaos because there are no big ideas that frame the movement of the passengers. ${ }^{24}$ However, the example given by Engels about a single form of leadership that tends to be personalistic is an unhealthy tendency. ${ }^{125}$ It could be said that Engels did not pay too much attention to how a liberating idea, if wrongly applied, could lead to disaster too. ${ }^{126}$ The ontological aspect of authority does not get much attention from Engels.

Interestingly, anarchist thinkers like Bakunin elaborate on the ontological side that was forgotten by Engels, so the ideas they put forward deserve serious attention as well. Bakunin's idea of "voluntary authority" and also the idea of the spontaneity of the masses can be used as inspiration to develop Engels's ideas. ${ }^{127}$ Contemporary anarchist intellectuals have tried to further develop Bakunin's ideas about "voluntary authority" and also made efforts to maintain the spontaneity of the masses within a broad framework of decentralized networks. ${ }^{\mathrm{I} 28}$

The concept of liberating authority developed by Engels coupled with positive criticism from Bakunin about the »voluntary« side and spontaneity can be synthesized in the context of being an alternative offer in the global war against the coronavirus. This study offers the interpretation of a discursive form of authority so that the fundamental of authority is a shared idea that guides human motion. ${ }^{129}$

I24 Ibid, 732 .

I25 Ibid.

I26 In Bakunin's thought, it is not justified to assume that there is an infallible authority on whom a person always relies. Bakunin proposed maintaining criticism of authority, for example, by asking questions of different health experts and thereby relate to the authority of health science as a whole so as not to rely on just one expert's opinion, which could be wrong. See Peter Marshall, Demanding the Impossible: A History of Anarchism (Oakland: PM Press, 20Io), 294.

I27 Bakunin, "What is Authority?»

I28 Jeff Shantz, Constructive Anarchy: Building Infrastructures of Resistance (Farnham: Ashgate, 2010), I9.

I29 The term discursive authority is inspired by Marcuse's reading of Engels whereby authority does not have to mean bad. Marcuse himself formulated the idea of rational authority, which, according to him, was necessary to ensure the suffi- 
The shared idea that was implied is the idea of human survival as a species. ${ }^{130}$ The idea of humans as a species is crucial to be encouraged because, in the context of the coronavirus outbreak, it is necessary to realize that this virus is not targeting a particular country, gender, civilization, race, or social class. ${ }^{\mathrm{I} I}$ Global collaboration must be built on the idea of the unity of human beings as a species. ${ }^{132}$ The contextualization of strategies relevant to this post-truth era must be designed from the idea that human beings must work together as a species.

This study argues network-based cooperation is a promising alternative. ${ }^{133}$ This collaborative network must also provide space for spon-

ciency of a civilization. Interestingly, the concept of rational authority developed by Marcuse is one based on knowledge-based authority. This study considers that knowledge-based authority necessitates an emancipatory discourse that could be an ultimate reference to ensure the survival of the current human civilization from its potential extinction due to the threat of the coronavirus outbreak. See Christopher Holman, Politics as Radical Creation: Herbert Marcuse and Hannah Arendt on Political Performativity (Toronto: University of Toronto Press, 2013), 83

I30 Anna Carthaus, „Yuval Noah Harari on COVID-I9: , The Biggest Danger Is Not the Virus Itself^« $D W$, April 22, 2020, https://www.dw.com/en/virus-itself-is-notthe-biggest-danger-says-yuval-noah-harari/a-53195552.

I3I Zizek gives an interesting illustration that the ethics of global cooperation must be encouraged, like the ethics of treating a soldier injured badly during a war. Although he/she is unlikely to recover, maximum effort is made to help the wounded soldier. Soldiers can be compared to humanity as a species that is at war with the coronavirus. No matter the kind of soldier (or their background), they must be saved because the existence of one soldier is crucial in the success of the war against the coronavirus. See Slavoj Zizek, "Barbarism with a Human Face," Welt, March I9, 2020, https://www.welt.de/kultur/literarischewelt/article2068292 59/Slavoj-Zizek-on-Corona-Barbarism-with-a-Human-Face.html.

I32 Yuval Noah Harari, "Yuval Noah Harari: The World After Coronavirus, "Financial Times, March 20, 2020, https://www.ft.com/content/19d90308-6858-IIea-a3 c9-Ife6fedcca75.

I33 An interesting inspiration can be obtained from the work of Peter Kropotkin (I842-I92I), one of the leading anarchist thinkers besides Bakunin, who also stressed the need to develop an organization with network characteristics. Kropotkin gave an example of a charity called the Royal National Lifeboat Institution, which is based on collective work but without the need for organizational centrality. See Andrew Whitworth, Information Obesity (Oxford: Chandos Publishing, 2009), I4I. 
taneous movements. Spontaneity does not mean that a person moves at will without the guidance of one particular big idea (i.e. the survival of the human species). ${ }^{134}$ Spontaneity must be interpreted such that there is room for each individual to develop their own methods in the fight against the coronavirus. ${ }^{135}$ With the opening of the space of spontaneity, various ideas that were previously unthinkable can be raised. ${ }^{136}$ It is these creative ideas generated from various parties that have significantly contributed to human survival on a macro level. ${ }^{137}$

I34 The spontaneous movement of the masses must be framed together with one big idea, namely the survival of humanity as a species. It is in this context that the idea of authority must inevitably exist, but in the form formulated by Engels and Marcuse, namely liberating discursive authority. See Engels, „On Authority, « 732; Holman, Politics as Radical Creation, 83.

I35 In the language of Emma Goldman (I869-I940), an American anarchist, free space must be provided so that individuals are allowed to "do it their own way." See Colin Ward, Anarchism: A Very Short Introduction (Oxford: Oxford University Press, 2004), 68.

I36 Herbert Read (I893-1968), a British literary critic and also an anarchist, argued that spontaneity is closely related to creativity. Using the framework of Fromm's psychology, Read stated that the effort to discipline spontaneity is what makes a society "sick, " and to "make it healthy" again, spontaneity must be given a large space so that a variety of creativity can be fostered. In the context of the war against the coronavirus, if the authority that works tends to be monolithic, it has the potential to destroy the brilliant ideas that are potentially emerging from the community. See Carissa Honeywell, A British Anarchist Tradition: Herbert Read, Alex Comfort and Colin Ward (New York: Continuum, 20II), 65.

I37 According to Harari, global information sharing is vital to ensure the survival of humanity. Harari exemplifies how it is crucial for every individual to have proper scientific knowledge on how to prevent the transmission of the coronavirus so that he can act appropriately. The problem for Harari that is happening right now is the closure of information rather than information disclosure. If Harari accuses, for example, some politicians of trying to block valid information from spreading, it can also be added that the traditional authority model based on territorialism is not conducive to the free flow of information globally. Instead, the network model offered in this study can be an alternative to ensure that the free flow of information can occur smoothly. The information in question is not just related to technical information to prevent transmission of the coronavirus but also inspirational information that can inspire people in various parts of the world to be encouraged to carry out humanitarian actions. See the UNESCO Courier, "Yuval Noah Harari: `Every Crisis Is Also an Opportunity`, "The UNES- 
The logic of the collaborative network that gives room to spontaneity is also expected to reduce the post-truth effect because no dominant authority is allowed in the logic of the network. ${ }^{138}$ In the context of avoiding the dominance of one party, it is necessary to contextualize the idea of Engels, especially on aspects of leadership and obedience. ${ }^{139}$ This study argues that leadership is not necessarily singular but can be plural. ${ }^{140}$ An essential component of leadership also lies not in its command abilities but in the ability to inspire other individuals. ${ }^{14 \mathrm{I}}$ The redefinition of leadership as an entity that can be a source of inspiration also changes the meaning of obedience. Obedience is not interpreted as blind submission but becomes the ability to capture inspiration and give birth to positive new inspiration. ${ }^{\mathrm{I} 2}$ So in this leadership context, for example, the position of experts such as the WHO is positioned as an essential source of inspiration on how to fight viruses based on scientific methods. ${ }^{143}$ This inspiration inspired some community members who then took the initiative to produce masks and sell them cheaply to prevent a scarcity. ${ }^{\text {I44 }}$ Other communities, such as religious or social movements, took the initiative to buy masks and distribute them to the poor so they could get

CO Courier, accessed April 30, 2020, https://en.unesco.org/courier/news-viewsonline/yuval-noah-harari-every-crisis-also-opportunity.

I38 Bakunin, "What is Authority?"

I39 Engels, "On Authority, " 732-733.

I40 McLaughlin, Anarchism and Authority, I58; Joyce Rothschild and J. Allen Whitt, The Cooperative Workplace: Potentials and Dilemmas of Organisational Democracy and Participation (Cambridge: Cambridge University Press, 1989), I6-I7.

I4I Nunzio Pernicone, Italian Anarchism, I864-I892 (Princeton, NJ: Princeton University Press, 1993), 290.

I42 Jeffrey Shantz and Dana M. Williams, Anarchy and Society: Reflections on Anarchist Sociology (Leiden: Brill, 2013), 45-56.

I43 BBC, "Virus corona: Tips terlindung dari Covid-I9 dan mencegah penyebaran sesuai petunjuk WHO, «BBC, April 2, 2020, https://www.bbc.com/indonesia/ dunia-52I27080.

I44 Ahmad Sukirno, "Komunitas Difabel Boyolali Bikin Masker untuk Warga Miskin, "rri.co.id, April 8, 2020, http://rri.co.id/post/berita/8I6848/daerah/komuni tas_difabel_boyolali_bikin_masker_untuk_warga_miskin.html. 
extra protection without spending money. ${ }^{145}$ Inspirational work based on network logic, for example, has occurred in many parts of Indonesia. Similar work may also have occurred in many other countries. What should be encouraged is to increase such inspirational work in the future.

\section{Conclusion: Engels's Discursive Authority or the Extinction of Humans as a Species}

One conclusion that can be drawn from this study is the importance to rethink the definition of authority to deal with the coronavirus outbreak. Engels explained that authority was inevitable in ensuring the survival of humanity. Without an acknowledgment of liberating authority, this global coronavirus outbreak will spread without significant obstacles. The virus has become unstoppable due to the fertile post-truth ground, which makes it difficult for humans to develop a joint strategy that is effective in dealing with the coronavirus threat. Post-truth narratives are built by manipulating the subjective side of human beings in interpreting reality. The subjective side of humanity is bombarded with narratives that are difficult to verify and often contain disinformation. The attacks result in public panic and, at the same time, reinforce a sense of distrust in all forms of authority.

What followed was a revival of extreme individualism that affected not only individuals but also communities and even nation-states. It is this extreme individualism that then leads to, for example, embarrassing events such as when the US was accused by some French and German officials of stealing a shipment of masks bound for France

I45 Muhammadiyah, "MCCC Denpasar Bagikan Iooo Masker Kepada Warga Kota Denpasar, "Muhammadiyah, April Io, 2020, http://www.muhammadiyah.or.id/ id/news-I8793-detail-mccc-denpasar-bagikan-Iooo-masker-kepada-warga-kotadenpasar.html; Makhfud Syawaludin, "NU Kabupaten Pasuruan Segera Bagikan 50 Ribu Masker Kain, "NU Online, April II, 2020, https://www.nu.or.id/post/ $\mathrm{read} / \mathrm{II} 8950 /$ nu-kabupaten-pasuruan-segera-bagikan-50-ribu-masker-kain. 
and Germany amid the rise of the "global war for masks. $\aleph^{146}$ All countries try to prioritize themselves with irrational actions. So Engels's idea of liberating authority becomes a promising alternative to prevent the world from falling into chaos and global barbarism.

This concept of liberating authority offered by this study is an idea developed by Engels (and also enriched by Bakunin's ideas) is authority in the discursive sense, not authority held by a particular institution. Authority in the discursive sense must be interpreted as a shared idea (big narrative) about the survival of humans as a species. In other words, humanism became the highest authority in the war against the coronavirus. Humanism here is not interpreted abstractly but very specifically, namely as our survival as a species. It is this acceptance of the grand narrative of humanism that forms the foundation for building trust globally. The meaning of this kind of authority will also prevent the accumulation of power in an institution such as the ruling regime in a particular country, which tends to be corrupt.

The discursive authority will prevent the public from blind obedience to any form of "small« authority within its sphere. The public will see the "small" authority, such as an expert organization like the WHO, as one entity that has an essential role in leadership against the coronavirus. But as necessary as the role of WHO leadership may be, for example, it cannot hold leadership alone and must be helped by other forms of leadership. In this new framework, everyone can and must take a leadership role because without their contribution (in any form), this global war will not be successful. Everyone can be likened to musicians in a musical performance in which each person plays a different role (producing different sounds through different musical

I46 Tim Lister, Sebastian Shukla and Fanny Bobille, "Coronavirus Sparks a ,War for Masks` as Accusations Fly, CNN, April 3, 2020, https://edition.cnn.com/ 2020/04/o3/europe/coronavirus-masks-war-intl/index.html; Kim Willsher, Julian Borger and Oliver Holmes, „US Accused of `Modern Piracy` After Diversion of Masks Meant for Europe, "The Guardian, April 4, 2020, https://www. theguardian.com/world/2020/apr/o3/mask-wars-coronavirus-outbidding-de mand. 
instruments). But it is precisely from the variations in sounds that cause a distinct beauty to arise and that makes music concerts meaningful. The unity of sound gives birth to musical tunes and makes the audience feel comfortable.

Leadership here is not meant as a sign of dominance because leadership is not inherent but an action that can be done by anyone. So we can say leaders like Duterte, who is threatening to shoot Filipinos who protest against his lockdown policy, are unacceptable in this kind of discursive authority scheme. ${ }^{147}$ Such an attitude does not give birth to a positive impulse to further strengthen cooperation among Filipinos but rather weakens trust among them, especially toward their government.

Engels's thought about discursive authority could be a reasonable solution and should be encouraged by academics as a new form of global cooperation. Without a change on the paradigmatic side, we are allowing the virus to win against humans. Take the lessons of China, for example, where an effort to concentrate authority in the central government in Beijing under Xi Jinping's command ultimately slowed down the detection and handling of the virus. Although China has since halted the spread of the virus in the country, the distrust that emerges from Chinese citizens has not stopped. Citizens` anger over the death of doctor Li Wenliang, for example, is proof of the logic of "traditional « authority, which had become the dominant paradigm in China to stem the spread of the coronavirus, causing many problems..$^{148}$

I47 Yuki Tsang, "'Shoot Them Dead : Philippine President Duterte Warns Coronavirus Lockdown Violators, « South China Morning Post, April 2, 2020, https://www. scmp.com/video/coronavirus/3078165/shoot-them-dead-philippine-presidentduterte-warns-coronavirus-lockdown.

I48 BBC, "Li Wenliang: Coronavirus Death of Wuhan Doctor Sparks Anger, «BBC, February 7, 2020, https://www.bbc.com/news/world-asia-china-5I40980I; Josephine Ma and Jun Mai, "Death of Coronavirus Doctor Li Wenliang Becomes Catalyst for ’Freedom of Speech Demands in China, « South China Morning Post, February 7, 2020, https://www.scmp.com/news/china/politics/article/3049606/ coronavirus-doctors-death-becomes-catalyst-freedom-speech. 
President Xi was forced to go to Wuhan himself, which can be interpreted as an apology to its citizens. ${ }^{\text {I49 }}$

The application of the logic of »traditional « authority based on territorial logic is still affecting China - to a greater or lesser degree — since the outbreak began to be controlled. Some residents — and also some police-affected by territorial logic rejected the government's attempt to open the border between Wuhan (Hubei Province) and neighboring regions (e.g. Jiangxi Province). ${ }^{\text {Iso }}$ This event means that despite the ongoing formation of a new consciousness based on the discursive idea of human survival as a species (which gained momentum with the "Wuhan Jiayou" phenomenon $\left.{ }^{15 I}\right)$, the new awareness process is

I49 Simon Tisdall, "Covid-I9 Is Exposing the Frailty in Autocrats and Democrats Alike, "The Guardian, March 15, 2020, https://www.theguardian.com/commentis free $/ 2020 / \mathrm{mar} / \mathrm{I} 5 /$ covid-I9-exposing-frailties-autocrats-democrats-alike-trumpxi-eu-un.

I50 Lea Li, "Police, Public Clash as Border Reopens Between Coronavirus Epicentre Hubei and Jiangxi Province, "South China Morning Post, March 29, 2020, https:// www.scmp.com/video/china/3077466/police-public-clash-border-reopens-be tween-coronavirus-epicentre-hubei-and.

I5I The phenomenon of "Wuhan Jiayou « is marked by Wuhan residents screaming from their apartment or residence, to which other residents respond with replies containing a message of unity and cooperation. The term "Wuhan Jiayou" means "Wuhan residents, get excited." It is a message to fellow Wuhan residents to work together to get through the crisis. This moment of togetherness later inspired some Wuhan residents to document the event and spread it via the Internet. Those who circulated it on the Internet can be said to have performed a leadership function because they were trying to inspire the world with the event they were experiencing in Wuhan. This message can be said to affect many parties. Many countries are also encouraged to take part in helping Wuhan and China overcome the coronavirus outbreak. The Chinese government also realized that their "traditional« way was not sufficient, even though they continued to act according to the "old « logic. The Chinese government then gave more leeway for the spirit of "Wuhan Jiayou " to be spread wider and globally. It should be noted that several buildings in China turned on lights to read "Wuhan Jiayou, "which then inspired others in other countries to do the same. See Pythag Kurniati, »Bertemu Kapolri, Polisi Jambi yang Nyanyikan Lagu Jiayou Wuhan Ditawari Sekolah Perwira, Kompas, March 8, 2020, https:// regional.kompas.com/read/2020/03/08/13III27I/bertemu-kapolri-polisi-jambiyang-nyanyikan-lagu-jiayou-wuhan-ditawari; Elsa Emiria Leba, "Semangat Be- 
not necessarily able to completely erase the logic of "traditional « authority based on distrust with other parties.

In conclusion, it seems no exaggeration that the world today is faced with two choices, namely the discursive authority offered by Engels or the "traditional « authority model based on the Westphalian logic of territorialism that wants to place the state as the highest holder of control. The choice of "traditional " authority-which is still the choice of many countries today-does not provide a meaningful solution for humanity. The number of coronavirus patients globally is not decreasing but continues to grow in an increasingly extraordinary number. Not to mention the application of this kind of "traditional " authority, which has the potential to strengthen the proliferation of post-truth narratives globally, because to strengthen the positions, territorialism often requires justification from post-truth narratives. This, for example, can be witnessed in the US, which continues to develop the idea of a »Chinese virus« conspiracy under Donald Trump's leadership. ${ }^{\mathrm{I52}}$ The development of post-truth narratives, in turn, complicates the situation, in which the US has become the non-Asian region most severely affected by the coronavirus. ${ }^{153}$ This negative development means that the logic of territorialism that is trying to be

lum Padam, Wuhan Jiayou!«Kompas, February I, 2020, https://kompas.id/baca/ internasional/2020/o2/oI/semangat-belum-padam-wuhan-jiayou/; Tresno Setiadi, "Kisah Mahasiswa di Wuhan Saat Virus Corona Merebak, Teriak Jjiayou dari Balik Jendela, Kompas, February 17, 2020, https://regional.kompas.com/ $\mathrm{read} / 2020 / 02 / \mathrm{I} 7 / \mathrm{I} 703398 \mathrm{I} /$ kisah-mahasiswa-di-wuhan-saat-virus-corona-mere bak-teriak-jiayou-dari-balik?page=all.

I52 Sabrina Tavernise and Richard A. Oppel, Jr., "Spit On, Yelled At, Attacked: Chinese-Americans Fear for Their Safety, "The New York Times, March 23, 2020, https://www.nytimes.com/2020/03/23/us/chinese-coronavirus-racist-attacks. html; BBC, "Coronavirus: Trump Attacks `China-Centric WHO Over Global Pandemic, «BBC, April 8, 2020, https://www.bbc.com/news/world-us-canada-522 I3439.

I53 Nicole Chavez, Jason Hanna and Christina Maxouris, "US Coronavirus Cases Reach more than IOI,Ooo as Reported Deaths Hit New Daily High, “CNN, March 28, 2020, https:/edition.cnn.com/2020/03/27/health/us-coronavirus-fri day/index.html. 
maintained and even strengthened by post-truth narratives is leading to an increasingly devastating humanitarian crisis.

Global barbarism seems to be the right term to refer to the current global tendency in dealing with the coronavirus outbreak. Yet, at the same time, world leaders such as German Chancellor Angela Merkel have appealed for stronger global cooperation to face the coronavirus. ${ }^{154}$ But it seems that such appeals are mere rhetoric without any real action as long as the logic of »traditional " authority is still entrenched in the minds of world leaders. Some netizens responded to Merkel's speech by posting images of burning European Union flags (especially in Italy). ${ }^{155}$ The action illustrates the low public confidence in Merkel's rhetoric, especially among Italian citizens, who have suffered from one of the most severe outbreaks among EU countries.

Engels's idea about authority is a reasonable choice to fill the gap between the rhetoric of cooperation that is being discussed by world leaders and the policies adopted by these leaders. At present, humanity does not need authority, which results in a dualism between rhetoric and action. Humanity needs an authority that does not discriminate between one country and another, between one class and another, or between one civilization and another. Humans need a form of authority that can unite them as one human species. Not bound by boundaries that are confirmed by the old conception of authority. This new conception of a discursive authority that can unite humanity in the big idea as an endangered species needs to be developed. The Engelsian concept (enriched by Bakunin's ideas) is an alternative offer that needs to be developed primarily by the academic world in the hope that global efforts against the coronavirus outbreak

I54 Eszter Zalan, »Merkel: Virus Is Biggest Challenge in EU History, « Euobserver, April 7, 2020, https://euobserver.com/coronavirus/I48003; Ayhan Simsek, „Merkel: Coronavirus Biggest Challenge in EU’s History, «Anadolu Agency, April 6, 2020, https:/www.aa.com.tr/en/europe/merkel-coronavirus-biggest-challenge-ineu-s-history/I794764.

I55 Katya Adler, "Coronavirus Outbreak Eats into EU Unity, "BBC, April 3, 2020, https://www.bbc.com/news/world-europe-52135816. 
will not move increasingly towards barbarism or, even more severely, humans` extinction as a species on earth.

\section{Works Cited}

Adler, Katya. "Coronavirus outbreak eats into EU unity.« BBC, April 3, 2020. https://www.bbc.com/news/world-europe-52135816.

Angus, Ian. »Two accounts of Engels's revolutionary life." Socialist Voice, August 24, 2009.

Aratani, Lauren. "'Coughing while Asians: living in fear as racism feeds off coronavirus panic." The Guardian, March 24, 2020. https://www.theguardian. $\mathrm{com} / \mathrm{world} / 2020 / \mathrm{mar} / 24 /$ coronavirus-us-asian-americans-racism.

Araujo, Saulo de Freitas. »Truth, Half-Truth, and Post-Truth: Lessons from William James." Journal of Constructivist Psychology [online] (February 2020). https://doi.org/I0.I080/10720537.2020.1727390.

Areddy, James T. "Amid Coronavirus, the World Closes Its Doors to China: iI Feel So Isolated«". The Wall Street Journal, February I8, 2020. https:// www.wsj.com/articles/amid-coronavirus-the-world-closes-its-doors-tochina-i-feel-so-isolated-II5820608II.

Avineri, Shlomo. Karl Marx: Philosophy and Revolution. New Haven: Yale University Press, 2019.

Bakunin, Mikhail. "What is Authority?« The Marxists Internet Archive, 1999. https://www.marxists.org/reference/archive/bakunin/works/various/ authrty.htm.

Baradat, Leon P. Political Ideologies: Their Origins and Impact. Abingdon: Routledge, 2016.

BBC. "Coronavirus: Trump attacks, China-centric WHO over global pandemic.«BBC, April 8, 2020. https://www.bbc.com/news/world-us-canada52213439 .

—. "Li Wenliang: Coronavirus death of Wuhan doctor sparks anger." $B B C$, February 7, 2020. https://www.bbc.com/news/world-asia-china-5I40980I.

- " China coronavirus: Misinformation spreads online about origin and scale.« $B B C$, January 30, 2020. https://www.bbc.com/news/blogs-trend ing-51271037. 
—. "Virus corona: Tips terlindung dari Covid-ı9 dan mencegah penyebaran sesuai petunjuk WHO.«BBC, April 2, 2020. https://www.bbc.com/in donesia/dunia-52127080.

Bergman, Jay. The French Revolutionary Tradition in Russian and Soviet Politics, Political Thought, and Culture. Oxford: Oxford University Press, 2019.

Bieber, Florian. "Authoritarianism in the Time of the Coronavirus."Foreign Policy, March 30, 2020. https://foreignpolicy.com/2020/03/30/authori tarianism-coronavirus-lockdown-pandemic-populism/.

Blackledge, Paul. Friedrich Engels and Modern Social and Political Theory. Albany: State University of New York Press, 2019.

Boer, Roland. Stalin: From Theology to the Philosophy of Socialism in Power. Singapore: Springer, 2017.

Brenkert, George G. Political Freedom. London: Routledge, I991.

Budd, Lucy and Stephen Ison. "Air travel restrictions won't protect us from the coronavirus." The Jakarta Post, February I0, 2020. https://www.the jakartapost.com/travel/2020/02/Io/air-travel-restrictions-wont-protectus-from-the-coronavirus.html.

Bulbeck, Chilla. Re-orienting Western Feminisms: Women's Diversity in a Postcolonial World. Cambridge: Cambridge University Press, 1998.

Carthaus, Anna. "Yuval Noah Harari on COVID-ig: 'The biggest danger is not the virus itself « «DW, April 22, 2020. https://www.dw.com/en/virusitself-is-not-the-biggest-danger-says-yuval-noah-harari/a-53195552.

Carver, Terrell. Engels: A Very Short Introduction. Oxford: Oxford University Press, 2003.

-. Friedrich Engels: His Life and Thought. New York: St. Martin's Press, I990.

Chavez, Nicole, Jason Hanna, and Christina Maxouris. »US coronavirus cases reach more than IOI, OOO as reported deaths hit new daily high."CNN, March 28, 2020. https://edition.cnn.com/2020/03/27/health/us-coronavirus-friday/index.html.

Clarke, Michael E. Xinjiang and China's Rise in Central Asia-A History. Abingdon: Routledge, 20II.

Clarke, Simon. Marx, Marginalism and Modern Sociology: From Adam Smith to Max Weber. Aldershot: Macmillan Academic, 199I.

Cosentino, Gabriele. Social Media and the Post-Truth World Order. Cham: Springer, 2020.

De George, Richard T. "Anarchism and Authority." Nomos I9 (1978): 9I-IIO.

Ehrlich, Stanislaw. Pluralism On and Off Course. Oxford: Pergamon Press, 1982. 
Engels, Frederick. "On Authority." In The Marx-Engels Reader, edited by Robert C. Tucker. New York: W. W. Norton \& Company, Inc., 1978.

—. "Versus the Anarchists."In The Marx-Engels Reader, edited by Robert C. Tucker. New York: W. W. Norton \& Company, Inc., 1978.

Evans, Michael. Karl Marx. London: Routledge, 2004.

Farrow, Robert and Rolin Moe. »Rethinking the role of the academy: cognitive authority in the age of post-truth." Teaching in Higher Education 24, no. 3 (2019): 272-287.

Feigan. "Marx's ,Dictatorship of the Proletariat"«. Contemporary Chinese Thought 46, no. 2 (2015): 22-36.

Fetscher, Iring. "Karl Marx on Human Nature." In Karl Marx's Economics: Critical Assessments, edited by John Cunningham Wood. London: Routledge, 1998.

Fischer, Frank. »Knowledge politics and post-truth in climate denial: on the social construction of alternative facts." Critical Policy Studies I3, no. 2 (2019): $133-152$.

Fuchs, Christian. "Dallas Smythe Today-The Audience Commodity, the Digital Labour Debate, Marxist Political Economy and Critical Theory. Prolegomena to a Digital Labour Theory of Value." In Marx and the Political Economy of the Media, edited by Christian Fuchs and Vincent Mosco. Leiden: Brill, 2016.

—. Digital Labour and Karl Marx. New York: Routledge, 2014.

Fuller, Steve. Post-Truth: Knowledge As A Power Game. London: Anthem Press, 2018.

Goodwin, Barbara. Using Political Ideas. Chichester: John Wiley \& Sons, Ltd, 2007.

Harari, Yuval Noah. »In the Battle Against Coronavirus, Humanity Lacks Leadership. «Time, March I5, 2020. https://time.com/5803225/yuval-noahharari-coronavirus-humanity-leadership/.

—. »Yuval Noah Harari: the world after coronavirus. « Financial Times, March 20, 2020. https://www.ft.com/content/19d90308-6858-Irea-a3c9-Ife6fedc ca75.

Hart, Paul 't and Karen Tindall. »From 'market correction so 'global catastrophes: framing the economic downturn." In Framing the Global Economic Downturn: Crisis Rhetoric and the Politics of Recessions, edited by Paul 't Hart and Karen Tindall. Canberra: ANU E Press, 2009. 
Harvey, David. "Anti-Capitalist Politics in the Time of COVID-I9." Jacobin, March 20, 2020. https://jacobinmag.com/2020/03/david-harvey-corona virus-political-economy-disruptions.

Henderson, William Otto. The Life of Friedrich Engels Volume I. London: Frank Cass, I976.

-. The Life of Friedrich Engels Volume II. London: Routledge, 1976.

Higgins-Dunn, Noah. "Travel restrictions >irrelevant if coronavirus becomes a pandemic, top US health official says.« $C N B C$, February 26, 2020. https:/www.cnbc.com/2020/02/26/fauci-travel-restrictions-irrelevantif-coronavirus-becomes-a-pandemic.html.

Hindess, Barry. "Socialism, Communism, Anarchism."In Edinburgh Companion to the History of Democracy, edited by Benjamin Isakhan and Stephen Stockwell. Edinburgh: Edinburgh University Press, 2012.

Holman, Christopher. Politics as Radical Creation: Herbert Marcuse and Hannah Arendt on Political Performativity. Toronto: University of Toronto Press, 20I3.

Holton, R. J. The Transition from Feudalism to Capitalism. New York: St. Martin's Press, 1985.

Honeywell, Carissa. A British Anarchist Tradition: Herbert Read, Alex Comfort and Colin Ward. New York: Continuum, $201 \mathrm{.}$

Horsthemke, Kai. "\#FFactsMustFall??-education in a post-truth, post-truthful world." Ethics and Education I2, no. 3 (2017): 273-288.

Howard, Michael Charles and John Edward King. A History of Marxian Economics, Volume I: I883-I929. Princeton, NJ: Princeton University Press, 1989.

Hudis, Peter. Marx's Concept of the Alternative to Capitalism. Leiden: Brill, 2012.

Hunt, Tristram. Marx's General: The Revolutionary Life of Friedrich Engels. New York: Holt Paperbacks, 2009.

Jacques, Martin. "Marx’s keeper.« The Guardian, May 2, 2009. https://www. theguardian.com/books/2009/may/o2/frock-coated-engels-hunt.

Johnson, Elliott, David Walker, and Daniel Gray. Historical Dictionary of Marxism. Lanham: Rowman \& Littlefield, 2014.

Johnson, Martin Phillip. The Paradise of Association: Political Culture and Popular Organizations in Paris Commune of I87I. Ann Arbor: University of Michigan Press, 1996. 
Josephs, Leslie. "China grows isolated as airlines cancel more than 50, 000 flights amid coronavirus epidemic." $C N B C$, February 6, 2020. https:// www.cnbc.com/2020/02/o6/coronavirus-china-becomes-increasinglyisolated-as-airlines-pull-out.html.

Jun, Nathan. "Anarchism and Just War Theory." In Comparative Just War Theory: An Introduction to International Perspectives, edited by Luis Cordeiro-Rodrigues and Danny Singh. Lanham: Rowman \& Littlefield, 2020.

Kaur, Harmeet. "Forget social distancing. The WHO prefers we call it 'physical distancing، because social connections are more important than ever." CNN, April I8, 2020. https://edition.cnn.com/2020/04/I5/world/ social-distancing-language-change-trnd/index.html.

Krishna, Rachael. »This company is based in Shanghai, not Wuhan." Full Fact, January 30, 2020. https://fullfact.org/online/wuhan-resident-evil-corona virus/.

Kurniati, Pythag. "Bertemu Kapolri, Polisi Jambi yang Nyanyikan Lagu Jiayou Wuhan Ditawari Sekolah Perwira." Kompas, March 8, 2020. https:// regional.kompas.com/read/2020/03/08/13III27i/bertemu-kapolri-polisijambi-yang-nyanyikan-lagu-jiayou-wuhan-ditawari.

Lamb, Peter. Marx and Engels's Communist Manifesto. London: Bloomsbury, 2015 .

Larsson, Paula. "Anti-Asian racism during coronavirus: How the language of disease produces hate and violence." The Conversation, March 3I, 2020. https://theconversation.com/anti-asian-racism-during-coronavirushow-the-language-of-disease-produces-hate-and-violence-I34496.

Lau, Stuart and Owen Churchill. "Xi Jinping urges sstronger international cooperation and quick action to fight coronavirus pandemic and stave off global recession." South China Morning Post, March 26, 2020. https:// www.scmp.com/news/china/politics/article/3077174/xi-jinping-urgesstronger-international-cooperation-and-quick.

Leba, Elsa Emiria. »Semangat Belum Padam, Wuhan Jiayou!« Kompas, February I, 2020. https://kompas.id/baca/internasional/2020/o2/or/semangatbelum-padam-wuhan-jiayou/.

Levine, Norman. »Hegelian Continuities in Marx.« Critique 37, no. 3 (2009): 345-370.

Li, Huaiyin. "Rewriting Modern Chinese History in the Reform Era: Changing Narratives and Perspectives in Chinese Historiography. « In Marxist Historiographies: A Global Perspective, edited by Q. Edward Wang and Georg G. Iggers. Abingdon: Routledge, 2016. 
Li, Lea. "Police, public clash as border reopens between coronavirus epicentre Hubei and Jiangxi province." South China Morning Post, March 29, 2020. https://www.scmp.com/video/china/3077466/police-public-clashborder-reopens-between-coronavirus-epicentre-hubei-and.

Lister, Tim, Sebastian Shukla, and Fanny Bobille. »Coronavirus sparks a 'war for masks` as accusations fly." CNN, April 3, 2020. https://edition.cnn. $\mathrm{com} / 2020 / 04 / 03 /$ europe/coronavirus-masks-war-intl/index.html.

Lovell, David W. From Marx to Lenin: An Evaluation of Marx's Responsibility for Soviet Authoritarianism. Cambridge: Cambridge University Press, 1984.

Löwy, Michael. »Marx, Engels, and Ecology.« Capitalism Nature Socialism 28, no. 2 (2017): IO-2I.

Ma, Josephine and Jun Mai. »Death of coronavirus doctor Li Wenliang becomes catalyst for ffreedom of speech demands in China."South China Morning Post, February 7, 2020. https://www.scmp.com/news/china/politics/ article/3049606/coronavirus-doctors-death-becomes-catalyst-freedomspeech.

Macdonald, Bradley J. Performing Marx: Contemporary Negotiations of a Living Tradition. Albany: State University of New York Press, 2006.

Macguire, Eoghan. "Anti-Asian hate continues to spread online amid COVID-I9 pandemic." Al Jazeera, April 5, 2020. https://www.aljazeera. $\mathrm{com} /$ news/2020/04/anti-asian-hate-continues-spread-online-covid-I9pandemic-2004050630I5286.html.

Magnusson, Lars and Bo Stråth. A Brief History of Political Economy: Tales of Marx, Keynes and Hayek. Cheltenham: Edward Elgar, 2016.

Makowski, Emily. "Theory that Coronavirus Escaped from a Lab Lacks Evidence." The Scientist, March 5, 2020. https://www.the-scientist.com/newsopinion/theory-that-coronavirus-escaped-from-a-lab-lacks-evidence67229.

Marshall, Peter. Demanding the Impossible: A History of Anarchism. Oakland: PM Press, 2010.

Martusewicz, Rebecca A. "All this Boundless Multitude: Rereading Mikahail Bakunin for EcoJustice Education."Educational Studies 48, no. I (2OI2): I-4.

McClelland, J.S. A History of Western Political Thought. London: Routledge, 1996.

McLaughlin, Paul. Anarchism and Authority: A Philosophical Introduction to Classical Anarchism. Aldershot: Ashgate, 2007. 
-. Mikhail Bakunin: The Philosophical Basis of His Theory of Anarchism. New York: Algora Publishing, 2002.

Messer-Kruse, Timothy. The Haymarket Conspiracy: Transatlantic Anarchist Networks. Chicago: University of Illinois Press, 2012.

Morrow, John. History of Western Political Thought. London: Red Globe Press, 2019.

Moseley, Fred and Tony Smith. »Introduction."In Marx's Capital and Hegel's Logic: A Reexamination, edited by Fred Moseley and Tony Smith. Leiden: Brill, 2014 .

Muhammadiyah. "MCCC Denpasar Bagikan Iooo Masker Kepada Warga Kota Denpasar." Muhammadiyah, April ıо, 2020. http://www.muham madiyah.or.id/id/news-I8793-detail-mccc-denpasar-bagikan-Iooomasker-kepada-warga-kota-denpasar.html.

Nashr, Jamal A. »Tegal Lockdown karena Corona, Wali Kota: Tak Ditegur Mendagri.«Tempo, April 3, 2020. https://nasional.tempo.co/read/1327529/ tegal-lockdown-karena-corona-wali-kota-tak-ditegur-mendagri.

Newman, Saul. From Bakunin to Lacan: Anti-authoritarianism and the Dislocation of Power. Lanham: Lexington Books, 200I.

Ollman, Bertell. Alienation: Marx's Conception of Man in Capitalist Society. London: Cambridge University Press, 1971.

Pavon-Cuellar, David. Marxism and Psychoanalysis: In or against Psychology? Abingdon: Routledge, 2017.

Pernicone, Nunzio. Italian Anarchism, I864-1892. Princeton, NJ: Princeton University Press, 1993.

Phoak, Kung. "Stop prejudice, the novel coronavirus has no race." The Jakarta Post, February 22, 2020. https://www.thejakartapost.com/academia/2020/ 02/22/stop-prejudice-the-novel-coronavirus-has-no-race.html.

Pilliang, Yasraf Amir. »Virus De-Globalisasi.«Kompas, March 30, 2020. https:// kompas.id/baca/opini/2020/03/30/virus-de-globalisasi/.

Pillinger, Mara. »Virus Travel Bans Are Inevitable But Ineffective. $F P$, February 23,2020 . https://foreignpolicy.com/2020/O2/23/virus-travel-bansare-inevitable-but-ineffective/.

Portmess, Lisa. »Post-Truth: Marcuse and New Form of Social Control.«In America's Post-Truth Phenomenon: When Feelings and Opinions Trump Facts and Evidence, edited by C. G. Prado. Santa Barbara: Praeger, 2018.

Prew, Paul, Tomás Rotta, Tony Smith, and Matt Vidal. "The enduring Relevance of Karl Marx." In The Oxford Handbook of Karl Marx, edited by 
Tomás Rotta, Tony Smith, Matt Vidal, and Paul Prew. New York: Oxford University Press, 20I9.

Quammen, David. "We Made the Coronavirus Epidemic." The New York Times, January 28, 2020. https:/www.nytimes.com/2020/or/28/opinion/ coronavirus-china.html.

Raustiala, Kal. Does the Constitution Follow the Flag? The Evolution of Territoriality in American Law. Oxford: Oxford University Press, 2009.

Remley, William L. Jean-Paul Sartre's Anarchist Philosophy. London: Bloomsbury Academic, 2018.

Rezneck, Samuel. "The Political and Social Theory of Michael Bakunin." The American Political Science Review 2I, no. 2 (I927): 270-296.

Roberts, William Clare. Marx's Inferno: The Political Theory of Capital. Princeton, NJ: Princeton University Press, 2017.

Rothschild, Joyce, and J. Allen Whitt. The Cooperative Workplace: Potentials and Dilemmas of Organisational Democracy and Participation. Cambridge: Cambridge University Press, 1989.

Sánchez Bermúdez, José Manuel. The Neoliberal Pattern of Domination: Capital's Reign in Decline. Leiden: Brill, 2012.

Sargent, Lyman Tower. "Mikhail Bakunin (1814-76)." In Encyclopedia of Nineteenth-century Thought, edited by Gregory Claeys. Abingdon: Routledge, 2005 .

Saros, Daniel E. Information Technology and Socialist Construction: The End of Capital and the Transition to Socialism. Abingdon: Routledge, 2014.

Sawer, Marian. Marxism and the Question of the Asiatic Mode of Production. The Hague: Martinus Nijhoff, 1977.

Schwartz, Joseph M. The Permanence of the Political: A Democratic Critique of the Radical Impulse to Transcend Politics. Princeton, NJ: Princeton University Press, I995.

Setiadi, Tresno. „Kisah Mahasiswa di Wuhan Saat Virus Corona Merebak, Teriak "Jiayou« dari Balik Jendela."Kompas, February I7, 2020. https:// regional.kompas.com/read/2020/02/17/1703398I/kisah-mahasiswa-diwuhan-saat-virus-corona-merebak-teriak-jiayou-dari-balik? page=all.

Shantz, Jeff. Constructive Anarchy: Building Infrastructures of Resistance. Farnham: Ashgate, 2010.

Shantz, Jeffrey and Dana M. Williams. Anarchy and Society: Reflections on Anarchist Sociology. Leiden: Brill, 2013. 
Shiva, Vandana. "Ecological Reflections on the Coronavirus." Medium, March 23, 2020. https://medium.com/post-growth-institute/ecologicalreflections-on-the-coronavirus-93d 5obbfegdb.

Simsek, Ayhan. "Merkel: Coronavirus biggest challenge in EU's history." Anadolu Agency, April 6, 2020. https://www.aa.com.tr/en/europe/merkelcoronavirus-biggest-challenge-in-eu-s-history/1794764.

Singer, Peter. Marx: A Very Short Introduction. Oxford: Oxford University Press, 2000.

Solis, Marie. "Coronavirus Is the Perfect Disaster for 'Disaster Capitalism «". Vice, March 13, 2020. https://www.vice.com/en_uk/article/5dmqyk/naomiklein-interview-on-coronavirus-and-disaster-capitalism-shock-doctrine.

Stellino, Molly. "Fact check: Did the coronavirus originate in a Chinese laboratory?« USA Today, March 22, 2020. https://www.usatoday.com/ story/news/factcheck/2020/03/2I/fact-check-did-coronavirus-originatechinese-laboratory/28811500oi/.

Sukirno, Ahmad. »Komunitas Difabel Boyolali Bikin Masker untuk Warga Miskin.«rri.co.id, April 8, 2020. http://rri.co.id/post/berita/816848/daerah/ komunitas_difabel_boyolali_bikin_masker_untuk_warga_miskin.html.

Suryajaya, Martin. "Membayangkan Ekonomi Dunia Setelah Korona Atau Cerita tentang Dua Virus. «MartinSuryajaya.com, March 30, 2020. https:// www.martinsuryajaya.com/post/membayangkan-ekonomi-duniasetelah-korona.

Syambudi, Irwan. "Lockdown Mandiri ala Jogja: Ditolak Pemerintah, Diinginkan Warga.«Tirto, March 27, 2020. https://tirto.id/lockdown-mandiriala-jogja-ditolak-pemerintah-diinginkan-warga-eHzo.

Syawaludin, Makhfud. "NU Kabupaten Pasuruan Segera Bagikan 5o Ribu Masker Kain.«NU Online, April II, 2020. https://www.nu.or.id/post/read/ II8950/nu-kabupaten-pasuruan-segera-bagikan-50-ribu-masker-kain.

Taş, Hakkı. »The I5 July abortive coup and post-truth politics in Turkey.» Southeast European and Black Sea Studies I8, no. I (2018): I-I9.

Tavernise, Sabrina and Richard A. Oppel, Jr. "Spit On, Yelled At, Attacked: Chinese-Americans Fear for Their Safety." The New York Times, March 23, 2020. https://www.nytimes.com/2020/03/23/us/chinese-coronavirus-racistattacks.html.

The Anarchist FAQ Editorial Collective. "An Anarchist FAQ (09/17)." Accessed April I, 2020. https://theanarchistlibrary.org/library/the-anarchistfaq-editorial-collective-an-anarchist-faq-09-17.pdf. 
The Jakarta Post. „COVID-I9: Regions start locking down as govt works on regulation." The Jakarta Post, March 28, 2020. https://www.thejakarta post.com/news/2020/03/28/covid-I9-regions-start-locking-down-asgovt-works-on-regulation.html.

The UNESCO Courier. "Yuval Noah Harari: 'Every crisis is also an opportunity«. Accessed April 30, 2020. https://en.unesco.org/courier/newsviews-online/yuval-noah-harari-every-crisis-also-opportunity.

Thomas, Paul. Karl Marx and the Anarchists. Abingdon: Routledge, 2010.

Tisdall, Simon. "Covid-I9 is exposing the frailty in autocrats and democrats alike." The Guardian, March I5, 2020. https://www.theguardian.com/ commentisfree/2020/mar/I5/covid-I9-exposing-frailties-autocrats-demo crats-alike-trump-xi-eu-un.

Tsang, Yuki. "'Shoot them dead : Philippine President Duterte warns coronavirus lockdown violators. "South China Morning Post, April 2, 2020. https:// www.scmp.com/video/coronavirus/3078165/shoot-them-dead-philip pine-president-duterte-warns-coronavirus-lockdown.

Voegelin, Eric. From Enlightenment to Revolution. Durham: Duke University Press, I975.

Ward, Colin. Anarchism: A Very Short Introduction. Oxford: Oxford University Press, 2004.

Whitworth, Andrew. Information Obesity. Oxford: Chandos Publishing, 2009.

Wilde, Lawrence. Global Solidarity. Edinburgh: Edinburgh University Press, 2013.

Willsher, Kim, Julian Borger, and Oliver Holmes. „US accused of 'modern piracy، after diversion of masks meant for Europe." The Guardian, April 4, 2020. https://www.theguardian.com/world/2020/apr/o3/ mask-wars-coronavirus-outbidding-demand.

Wilson, Scott. "Pre-truth, Post-truth and the Present: Jacques Lacan and the Real Horror of Contemporary Knowledge." In Post-Truth and the Mediation of Reality: New Conjunctures, edited by Rosemary Overell and Brett Nicholls. Cham: Springer, 2020.

Woods, Emma. "Science Policy in a Post-Truth World."In Risk and Uncertainty in a Post-Truth Society, edited by Sander van der Linden and Ragnar E. Löfstedt. Abingdon: Routledge, 2019.

Yang, Huan, Peng Bin, and Alex Jingwei He. "Opinions from the epicenter: an online survey of university students in Wuhan amidst the COVID-I9 outbreak."Journal of Chinese Governance 5, no. 2 (2020): 234-248. 
Yeung, Jessie. "A global coronavirus: Travel bans, face masks, and fear."CNN, February 27, 2020. https:/edition.cnn.com/2020/02/27/world/gallery/ coronavirus-prevention/index.html.

Yu, Jianxing. "Confronting and Governing the Public Health Emergency.«Journal of Chinese Governance 5, no. 2 (2020): 137-139.

Yuki. »The semantical issue behind Engels's "On Authority « and how it relates to modern day anarchism." The Anarchist Library, July I2, 2019. https:// theanarchistlibrary.org/library/yuki-the-semantical-issue-behind-engelson-authority-and-how-it-relates-to-modern-day-anarchism\#fnI.

Zalan, Eszter. »Merkel: Virus is biggest challenge in EU history." Euobserver, April 7, 2020. https://euobserver.com/coronavirus/148003.

Zizek, Slavoj. »Barbarism with a Human Face.« Welt, March 19, 2020. https:// www.welt.de/kultur/literarischewelt/article206829259/Slavoj-Zizek-onCorona-Barbarism-with-a-Human-Face.html. 


\title{
Engels as Course Reading in the 21st Century History Classroom
}

\author{
Alexander Maxwell
}

This chapter examines Friedrich Engels's Condition of the Working Class in England (1845) ${ }^{\mathrm{I}}$ as a course reading for first-year university students. Its narrative is essentially autobiographical. I describe my personal motives to the text when I first thought to assign it in a "Modern Europe« survey course, student reactions, and how student reactions affected subsequent iterations of the first-year survey. As it happens, my students, mostly millennials, responded more favorably to the text than I had expected. Their enthusiasm ultimately inspired me to reevaluate Engels's continued relevance in the 2ist century.

An autobiographical narrative, perhaps, should begin with an autobiographical sketch. I was born in Los Angeles, spent most of my high school years in Southern California, and did my undergraduate degree at the University of California, Davis. For this degree, I spent two years as an exchange student in Germany. I found life in Central Europe congenial. While in Germany, I studied Czech and after graduating moved to Prague to teach English as a Second Language (ESL). I have since lived, worked or studied in several Central European towns, including Bratislava, Budapest, Bucharest, and Erfurt. When I did my history Ph.D, I wrote my thesis on Slovak history. After finishing my doctorate, I found short-term jobs in Wales and Nevada, and eventually landed a permanent position at Victoria University of Wellington, New Zealand. I am happily

I Friedrich Engels, Die Lage der arbeitenden Klasse in England (Leipzig: Otto Wigand, I845); first English translation by Florence Kelley Wyschnewetzky, The Condition of the Working Class in England in I844 (New York: John W. Lovell, I887). 
settled in New Zealand, but when I feel homesick, I feel homesick for Central Europe.

Neither my adolescence in Southern California nor my undergraduate education provided any particular emphasis on the works of Karl Marx or Friedrich Engels. I was assigned some Marx to read in an excellent undergraduate course called »European Intellectual History, « but my strongest memory of reading Marx as an undergraduate is a metaphor comparing economic progress to "that hideous, pagan idol who would not drink the nectar but from the skulls of the slain. ${ }^{2}$ At I8, I found Marx's prose pleasingly dramatic. As far as I remember, I did not read any Engels as an undergraduate.

Nor did my formative experiences in the ruins of the Soviet Empire encourage a serious study of Marxism. On the contrary: conversations I had in the former Eastern bloc after the fall of the Berlin Wall encouraged a contemptuous attitude. I treated the failure of the Soviet system as self-evident, and the collapse of the Soviet system as a boon to humanity. During the early I990s, I was not alone treating the Soviet Union's failure as a definitive repudiation of Marxism. My atheism repelled me from American conservatism and I usually took leftist positions on cultural issues like gay rights, but as a young man I accepted market economics, regularly read The Economist, and basically approved of how Tony Blair changed the British Labour party.

My graduate training, furthermore, did not lead me to the Marxist classics. I specialized in the origins of nationalism. The inth century may be the century in which Engels lived, but most East-Central European historiographies also remember it as the era of so-called "national awakening. " I wrote my master's thesis on national awakening in North Macedonia, my doctoral thesis on national awakening in Slovakia, my second book on clothing and national awakening,

2 Karl Marx, "The Future Results of British Rule in India, New-York Daily Tribune, August 8, 1853, cited in Karl Marx and Friedrich Engels, Collected Works (New York: International Publishers, 1979), 222. 
and my third book on national awakening in Hungary. ${ }^{3}$ have also published several works on nationalism theory. ${ }^{4}$ The nationalist ideologies and nationalist activism that interest me tend to come from the middle classes, they do not reflect the struggles of workers or proletarians. Nationalism, as I study it, belongs to intellectual and cultural history: it is rather removed from the social or economic history that interested Marx and Engels.

Scholars influenced by the thought of Marx and Engels have admittedly made several outstanding contributions to nationalism theory. Austrian Social Democratic politician and Marxist theorist Otto Bauer (I88I-1938) wrote an excellent overview of how nationalist politics developed in Habsburg Austria. ${ }^{5}$ Bauer particularly influenced the

3 Alexander Maxwell, Choosing Slovakia: Slavic Hungary, the Czech Language and Unintended Nationalism (London: I. B. Tauris, 2009); Alexander Maxwell, Patriots Against Fashion: Clothing and Nationalism in Europe's Age of Revolutions (London: Palgrave, 20I4); Alexander Maxwell, Everyday Nationalism in Hungary (Berlin: De Gruyter Oldenbourg, 2019).

4 Alexander Maxwell, "Primordialism for Scholars Who Ought to Know Better: Anthony D. Smith's Critique of Modernization Theory, "Nationalities Papers (published online March 2020), DOI: https://doi.org/IO.IOI7/nps.2019.93; Alexander Maxwell and Molly Turner, "Nationalists Rejecting Statehood: Three Case Studies from Wales, Catalonia, and Slovakia,"Nations and Nationalism, (published online December 20I9), DOI: IO.IIII/nana.I2577; Alexander Maxwell, ")Supplicant Nationalism ‘ in Slovakia and Wales: Polyethnic Rights During the Nineteenth Century, "Central Europe I6, no. I (2018): 29-50; Alexander Maxwell, "Nationalism as Classification: Suggestions for Reformulating Nationalism Research, « Nationalities Papers 46, no. 4 (2018): 539-555; Alexander Maxwell, "Nationalism and Sexuality, " in The Wiley Blackwell Encyclopedia of Gender and Sexuality Studies, ed. Nancy Naples (Oxford: Wiley Blackwell, 2016), vol. 4, I74I-I744; Alexander Maxwell, "Typologies and Phase Theories in Nationalism Studies: Hroch's A-B-C Schema as a Basis for Comparative Terminology," Nationalities Papers 38, no. 6 (2010): 865-880; Alexander Maxwell, "Multiple Nationalism: National Concepts in 19th Century Hungary and Benedict Anderson's ,Imagined Communities`, Nationalism and Ethnic Politics II, no. 3 (2005): $385-4$ I4.

5 Otto Bauer, Die Nationalitätenfrage und die Sozialdemokratie (Vienna: Ignaz Brand, 1907); available in English as The Question of Nationalities and Social Democracy (Minneapolis: University of Minnesota Press, 2000). 
Czech scholar Miroslav Hroch, ${ }^{6}$ author of the influential Social Preconditions of National Revival in Europe, the first work I read in graduate school. ${ }^{7}$ I was ultimately more impressed by the British Marxist historian Benedict Anderson (1936-2015), whose Imagined Communities has become a classic in the field. ${ }^{8}$ The influential historian Eric Hobsbawm (1917-2012) also wrote from a Marxist perspective. ${ }^{9}$ These scholars persuaded me that nationalism arises from social transformations that are not really captured by the phrase "industrial revolution," but can, for want of a better term, be summarized as "modernization." Yet if Marxist nationalism scholars influenced my understanding of how nationalism arises, they neither inspired me to read Marx and Engels nor much influenced my political stances. I found their work interesting despite rather than because of their Marxism.

When I started designing undergraduate course syllabi, in short, I had no special desire to assign Engels, or indeed any Marxist classics. American conservatives often express suspicion of "Marxist professors, « as John Wilson documented in his analysis of »the conservative attack on higher education. 10 $^{\text {10 }}$ While I would certainly have failed any conservative purity test, I doubt anybody actually claiming to be a Marxist would acknowledge me as espousing any flavor of Marxism.

My first chance to teach the modern Europe survey came in 2006. I won a one-year temporary teaching fellowship at the University of

6 Miroslav Hroch, "Learning from Small Nations, Interview, "New Left Review 58 (2009): 43 .

7 Miroslav Hroch, Die Vorkämpfer der nationalen Bewegung bei den kleinen Völkern Europas: Eine vergleichende Analyse zur gesellschaftlichen Schichtung der patriotischen Gruppen (Prague: Charles University, 1968); available in English as Social Preconditions of National Revival in Europe: A Comparative Analysis of the Social Composition of Patriotic Groups Among the Smaller European Nations (Cambridge: Cambridge University Press, 1985).

8 Benedict Anderson, Imagined Communities: Reflections on the Origin and Spread of Nationalism (London: Verson, 1983).

9 Eric Hobsbawm, Nations and Nationalism since 1780: Programme, Myth, Reality (Cambridge: Cambridge University Press, 1990).

Io John Wilson, The Myth of Political Correctness: The Conservative Attack on Higher Education (Durham, NC: Duke University Press, I995), IO-II. 
Nevada, Reno. The main theme of the course, as I taught it, was the rise of nationalist politics. Skeptical of textbooks but encouraged to use one, I chose Mark Kishlansky's Sources of the West: Readings in Western Civilization, an anthology of bite-sized excerpts from various primary sources. I felt some moral pressure to select readings from Kishlansky's textbook wherever possible so that students would get value for their textbook purchase. The course contained fourteen weeks; I gave two lectures each week. In week 8, I discussed Marxism in a grab-bag lecture that also covered Darwin, secularization, and suffragism. For that week, I assigned as course reading Kishlansky's excerpt from Condition of the Working Class in England. ${ }^{\text {I }}$

Several considerations led me to assign Engels, rather than any other sources found in Kishlansky. I started from the pedagogical assumption that students in Nevada might struggle to understand the appeal of socialism to historical actors. Given my own politics, I was hardly hoping that my course lectures and course readings would convert students to Marxist politics, but hoped to persuade students, some of whom I assumed would be strongly anti-Communist, that Marxism, socialism, and communism arose in response to pressing social problems. Kishlansky also offers an excerpt from the Communist Manifesto, ${ }^{\mathrm{I2}}$ but Engels's detail-oriented description of urban squalor seemed more likely to help conservative or unworldly middle-class American students appreciate the suffering caused by the industrial revolution.

I felt some trepidation about how the class would respond to Engels. Teaching in a state that had just helped re-elect George W. Bush, I worried that some conservative students might refuse on principle to

II Friedrich Engels, "The Condition of the Working Class in England (I845), « excerpt in Sources of the West: Readings in Western Civilization, vol. 2, eds. Mark Kishlansky, Patrick Geary and Patricia O’Brien (New York: Longman: 2006), reading IO3.

I2 Karl Marx and Friedrich Engels, "The Communist Manifesto, " excerpt in: Sources of the West: Readings in Western Civilization, vol. 2, eds. Mark Kishlansky, Patrick Geary and Patricia O’Brien (New York: Longman: 2006), reading II2. 
read anything by a Communist icon. I also feared that Engels might strike them as dreary. So, for my 2006 course, I assigned two other course readings to accompany Engels: Kishlansky's excerpt from Beatrice Webb's Women and the Factory Acts (1896), and a short excerpt from Coventry Patemore's poem "Angel of the House" (I854). ${ }^{13}$ The Webb text illustrates how socialist activists tried to improve the lives of working class women. Patemore's ode to bourgeois domesticity, I hoped, would strikingly contrast with working-class concerns. Viewing working class suffering through the lens of gender would also speak to the feminist themes of the lecture, and perhaps the poem, which I thought fascinating, would compensate for a course reading I personally had not found particularly interesting.

My 2006 students in Nevada did not respond to these course readings as I anticipated. Patemore's poem left them wholly cold, and they did not want to discuss any gender issues. Instead, they wanted to discuss Engels! They immediately understood and appreciated precarity as a social problem, they reacted with fascination to Engels's description of working-class squalor. One student decided to change the topic of his research essay so as to study Engels more carefully. I had wholly misjudged student reactions.

I remembered student enthusiasm for Engels when designing another modern Europe survey after my arrival in New Zealand. In 2008, shortly after joining the faculty of Victoria University of Wellington, a senior colleague and I created lectures for a team-taught course, given over a twelve-week semester. There were two lectures a week, and after the first week, students also attended a weekly »tutorial" (discussion section). I still taught my half of the course as the rise of nationalism, but the different teaching circumstances required

I3 Beatrice Webb, "Women and the Factory Acts (1896) « excerpt in Sources of the West: Readings in Western Civilization, vol. 2, eds. Mark Kishlansky, Patrick Geary and Patricia O’Brien (New York: Longman: 2006), reading I20; »The Angel of the House, " excerpt from Bernie Heidkamp, Genders and Identities in the Poetry of Walt Whitman (1997). Accessed March 25, 2020. https://whitmanarchive. org/archiver/classroom/student_projects/bernie/patmore.html. 
several innovations. In Wellington, for example, faculty routinely compile their own books of readings instead of using a textbook, I thus gained more freedom to choose whatever reading best served my pedagogical aims.

My colleague and I chose to devote the eleven weekly tutorials to the in-depth discussion of primary sources, which encouraged us to find a single text. Kishlansky's brief excerpts would no longer be appropriate: we needed something longer. When selecting readings, my colleague and I both prioritized exposing students to canonical texts, echoing the spirit of a so-called "great books" course. Marxism, socialism, and communism have been important forces in world history and educated people should have some idea what they are about. Engels's The Condition of the Working Class in England surely qualifies as one of the "great books. «So, however, would several works by the even more famous Karl Marx. Browsing anthologies of Marxist classics for a suitable reading, I looked first for something written by Marx.

In the end, however, I again chose Engels's Condition of the Working Class in England. Marx's Capital proved much too long and complex for a first-year modern Europe survey, and I found no suitably self-contained excerpts. I more seriously considered a chapter from the Communist Manifesto. The book as a whole seemed too long for one week's course reading; students who have to read more than 40 pages tend not to be prepared for class discussion, but the individual chapters are about the right length. The opening chapter, "Bourgeois and Proletarians, " nicely outlines the Marxist theory of history. The stirring bit about proletarians having nothing to lose but their chains, however, comes from the end of the final chapter, "Position of the Communists in relation to the various existing Opposition Parties." This last chapter, however, opens by expressing support for the Chartists in England, Agrarian reformers in America, Social Democrats in France, the Radicals in Switzerland, and the I846 uprising in Kraków. I feared first-year students in New Zealand would be overwhelmed if the course reading began with a long list of unfamiliar 
political parties. I remembered how positively students in Nevada had responded to Engels, so I stuck with that.

Since I needed a lengthier reading, I also properly read Engels for the first time. The book proved more engaging than Kishlansky's excerpts had led me to believe. Engels describes hunger, streets, houses, furniture, clothing, and toilets: everything is immediate and concrete. Engels mentions several place names that students in New Zealand do not know, such as Benthal Green and "the famous rookery of St. Giles, $\aleph^{14}$ but the point comes through even if readers are not familiar with English geography. My favourite passage from the whole work occurs in the chapter "the Great Towns, " in which Engels describes a traveler arriving in London by ship. The sight of the Thames packed with tall-masted ships, Engels tells his readers, »is so vast, so impressive, that a man cannot collect himself but is lost in the marvel of England's greatness before he sets foot upon English soil. «" The passage illustrates an enthusiasm for progress I expected students would find surprising, and its eloquence also captured my imagination.

In the end, therefore, my senior colleague and I assigned Engels for tutorial discussion. The accompanying lecture remained a grab-bag of I9th-century social movements, covering socialism alongside secularism, racial "science, " anti-Semitism, and suffragism. I extended the bit on socialism, transcribing key passages from the Communist Manifesto onto PowerPoint slides. My colleague and I did not teach the tutorials ourselves, but indirect feedback from postgraduate student tutors was positive. In New Zealand, as in Nevada, students liked reading Engels.

Ten years later, I am teaching still another first year Modern Europe survey. The course is still team taught, but my senior colleague has left the department and been replaced by a junior colleague. I am still a scholar of nationalism and I still dwell primarily on the rise of nationalism in the course narrative overall. Nevertheless, my lectures

I4 Friedrich Engels, Condition of the Working Class in England (Oxford: Oxford University Press, 1993), 4I, 39.

I5 Ibid., 36 . 
now depict socialism as a serious if ultimately unsuccessful alternative to national movements. I still show excerpts from the Communist Manifesto on PowerPoint slides, but in the relevant lecture Marx no longer shares space with secularism or suffragism. I instead depict utopian socialism, Marxism, and anarchism as social consequences of the industrial revolution. The lecture also links more directly with subsequent lectures on 2oth-century communism.

In the meantime, I have also acquired a deeper understanding of the history of socialism. Preparing lectures for a different course, I read biographies of Marx, Vladimir I. Lenin (1870-1924) and Leon Trotsky (1879-1940), which in turn inspired me to broader reading about the First and Second International, as well as the history of anarchism. My deeper understanding in turn informed my first-year lectures. To demonstrate the internationalist scope of the First International, for example, I made a PowerPoint slide depicting on a map the location of active correspondents in the first half of I866; to construct the map I went through the minutes from the First International. ${ }^{16}$

In the most recent version of the syllabus, last taught in 2018 , I have also further expanded the Engels content. As in my 2008 course, students are supposed to discuss the "The Great Towns" in the tutorial meetings for week eight. As in the past, students find the reading engaging, and tutors describe it as one of the more successful tutorials. Students like reading Engels! The 2018 course, furthermore, requires students to buy a cheap paperback edition of Condition of the Working Class in England and write a short essay about it. Students have two options for their essay on Engels. Both options require students to analyze his text in light of another course reading, chosen so as to minimize the chance that an online essay mill will have an essay ready to download.

I6 The General Council of the First International, I864-1866, The London Conference I865, Minutes (Moscow: Progress, 1964). 
The first essay option asks students whether the political system described in the 1789 "Declaration of the Rights of Man and Citizen, « a founding constitutional document from the French Revolution, provides the necessary means to address the injustices Engels outlines. Students generally answer in the negative: they do not think that a "democratic " government is sufficient to curb the excesses of the industrial revolution. Our students mostly come from the comfortable middle classes; I am not sure whether they realize that their skepticism implies a radical rejection of parliamentary democracy.

The second essay option asks students to compare the living conditions Engels describes with those depicted in Slavenka Drakulićs How We Survived Communism and Even Laughed, an extremely readable memoir of socialist Yugoslavia. ${ }^{17}$ Student opinion on this question is more evenly divided: some emphasize differences, others stress similarities. Several students compare Drakulićs description of shoddy Yugoslav housing to their own student accommodation in Wellington. (Rental housing in New Zealand is shockingly poor overall). ${ }^{18}$

Over the course of my career, therefore, Engels has steadily grown in importance. Initially assigned as only in the form of a brief excerpt, Engels's Condition of the Working Class in England has fifteen years later become a staple course reading in my "Modern Europe« survey. As a course reading, the text has proved much more successful than I had expected. Indeed, it may be the only course reading I assign in which students get more out of the reading than I do. Indeed, looking back, my own inability to predict the appeal of Engels may be the most interesting feature of the story.

I7 Slavenka Drakulić, "On Doing Laundry, « in How We Survived Communism and even Laughed (New York: Vintage, 1987), 43-54.

I8 Philippa Howden-Chapman et al., "Tackling Cold Housing and Fuel Poverty in New Zealand: A Review of Policies, Research, and Health Impacts, "Energy Policy 49 (20I2): I34-I42; Elinor Chisholm and Kimberley O'Sullivan, „Using Twitter to Explore (Un)Healthy Housing: Learning from the \# Characterbuildings Campaign in New Zealand, "International Journal of Environmental Research and Public Health I4, no. II (2017): I424. 
My inability to anticipate the appeal of Engels could have any number of causes, but a difference in social origins seems unlikely. I resemble most of my students in that I enjoy white privilege in a settler society. Polynesian students attend Victoria University of Wellington, and students of color attended the University of Nevada at Reno, but such students have not been strongly represented in the first year "Modern Europe« survey. The students in my courses probably boast from more diverse class backgrounds, but my downwardly mobile middle-class upbringing has not created any noticeable cultural differences between me and my students.

My students, however, are much more concerned about their own economic prospects than I had been at their age. I grew up in the final years of the Keynesian consensus. As a child, I did not know what I wanted to be "when I grew up, « but I feared boring, meaningless work more than unemployment and poverty. Nor did I question whether I could afford university, I assumed a way would somehow be found. My confidence was not entirely misplaced. My father paid the loan I took out for my undergraduate degree, and I won fellowships for my graduate study. University history teaching jobs are hard to find and I did not have a proper job until I was thirty-eight years old, but I got one in the end, even if I had to move to a distant country that I had never previously visited. Thanks to some combination of perseverance and good fortune, things worked out for me in the end.

The students I teach, by contrast, are coming of age in an era of neoliberalism, and experience the precarity that neoliberalism implies. Since several authors have ably documented the overall trend toward economic insecurity in recent decades, ${ }^{19}$ I will here consider only the cost of university tuition. I began my undergraduate degree in the

I) Loïc Wacquant, Punishing the Poor: The Neoliberal Government of Social Insecurity (Durham, NC: Duke University Press, 2009); Rob Lambert and Andrew Herod, eds. Neoliberal Capitalism and Precarious Work: Ethnographies of Accommodation and Resistance (Cheltenham, UK: Edward Elgar Publishing, 2016); Sanford Schram, The Return of Ordinary Capitalism: Neoliberalism, Precarity, Occupy (Oxford: Oxford University Press, 20I5). 
1987/8 school year, and taught my first Modern Europe survey in Nevada in 2005/6. During that time, the cost of American university education at a four-year institution, adjusted for inflation, has more than doubled, rising from US\$ 9,223 in $1987 / 8$ to US\$2I,28I in 2005/6 (in constant 2016/7 dollars)..$^{20}$ The situation aspiring students face in New Zealand is not nearly so dire, but the trend is moving in the same direction. In 2000, the median total student debt

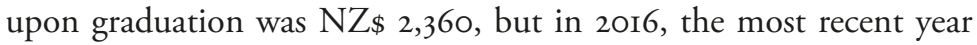
for which figures are available, the median total student debt was $\mathrm{NZ}_{\$}$ I8,650. ${ }^{2 \mathrm{I}}$ The erosion of the welfare state is a global process, affecting both Nevada and New Zealand.

Declining economic opportunity has led to a general divergence in political opinions. Economic precarity, Ruth Milkman argues, has contributed to "a new political generation " more open to socialist thinking. ${ }^{22}$ A 2019 Gallup survey found, for example, that $49 \%$ of Millennials have a positive view of "Socialism, " as compared to $39 \%$ of my own generation, and $32 \%$ of Baby Boomers. The same poll found millenials relatively disenchanted with "Capitalism. $\ll^{23}$ This generational shift has caused anxiety among existing elites: the Washington Post, for example, published an alarmist editorial under the headline "Millennials have a higher opinion of socialism than

20 "Table 330.I0: Average Undergraduate Tuition and Fees and Room and Board Rates ... Selected Years, 1963-64 through 2016-17, "National Center for Education Statistics (2017). Accessed January 24, 2020. https://nces.ed.gov/programs/ digest/dı7/tables/dtı7_330.Io.asp.

2I "Median Annual Amount Borrowed and Median Student Loan Leaving Balance," data table available at "Affordability of Tertiary Education to Students, « Ministry of Education, New Zealand Government (2020). Accessed January 24, 2020. https:/www.educationcounts.govt.nz/statistics/indicators/main/family-andcommunity-engagement/1999.

22 Ruth Milkman, "A New Political Generation: Millennials and the Post-2008 Wave of Protest, "American Sociological Review 82, no. I (2017): I-3I.

23 Lydia Saad, "Socialism as Popular as Capitalism Among Young Adults in U.S.," Gallup, October I-13, 20I9. Accessed January 24, 2020. https://news.gallup.com/ poll/268766/socialism-popular-capitalism-among-young-adults.aspx. 


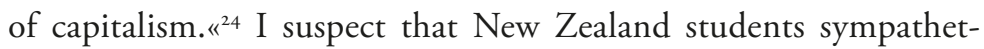
ic to socialism, if confronted with the Washington Post's anxieties, would respond much as New Zealand Green MP Chlöe Swarbrick responded to a parliamentary heckler: „OK Boomer. ${ }^{25}$

Perhaps, then, my students like reading Engels because they find him relevant to their lives. Engels shines a spotlight on precarity, and that speaks to their anxieties about their own futures. He also provides a scathing and timeless critique of establishment hypocrisy, for example, in his memorable denunciation of those "charitable out of self-interest, ${ }^{26}{ }^{6}$ and I think students respond to that, as well. Most importantly, he frames inequality and poverty as injustices deserving remedy.

One could, of course, over-state Engels's relevance to millennial concerns. Millennials are supposedly the first generation of »digital natives, " and since Engels did not anticipate the internet, he has little to say about its dilemmas. Millennials are also concerned about the environmental crisis. I struggle to see Engels as a pioneering environmentalist, even if, as Ted Benton rightly observed, "Engels makes links between the environmental conditions and health of the industrial working population on the one hand, and their working conditions and class relations on the other. ${ }^{27}$ Even Engels's analysis of industrial capitalism, furthermore, provides few answers to Lenin's famous question "What is to be done? (28 $^{8}$ Engels calls for dramatic changes to the structure of society without divisively spelling out

24 Catherine Rampell, "Millennials Have a Higher Opinion of Socialism than of Capitalism, «Washington Post, February 6, 2016.

25 Dan Satherley, ")OK Boomer: World Reacts to NZ Politician Chloe Swarbrick's Use of Meme in Parliament, «Newshub, November 7, 2019. Accessed January 24, 2020. https://www.newshub.co.nz/home/politics/2019/II/ok-boomer-worldreacts-to-nz-politician-chloe-swarbrick-s-use-of-meme-in-parliament.html.

26 Engels, Condition of the Working Class, 283-284.

27 Ted Benton, „Engels and the Politics of Nature, « in Engels Today, ed. Christopher Arthur (London: Palgrave Macmillan, 1996), 68.

28 Vladimir I. Lenin, Chto dělat?? Nabolévshie voprosy nashego dvizhenije (Stuttgart: Dietz, 1902); see also "What is to be Done? « in Collected Works (Moscow: Foreign Languages Publishing House, 196I), vol. 5, 347-530. 
what exactly those changes ought to be. Identifying problems is easier than finding solutions. Students presumably would not respond as well to the book if it confronted them with concrete policy proposals.

Students nevertheless engage so deeply with Engels that I have in turn found myself drawn to more closely his ideas in my middle age. If a relatively privileged youth explains why I was unable to predict Engels's appeal when I started teaching, reading Engels with multiple cohorts of undergraduate students has helped me see the power and relevance of his thought in the 2Ist century. My economic opinions have also shifted leftwards: I no longer read The Economist, even if I still do not make a very good Marxist. The work of Engels, mediated through the appreciative eyes of my undergraduate students, played a role in shaping my political views.

\section{Works Cited}

"Affordability of Tertiary Education to Students, « Ministry of Education, New Zealand Government (2020). Accessed January 24, 2020. https://www. educationcounts.govt.nz/statistics/indicators/main/family-and-commu nity-engagement/1999.

Anderson, Benedict. Imagined Communities: Reflections on the Origin and Spread of Nationalism. London: Verson, 1983.

Bauer, Otto. Die Nationalitätenfrage und die Sozialdemokratie. Vienna: Ignaz Brand, 1907.

-. The Question of Nationalities and Social Democracy. Minneapolis: University of Minnesota Press, 2000.

Benton, Ted. »Engels and the Politics of Nature.« In Engels Today, ed. Christopher Arthur, 67-93. London: Palgrave Macmillan, 1996.

Chisholm, Elinor and Kimberley O’Sullivan. "Using Twitter to Explore (Un) Healthy Housing: Learning from the \# Characterbuildings Campaign in New Zealand." International Journal of Environmental Research and Public Health I4, no. II (2017): I424.

Drakulić, Slavenka. How We Survived Communism and even Laughed. New York: Vintage, 1987. 
Engels, Friedrich. Die Lage der arbeitenden Klasse in England. Leipzig: Otto Wigand, 1844 .

- The Condition of the Working Class in England in I844, transl. by Florence Kelley Wyschnewetzky. New York: John W. Lovell, I887.

-. Condition of the Working Class in England. Oxford: Oxford University Press, 1993.

Hobsbawm, Eric. Nations and Nationalism since 1780: Programme, Myth, Reality. Cambridge: Cambridge University Press, 1990.

Howden-Chapman, Philippa et al., »Tackling Cold Housing and Fuel Poverty in New Zealand: A Review of Policies, Research, and Health Impacts." Energy Policy 49 (2012): 134-I42

Hroch, Miroslav. Die Vorkämpfer der nationalen Bewegung bei den kleinen Völkern Europas: Eine vergleichende Analyse zur gesellschaftlichen Schichtung der patriotischen Gruppen. Prague: Charles University, 1968.

—. "Learning from Small Nations, Interview." New Left Review 58 (2009): $4 \mathrm{I}-59$.

-. Social Preconditions of National Revival in Europe: A Comparative Analysis of the Social Composition of Patriotic Groups Among the Smaller European Nations. Cambridge: Cambridge University Press, 1985.

Kishlansky, Mark, Patrick Geary and Patricia O'Brien Sources of the West: Readings in Western Civilization, vol. 2. New York: Longman: 2006.

Lambert, Rob and Andrew Herod, eds. Neoliberal Capitalism and Precarious Work: Ethnographies of Accommodation and Resistance. Cheltenham, UK: Edward Elgar Publishing, 2016.

Lenin, Vladimir I. Chto dělat?? Nabolèvshie voprosy nashego dvizhenije. Stuttgart: Dietz, 1902.

—. Collected Works, vol. 5. Moscow: Foreign Languages Publishing House, I96I.

Marx, Karl and Friedrich Engels. Collected Works. New York: International Publishers, 1979.

Maxwell, Alexander. Choosing Slovakia: Slavic Hungary, the Czech Language and Unintended Nationalism. London: I. B. Tauris, 2009.

-. Everyday Nationalism in Hungary. Berlin: De Gruyter Oldenbourg, 2019.

-. "Nationalism and Sexuality." in The Wiley Blackwell Encyclopedia of Gender and Sexuality Studies, ed. Nancy Naples (Oxford: Wiley Blackwell, 20I6), vol. 4, I74I-1744. 
—. Multiple Nationalism: National Concepts in 19th Century Hungary and Benedict Anderson's ,Imagined Communitiesı" Nationalism and Ethnic Politics II, no. 3 (2005): 385-4I4.

-. "Nationalism as Classification: Suggestions for Reformulating Nationalism Research."Nationalities Papers 46, no. 4 (2018): 539-555.

— and Molly Turner, »Nationalists Rejecting Statehood: Three Case Studies from Wales, Catalonia, and Slovakia."Nations and Nationalism, (published online December 2019), DOI: IO.IIII/nana.I2577

-. Patriots Against Fashion: Clothing and Nationalism in Europe's Age of Revolutions. London: Palgrave, 20I4.

—. "Primordialism for Scholars Who Ought to Know Better: Anthony D. Smith's Critique of Modernization Theory." Nationalities Papers, (published online March 2020), DOI: https://doi.org/IO.IOI7/nps.2019.93.

-. "Supplicant Nationalism During the Nineteenth Century." Central Europe 16, no. I (2018): 29-50.

- " Typologies and Phase Theories in Nationalism Studies: Hroch's A-B-C Schema as a Basis for Comparative Terminology."Nationalities Papers 38 , no. 6 (20I0): $865-88$ o.

Milkman, Ruth. »A New Political Generation: Millennials and the Post-2008 Wave of Protest." American Sociological Review 82, no. I (20I7): I-3I.

Rampell, Catherine. "Millennials Have a Higher Opinion of Socialism than of Capitalism." Washington Post, February 6, 2016.

Saad, Lydia. "Socialism as Popular as Capitalism Among Young Adults in U.S.« Gallup, October I-13, 2019. Accessed January 24, 2020. https:// news.gallup.com/poll/268766/socialism-popular-capitalism-amongyoung-adults.aspx.

Satherley, Dan. »OK Boomer: World Reacts to NZ Politician Chloe Swarbrick's Use of Meme in Parliament.« Newshub, November 7, 2019. Accessed January 24, 2020. https://www.newshub.co.nz/home/politics/2019/ II/ok-boomer-world-reacts-to-nz-politician-chloe-swarbrick-s-use-ofmeme-in-parliament.html.

Schram, Sanford. The Return of Ordinary Capitalism: Neoliberalism, Precarity, Occupy. Oxford: Oxford University Press, 2015.

"Table 330.IO: Average Undergraduate Tuition and Fees and Room and Board Rates ... Selected Years, 1963-64 through 2016-17, "National Center for Education Statistics (2017). Accessed January 24, 2020. https://nces. ed.gov/programs/digest/dı7/tables/dtI7_330.IO.asp. 
The General Council of the First International, 1864-1866, The London Conference 1865, Minutes. Moscow: Progress, 1964.

Wacquant, Loïc. Punishing the Poor: The Neoliberal Government of Social Insecurity. Durham, NC: Duke University Press, 2009.

Wilson, John. The Myth of Political Correctness: The Conservative Attack on Higher Education. Durham, NC: Duke University Press, 1995. 



\section{Contributors}

Riccardo Altieri is PhD student at the University of Potsdam, Germany.

Nuruddin Al Akbar is a PhD student at the Department of Politics and Government, Faculty of Social and Political Sciences, Universitas Gadjah Mada, Indonesia.

Vitor Bartoletti Sartori is Professor at the Federal Universiy of Minas Gerais, Brazil.

Jia Feng is Associate Professor at the School of History and Culture, Shandong University, Jinan, China.

Frank Jacob is Professor of Global History at Nord Universitet, Norway.

David Pavón-Cuéllar is Professor of Marxism, Social Psychology and Psychoanalysis at the State University of Michoacán (Universidad Michoacana de San Nicolás de Hidalgo, Morelia, Mexico).

Maria Rosário de Carvalho is a Professor at Universidade Federal da Bahia, in Brazil, and a research productivity fellow at the National Council for Scientific and Technological Development (CNPq).

Gottfried Schweiger works at the Centre for Ethics and Poverty Research of the University of Salzburg. His interests lie primarily in 
the field of political philosophy on issues of poverty, childhood, migration and justice. He runs the popular German philosophy blog www.praefaktisch.de and is co-editor of the open access Zeitschrift für Praktische Philosophie.

Renildo Souza is Professor of Political Economy at the Federal University of Bahia, Brazil.

Vincent Streichbahn is PhD student at Halle University, Germany.

Gilmar Visoni-Alonzo is Professor of History at CUNY's Queensborough Community College, New York, USA.

Alexander Maxwell is senior lecturer at Victoria University of Wellington, New Zealand, where he also runs the Antipodean East European Study Group. He has published widely on East European history, nationalism theory, and history pedagogy.

Henrique Wellen is Professor at the Federal University of Rio Grande do Norte, Brazil. 